\title{
Tongues and Trees: \\ Towards a Green Pentecostal Pneumatology
}

\author{
by \\ AARON JASON SWOBODA
}

A thesis submitted to the University of Birmingham for the degree of DOCTOR OF PHILOSOPHY

School of Philosophy, Theology

and Religion

College of Arts and Law

The University of Birmingham

July 2011 


\begin{abstract}
This thesis develops a Pentecostal ecotheology by utilizing key pneumatological themes that emerge from the Pentecostal tradition. It examines and utilizes the salient Pentecostal and Charismatic voices that have stimulated ecotheology in the Pentecostal tradition and situates them within the broader context of Christian ecumenical ecotheologies (Roman Catholic, Orthodox, Protestant, and Ecofeminist). These Pentecostal expressions are placed in dialogue with the particular ecological pneumatologies of Denis Edwards (Roman Catholic), Mark Wallace (Protestant), and Sallie McFague (Ecofeminist). The thesis advances a novel approach to Pentecostal ecotheology through a pneumatology of the Spirit baptized creation, the charismatic creational community, the holistic ecological Spirit, and the eschatological Spirit of ecological mission. Significantly, this thesis is the first substantive contribution to a Pentecostal pneumatological theology of creation with a particular focus on the Pentecostal community and its significance for the broader ecumenical community. Furthermore, it offers a fresh theological approach to imagining and sustaining earth-friendly practice in the twenty-first century Pentecostal church.
\end{abstract}




\section{ACKNOWLEDGMENTS}

Before continuing, some long-standing personal debts must be paid.

Quinn, the most beautiful, loving, and compassionate wife any human could ask for: thank you! I love you endlessly. Your continual willingness to allow me time and space to complete this and other outlandish projects can never be repaid. As we started, let's keep holding hands to glory.

Our unborn child. Thank you for surprising us when you did. Ultimately, you are forcing me to finish this dissertation. If you had never come, I'm unconvinced I'd have ever finished. Mom, Dad, Mike, and Metta. Thanks for being the best sets of parents a kid could ask for this side of heaven. You have provided love, meals, educational funding, gas money, and endless patience. I love each of you dearly.

Theophilus, the church I claim the joy of pastoring. You give me hope.

Dr. Mark Cartledge. You are awesome! No one could ask for a more genuine and honest example to follow in this endeavor. Your encouraging rear-kicking has made me who I am today. And to Joan and Becky, thanks for the curry. Dr. Allan Anderson showed me the green hills just outside Birmingham. Loved getting lost with you. Finally, Dr. Andrew Davies graciously read this thesis in the latter stages and offered the most valuable of comments.

The faculty at George Fox Evangelical Seminary. While continuing to remain in strong fellowship with many Pentecostal academics outside my local context, I weekly teach alongside a community of the most Spirit-led, non-Pentecostal scholars in academia at George Fox. You have made room for me and given much space for me to exist and practice as a young scholar. Thank you to this open-minded, gracious, patient, and loving faculty. In particular, Dr. Mary-Kate Morse and Dr. Dan Brunner have given me personal and academic guidance around every corner and have poured into me a passion for teaching, learning, and Christ-centered education.

Loren Kerns conned me into the academic life, Nate Poetzl instilled in me a love for the Bible, and Steve Overman gave me space to work on this thesis while serving at Eugene Faith Center. Each of you opened my eyes. Thank you. I owe you so much.

To the saints of the faith, both dead and living. As a Christian, a purist objectivism is not something I have right to claim. To deny that my Christian experience has not shaped with certainty everything I think and write is hubris in the highest degree. For, as one once told me, there is no view from nowhere. Thank you to the church for sticking to the notion that has revolutionized my life: the gospel.

Father, Son, and Spirit. You not only gave me fingers to type, but life to live. Soli Deo Gloria. 


\section{TABLE OF CONTENTS}

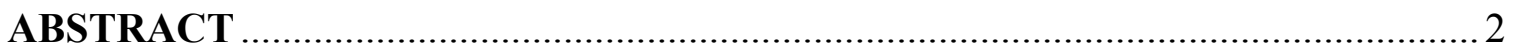



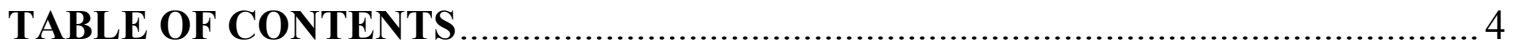

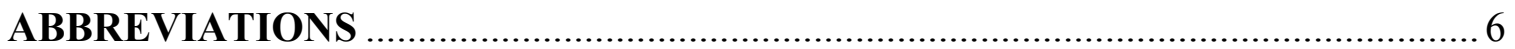

Chapter 1: INTRODUCTION-VOICES IN THE WILDERNESS ........................ 9

1.1 The Ecology and Ecotheology Movements ......................................................... 11

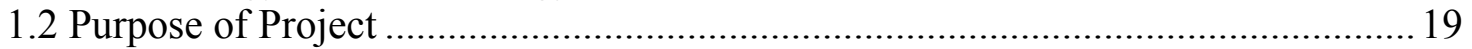

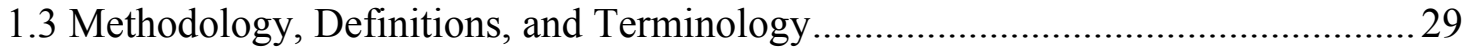

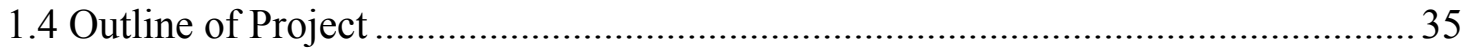

Chapter 2: THE GREEN SCENE_ECOTHEOLOGY IN CONTEXT ……............ 37

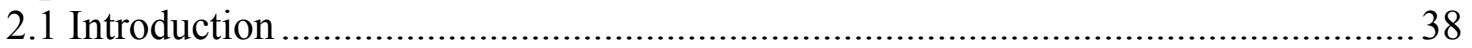



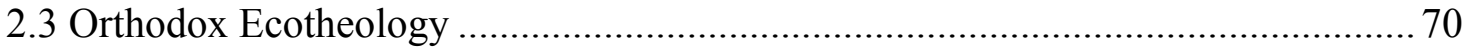

2.4 Protestant Ecotheology ....................................................................................... 76



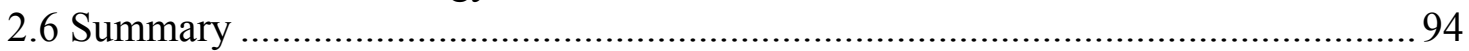

Chapter 3: ECOGLOSSOLALIA-THE TONGUES OF A TWENTY-FIRST



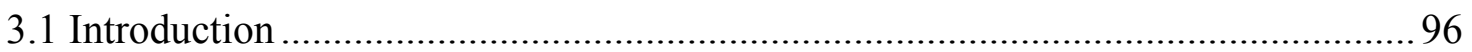

3.2 The Tongues of Twenty-First Century Pentecostal Ecotheology .......................... 104

3.2.1 Charismatic Social Justice.............................................................................. 104

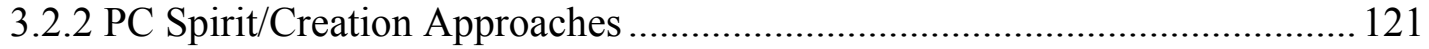

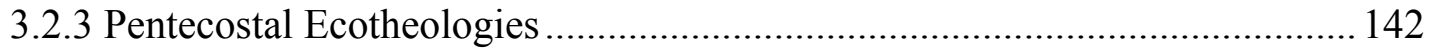



Chapter 4: THE SPIRIT CLIMATE-RECENT ECOPNEUMATOLOGICAL



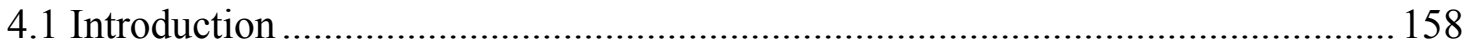

4.2 Denis Edwards's “Biocentric Spirit"................................................................ 160

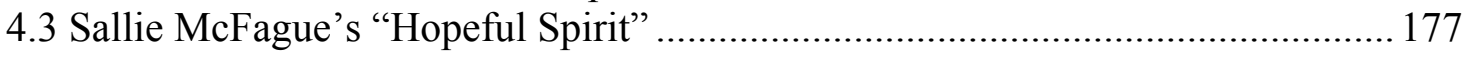

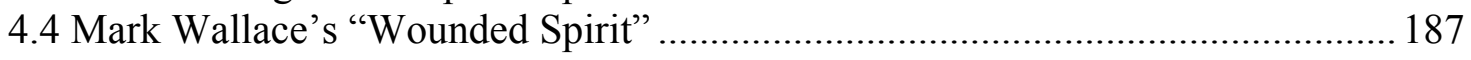

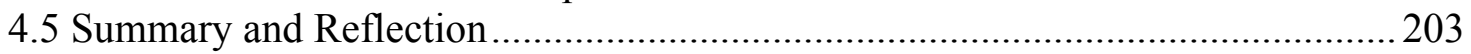

4.5.1 Reflecting on Denis Edwards's "Biocentric Spirit"...................................... 204

4.5.2 Reflecting on Sallie McFague's "Hopeful Spirit".........................................209

4.5.3 Reflecting on Mark Wallace's "Wounded Spirit"............................................2 214

Chapter 5: GEOGRAPHY OF THE SPIRIT-CENTRAL THEMES IN



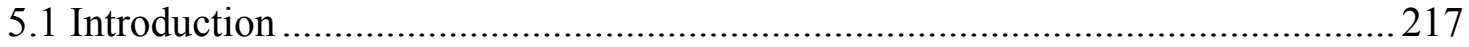

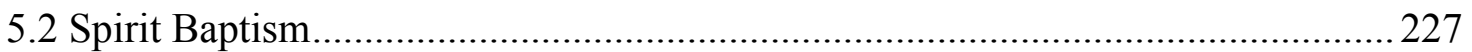

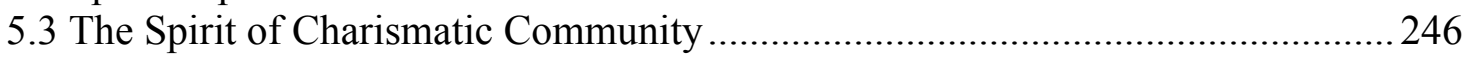


5.4 The Holistic Spirit ...........................................................................................25

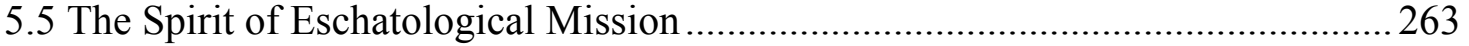

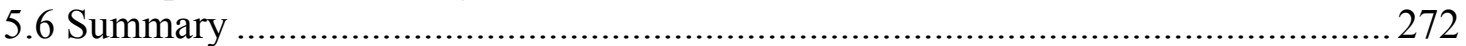

Chapter 6: TONGUES AND TREES-TOWARDS A GREEN PENTECOSTAL



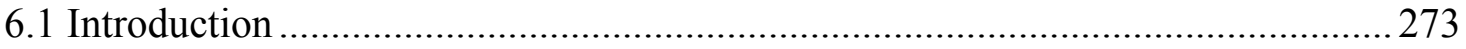

6.2 The Spirit Baptized Creation...........................................................................22

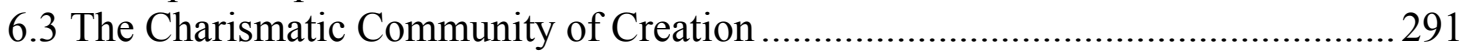

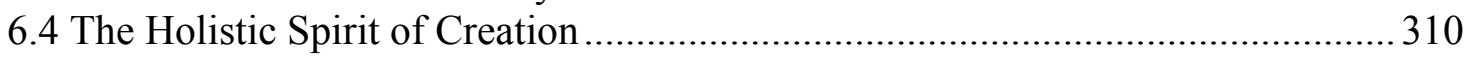

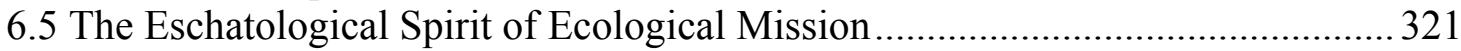

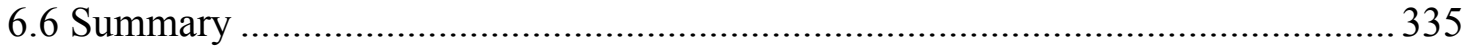

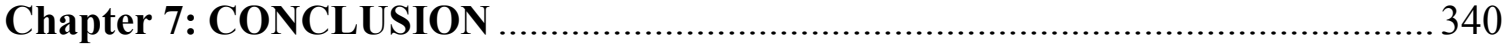

7.1 Summary and Significance of the Research Project ……………….................... 340



7.3 Future Possibilities of a Pentecostal Ecotheology ................................................. 347

7.4 Practical and Ecclesiological Implications of the Research Project .......................351

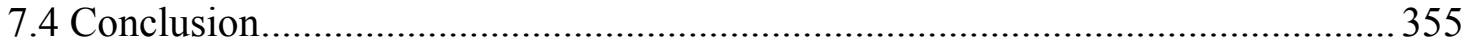






\section{ABBREVIATIONS}

Terminology

$\begin{array}{ll}\text { NAE } & \text { National Association of Evangelicals } \\ \text { NCC } & \text { National Council of Churches } \\ \text { NT } & \text { New Testament } \\ \text { OT } & \text { Old Testament } \\ \text { LXX } & \text { Septuagint } \\ \text { PC } & \text { Pentecostal and Charismatic } \\ \text { RC } & \text { Roman Catholic/Roman Catholicism } \\ \text { WCC } & \text { World Council of Churches } \\ \text { WWC } & \text { World Water Council }\end{array}$

Journals and Texts

$\begin{array}{ll}\text { AJPS } & \begin{array}{l}\text { Asian Journal of Pentecostal Studies } \\ \text { ATR }\end{array} \\ \text { AUSS } & \text { Anglican Theological Review } \\ \text { BibS } & \text { Bibliotheca Sacra } \\ \text { CC } & \text { Christian Century } \\ \text { CRC } & \text { Cross Currents } \\ \text { CT } & \text { Christianity Today } \\ \text { CTNS } & \text { The Bulletin for the Center of Theology and the } \\ \text { CU } & \text { Natural Sciences } \\ \text { DA } & \text { Continuum } \\ \text { DG } & \text { Didaskalia } \\ \text { ECO } & \text { Dialog } \\ \text { EE } & \text { Ecotheology }\end{array}$




$\begin{array}{ll}\text { EPI } & \text { Epiphany } \\ \text { ER } & \text { Ecumenical Review } \\ \text { FT } & \text { First Things } \\ \text { HTR } & \text { Harvard Theological Review } \\ \text { IBMR } & \text { International Bulletin of Missionary Research } \\ \text { IJT } & \text { Indian Journal of Theology } \\ \text { INQ } & \text { Inquiry } \\ \text { INT } & \text { Interpretation } \\ \text { IRM } & \text { International Review of Mission } \\ \text { JAAR } & \text { Journal of the American Academy of Religion } \\ \text { JACT } & \text { Journal of African Christian Thought } \\ \text { JBL } & \text { Journal of Biblical Literature } \\ \text { JEPTA } & \text { Journal of the European Pentecostal Theological } \\ \text { JES } & \text { Association } \\ \text { JETS } & \text { Journal of Ecumenical Studies } \\ \text { JHLT } & \text { Journal of the Evangelical Theological Society } \\ \text { JPT } & \text { Journal of Hispanic/Latino Theology } \\ \text { JPTSup } & \text { Kodern Theology } \\ \text { JR } & \text { Journal of Pentecostal Theology } \\ \text { JSNTSup } & \text { Journal of Pentecostal Theology Supplement Series } \\ \text { JSOTSup } & \text { Journal of Religion } \\ \text { JSSR } & \text { Journal for the Study of the New Testament } \\ \text { KTR } & \text { Supplement Series } \\ \text { Sournal for the Study of the Old Testament }\end{array}$




$\begin{array}{ll}\text { NIDPCM } & \begin{array}{l}\text { New International Dictionary of Pentecostal and } \\ \text { Charismatic Movements }\end{array} \\ \text { OJRS } & \text { Ohio Journal of Religious Studies } \\ \text { PNEUMA } & \text { Journal of the Society for Pentecostal Studies } \\ \text { PSCF } & \text { Perspectives on Science and Christian Faith } \\ \text { PT } & \text { Political Theology } \\ \text { PTH } & \text { Philosophy and Theology } \\ \text { RE } & \text { Religious Education } \\ \text { RL } & \text { Religion in Life } \\ \text { SC } & \text { The Spirit \& Church } \\ \text { SDS } & \text { Soundings } \\ \text { SE } & \text { Studia Evangelica } \\ \text { ST } & \text { Studia Theologica } \\ \text { STM } & \text { Stimulus } \\ \text { SWC } & \text { Studies in World Christianity } \\ \text { TE } & \text { Theologia Evangelica } \\ \text { TH } & \text { Theology } \\ \text { TR } & \text { Transformation } \\ \text { TS } & \text { Theological Studies } \\ \text { TT } & \text { Theology Today } \\ \text { WSH } & \text { Worship } \\ \text { WTJ } & \text { Wesleyan Theological Journal } \\ \text { WW } & \text { Zygon World } \\ \text { ZY } & \end{array}$




\section{Chapter 1}

\section{INTRODUCTION—VOICES IN THE WILDERNESS}

Our perception of the universe is marked by increased complexity. It goes without saying that humankind's comprehension of the nature of the universe has evolved significantly over time. This is particularly the case in the last five centuries. By means of Copernicus (1473-1543), Kepler (1571-1630), and Galileo (1564-1642), we now perceive afresh the expansive grandeur of a galaxy within which we are no longer the center. Isaac Newton (1643-1727) awakened us to gravity and Charles Darwin (1809-1882) forcefully argued that earth's lifespan began nearly four billion years ago, evolving into what we see today. All of these have earnestly portrayed a creation that seems a bit more mysterious, and undeniably more complex, than previously perceived in earlier static models. More recent discoveries have proliferated these shifting paradigms. Edwin Hubble's discovery in 1924 (published in 1929) of an apparent expanding galactic system have led many to suggest a greater possibility both of what has been called the "Big Bang" and, by extension, an expanding universe. ${ }^{1}$ Almost certainly, this spectrum of shifts in perception have added up to massive alterations in cosmological understanding, side-stepping more putative views of the universe.

In the mid-1950s, a number of scientists and cosmologists discovered what they called nucleosynthesis - a novel hypothesis suggesting that all existing cosmic material

\footnotetext{
${ }^{1}$ Cosmologist/physicist Stephen Hawking commented that the discovery of the expanding universe is "one of the great intellectual revolutions of the twentieth century." Stephen Hawking, A Brief History of Time (New York: Bantam, 1988), 39. The "Big Bang" theory was first proposed in 1931 by the Belgian physicist and Roman Catholic priest Georges Lemaitre, contending that if the universe was indeed expanding there must have been a point at which it was all centralized in one place. Lemaitre called this the "primeval atom."
} 
essentially remains recycled material from this "Big Bang" event. ${ }^{2}$ Following Hubble in 1965, Arno Penzias's and Robert Wilson's seminal discovery of expanding background radiation harmonized with Hubble's thesis, further indicating the possibility of a "Big Bang" event and the reality of a rapidly expanding universe. Soon, Einstein's theory of relativity would do little to perpetuate a once safe and static view of the universe. ${ }^{3}$ All the while, many amongst the Christian tradition would continue to reserve questions regarding any (or all) of these recently developed theories. Yet one thing remains clear: human perception of the universe has evolved radically in the last five centuries even if one contends the universe itself has not. Truly, as we discover a seemingly whole new world, late modern ${ }^{4}$ human experience is re-situating itself in the wake of staggering revolutions not only in scientific, cosmological, and theological paradigms. One of these shifts, vital to our current discussion, is of an ecological nature.

\footnotetext{
2 Thanks to Denis Edwards for pointing out this discovery. Denis Edwards, Jesus and the Cosmos (Mahwah: Paulist, 1991), 65-66.

${ }^{3}$ On the significance of Einstein's theory of relativity for scientific and Western understandings of God, see Gregory Ganssle and David Woodruff, eds., God and Time: Essays on the Divine Nature (New York: Oxford University Press, 2002).

4 "Late modern" will be used in contrast to "post modern." Both refer to a set of philosophical tendencies connected to the time following modernism, which is commonly considered to have begun between the 1930s and 1960s. The term "post modernism" is often ascribed to the twentieth-century French philosophers Jean-François Lyotard and Jean Baudrillard. In contrast, we will commonly use the term "late modern" throughout. For an exploration of this contrast, see Robert Neville, Religion in Late Modernity (Albany: State University of New York Press, 2002), 144. For usage of "late modern" within a Pentecostal framework, see F. LeRon Shults, "The Philosophy of Time: The Turn to Futurity in Late Modern Philosophy," ST 61.1 (2007), 47-60; F. LeRon Shults, "Spirit and Spirituality: Philosophical Trends in Late Modern Pneumatology," PNEUMA 30.2 (2008), 271-287.
} 


\subsection{The Ecology and Ecotheology Movements}

What is ecology? Ecology is what Phyllis Tickle calls the study of the "right-here-rightnow. $" 5$ The term is believed to be first coined by the German biologist and naturalist Ernst Haeckel in 1886. This ecological concept derives itself from the Greek notion of a household (oikos), a term earlier utilized by authors of the New Testament (NT). ${ }^{6}$ In regards to the earth's ecosystem, the household (oikos) of the universe is where everything (animate or inanimate) is understood to be related to everything else. Simply put, in the words of G. Tyler Miller, the notion of ecology carries with it the idea that everyone and everything is downwind from everyone and everything else. ${ }^{7}$ On a contemporary level, ecological studies continue to be advancing academic and theoretical fields that explore the enigmatic and interconnected web of organic life, natural process, and by extension, the ecological crisis. Widely, the emergence of ecology has been said to parallel a growing concern that there is something deeply troubling with our tiny earthen corner of the galaxy. Contemporary ecologists and scientists speak-often with

\footnotetext{
${ }^{5}$ Phyllis Tickle, God-Talk in America (New York: Crossroad, 1997), 65. For a similar definition of ecology in regards to religious communities, see Michael Schut, "Coming Home: Economics and Ecology," ATR 91.4 (2009), 581-588.

${ }^{6}$ Haeckel defined ecology as "the totality or pattern of relations between organisms and their environments." For biographical and theoretical sketches of Haeckel's life and thought, see Mario Gregorio, From Here to Eternity: Ernst Haeckel and Scientific Faith, Theologie Und Naturwissenschaft, vol. 3 (Gottingen: Vandenhoeck \& Ruprecht, 2005); Ernst Haeckel, The History of Creation, trans., E. Ray Lankester, vol. 2 (New York: Appleton, 1876); Robert Richards, The Tragic Sense of Life: Ernst Haeckel and the Struggle over Evolutionary Thought (Chicago: University of Chicago, 2008). Most of Haeckel's work can be found online at http://www.gutenberg.org/browse/authors/h\#a2037, (accessed April 7, 2009).

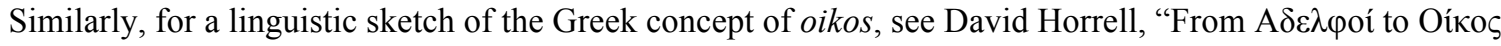
Theou: Social Transformation in Pauline Christianity," JBL 120.2 (2001), 296-299. I find helpful H.

Rolston IIIs definition of ecology as it relates to our cosmological imagination helpful here: being "a logic of the whole that is a home (eco-logos) a logic of the self in relation to the whole." H. Rolston III, "The Bible and Ecology," INT 50 (1996), 16-26.

${ }^{7}$ A theme found throughout G. Tyler Miller, Living in the Environment (Belmont: Wadsworth, 1992).
} 
some degree of disagreement — of an impending crisis. ${ }^{8}$ Evidence corroborates this suspicion illustrating significant changes in the bioatmosphere, presumably as a result of earth's human inhabitants.

The evidence of this crisis is rather telling. For instance, the global average surface temperature has increased $0.74{ }^{\circ} \mathrm{C}\left(1.3^{\circ} \mathrm{F}\right)$ over the last century resulting in the sea level rising approximately $17 \mathrm{~cm}$ over the same period. ${ }^{9}$ Consequentially, polar ice caps are melting at exponential rates resulting in the potential destruction of island life, as in the case of the Maldives. Climate models project additional warming of 1.1 to $6.4{ }^{\circ} \mathrm{C}$ with a sea level swell of 18 to $59 \mathrm{~cm}$ by the end of the twenty-first century. ${ }^{10}$ According to the WCC, 1.1 billion individuals lack safe drinking water, 2.6 billion lack adequate sanitation, 1.8 million die from diarrheal disease (90\% are women and children), and 3,900 children die daily for lack of water or hygiene. ${ }^{11}$ Furthermore, excessive farming due to overburdened population centers has depleted rain forests at alarming speeds, global carbon outputs from factories and industry economies far outweigh the ecosystems' ability to ingest them, and species loss is increasingly commonplace. This is

\footnotetext{
${ }^{8}$ It is unfair to caricature the various scientific perspectives regarding the ecological crisis as unanimously agreeing on all or any points discussed here. There remain significant variances (what we might call "scientific denominations") within the scientific and ecological communities.

${ }^{9}$ Douglas Allen, "Is the Sky Falling: A Brief Introduction to Climate Change Science," in Christians, the Care of Creation, and Global Climate Change, ed. Lindy Scott (Eugene: Pickwick, 2008), 6-23 (11). See also John Houghton, Global Warming: The Complete Briefing (Cambridge: Cambridge University Press, 2004); International Panel on Climate Change, Climate Change 2007: Impacts, Adaptations, and Vulnerability (Cambridge: Cambridge University Press, 2007); Susan Solomon, et. al., eds., Climate Change 2007: The Physical Science Basis: Contributions of Working Group I to the Fourth Assessment Report of the Intergovernmental Panel on Climate Change (Cambridge: Cambridge University Press, 2007). For up to date information regarding climate change evidence, see http://www.ipcc.ch/index.htm, (accessed December 7, 2010).

${ }^{10}$ Allen, "Is the Sky Falling," 11.

${ }^{11}$ Found at www.worldwatercouncil.org/index.php?id=23, (accessed January 4, 2010). Suggested reasons for the decline of water supplies have been from rising population, industrial development, and expansive agricultural growth. United Nations Environment Programme, Global Environmental Outlook 3: Past, Present, and Future Perspectives (London: Earthscan Publications, 2002), 151.
} 
not to mention the economic and cultural consequences which are equally as

burdensome. ${ }^{12}$ All of this, to many ecologists and scientists, points to an impending crisis that must be curbed if the earth's ecosystem will survive as we have come to know it.

Daniel Maguire, on somewhat dire terms, has commented that "if present trends continue, we will not."13

On a popular level, the North American cultural awareness of this ecological crisis proliferated by means of Rachel Carson's watershed Silent Spring in 1962. Carson's works have had a lasting effect on the Western ecological conscience, all of which began primarily as a critique of the perilous usage of pesticides in North American agrarian practices. Silent Spring had such a profound cultural effect that it would eventually lead to both the birth of the environmental movement in North America and a ban on pesticide usage in the United States in $1972 .{ }^{14}$ The question was now on the broader cultural conscience: who is to blame for this newly exposed crisis? ${ }^{15}$

\footnotetext{
${ }^{12}$ On the economic implications of the ecological crisis, see N.H. Stern, The Economics of Climate Change: The Stern Review (Cambridge: Cambridge University Press, 2007). For scientific explorations into the ecological crisis, see Michael Collier and Robert Webb, Floods, Droughts, and Climate Change (Tucson: University of Arizona Press, 2002); Elizabeth Kolbert, Field Notes from a Catastrophe: Man, Nature, and Climate Change (New York: Bloomsbury Press, 2006); K. Lee Lerner and Brenda Lerner, Environmental Issues: Essential Primary Sources (Detroit: Thomson Gale, 2006); W. F. Ruddiman, Plows, Plagues, and Petroleum: How Humans Took Control of Climate (Princeton: Princeton University Press, 2007); Karl Turekian, Global Environmental Change: Past, Present, and Future (Upper Saddle River: Prentice Hall, 1996); Peter Ward, Under a Green Sky: Global Warming, the Mass Extinctions of the Past, and What They Can Tell Us About Our Future (New York: Smithsonian Books, 2008). Calvin DeWitt has further listed seven degradations to God's creation: (1) land conversion and habitat destruction, (2) species extinction, (3) degradation of the land, (4) resource conversion and production of wastes and hazards, (5) global toxification, (6) greenhouse effect and ozone depletion, (7) human and cultural degradation. See his Calvin DeWitt, et. al., Caring for Creation: Responsible Stewardship of God's Handiwork (Grand Rapids: Baker, 1998), esp. chap. 1.

${ }^{13}$ Daniel Maguire, The Moral Core of Judaism and Christianity: Reclaiming the Revolution (Philadelphia: Fortress, 1993), 3, (italics mine).

${ }^{14}$ Rachel Carson, Silent Spring (New York: Houghton, 1962). Carson dedicated Silent Sprint to a personal hero, Albert Schweitzer, who himself had championed a Christian renewed "reverence for life." For a further examination of the importance of Carson's text within the context of the emergence of the
} 
At the height of this cultural stirring, medieval historian Lynn White Jr. delivered

a now-famous lecture the day after Christmas in 1967. White's lecture, entitled "The

Historical Roots of Our Ecological Crisis," placed the ecological "burden of guilt" on

Western Christianity by pointing to its failure in achieving a theological heritage

beneficial for all of nonhuman existence. ${ }^{16}$ White's critique primarily argued that

Western Christianity had invariably wed Western culture to a negligent interpretation of

the biblical command to "subdue the earth" (Gen. 1:28a). ${ }^{17}$ This, and other influences,

ultimately led to sweeping technological advances (e.g., mass production) that

perpetuated a cultural and communal hostility towards nonhuman earth. In its wake,

others began constructing fresh arguments following White's newly established thesis.

environmental movement in the West, see Mark Lytle, The Gentle Subversive: Rachel Carson, Silent Spring, and the Rise of the Environmental Movement (Oxford: Oxford University Press, 2007).

${ }^{15}$ The responses to this question are rather creative and widespread. For example, Eric Zencey has placed blame on higher education, suggesting that the modern pedagogical culture forces academics to move great distances for teaching contracts and positions, thus forcing upon them a forfeiture of husbandry to land and place. Eric Zencey, "The Rootless Professors," in Rooted in the Land: Essays on Community and Place, eds. Wes Jackson and William Vitek (New Haven: Yale University Press, 1996), 15-20.

${ }^{16}$ Lynn White Jr., “The Historical Roots of Our Ecological Crisis,” Science 155 (1967), 1203-07. White's article was originally delivered as a lecture and then published in Science in 1967. White's thesis solicited a great deal of academic discussion, with a number of responses, retorts, and reactions since its original publication. For a brief summary of these responses, see John Bennett, "On Responding to Lynn White: Ecology and Christianity," OJRS 5.1 (1977), 71-77; Paul Djupe and Patrick Hunt, "Beyond the Lynn White Thesis: Congregational Effects on Environmental Concern," JSSR 48.4 (2009), 670-688; David Lodge and Christopher Hamlin, "Beyond Lynn White: Religion, the Contexts of Ecology, and the Flux of Nature," in Religion and the New Ecology (Notre Dame: Notre Dame, 2006), 1-25; Duncan Roper, "The Earth as a 'Garden' for All Creatures: Lynn White Forty Years On," STM 15.4 (2007), 12-20; Paul Santmire, "The Liberation of Nature: Lynn White's Challenge Anew," CC 102.18 (1985), 530-533. Responding to White, theologian Jack Rogers followed and documented the works of theologians in their relation to ecology. Jack Rogers, "Ecological Theology: The Search for an Appropriate Theological Model," in Septuagesimo Anno, (Kampen, Netherlands: Uitgeversmaatschappij, 1973), 180-202. Finally, for an apologetic response against White's argument, see Francis Schaeffer, Pollution and the Death of Man (Wheaton: Crossway Books, 1970). Nearly one year prior to White's proposal, Harvey Cox suggested that Western secularization had led to a desacralization of nature arising from interpretations of the biblical creation story which separated "man" from "nature." Cox remained relatively positive regarding technological advancement in light of perceiving a connection between the two. Harvey Cox, The Secular City: Secularization and Urbanization in Theological Perspective (New York: Macmillan, 1965).

${ }^{17}$ A sweeping study of the pertinent biblical ecological texts is available at David Horrell, The Bible and the Environment: Towards a Critical Ecological Biblical Theology (Oakville: Equinox, 2010). Biblical texts will be drawn from the New International Version (NIV) throughout the text. 
For instance, Arnold Toynbee went so far as to suggest that our ecological predicament had emerged predominately from a Western fidelity to the "rise of monotheism." 18

In this context, "ecological theology," or ecotheology, surfaced as a collective response by Christian communities and theologies to these unprecedented critiques. ${ }^{19}$ Nearly half a century since White's critique, the ecotheological movement has radically diversified. Within this context, some defend Christian ecological practice and its historical, theological, and ecclesial traditions while others sympathetically echo White's critique. ${ }^{20}$ Still other theologians have responded by centering their efforts on scientific discussions where many are engaged in ongoing scientific inquiry. ${ }^{21}$ Others have concentrated on constructing an ecotheology on a biblical or theological level. But the question still lingers for any invested in the conversation: is the earth's ecological crisis, at least in part, a result of a Christian theology in crisis which has failed to offer an adequate ethical paradigm for human responsibility in caring for creation? Whether in affirming or denying these theological challenges, ongoing efforts have been sustained to

\footnotetext{
${ }^{18}$ Arnold Toynbee, "The Religious Background of the Present Environmental Crisis," in Ecology and Religion in History, eds. David Spring and Eileen Spring (New York: Harper and Row, 1974), 137-149. His argument suggests that as monotheism rose as a prominent form of religious life in human communities, worship of nature (i.e. paganism) eventually became marginalized as a sort of competition to strict monotheism. Toynbee's thesis concludes that once nature had been, in essence, "desacralized," monotheists were free to do as they chose with the natural world and abuse it in oppressive ways.

${ }^{19}$ Hereafter I will utilize the term "ecotheology" as a shortened form of "ecological theology." "Ecological theology" is most likely to have been first coined by John Cobb in the mid-twentieth century. It was given a larger platform in a speech by Joseph Spittler in 1961 to the WCC calling for an earthy Christology with attention to a more cosmic soteriology. Later, in 1963, it grew in popularity in the context of the NCCs Faith-Man Nature Group. Thanks for this point in James Livingston and Francis Fiorenza, eds., Modern Christian Thought, vol. 2 (Upper Saddle River: Prentice Hall, 2000), 333.

${ }^{20}$ Wesley-Granberg Michaelson likewise lays a majority of the ecological crisis on the Western church and modern religious systems. Wesley Granberg-Michaelson, Ecology and Life: Accepting Our Environmental Responsibility (Waco: Word Books, 1988).

${ }^{21}$ For instance, I am reminded here of the work of John Polkinghorne, Ian Barbour, Arthur Peacocke, Holmes Rolston, Paul Elbert, and Francis Collins - theologians with science backgrounds who have each offered theological insights from the Christian perspective while continuing in scientific endeavors. Nevertheless, by and large, Christian ecotheology has been constructed by those lacking scientific credentials, basing some (or most) of their work on others scientific findings.
} 
update late modern Western Christian theology in light of these newest comprehensions of the damaged earth by virtue of human, religious, and political ecological irresponsibility. ${ }^{22}$ As we shall see, since White's thesis gained academic and cultural strength, Christian theology has embarked on a widespread undertaking to reenvision a theology of the earth alongside an appropriated effort at an ecological ethic —even if, in some sense, it has been forced to. On a growing level, both within and outside the Christian tradition, many are looking for answers from the Christian community. This is the case both in regards to the role Christianity has played in the ecological crisis and its attempt to alleviate its challenges in a twenty-first century setting.

Yet in efforts to develop a Christian ecotheology in a Western context, some challenges have made themselves clear. First, culturally, Western Christian communities are finding their own traditions too often being paired with consumerist Western individualism and wanton capitalism; both undeniably playing a key role in ecological degradation, especially in the Third World. In this way, ecotheology continues to struggle in finding its own voice within the culture of Western capitalism while at the same time being critical of it. Secondly, there is an eschatological challenge. Christianity has historically been an eschatological movement of people awaiting Christ's parousia. Yet, nearly two thousand years after the emergence of Christianity, its followers have been forced to embrace a more sustainable and long-term ethic that makes room for

\footnotetext{
${ }^{22}$ One such example of this is the constructive theology of Peter Hodgson. Hodgson, in a broader attempt to reinterpret theology in light of oppression and power structures suggests all theology is like sailing a boat. Hodgson solicits that, like any boat, theology must come in for repairs on occasion. Overall, Hodgson's work is a prime example of an ecologically-corrected constructive theology. Peter Hodgson, Winds of the Spirit: A Constructive Christian Theology (Louisville: Westminster John Knox Press, 1994). Similarly, James Nash has attempted to construct a reformation of ecological theology based on a theological/ethical crisis. James Nash, "Toward the Ecological Reformation of Christianity," INT 50.1 (1996), 5-15.
} 
sustainable ecological living. This is because Christ has yet to return as quickly as

Christianity had originally hoped. Thus, ecotheology and ecological practice—-stewarding the land, decrying species loss, recycling, learning how to love God's creation-all imply humanity may be here for a while and must take a greater responsibility in stewarding earth's ecosystem. Another equally tedious challenge is faced in regards to eschatological models that predict an apocalyptic end of the world. These models often logically conclude that if creation will ultimately be destroyed at the eschaton, ecological efforts will be inherently fruitless. Models such as this seemingly prepare the eschaton with an apocalyptic ecological ethic that gives no, or little, regard to earth care. These are clearly powerful challenges. Thus, the situation of our ecological age is forcing Christianity to reenvision the nature of eschatological existence. For ecological practice is an honest acceptance that both God's creation is groaning for liberation all the while Christ has yet to return in eschatological fulfillment. Thus the task of contemporary ecotheology: to embrace a fresh ecological imagination that highlights and harmonizes the distinctive voices of the Christian tradition to construct an ecological ethic that is suitable for our contemporary situation in Christian communities and ecclesial networks. ${ }^{23}$

The challenge, therefore, is developing a theology not centered apologetically but constructively. Yet, what must happen for a constructive ecotheological approach to be produced? As a brief examination of material will reveal, much of the recent Western

\footnotetext{
${ }^{23}$ This present work limits itself to the last thirty-five years. Furthermore, there are a number of imaginative texts illuminating historical ecotheology available to us today even beyond the Christian tradition that cannot be engaged here. For a more in-depth analysis, see Roger Gottlieb, This Sacred Earth: Religion, Nature, Environment, (New York: Routledge, 2004). For an overview of the larger response by religious and ecumenical movements, see Max Oelschlaeger, Caring for Creation: An Ecumenical Approach to the Environmental Crisis (New Haven: Yale University Press, 1994); Mary Tucker and John Grim, Worldviews and Ecology: Religion, Philosophy, and the Environment (Maryknoll: Orbis, 1994).
} 
ecotheological landscape promulgates an apologetic undertone against a prevailing cultural milieu. This is even more so the case in ecotheological paradigms that exist against the critiques leveled by White and Toynbee who seemingly put the entire blame on Christianity. But these apologetic works are ultimately unhelpful. For it is unconvincing that an apologetic stance has produced a constructive praxis-centered response for what is most needed today. One thing remains undisputed: while White and others' contributions may not be entirely accurate in their portrayal of an antiecological Christianity, their forceful critiques have opened anew the need for humility among Christians to seek how best to contribute amidst our current ecological situation. That is to say that White may have overstepped his argument, but Christian theology is better for $i t$. The requisite fruitful dialogues that have sprung from the critiques of White and others have forced upon Christian theology the opportunity to reflect on itself in healthy and constructive ways. As we move forward, what will be needed are more positive constructive efforts with ultimate goals of praxis-oriented ecological repentance, not defeating White and Toynbee.

What is most needed now is a praxis-centered creation theology that equips Christian communities to better care for the earth, which God created and intends to restore and reconcile to himself. Theologians from among every major Christian tradition have attempted this sort of constructive work. For instance, as we shall see in the chapter to follow, in the Roman Catholic (hereafter referred to as RC) tradition, Matthew Fox, Thomas Berry, Teilhard de Chardin, and Karl Rahner have each reframed a robust ecological conversation that has a profound value for developing care for creation in a late modern setting. Similarly, in the Orthodox tradition, the Patriarch Bartholomew and 
Paulos Gregorios are reimagining ecotheology. Protestants, through such theologians as Paul Santmire, Steven Bouma-Prediger, and Jürgen Moltmann, have produced afresh a Protestant green theology. And finally, the ecofeminist advance has readied an ecological response through Sallie McFague, Elizabeth Johnson, and Rosemary Ruether, to name a few. But we seem to be forgetting somebody. What say ye Pentecostals and Charismatics?

\subsection{Purpose of Project}

This thesis is a response to the question: what might a Pentecostal ecotheology actually look like? We will answer this question both for the PC communities and the broader ecumenical community. In scope, this project will argue for an advance of a Pentecostal ecotheology from a pneumatological perspective. This will be filling two major lacunae in Pentecostal and ecumenical theological scholarship: firstly, to stimulate an ecotheology amongst Pentecostal academies and communities. And as such, this theological endeavor for PC theology will serve as a launch pad for further ecotheology as Pentecostal communities continue to grow at the rate of nearly twenty million a year. ${ }^{24}$ Secondly, this project will offer the broader ecumenical and ecological community an inside look at what Pentecostal ecotheology might actually look like for purposes of

\footnotetext{
${ }^{24}$ Harvey Cox, Fire from Heaven: The Rise of Pentecostal Spirituality and the Reshaping of Religion in the Twenty-First Century (Reading: Addison-Wesley, 1995). Cox suggests in this widely received text that Pentecostal spiritualities are a part of the larger undercurrent of spirituality found in indigenous and ecstatic spiritualities worldwide that find rooting in the homo religiosus. He further suggests there are three main trajectories in these spiritualities: ecstatic speech, mystical piety, and millennial fervor. When brought together, these form into what he calls "primal spirituality." For a very helpful engagement of Cox's forceful thesis, see Amos Yong, Discerning the Spirit(S): A Pentecostal-Charismatic Contribution to Christian Theology of Religions, JPTSup, vol. 20 (Sheffield: Sheffield Academic Press, 2000), 17-20.
} 
theological dialogue and clarity. For many outside the Pentecostal world (and for many within), the notion of a Pentecostal ecotheology is perhaps as absurd as a Pentecostal systematic theology or a Charismatic academic. But it is my conviction that Pentecostal theology has a latent ecotheological tradition that very well opens up novel dialogue points for Pentecostalism and the larger Christian community to wrestle with ecological and creational issues. Furthermore, I would like to suggest that a formal Pentecostal ecotheology has significant power to sustain, create, heal, and protect human and nonhuman life on earth, a task entirely possible while perhaps seemingly oxymoronic to those outside the Pentecostal community. ${ }^{25}$

A brief personal anecdote will represent the ongoing quandary for Pentecostal communities as they attempt to develop an ecotheological model. My engagement with Pentecostalism was at best sparse until my later college years. Previous to this, my exposure was little more than a cursory reading of Dennis Covington's enigmatic encounter with Pentecostal snake-handlers in the Appalachian Mountains in his iconic Salvation on Sand Mountain (1995). ${ }^{26}$ To say the least, this was a peculiar yet stimulating introduction to Pentecostalism through the lens of those Pentecostals who could be healed from audaciously drinking poison and handling snakes in faith. Later, as a sophomore in college, I had my initial encounter with a Pentecostal community through an on-campus ministry. In 2005, along with my new wife, I became the college-age pastor at a Foursquare Church that sponsored the college ministry after having just recently begun my work on a graduate degree in Biblical Studies at George Fox Evangelical Seminary at

\footnotetext{
${ }^{25}$ A term borrowed from fellow ecological Pentecostal scholar Matthew Tallman in personal conversation.

${ }^{26}$ Dennis Covington, Salvation on Sand Mountain: Snake Handling and Redemption in Southern Appalachia (New York: Penguin, 1995).
} 
the age of twenty-four. A year into the pastorate, the church had discovered a major environmental risk in its children's building which had been erected in the 1970s. A number of the physical elements of the buildings structure proved ecologically dangerous. At one point, it had been discovered that toxins leaked into the groundwater supply, air quality was dangerous for inhabitants, and the building was constantly in flood danger in an already rainy Oregon climate. This eventually led to the church's decision to have it destroyed and rebuilt. This ultimately promised to make church life safer and more sustainable, for our children, our city, and the land.

The morning they tore it down was a clear, warm spring Oregon morning. Standing with my pastor, we watched as they demolished the building board-by-board, block-by-block. I noticed the material of the children's building was of such low quality that it stripped away like papier-mâché under the weight of the bulldozer's massive strength. Surprised, I wondered why it had been built so poorly, why it had been leaking toxins into the ground and wasting electricity, leading to our current need to tear it down and rebuild a new building in its place, even though it was built so recently. Thirty-five years seemed like, to me, a short time for a building's lifespan. Turning to my senior pastor, I asked why it had been so poorly built? He looked at the building and pondered my question for a moment. Then, turning to yell over the sound of the bulldozer, he loudly replied, "When they built this building, they thought in the next ten years Jesus would come back."

That day I learned a powerful lesson in my theological journey. In a very real and legitimate sense it became clear to me that our theological convictions, for better or worse, will inevitably shape our ecological landscape. It had already become clear to me 
that my religious convictions as a Christian emerged out of contexts such as where I lived, whom I knew, and what I read. The chances of being a Christian would be drastically diminished had I been born in Turkey or Iran; for surely, my geography shaped my theology. But the opposite side of this was a novel thought, compelling me to prod further. At the time, little did I recognize while standing and watching that building fall that in one fell swoop I had both gained a valuable lesson about Pentecostal (and Christian) eschatology. But similarly, I had virtually been handed the future topic of my dissertation in the area of Pentecostal ecotheology. This and other experiences have caused me to understand the dynamic role our theologies and traditions have in their power to shape and alter the very landscapes upon which we walk, depend, and grow our food. In the end, theological convictions have ecological implications. For instance, evangelistic zeal will often lead us to build more sizeable church buildings for more people. Our theology of sin leads to a view of creation that can often devalue the human body if not entirely demean it. Our theology of ethics affects our relationship to what we will (and will not) put into our bodies by forcing us to examine the overall effect our choices have. Our fascination for revival (especially in PC communities) leads us to fly cross-country to see what the buzz is all about. This reality is very much the case in the Christian communities we might find ourselves in. Ultimately, in retrospect, many of the theological trajectories that had been handed me as a young Pentecostal (which I am still) were in many ways environmentally unsustainable and ecologically dangerous. At the same time, Pentecostalism was a tradition that handed me a passionate love for Christ, his Kingdom, and the Bible. Yet, at the end of the day, what Pentecostalism offered me in 
hope, empowerment, healing, worship, and evangelistic zeal, it lacked in social justice, holistic soteriology, and responsible eschatology.

I began to wonder if my own eschatology was leaving a dangerously large carbon footprint that my children would not understand nor look favorably on years down the road. This, again, prodded me to look for those Pentecostal voices "crying in the wilderness" (Matt. 3:3), who could lead the way for me in shaping an ecological ethic within a Pentecostal context. As I began to engage the topic, it became clearer and clearer that many of the public and popular Pentecostal spokespersons conversed in a way that seemed to lack a linguistic sensitivity favorable to earth care. Yet it also seemed clear that from my earlier introduction to Pentecostal snake-handlers, there was in some form of Pentecostalism a latent theology of living alongside and in touch (literally) with nonhuman creation. This was a paradox. It eluded me as to why some Pentecostals would handle snakes, but cared little about the rest of creation. Ultimately, there were few popular spokespersons to look to. One such spokesperson was James Watt. Watt, a Pentecostal, was the Secretary of the Interior under president Ronald Reagan. Speaking to congress, Watt cautioned against worrying regarding the long-term policy of the government regarding natural resources, because, "I do not know how many future generations we can count on before the Lord returns. ${ }^{, 27}$ Then, in regards to why he ordered nearly 800 million acres of federal land to be opened for human exploitation, Watt remarked, "My responsibility is to follow the Scriptures which calls us to occupy

${ }^{27}$ W. Martin, "Waiting of the End." Atlantic Monthly 249 (June, 1992), 3-7. 
the land until Jesus returns. ${ }^{, 28}$ While not doubting Watt's personal piety or faith, I suspect many non-Christians cringed, as I did, as a fellow Pentecostal.

After time, to my elation, I found that there were voices in the wildernessalthough quiet voices. Some have called these "progressive Pentecostals," Pentecostal voices that spoke about social issues where the majority of Pentecostalism appeared to remain silent. ${ }^{29}$ To their credit, by and large, Pentecostals have taken strong stances against demons, disease, and poor exegesis - undoubtedly worthy causes for spiritual opposition. But as of yet, Pentecostals have struggled to face broader societal and social evils of our current day such as global hunger, political and economic corruptions, and the ecological crisis. Murray Dempster, one such Pentecostal progressive voice, has rightly called this Pentecostal struggle a "social quietism." ${ }^{30}$ Sadly, there are many evidences of such quietism towards ecological issues. For instance, illustrating this "social quietism" ecologically, Australian theologian Shane Clifton has pointed out that a review of nine decades of the monthly Australian Assemblies of God Evangel profits not one single article on ecological or environmental issues, except the "occasional reference to environmental destruction as proof of end-times prophecy."31 ${ }^{11}$ This, and other evidence,

\footnotetext{
${ }^{28}$ Quoted in Richard Hiers, "Ecology, Biblical Theology, and Methodology: Biblical Perspectives on the Environment," ZY 19.1 (1984), 43-59 (46).

29 "Progressive Pentecostals" is found throughout Donald Miller and Tetsunao Yamamori, Global Pentecostalism: The New Face of Christian Social Engagement (Berkeley: University of California Press, 2007). For a helpful overview of the relationship of North American Pentecostalism to social justice, see Michael Wilkenson and Steven Studebaker, eds., A Liberating Spirit: Pentecostals and Social Action in North America (Eugene: Pickwick, 2010).

${ }^{30}$ Murray Dempster, "Christian Social Concern in Pentecostal Perspective: Reformulating Pentecostal Eschatology," JPT 2 (1993), 51-64 (52).

${ }^{31}$ Thanks to Clifton for this on his website. See the complete collection of the Australian Evangel available at Pentecostal Heritage Centre, Southern Cross College. A selection of this collection has been digitized to date, available at http://aps.webjournals.org/. Original sourcing located at Clifton's website, see http://scc.typepad.com/scc_faculty_pentecostal_d/2006/05/pentecostals_an.html\#_edn2, (accessed June 21, 2010).
} 
seemed to highlight a Pentecostalism that is nothing more than, in one scholar's words, "un-ecological.",32

Yet what seems even stranger is that while Pentecostals have remained relatively "quiet" on the ecological issue, so have other Christian traditions in seeking out or including Pentecostal voices in their ecotheological dialogues. For instance, a recently published volume, Christianity and Ecology, devotes zero (of 720) pages to Pentecostal ecotheology. ${ }^{33}$ Furthermore, from what this author can find, not one single Pentecostal ecotheology contribution has been included in a non-Pentecostal work on ecotheological issues to date. Why is this the case? Some may suggest it is an ecumenical problem. Mel Robeck has aptly illustrated the problems with a Pentecostal uncritical alignment with the NAE and its move away from the WCC, ultimately severing potentially fruitful ecumenical relationships outside of Protestantism. ${ }^{34}$ This could perhaps explain why Pentecostals have been virtually absent from the ecological conversation on an ecumenical level. Other options remain. Could it be that Pentecostals feel they have nothing to offer what Cheryl Bridges John calls, "a Pentecostal low self-esteem"? ${ }^{35}$ Could it be that ecological care has been viewed by Pentecostals as against "the spontaneous

\footnotetext{
${ }^{32}$ In another fascinating piece, a "Pentecostal environmentalist" is caricatured as epitomizing the complexity of ecotheology in a late modern world. Laurel Kearns, "The Context of Eco-Theology," in The Blackwell Companion to Modern Theology, ed. Gareth Jones (New York: Blackwell, 2004), 464-484 (465).

${ }^{33}$ There is nothing regarding classic Pentecostal theology. Nonetheless, there is one brief (yet intriguing) article written from the perspective of the Charismatic African Earth-Keeping Churches (AICs), with a response by M.L. Daneel. Dieter Hessel and Rosemary Ruether, eds., Christianity and Ecology: Seeking the Well-Being of Earth and Humans (Cambridge: Harvard University Press, 2000).

${ }^{34}$ Cecil Robeck, "Taking Stock of Pentecostalism: The Personal Reflections of a Retiring Editor," PNEUMA 15.1 (1993), 35-61.

${ }^{35}$ On this "self-doubt" of Pentecostals, see Cheryl Bridges Johns, "The Adolescence of Pentecostalism: In Search of a Legitimate Sectarian Identity," PNEUMA 17.1 (1995), 3-17.
} 
and novel work of the Spirit," as Simon Chan has suggested regarding a Pentecostal fear of liturgical and creedal richness $?^{36}$

This “social quietism” Dempster spoke of ultimately led Jürgen Moltmann to ask, "Where are the charismata of the 'charismatics' in the everyday life of the world, in politics, in the peace movement, and in concern for ecology?"37 In seeking to answer Moltmann's question, the problem remains that emerging Pentecostal ecotheological voices remain much like their glossolalia; full of meaning, hard to distinguish, and in desperate need of a willing interpreter. For these ecological tongues do exist. But reasons abound as to why they often go unheard. Many of these reasons can be laid at the feet of the Pentecostals. Sadly, ecotheology remains for many in the movement an enemy of the "novel” work of the Spirit, being often viewed as a needless practical endeavor that ultimately takes away from the Spirit's real mission in the world today—soul-saving. ${ }^{38}$ Perhaps politics play a role in this as well. Some have blamed ecotheological talk as a "liberal front" biased against conservative capitalism, which is often the cultural homeland of American Pentecostalism. ${ }^{39}$ And finally, in eschatological fervor, others have eschewed ecotheology on the grounds that the earth will be consumed in a cataclysmic apocalypse at Christ's return. For these (and other) particularities,

\footnotetext{
${ }^{36}$ Simon Chan, Pentecostal Theology and the Christian Spiritual Tradition, JPTSup, vol. 21 (Sheffield: Sheffield Academic Press, 2000), 22-23.

${ }^{37}$ Jürgen Moltmann, Spirit of Life: A Universal Affirmation, trans., Margaret Kohl (Minneapolis: Fortress, 1997), 62, (italics mine).

${ }^{38}$ There remain a number of downsides to using the term "Spirit," three of which Donald Gelpi best describes in his work relating to dualism, essentialism, and transcendental Thomism. Donald Gelpi, The Divine Mother: A Trinitarian Theology of the Holy Spirit (Lanham: University Press of America, 1984), 11-13.

${ }^{39}$ Shane Clifton, "Preaching the 'Full Gospel' in the Context of the Global Environment Crises," in The Spirit Renews the Face of the Earth, ed. Amos Yong (Eugene: Pickwick, 2009), 117-134 (127). For a larger discussion critiquing the so-called two-party system of "liberalism" and "conservativism," see the insightful Douglas Jacobsen and William Trollinger, Re-Forming the Center: American Protestantism, 1900 to the Present (Grand Rapids: Eerdmans, 1998).
} 
Pentecostal experience and salvation remains virtually an individualistic affair in the West. And the Spirit's role in the ecological crisis is largely viewed as a distraction from the more important activity of soul winning.

We can now begin to see the increasing importance of ecotheology for Pentecostals in the twenty-first century. This thesis will argue that ecotheology in Pentecostalism is a renewal in the Spirit-filled experience. Furthermore, it is a critical questioning of any kind of anthropocentric individualistic soteriology, human-centered healing, and irresponsible eschatology that ignores the rest of God's created order. It will continue to suggest that a pneumatological experience of creation in God's world is a novel work of the Spirit, a renewed experience, and a return to the often forgotten creed in the biblical tradition, which stems back to Genesis 1 of caring for and living within God's earthly garden. For Pentecost's creed is experience-a renewed experience of all of creation made alive once again where "all flesh" is endowed with God's Spirit (Acts $2: 17)$. It is in this renewed experience that Pentecostals can again, in the words of Blumhardt, "convert back to this world," finding themselves making room for a soteriological vision for all of the created realm. ${ }^{40}$

Balance will be vital in this conversation. It is important that Christian institutions and communities be wary to buy entirely into any novel social agenda. And we must similarly proceed with humility, being aware that many of the Pentecostal critiques of an ecotheological development remain valid in their own way and should be valued on their own basis. Many social agendas — such as hunger eradication, political integrity, and

\footnotetext{
${ }^{40}$ Quotation found in J. Blumhardt, Ansprachen, Predigten, Andacten, Und Schriften, ed. J. Harder, vol. 1 (Neukirchen-Vluyn: Neukirchener Verlag, 1978), 12.
} 
ecological care—are indisputably works of God's Spirit. Yet, as with any social movement, the ecological crisis can be hijacked by political forces and powers for political means, thus defeating the original intention. ${ }^{41}$ Pentecostals will remind us that "recycling" will not populate heaven and that Jesus is still the soon and coming King no matter how important ecological care might be. But Pentecostal ecotheology will respond by arguing that preaching and practicing Christ's liberative freedom is paramount to Christian witness. Nevertheless, certainly these critiques must embrace a more sizeable vision of salvation beyond going to heaven. The best way forward, then, is for Pentecostals to recognize their participatory responsibility to two kingdoms: the Kingdom of heaven and the kingdom of earth. As theological history has taught us, ignoring either the Kingdom of heaven or earth minimizes the Spirit-filled responsibility. Ecological care, therefore, in this setting, is a Spirit-filled experience leading us to participate as commissioned people in the forces that created the universe in Genesis 1 and reconstituted at Pentecost in Acts 2. Caring for the very entity God entrusts to us is to love God himself as the parable of the vineyard reminds us (Matt. 20:1-16). Perhaps impatience for the soon coming Kingdom has led us astray from caring for the kingdom of this world. For, as Jesus's parable teaches us, impatience for the soon-coming king has never been a valid excuse for inadequate practice.

\footnotetext{
${ }^{41}$ While many remain, as an example of a critique of ecological politics as an extension of political hegemony, see Robert Royal, The Virgin and the Dynamo: Use and Abuse of Religion in Environmental Debates (Grand Rapids: Eerdmans, 1999). For a political examination of the landscape of various ecological issues, see Anthony Giddens, The Politics of Climate Change (Malden: Polity, 2009).
} 


\subsection{Methodology, Definitions, and Terminology}

Some level of methodological groundwork is necessary at the onset. Broadly, this project is a work in constructive theology whereby we will bring into dialogue the PC traditions, the ecumenical ecotheological community, and the biblical text to construct a theology of ecological care for Pentecostal communities. The eventual outcome is intended to be a foundation for further interaction inside and outside Pentecostal communities.

Yet how does one define Pentecostalism or the Charismatic movements? The seminal The New International Dictionary of Pentecostal and Charismatic Movements (NIDPCM) defines both as "the two great renewal movements of the Spirit" in the twentieth century. ${ }^{42}$ In what follows, the terms "Pentecostal" and "Pentecostalism(s)" will refer to classic denominational Pentecostalism stemming predominately from two central North American revivals in Topeka, Kansas (1900-02), under Charles F. Parham, and Los Angeles, California (1906-09), under William J. Seymour, which is popularly known as the Azusa Street Revival. The representative denominations that find their story in these two revivals will thus be defined as "Pentecostal." "Charismatic" (uppercase c), therefore, will refer to movements that have been influenced or sprouted from these classic Pentecostal movements, predominately in the 1960s and 1970s, within the mainline traditions, sharing a similar pneumatological persuasion. This will include "neo-

\footnotetext{
${ }^{42}$ Stanley M. Burgess and Eduard M. van der Maas, eds., The New International Dictionary of Pentecostal and Charismatic Movements (Grand Rapids: Zondervan, 2002), introduction.
} 
Charismatics" and "Third Wavers." ${ }^{43}$ The term "charismatic" (lowercase c) will be in reference to a state or quality, often in the spiritual sense, thus serving as an adjective of a number of characteristics common of both Pentecostalism and the Charismatic movements, mostly evidenced in their practical theology of the Holy Spirit. Finally, the shortened "PC," referring to both Pentecostal and Charismatic movements and their respective attributes, will be used throughout.

Since the Holy Spirit will be a central figure of this project, a brief note regarding gender and language is pertinent. As a cursory reading of the scriptural narrative illustrates, we find repeatedly the Spirit of God uncannily existing above and beyond in transcendent fashion over our various linguistic limitations. For instance, the biblical account exhibits both images of God as male (Rom. 8:15-Abba Father) and female (Isa. 66:13 - As a mother comforting her child). Pneumatologically, even amongst the development of theological language from the OT to the NT, we observe a move from God's Spirit being spoken of in the Hebrew feminine sense (rûach) to a more neutral Greek usage (pneuma). ${ }^{44}$ Thus, if language has value in theological formation, God (and God's Spirit) have proven inherently troublesome for language and our understanding of gender boundaries. There is a sense, theologically, that the Word will always transcend our words. Therefore, I find no reason to create a stumbling block regarding the limits of our language. Thus, we will refer to the Spirit as just that, the "Spirit" (or "God's Spirit").

\footnotetext{
${ }^{43}$ I would agree there exist many Pentecostalism(s). The North American Pentecostal movements utilized a number of nomenclatures, such as "Full Gospel," "Latter Rain," and "Apostolic Faith." For an examination of these nomenclatures, see William Faupel, The Everlasting Gospel: The Significance of Eschatology in the Development of Pentecostal Thought, JPTSup, vol. 10 (Sheffield: Sheffield Academic Press, 1996).

${ }^{44}$ It was the later Latin fathers who spoke of the Spirit in more male terminology-Spiritus. It is striking to note that in the language of the Western tradition, which borrowed heavily from both the OT and the NT, we observe in almost entirety a sex change of the Spirit in theological language from female to neuter to male in the span of nearly one thousand years.
} 
At times, when referring to the Spirit as a person, "him" or "her" may be used as best fitting the context. Denis Edwards, reflecting on these linguistic challenges, insists on the ascetical and mystical nature of the Spirit; as the one who "blows where it will." 45 This, Edwards is convinced, points to the reality that the Spirit is who the Spirit is where the Spirit wants to be. No less is this true on a linguistic level, as the Spirit vivaciously exists above and beyond our systems of language. As an extension of pneumatologyecopneumatology (ecological pneumatology) — exists as a corollary discipline synthesizing a theology of the Holy Spirit to that of a theology of ecology. Finally, it is clear there are significant problems with referring to "nature" or "environment" as though humans are beyond such. In this project, "creation" will be utilized as everything that is not God (including spiritual forces; i.e. angels). This goes beyond Steven BoumaPrediger who speaks of the earth. ${ }^{46}$ This is done on the basis that a broader universal/cosmic story, going beyond earth and including the entirety of the cosmological order, is evidenced in portions of the biblical witness.

Why has pneumatology been chosen here as the most promising area to attempt a constructive Pentecostal ecotheology? Why not eschatology, Christology, or ecclesiology? To begin, in general, pneumatology remains a bourgeoning field of study in Christian theology that is undergoing increased attention in the broader religious and cultural arena. Veli-Matti Kärkkäinen has called this a pneumatological "renaissance" in

\footnotetext{
45 Denis Edwards, Breath of Life: A Theology of the Creator Spirit (Maryknoll: Orbis, 2004), 3.

${ }^{46}$ Steven Bouma-Prediger, For the Beauty of the Earth: A Christian Vision for Creation Care (Grand Rapids: Baker Academic, 2001), 16-17. On the danger of using "nature" or "environment," with a very helpful yet critical discussion on the various issues these terms raise, see James Nash, "Towards the Ecological Reformation of Christianity," 7-10.
} 
theology as the study of God's Spirit that has reached somewhat of an all-time zenith. ${ }^{47}$ All this while the pneumatological scene in Christian theology has appeared somewhat bleaker in times past. The Eastern father Gregory of Nazianzus (329-390) sarcastically called the Spirit the pneuma agraptos, the Spirit about whom no one writes. ${ }^{48}$ Nicholas Berdyaev, another challenger to the lack of pneumatological theology in recent decades, comments that the Spirit is "the last unexplored theological frontier." $"$ Emil Bruner called the Spirit the "stepchild" of theology due to its ethereal nature, rarely fitting into logical/rational theology and continuously getting in the way of everything else. ${ }^{50}$ Likewise, it was George Sirks who famously called the Spirit "the Cinderella of Theology"- while the Father and Son are at the ball the Spirit cleans the floor. ${ }^{51}$ Finally, Sallie McFague recalls a conversation where she overheard someone confess, "I pray to the Spirit because I know the Father and the Son are too busy." 52 We could continue.

Yet the pneumatological scene appears to be evolving. Kärkkäinen has suggested two main reasons for a resurgence in pneumatology in contemporary Christian theology: first, the entrance of Eastern Orthodoxy into the WCC, and secondly, the growth of Pentecostal movements. ${ }^{53}$ With this, pneumatology will serve as a natural connector between Pentecostals and other Christian communities wrestling with issues of the Spirit.

\footnotetext{
${ }^{47}$ Throughout in Veli-Matti Kärkkäinen, Pneumatology: The Holy Spirit in Ecumenical, International and Contextual Perspective (Grand Rapids: Baker Academic, 2002).

${ }^{48}$ Donald Gelpi, "The Theological Challenge of Charismatic Spirituality," PNEUMA 20.2 (1992), 185-197 (185).

${ }^{49}$ Nicolas Berdyaev, Spirit and Reality, trans. Georges Reavey (London: Bles, 1946), 22.

${ }^{50}$ Emil Bruner, Das Missverstandnis Der Kirche (Zurich: Theologischer Verlag Zurich, 1988), 53-54.

${ }^{51}$ George Sirks, "The Cinderella of Theology: The Doctrine of the Holy Spirit," HTR 50.2 (1957), 77-90.

${ }^{52}$ Sallie McFague, A New Climate for Theology: God, the World, and Global Warming (Minneapolis: Fortress, 2008), 170.

${ }^{53}$ Veli-Matti Kärkkäinen, Pneumatology, Introduction.
} 
Furthermore, pneumatology is a Pentecostal favorite—a relish if you will. ${ }^{54}$ While Terry Cross has suggested Pentecostals need to bring more than just relish to the ecumenical table, we must remember, that at the end of the day, someone still needs to bring the relish. Pentecostal pneumatology may find a new setting to shine at a time when pneumatology has come to the forefront again in Christian theology. It allows Pentecostals to address a foreign subject—ecotheology—on the very familiar field of pneumatology.

With this pneumatological renaissance in context, a word must be spoken regarding the outlook of the author regarding his own personal experience of the Spirit. Undeniably, Pentecostalism has provided for millions of individuals a rich tradition of the Spirit that has awakened their comprehension of God, scripture, community, and the world. The author is included in this. Oddly enough, it is to the Pentecostal Spirit that I owe my love for creation. For I owe gratitude to my friends and teachers in the Pentecostal movement who taught me to love the Spirit in all creation, and to my teachers and friends outside the movement who taught me how to understand that Spirit theologically. ${ }^{55}$ It is for this reason I consider myself a "historic Charismatic." ${ }^{56} \mathrm{My}$ experience as a Pentecostal in a non-Pentecostal academic environment has given me a tremendously accommodating platform to understand the Spirit as being far outside of my own understanding and religious setting. I have come to appreciate the Spirit outside

\footnotetext{
${ }^{54}$ Terry Cross has suggested that in the context of ecumenical dialogue, Pentecostals must not reserve themselves just to bring pneumatology to the theological conversation. In the metaphor of a meal, Pentecostals are urged to bring more than simply a side of relish. Terry Cross, "The Rich Feast of Theology: Can Pentecostals Bring the Main Course or Only the Relish?" JPT 16 (2000), 27-47.

${ }^{55} \mathrm{I}$ am of course borrowing the phrasing of Hollenweger in the dedication to his Walter Hollenweger, The Pentecostals (Minneapolis: Augsburg, 1977).

${ }^{56}$ While I have encountered it elsewhere, my initial encounter with the phrase "historic Charismatic" was in Raymond Bakke, A Theology as Big as the City (Downer's Grove: IVP, 1997).
} 
the walls of my own Pentecostal world and experience. It seems obvious to me that other very important Pentecostal-like movements must be recognized as valid expressions of the Spirit's life. ${ }^{57}$ We cannot ignore the many flames of the Spirit manifest throughout the history of the Church. In the last two hundred years, Pentecostal-like revivals have colored the scene previous to North American Pentecostalism: the Welsh revival (190405), South Indian revival (1860), North East Indian revival (1905), Pune, India revival (1905-06), and a number of Korean revivals (1907-08). All of these seem to point to a Spirit at work both inside and outside classic American Pentecostalism. Ultimately, ecumenically and theologically, we must engage a Spirit that was not born in Topeka or Los Angeles. It is for this reason Pentecostalism must be understood beyond the American continent. Otherwise, it becomes an American venture such as that of McDonald's or Nike. The Spirit is not an American. Nor is it not in America. The Spirit is the Spirit and must be understood outside the context of global hegemony of any nationalistic setting. ${ }^{58}$ It is for this reason we must heed the wise words of Kärkkäinen: "The Spirit of God is no general spirit hovering above the world, nor does any one Christian tradition or church have a monopoly on the Spirit." ${ }^{" 59}$ This work will allow me the space to engage non-Pentecostal sources that have deeply shaped both my theology and experience of the Christian tradition.

\footnotetext{
${ }^{57}$ On these movements, see David Allen, The Unfailing Stream: Charismatic Movement through the Ages (London: Sovereign World Ltd., 2000); Allan Anderson, An Introduction to Pentecostalism: Global Charismatic Christianity (Cambridge: Cambridge University Press, 2004); Stanley Burgess, The Holy Spirit, 3 vols. (Peabody: Hendrickson, 1989); Mark Cartledge, Encountering the Spirit: The Charismatic Tradition (London: Darton Longman \& Todd, 2006), esp. 33-50.

${ }^{58}$ This is advanced similar to the critique of Sarojini Nadar who offers a challenge to neo-Pentecostal homogeneity seen on the level of hermeneutics. Sarojini Nadar, "The Bible Says! Feminism, Hermeneutics and Neo-Pentecostal Challenges," JTSA 134 (2009), 131-146.

${ }^{59}$ Veli-Matti Kärkkäinen and Amos Yong, eds., Toward a Pneumatological Theology (Lanham: University of America Press, 2002), vii.
} 


\subsection{Outline of Project}

Finally, before continuing, let us sketch an outline of this project, overviewing the flow of content and argument. Following this introductory chapter (chapter 1), chapter 2 will seek to overview how the larger non-Pentecostal Christian community has encountered and theologically engaged the ecological crisis through the RC, Orthodox, Protestant, and Ecofeminist traditions. This will serve as an overview chapter whereupon we will more adequately be situated to explore Pentecostal ecotheology in the context of the ecumenical Christian community. Chapter 3, digging deeper than the ecumenical ecotheology in the previous chapter, will mine the central PC voices as they have been made manifest in the last thirty-five years regarding the earth and creation with particular focus on how it has ecologically shaped the broader Pentecostal world. Chapter 4, as a set of dialogue partners in the field of ecopneumatology, will examine and critique three central dialogue partners from three of the traditions examined in chapter 2. Here, we will explore Denis Edwards's “Biocentric Spirit," Sallie McFague's "Hopeful Spirit,” and Mark Wallace's "Wounded Spirit." Chapter 5, digging even deeper into the theological paradigm of Pentecostalism, identifies four pneumatological themes which will be utilized to form the framework of a Pentecostal ecopneumatology: Spirit baptism, the Spirit of charismatic community, the holistic Spirit, and the Spirit of eschatological mission. Chapter 6 , our constructive chapter, utilizes these four pneumatological themes and will develop a distinctive Pentecostal ecopneumatological voice in dialogue with ecumenical ecotheology from chapter 2, Pentecostal ecotheology of chapter 3, the ecopneumatological partners from chapter 4, and Pentecostal pneumatology and theology 
at large. A conclusive and reflective section, chapter 7, will offer a succinct overview of the project, provide responses to potential challenges to the thesis, give suggestions for future possible areas of research for Pentecostal ecotheology, and offer the project's practical and ecclesiological implications. With this, we will have achieved a novel development within Pentecostal pneumatology in the twenty-first century regarding the ecological crisis. Let us move forward. 


\section{Chapter 2}

\section{THE GREEN SCENE-ECOTHEOLOGY IN CONTEXT}

"Any error about creation also leads to an error about God." ${ }^{60}$ - St. Thomas Aquinas

Any sojourner would wisely bring along a map to better identify their surroundings in case they should get lost. This chapter exists for that purpose. On our journey towards a green Pentecostal ecopneumatology, we will be served by establishing a more extensive conceptual map of contemporary Christian ecotheology by examining the landscapes of RC, Protestant, Orthodox, and Ecofeminist theologies of creation. Here, we will effectively establish a theological and historical context for PC ecotheology in the late modern period. Following this experiment in ecotheological cartography, we will begin to be able to see afresh from a distinctively Pentecostal perspective. ${ }^{61}$ To that end, the purpose for examining such traditions will create a framework to represent the Pentecostal contribution to a Christian ecotheology in the twenty-first century. A few introductory comments are necessary before proceeding.

\footnotetext{
${ }^{60}$ Thomas Aquinas, Summa Contra Gentiles, II.3. Quoted in Steven Bouma-Predigar, For the Beauty of the Earth, 189. Some, such as Andrew Linzey, have critiqued Aquinas's creation theology on the basis that he made detrimental comments regarding nonrational creatures. Andrew Linzey, Animal Gospel: Christian Faith as Though Animals Mattered (London: Hodder \& Staughton, 1998), 22.

61 I borrow language regarding "theological cartography" from Jonathan Smith, Map Is Not Territory: Studies in the History of Religion (Chicago: University of Chicago Press, 1978).
} 


\subsection{Introduction}

The models of Christian ecotheology which we will encounter here are equally matched by novel ecological models. In broad strokes, recent ecological paradigmatic shifts have been paralleled by a number of freshly constructed theological ventures-ecotheology, Gaia theology, renewed ecoecumenism, among others - all of which reengage and reemphasize the essential interconnected nature of both God and the universe. In an academic climate largely formed by post-Einsteinian physics (later developing into string theory), a culminating ecological worldview that reconsiders the interconnectedness of the universe's natural order seems logical..$^{62}$ For instance, this interconnectedness is a vital theme discussed at length in James Lovelock's Gaia theory, which has enjoyed a number of theological dialogue partners, critics, and admirers. ${ }^{63}$ Lovelock's Gaia theory is a critical engagement of antiquated biological models founded on a bifurcated and static world and based on a closed-system paradigm. Within the Gaia model, the earth is conceptualized as a single living entity in sharp contrast to a static model of billions upon billions of separable parts, offering a critique of atomistic Western cosmology. Attempts are made in this to return to an overall sense of a holistic reality in contrast to an atomistic worldview. In this newer model, all living and nonliving entities are understood as interconnected through one living ecosystem depending on and supporting one another

\footnotetext{
62 Physics has similarly offered ecotheology a fruitful conversation partner. As an example, see Daniel Liderbach's synthesis of Jesus's Kingdom discourse to the most contemporary findings in physics. Daniel Liderbach, The Numinous Universe (New York: Paulist, 1989).

${ }^{63}$ For a helpful overview of Gaia theory, see James Lovelock, Gaia: A New Look at Life on Earth (Oxford: Oxford University Press, 1982); James Lovelock, The Ages of Gaia: A Biography of Our Living Earth (Oxford: Oxford University Press, 2000); James Lovelock, Homage to Gaia: The Life of an Independent Scientist (London: Oxford University Press, 2001).
} 
as one single living entity. Various contributors to Christian ecotheology have exuded a conversational openness on many fronts in relating to such models as Gaia theory. One such theological attempt to synthesize a Gaia worldview with a theological model is exemplified by Rosemary Ruether's Gaia and God. ${ }^{64}$

As we are going to see, every principal religious tradition is seeking to situate themselves theologically, philosophically, and practically in this ecological age. Roger Gottlieb's helpful and wide ranging text, This Sacred Earth, establishes and illustrates the diversity of such responses with contributions from each of the world's major religious traditions. ${ }^{65}$ For instance, the Buddhist ecological ethic has emerged from a philosophical framework of "detachment" and "nature respect." ${ }^{66}$ Similarly, Near Eastern religions have made seminal contributions to an emerging global ecotheology through traditions such as Jainism, Hinduism, and Judaism with its understanding of Tikkun Ha Olam or "World Repair." ${ }^{67}$ Islam has itself developed an ecological conscience that will continue to play an expanding role in the global discussion. ${ }^{68}$

\footnotetext{
${ }^{64}$ See Anne Primavesi, Gaia's Gift: Earth, Ourselves, and God after Copernicus (New York: Routledge, 2003); Rosemary Ruether, Gaia and God: An Ecofeminist Theology of Earth Healing (London: SCM, 1993).

${ }^{65}$ Roger Gottlieb, A Greener Faith: Religious Environmentalism and Our Planet's Future (Oxford: Oxford University Press, 2006). For two other introductory texts that expand on the larger relationship of religion to ecology, see the illustrative Mary Tucker and John Grim, Religions of the World and Ecology, 9 vols. (Cambridge: Harvard University Center for the Study of World Religions, 1997-2003).

${ }^{66}$ Jay McDaniel has synthesized a Zen Buddhist philosophy with ecotheology. Jay McDaniel, Earth, Sky, Gods \& Mortals: Developing an Ecological Spirituality (Mystic: Twenty-Third Publications, 1990).

${ }^{67}$ Tikkun Ha Olam, a Jewish ethical model, emphasizes the morality of eating and exercise as spiritual devotion. I first encountered this in Mary Randour, Animal Grace: Entering a Spiritual Relationship with Our Fellow Creatures (Novato: New World Library, 2000), 61. For other introductions to Jewish encounters with ecological issues see Ellen Bernstein, Ecology \& the Jewish Spirit: Where Nature and the Sacred Meet (Woodstock: Jewish Lights Publishers, 2000); Roger Gottlieb, A Spirituality of Resistance (New York: Crossroad, 1999). For a more philosophical approach to Jewish cosmology, see Abraham Heschel, God in Search of Man: A Philosophy of Judaism (New York: Noonday, 1993). Finally, as an approach to a praxis-oriented Jewish ethic, see the Coalition on the Environment and Jewish Life, To Till
} 
The persistent challenge in identifying a particular tradition's contribution remains that the voices of ecotheology have become more radically diversified as the twenty-first century has moved forward. Even the notion of speaking of God or ecology has shifted dramatically, where the West is no longer its only dialogue partner as the number of these ecological expressions continue to expand in both volume and variety. This diversity can, at times, create a theological challenge where previous lines of clarity no longer remain as visible as in times past. This diversity is without doubt a product of a late modern globalized world. Philip Jenkins has quipped regarding this situation, "Soon, the phrase, 'A White Christian' may sound like a curious oxymoron, as mildly surprising as 'a Swedish Buddhist.' Such people can exist, but a slight eccentricity is implied."'69 Here, in this diversity, every tradition proffers a unique approach to ecological issues in harmony with their own history, theology, and goals. Interdisciplinary studies have equally created new avenues of diverse thought and study. To be sure, ecology has affected more than just the theological climate. Emerging disciplines, such as ecopsychology, consider how humans think, live, and exist cognitively in their own ecological setting. ${ }^{70}$ Philosophically, ecophenomenology has become a salient topic in academic dialogue — and as with any influx of thought, some of these disciplines have

and to Tend: A Guide to Jewish Environmental Study and Action (New York: Coalition on the Environment and Jewish Life, 1995).

${ }^{68}$ For the expanding ecological discussions within Islamic communities, begin with Richard Foltz, Frederick Denny, and Baharuddin Haji, Islam and Ecology: A Bestowed Trust (Cambridge: Center for the Study of World Religions Harvard Divinity School, 2003); Fazlun Khalid and Joanne O'Brien, Islam and Ecology (New York: Cassell, 1992).

${ }^{69}$ Philip Jenkins, The Next Christendom: The Coming of Global Christianity (Oxford: Oxford University Press, 2002), 3.

${ }^{70}$ For introductions to the relationship between human psychology and the earth/spatial realm (i.e. ecopsychology), see Daniel Botkin, No Man's Garden: Thoreau and a New Vision for Civilization and Nature (Washington DC: Island Press for Shearwater Books, 2001); Fritjof Capra, The Hidden Connections: A Science for Sustainable Living (New York: Anchor, 2002); Tim Flannery, The Eternal Frontier: An Ecological History of North America and Its Peoples (London: Penguin, 2007); Theodore Roszak et. al., Ecopsychology: Restoring the Earth, Healing the Mind (San Francisco: Sierra Club, 1995). 
become radicalized or extremist. For instance, the "deep ecology" movement inaugurated by Arne Naess has questioned the assumptions of a "shallow ecology" worldview. In this, "shallow ecology" is caricatured as a human view of life which understands the human personhood (qualitatively) as ontologically more important than the remainder of earth. ${ }^{71}$ Sadly, the "deep ecology" movement has been the foundation for some radicalized ecoloigical movements which can resorts to violence and extremist ecological action in attempting to forward their ideology.

It is in this cradle of theological diversity that a Pentecostal ecotheology has been born; and to many it is rather oxymoronic. Some have wondered what Pentecostals, with their "other-worldly" cosmology and "giddy in the Spirit" faith have to do with ecological "God-talk"? ?2 Are not Pentecostals more concerned with salvation of souls, leaving the salvation of soil to science? This unnecessary dualism remains unsatisfactory to many amidst our emerging context especially in ecotheology. This is more so the case with the increased awareness of the importance of theological imagination in regards to how it shapes human practice under this new comprehension of the interconnected nature of theology to practice. ${ }^{73}$ In reaction to this dualism, should not Pentecostals care about the salvation of souls and soils as much as anybody? Undoubtedly, a Pentecostal engagement of the empirical sciences (such as ecology) does seem a bit backward; some

\footnotetext{
${ }^{71}$ Arne Naess, "The Shallow and the Deep, Long-Range Ecology Movement: A Summary," INQ 16 (1973), 95-101.

${ }^{72}$ I borrow the term "other-worldly" from Augustinus Dermawan, used often of Pentecostal movements in his, "The Spirit in Creation and Environmental Stewardship: A Preliminary Pentecostal Response Toward Ecological Theology," AJPS 6.2 (2003), 199-217.

${ }^{73}$ This is largely the point of Colin Morris, whose work has illustrated the integrative nature of theology to globalization. Morris reminds us how Post-9/11 (USA) and post-7/7 (UK) understandings of the world have illustrated how deeply important religious thinking remains. Colin Morris, Things Unshaken: Reflections on Faith and Terror (Werrington: Epworth, 2006).
} 
would say rather unnatural. ${ }^{74}$ But it is here we begin to see an epistemological roadblock for Pentecostal, and most notably, Christian theology. One may wonder if this perceived "backwardness" comes from the lingering effects of modernism finding its culmination in the dualistic divorce of theology from science. This divorce, an offshoot of Enlightenment skepticism with its demythological underpinnings, makes the reintegration of theology and science seem almost impossible when put in such black and white terminology. Undeniably, for Pentecostals, this set of dualistic assumptions was prominent in the setting of early American Pentecostalism and continues to be perpetuated in many of its communities today. ${ }^{75}$ This dualism has come first and foremost to fruition in the science/theology dialogue, each having grown up almost entirely autonomous from each other in the twenty-first century.

As a result, the late modern offspring of eighteenth and nineteenth century Western Enlightenment philosophies seem to be paying the price for this unwarranted bifurcation. By and large, culturally, philosophically, and developmentally, the modern era has been marked without apology by disenfranchisement and separation; or what Colin Gunton has described as a disengagement that has engendered alienation. ${ }^{76}$ Along the same lines, Robert Neville has characterized the modern era as displaying seven

\footnotetext{
${ }^{74}$ Although this is the case, there are increasing numbers of PCs engaging the empirical sciences from a theological background. For instance, see Mark Cartledge, Charismatic Glossolalia: An EmpiricalTheological Study (Aldershot: Ashgate, 2001); Amos Yong, Theology and Down Syndrome: Reimagining Disability in Late Modernity (Waco: Baylor University Press, 2007).

${ }^{75}$ This God/nature dualism is one of the prevenient dangers of our current situation and is one of the ongoing themes in Bouma-Prediger, For the Beauty of the Earth.

${ }^{76}$ The central force of his Colin Gunton, The One, the Three, and the Many: God, Creation, and the Culture of Modernity (Cambridge: Cambridge University Press, 1993). The question remains as to what a truly late modern environmental ethic will contribute. One, Tu-Wei Ming, has commented that we are so "seasoned in the Enlightenment mentality," we have difficulty seeing clearly. Quoted in Tucker and Grim, Worldviews and Ecology: Religion, Philosophy, and the Environment, 21. Richard Hofstadter calls this separation in American culture a "cult of alienation." Richard Hofstadter, Anti-Intellectualism in American Life (New York: Knopf, 1974), 412.
} 
characteristics, first and foremost the utopic ideal of the individual to be entirely autonomous in him/herself. ${ }^{77}$ By extension, a North American cultural Sitz im Leben is a case-in-point of this, having been widely documented in sociological literature as the late modern person increasingly sees himself/herself as an individual first, and secondly, part of their community. ${ }^{78}$

Taking into consideration this trend regarding its theological implications, Walter Brueggemann's analysis of the impact of modernism is rather accommodating here. Brueggemann points to three core influences behind this individualistic idealism: philosophical "objectivism" and the discovery of the sun-centered universe, the political dimension of Enlightenment epistemology, and mostly the rise of Baconian science which suggests humans have an ability to know the universe in such a way as to be above it. $^{79}$ It was for this very perspective — of human transcendence in the Christian narrativethat White blamed Western Christianity. Ultimately, separation and individualism in the context of human community has led to a widespread separation from the created order. In agreement, many ecotheologians and ecophilosophers have long theorized that this very modernity driven by dualism lies behind and before us as arguably the main driving force of humanity's alienation from and destruction of creation. In the words of Denis

\footnotetext{
77 Discussed throughout Neville, Religion in Late Modernity. Neville's other characterizations are that the real world only consists of the "measurable," nature can be manipulated, power is ultimate, duality of mind and body, personal identity can be separate from personal history, and the overarching metaphor of the machine for social systems.

${ }^{78}$ As seen in the groundbreaking sociological texts, Robert Bellah, et. al., Habits of the Heart: Individualism and Commitment in American Life (Berkeley: University of California Press, 2008); Robert Putnam, Bowling Alone: The Collapse and Revival of American Community (London: Simon \& Schuster, 2001).

${ }^{79}$ Walter Brueggemann, Theology of the Old Testament: Testimony, Dispute, Advocacy (Minneapolis: Fortress, 1997), 8-9.
} 
Edwards echoing this, "dualism is bad theology." ${ }^{" 80}$ For post-Enlightenment existence has shown a humanity having grown nearly autonomous from creation and their community in nearly every way, perhaps leading to a latent policy in Christian theology which we may call the separation of church from creation.

The reasons behind the widespread separation of science and theology may be discovered within the context of this modern autonomy of which we are speaking. If this is true, then ecotheology is a sign that new ways of moving forward are possible as the ecological and theological begin to work hand in hand in a fresh setting. In scientific and theological discourse (especially regarding ecological issues) this dualism too often wins the day with both sides unwilling to continue fruitful dialogue for enriched practice in light of the ecological crisis. ${ }^{81}$ To further complicate issues, even some nontheists have pointed their academic guns at scientism as the reason behind the ecological disaster. ${ }^{82}$ Many scientists likewise blame the religious community. And so on and so forth. But this blame game is nothing new. As did Adam and Eve, each side seems to be blaming the other for the current situation.

This leads us to an important point: Christian ecotheology of which we will observe, on some level, will claim to offer practical and theological answers to

\footnotetext{
${ }^{80}$ Edwards, Jesus and the Cosmos, 23.

${ }^{81}$ There remain excellent examples of thoughtful practical theologians who critically engage scientism on a popular level. For instance, Kentucky farmer Wendell Berry has done important work to at least engage the issues that have arisen, in particular his engagement of E.O. Wilson. Wendell Berry, Life Is a Miracle: An Essay against Modern Superstition (Washington DC: Counterpoint, 2001).

${ }^{82}$ Scientism is here defined as the unquestioning allegiance to science. For two examples, see Carolyn Merchant, The Death of Nature: Women, Ecology and the Scientific Revolution (New York: HarperCollins, 1989); George Sessions, Deep Ecology for the Twenty-First Century (Boston: Shambhala, 1995).
} 
technological and ecological questions. ${ }^{83}$ This demonstrates an excitingly new potential relationship between science and theology. ${ }^{84}$ Yet the question at hand of course begs the larger philosophical question regarding this relationship between science and theology: can Christian theology, change, alter, or inform our scientific understanding of the world? Much of the ecotheology we are going to engage will answer this question with a resounding yes. This is by no means a novel question. We are reminded of Paul Tillich's position in considering the differences, if they exist, between science and theology. For the purposes of ecotheology, Tillich's response continues to echo a kernel of truth today. Religion and theology have one thing in common with science. Tillich called these searches of science and theology the quests for "ultimate concern." ${ }^{85}$ While this writer holds methodological reservations for Tillich's overall framework, we must nonetheless concur to some degree that both are seeking truth in their own way. On that basis alone both must renew a willingness to learn from the other.

Sadly, in the West, where this Spirit/matter dualism has primarily reigned, science and theology rarely, if ever, openly and humbly dialogue with one another. This is represented in a number of recent popular environmental writings. For instance, a recently published popular work highlighting the fifty greatest environmental thinkers in

\footnotetext{
${ }^{83}$ Ian Barbour, believed by many to be the progenitor of the science/religion dialogue, makes the case that there are five challenges to religious beliefs by the scientific community. He lists them as (1) belief in a personal God, (2) the human genome, (3) neuroscience's contribution to understanding of intelligence, (4) process philosophy, and (5) the role of God in nature. Ian G. Barbour, Nature, Human Nature, and God (Minneapolis: Fortress, 2002). Similarly, the number of texts on the possible symbiotic relationship between science and faith (even PC faith) have grown exponentially. For example, see the classic Morton Kelsey, Encounter with God: A Theology of Christian Experience (New York: Paulist, 1987).

${ }^{84}$ To borrow a quote of Albert Einstein, "Science without religion is lame and religion without science is blind." Quoted in Ernest Simmons, "Towards a Kenotic Pneumatology: Quantum Field Theory and the Theology of the Cross," CTNS 19.1 (1999), 11-16 (11).

${ }^{85}$ Paul Tillich and Robert Kimball, Theology of Culture (New York: Oxford University Press, 1959), 9.
} 
history listed Karl Marx to the exclusion of Sallie McFague, Bill McKibben, and Wendell Berry ${ }^{86}$ But Christian theology has been equally as guilty where many religious and theological texts concerning the environment have almost entirely muted the expressions of nontheistic environmental thinkers such as E.O. Wilson, Rachel Carson, and Lynn White, who very well may offer a number of excellent contributions to potential theological constructions.$^{87}$ Ecotheology, therefore, as a theological discipline, is the reintroduction of two potential areas of study (theology and science) in place of the disintegration of this modern Baconian autonomy we have been speaking of. Similarly, it is the attempt to read creation en optimam partem —in the best light possible—dialoging with scientific and theological paradigms.

The general willingness by both science and theology to learn from and engage one another in ongoing and sustainable ways is not shared by all ${ }^{88}$ While reservations remain by both in the science/theology dialogue to formalize ongoing discussions, theologians and scientists are making calls to mitigate this unnecessary chasm. For if science truly desires "ultimate truth," then their willingness for any new "paradigm," which is ultimately accommodating, must always be in want if older paradigms fail. ${ }^{89}$

\footnotetext{
${ }^{86}$ Joy Palmer, Fifty Key Thinkers on the Environment (London: Routledge, 2001).

${ }^{87}$ It should be noted that in the final paragraph of White's famous article in 1967, he concludes that St. Francis of Assisi should be remembered and revered as the "patron saint of ecology." White's argument, often received as an attack by many, does not appear to be a critique without hope; rather a spur for increased dialogue and theological imagination.

${ }^{88}$ One reason behind this could be "specialization," the separation and systematizing of disciplines of knowledge. This, as with the science/theology chasm, is one of the fruits of the modernist bifurcation in academic settings. Furthermore, I would argue one of the helpful benefits of late modern deconstructionism and the proliferation of information to the masses is the opening of new fields to previously unwelcome guests such as Pentecostal ecotheology. On "specialization" as it relates to science and theology, see Richard Feynman, The Pleasure of Finding Things Out: The Best Short Works of Richard P. Feynman (Cambridge: Perseus, 1999), 245-257.

${ }^{89}$ Borrowed here is Kuhn's language of "paradigms.” Thomas Kuhn, The Structure of Scientific Revolutions (Chicago: University of Chicago Press, 1996), 14. Any theological paradigm should account
} 
Christian theology must be as hungry as any for the truth. But it goes without saying that new paradigms, where science and theology learn from one another, can be as equally complex. In this process of discovering an ecotheology, Pentecostals must eschew oversimplification. The methodological issues regarding ecotheology are undeniably complex, leading to increasingly oversimplified responses in light of such complexity. For instance, John Reader, in his text Local Theology, surmises that Christians and churches have responded in three ways to the global ecological crisis. ${ }^{90}$ He argues initially that many have simply ignored it. Secondly, many have engaged it and simply offered pat theological answers, which in the end tends to be problematic. Or third, they have bought into green ideology hook, line, and sinker, simply using Christian theological language to gloss over their new green theology. Reader, and others, tend towards oversimplification regarding the issues either out of ignorance or lack of comprehension. While one may sympathize with Reader's critique on the Christian response to green issues, his account unfortunately does little justice to the significant work being done globally from a theological perspective or to the general complexity of these issues. Broadly, in the Christian tradition, much hard work has been invested in a practical theology of the earth. In contrast to Reader, what is needed is a willingness to go beyond a change in semantics, as Reader has argued many have done, to an actual change in thinking and practice.

Thus, in an effort to transcend oversimplification and underwrite a theology for the entire cosmos, we need a bigger map. As a mapmaker would perhaps warn us, old

not only for the religious and theological data, but account as well for as much scientific finding as best possible. This is a classic contribution of the science/theology dialogue. On this, see Sanborn Brown, "Can Physics Contribute to Theology?," ZY 40.2 (2005), 495-501.

90 John Reader, Local Theology: Church and Community in Dialogue (London: SPCK, 1994). 
roads can never lead to new places. Therefore, a new road is needed that is forged by truth where it has been found. Beginning by looking down new roads, beginning with current ecotheology, we will arrive somewhere new—a distinctively PC ecotheology. For if it is in the map of our own "constellation of facts, theories, and methods" ${ }^{\text {"1 }}$ we find something lacking, it is the honest search for the essence of true reality that we will look anywhere, beginning with historical ecotheology, for clues to "look in new places." If this is true in scientific inquiry, it must be even truer in pursuit of the Spirit's truth in Christian theology. No doubt many questions remain, but we must, if we are to continue in honesty and integrity, find willingness to open ourselves to historical ecotheology, mining it for truth wherever it may be found. In the same way Karl Polanyi argued in The Great Transformation that modernity has forced societal and relational structures to serve economic drive, we must submit that the ecological crisis has forced Pentecostal theology to serve the needs of the time. ${ }^{93}$ The initial place to discover a Pentecostal emerging ecotheology is in the pages of Christian ecotheology, as a form of historical analysis of the Spirit's voice through the historical church. To that end, this chapter will be a broadstroked attempt at an ecotheology typology from a PC perspective, as found in RC, Orthodox, Protestant, and Ecofeminist ecotheologies.

\footnotetext{
${ }^{91}$ Kuhn, The Structure of Scientific Revolutions, 1.

${ }^{92}$ Ibid., 111.

${ }^{93}$ Karl Polanyi, The Great Transformation (New York: Farrar \& Rinehart, 1944).
} 


\subsection{Roman Catholic Ecotheology}

Setting our theological cartography in motion, we now focus our attention on RC ecotheology. RC ecotheology is a cornerstone of the Western ecotheological landscape, sitting at the center of the crosshairs of post-White modern criticism which charges Western religion for earth's destruction. ${ }^{94}$ The marriage of the Western Weltanschauung and RC historical theology which we have mentioned, with both benefits and pitfalls, has been documented at length in recent years through a sea of literature. ${ }^{95}$ Concurrent with this, a significant portion of the ecological blame has been placed squarely on the RC tradition because of this perceived marriage to Western culture. But this is unfair when it becomes understood that many non-Western forms of RC theology and praxis exist on a global scale even while the majority remains largely impacted by Western paradigms. All the while, $\mathrm{RC}$ ecotheology has shown many creative theological advances regarding the interwoven relationship of God, creation, ecotheology, and late modern human existence. This diverse array of theological trajectories bring into question many of the modern criticisms voiced in recent years of Western Christianity's role in the destruction of the planet. And at times they are less criticisms of the Christian tradition than they are Western culture and philosophy in which it is often enveloped. Within this context, RC ecotheology has given language and form to a broader narrative of social justice; a

\footnotetext{
${ }^{94}$ For a brief yet helpful historical overview of the RC response to the issues raised by White until most recently, see Walter Grazer, "Strategy for Environmental Engagement: Building a Catholic Constituency," in Christianity and Ecology: Seeking the Well-Being of Earth and Humans, eds. Dieter Hessel and Rosemary Ruether (Cambridge: Harvard University, 2000), 578-587.

${ }^{95}$ For a seminal discussion on the imbeddedness of Western philosophy in theology and culture in general within any contextual theological construction with particular attention from a RC scholar, see Stephen Bevans, Models of Contextual Theology (Maryknoll: Orbis, 2002). For a larger vision of the connection between RC thought to Western frameworks, see Roger Olson, The Story of Christian Theology: 20 Centuries of Tradition and Reform (Downer's Grove: IVP, 1999). Western forms of religion are often painted as significantly less helpful for ecological purposes, as discussed throughout in Tucker and Grim, Worldviews and Ecology.
} 
theological tradition that must be heard and understood in its own right apart from Western philosophy. Therefore, we should strive to read RC ecotheology on its own, if possible, for its own value so that it can rightly be understood as a separate entity from the West.

Against this onslaught of criticism, RC ecotheology has developed beyond its apparent "managerial," destructive, and disrespectful attitudes towards the earth. ${ }^{96}$ Contemporary RC ecospirituality provokes rich theological discussion on a renewed vision of the "integrity of creation" and opens the door for praxis-centered Christianity. Just as RC is diverse sociologically and geographically, so is its ecotheology. The literature is expansive and diverse with expressions from a growing cadre of perspectives. ${ }^{97}$ Some have assumed a more liberation-centered format and some perpetuate a more reactionary tone against a Western milieu. ${ }^{98}$ Others, more sympathetic to the Christian tradition, reserve major doubts as to whether RC Christianity (Western or

\footnotetext{
96 "Managerial" is a pejorative term used by many critical of the Christian tradition. For example, see the reading of Patrick Curry, Ecological Ethics: An Introduction (Cambridge: Polity, 2006). Elizabeth Johnson has argued that since the Reformation, "neither Catholic nor Protestant theology continued to include the earth as a subject of interest." She suggests this was due to the soreness left on the RC tradition following the Galileo affair which proved rather embarrassing for RCs. Elizabeth Johnson, "Losing and Finding Faith in the Christian Tradition," in Christianity and Ecology, eds. Dieter Hessel and Rosemary Ruether (Cambridge: Harvard University Press, 2000), 3-21 (7-9).

${ }^{97}$ For instance, there are, among others, ecofeminist, lesbian/gay, African, and Asian RC ecotheologies. We must be careful to not caricature RC theology as inherently Western as its diversity makes itself clear from the onset. For a critical response of the notion that Christianity poses one singular view of ecology, see Susan Bratton, "The Original Desert Solitaire: Early Christian Monasticism and Wilderness," EE 10 (1988), 31-53.

${ }^{98}$ For some helpful primers on the overarching vision of liberation theology, see José Comblin and Phillip Berryman, Called for Freedom: The Changing Context of Liberation Theology (Maryknoll: Orbis, 1998); Gustavo Gutierrez, A Theology of Liberation: History, Politics, and Salvation (New York: Orbis, 1973); Brian Mahan and L. Dale Richesin, The Challenge of Liberation Theology: A First World Response (Maryknoll: Orbis, 1981). "Integrity of Creation" is the language of the sixth assembly of the WCC in Vancouver, BC (1983) as the intent of God to keep whole the earth's purity and sanctity.
} 
not) has the wherewithal to escape its ecologically detrimental patterns. ${ }^{99}$ Despite this diversity, one must credit the RC tradition with its openness to ecotheology despite its apparent "embeddedness" in Western culture. ${ }^{100}$ Historically, there remains a longstanding theology of ecological discourse in RC thought that leads the ecotheology discussion, especially on an ecumenical level.

As RC theology has been progressively open to and changed by the ecological conversation in the Christian and non-Christian settings, it has inevitably taken a much more significant role since the mid to late-twentieth century when environmental issues became more prominent in both academic and popular venues. ${ }^{101}$ Has this openness to the ecological discussion arisen from its historical theology? In many ways, RC ecotheology has pre-dated much of the Western ecological movement. RC ecotheological expressions have historically played a predominant role in developing an ecological conscience far before the ecological awakening of the twentieth century when science discovered a growing depletion of the ozone or the publication of Carson's Silent Spring. For instance, the historical voices of Francis of Assisi and St. Benedict, to the modern Teilhard de Chardin, to liberation expressions of Leonardo Boff, and ecofeminist theology of Sallie McFague, to the much more progressive Matthew Fox, Juan Luis Segundo, and Thomas Berry, RC ecotheology has taken a historical approach and developed a more prominent

\footnotetext{
${ }^{99}$ So John Passmore, Man's Responsibility for Nature: Ecological Problems and Western Traditions (London: Duckworth Press, 1972), 39-40, 184.

${ }^{100}$ I utilize here and elsewhere Ronald Allen's idea of "embedded theology." Allen defines this as a theology deeply engrained in a tradition. Ronald Allen, Thinking Theologically: The Preacher as Theologian (Minneapolis: Fortress, 2008).

${ }^{101}$ For an overview of RC relationship to science and the ecological community, see David Lindberg and Ronald Numbers, God and Nature: Historical Essays on the Encounter between Christianity and Science (Berkeley: University of California Press, 1986).
} 
and mainstream role, having begun to heavily affect lay theology abroad as we enter a new age of the ecological conscience. ${ }^{102}$

Many contemporary strides have been attempted in RC praxis and theology to develop an updated ecological ethic. For instance, on the world day of peace (January 1, 1990), Pope John Paul II offered his well-known "Peace with God the Creator, Peace with all of Creation" as public proclamation of God's peace for all creation. ${ }^{103}$ Following John Paul's death, Newsweek magazine called his successor, Pope Benedict XVI, "the Green Pope."104 This was in reference to Benedict and the Vatican City's efforts to be the first carbon-neutral country in the world. There are other green movements in the RC context. For example, the Green Sisters movement is worth noting. The Green Sisters, an organic lay-level movement of ecologically conscious nuns, are attempting to recreate the landscape of RC social work through ecological discipline, creation care, and ecotheological training. ${ }^{105} \mathrm{RC}$ ecotheology has, as well, shaped many others' work. For instance, the work of post-World War II economist E.F. Shumacher has played a key role

\footnotetext{
102 Thomas Berry has called this the "Ecozoic Age." Thomas Berry and Mary Tucker, Evening Thoughts: Reflecting on Earth as Sacred Community (San Francisco: Sierra Club Books, 2006), 23. Juan Segundo, a RC scholar, synthesizes liberation theology to the greater issues of cosmology and ecology. Juan Segundo, An Evolutionary Approach to Jesus of Nazareth (Maryknoll: Orbis, 1988).

${ }^{103}$ For extensive overviews of Pope John Paul II's ecotheology, see both Pope John Paul II, Sollicitudo Rei Scialis: On Social Concerns (Homebush: St. Paul Productions, 1988); Frederick Krueger and Pope John Paul II, The Ecological Crisis Is a Moral Crisis: A Summary of Pope John Paul II on Environmental Responsibility, Including His Spiritual Directions on Creation Care to the Faithful and All Society, 2nd ed. (Santa Rosa: Religious Campaign for Forest Conservation, 2003). Similarly, for a helpful critique and overview of the Papal teachings on the earth in the last century see Fred Kammer, Doing Faithjustice: An Introduction to Catholic Social Thought (New York: Paulist, 1991). A more critical engagement of changes in a post-Vatican II context in light of socioeconomic shifts is found at Uzochukwu Jude Njoku, "The Influence of Changes in Socio-Economic Thinking on the Development of Post-Vatican II Catholic Social Teaching," PT 8.2 (2007), 235-248. For "Peace with God the Creator, Peace with all Creation," see http://conservation.catholic.org/ecologicalcrisis.htm, (accessed August 18, 2008).

${ }^{104}$ Found at http://www.newsweek.com/id/132523, (accessed July 4, 2008). Again, Elizabeth Johnson has argued that one of the greater roadblocks to future ecological awareness is inhibited by the inherent hierarchical structure of the RC tradition. Johnson, "Losing and Finding Faith in the Christian Tradition," 12.

${ }^{105}$ Sarah Taylor, Green Sisters: A Spiritual Ecology (Cambridge: Harvard University Press, 2007).
} 
in developing public opinion of economic policy and praxis. ${ }^{106}$ Shumacher was deeply affected by RC theology and ecological writings. Quite clearly though — from a historical perspective - nothing is new. RC theology previous to John Paul II's “The Ecological Crises: A Common Responsibility,"107 Teilhard de Chardin, Thomas Aquinas in the high middle ages, and further back to St. Francis of Assisi, have played a pivotal role in keeping theological focus on ecological issues while on one hand creating a new social conscience and on the other attempting to be faithful to church creed and dogma. ${ }^{108}$ But what is the theological backing to RC ecotheology? Here, I would like to highlight three main trajectories prevalent in contemporary RC ecotheology: creation theology, dignitas terrea, and liberation theologies.

First, we pay close attention to a strain in RC ecotheology often called creation theology; a theological endeavor that seeks to situate God's created order as the central motif of the Christian theological imagination. Two representative theologians-Matthew Fox and Raimon Panikkar-will best offer us examples of this trajectory. We begin with Fox. Matthew Fox - a postdenominational and post-Dominican priest - has constructed a creation theology that climaxes in his groundbreaking text, Original Blessing (2000). ${ }^{109}$ Fox's main focal point throughout arises with the conviction that the human community

\footnotetext{
106 E.F. Schumacher, Small Is Beautiful (New York: Harper \& Row, 1973).

107 Cited in Gottlieb, This Sacred Earth, 202-209.

${ }^{108}$ LaChance makes the case that RC ecotheology has, by and large, been faithful to church creeds. Albert LaChance and John Carrol, Embracing Earth: Catholic Approaches to Ecology (Maryknoll: Orbis, 1994).

${ }^{109}$ Matthew Fox, Original Blessing: A Primer in Creation Spirituality (New York: Putnam, 2000). Although Fox no longer remains in the RC tradition, his writings and lectures are cited with regularity both in RC and ecumenical ecotheology abroad. Before leaving RC, Fox held significant weight theologically in the ecological dialogue, a weight he still holds in many ways. For a helpful overview of Fox's creation theology, see Matthew Fox, The Coming of the Cosmic Christ: The Healing of Mother Earth and the Birth of a Global Renaissance (San Francisco: Harper Collins, 1980); Matthew Fox and Rupert Sheldrake, Natural Grace: Dialogues on Creation, Darkness, and the Soul in Spirituality and Science (New York: Doubleday, 1996).
} 
lacks a "living cosmology" that links responsible theological method to the brevity of scientific data concerning the complexity and ancient nature of the earth. ${ }^{110}$ That is, the Christian gospel has been minimized to only half of the story — the human story. Through Fox, what creation theology attempts to do is retell the story of earth in light of mystical readings of theology and scientific narratives of creation. Simply put, the earth's destruction arises from a human ignorance of a God that is invested in creation, his love of said creation, and humanity's role therein. Fox does this in an overarching attempt to synthesize post-Darwinian cosmology with the medieval mystic theology drawn primarily from the wells of Meister Eckhart, St. John of the Cross, and Thomas Aquinas. ${ }^{111}$ As such, Fox's creation theology emphasizes the essential goodness of creation, while also stressing the human call to interconnectedness and interactivity with creation. Along with a cacophony of similar RC thinkers, Fox has given much impetus to anti-Western and anti-institutional forms of ecclesiology and theology in general. Comparatively to Fox, Diarmuid O'Murchu proposes a similar mystical vision that challenges current paradigms of earth theology. ${ }^{112}$

Alongside Fox is Raimon Panikkar, a prominent figure in interreligious dialogue and theology of religions. In Panikkar's text, The Cosmotheandric Experience (1993), he describes what he calls a "cosmotheandric" vision of God, earth, and human

\footnotetext{
${ }^{110}$ Fox, The Coming of the Cosmic Christ, 1.

${ }^{111}$ Broadly, creation theology, such as that found in Fox and Panikkar, relies heavily not just on the medieval mystics, but offers a return to the apophatic traditions (theologia negativa).

${ }^{112}$ For examples of O'Murchu's creation theology, see Diarmuid O'Murchu, Quantum Theology (New York: Crossroad, 1997); Diarmuid O’Murchu, Reclaiming Spirituality: A New Spiritual Framework for Today's World (New York: Crossroad, 1998); Diarmuid O’Murchu, Evolutionary Faith: Redisovering God in Our Great Story (Maryknoll: Orbis, 2002); Diarmuid O’Murchu, “Teilhard: A Mystical Survivor!," ECO 10.1 (2005), 99-108.
} 
spirituality. ${ }^{113}$ Here, he defines a holistic vision of creation and earth as "the totally integrated intuition of the seamless fabric of the entire reality." 114 It is in this "cosmotheandric" experience that humanity is "capable of the most profound encounter with the divine mystery"; a mystery whereupon we encounter both God and his created order in a new spiritual light. ${ }^{115}$ For our purposes here, Panikkar remains a crucial player in $\mathrm{RC}$ ecoconscience and has deeply influenced much of the contemporary creation theology movement, as evidenced by Fox's continued dialogical reliance on Panikkar's work in his own writing endeavors. Although Panikkar has been an impact on many in the $\mathrm{RC}$ community as a priest in Spain, he has been considered unpalpable to many on the theological and political right because of his reliance on Eastern religious paradigms. Nevertheless, Panikkar will remain to be an important ecological dialogue partner for years to come. Broadly, his ecotheology has been heavily influenced by Hindu, Vedic, and Eastern philosophical and religious thought which itself is developing intriguing engagements with ecology, illustrating for us how Eastern theological imagination reserves significant space for earth friendly theology. ${ }^{116}$ For in large part, Eastern earththought tends to migrate more to the pantheistic/mystical, often boding a more ready willingness for dialogue on theologies of the earth.

\footnotetext{
${ }^{113}$ Raimundo Panikkar and Scott Eastham, The Cosmotheandric Experience: Emerging Religious Consciousness (Maryknoll: Orbis, 1993).

${ }^{114}$ Ibid., 1.

${ }^{115}$ Raimundo Panikkar, The Experience of God: Icons of the Mystery (Minneapolis: Fortress, 2006), 127.

116 This is perhaps the greatest critique from a more theologically conservative perspective regarding Panikkar's overall line of thought. For related works on Hindu and Vedic engagements with ecology, see Christopher Chapple, Hinduism and Ecology: The Intersection of Earth, Sky, and Water (Cambridge: Harvard University Press, 2000); Ranchor Prime, Hinduism and Ecology: Seeds of Truth (New Delhi: Motilal Banarsidass Publishers, 1994).
} 
Creation theology through Panikkar, Fox, and others fleshes out a theological correction of sorts. It represents, by and large, both a correction against Augustinian theology and a positive reassessment of the medieval mystics for a contemporary setting. That is, against a theology emphasizing the depraved and fallen nature of creation, creation theology underscores creation's essential beauty and goodness. The creation was made good, they remind us, not bad (Gen. 1:4,10,12). What creation theology attempts to do is suggest that Western Augustinian theology spuriously forces upon the church and Christian community a way of imagining physical matter, flesh, creation, and human livelihood in overtly negative ways. This Augustinian theology, they claim, hinges upon the sin and fall of humanity. For creation theology, this claims to represent a line of thought that seeks to balance its Augustinian counterpart claiming it should not go unchecked, so as to create balance between the "depravity" and "sinfulness" of creation, emphasized by Augustine (post-sin) with its "goodness" (pre-sin).

Although the question remains, have Fox and Panikkar, and others in the creation theology school taken their reaction a bit far in throwing the aspects of the Western and Augustinian baby out with the modern bathwater? Perhaps so. For there is no doubt that a cursory overview of current creation theology in publication will show an element of anti-Western sentiment; while at times helpful and at times overstated. Nonetheless, this is not to suggest that reaction is not a perennial necessity and should be accomodated in the renewal of all theological discussions. It certainly is. But many amongst the RC tradition, most notably the theologically conservative, find difficulty engaging in creation theology because it assumes scientific presuppositionalism, welcomes Eastern religion, or simply has a New Age twang. Moving forward, the continuing challenge for the RC 
tradition will be a critical engagement both of Western pitfalls and constructive theological courage that has something to present and remains faithful to RC orthodoxy but does not need to remain married to Plato or Augustine.

Similarly, creation theology discerns itself as a reenvisioned eschatology where the Kingdom of God is reportrayed, not solely as the "far off," but also in the "here and now." That is, this bifid eschatological nature must remain intact for social justice to have the theological energy it requires to inaugurate the Kingdom of Christ. It would be suggested that a "far off" eschatology, which posits Christ's return primarily in apocalyptic and destructive terms, has undeniable ecological consequences. This eschatological turn submits that caring for creation is a necessary outflow of eschatology based in the present, a "realized eschatology," or what Catherine Keller has aptly called the "Greening of Eschatology." ${ }^{117}$ For a vast portion of RC ecological discourse appears to remain comfortably at home with a sense of "realized" eschatology, seeing the need for an eschatological vision concerned with the "kingdom come even as it is in heaven" at its helm (Matt. 6:10). Christ's reign is seen as the "here and now," not only ecclesiologically in Christ's church, but ecologically as well, in Christ's world. How is this played out in RC practice? This is certainly evidenced in RC social zeal shown in various corners of ecclesial life: liberationist theologies, RC ecofeminism, etc. Far more advanced is RC in social issues of liberation theology, feeding of the homeless, caring for victims of AIDS, and our current issue of ecological devastation. This eschatological reconfiguration is represented by Christine Hinze's work. Hinze has further suggested

\footnotetext{
117 Catherine Keller, "Talk About the Weather: The Greening of Eschatology," in Ecofeminism and the Sacred (New York: Continuum, 1993), 30-49.
} 
that ecojustice in a $\mathrm{RC}$ framework must account not just for the earth but the destitute in the human realm, arguing that, "the two, in fact, entail one another."118 Thus, spiritual and physical health are practical embodiments of the inaugurated life of the incoming Kingdom of God.

$\mathrm{RC}$ creation theology, correlatively, reconstructs a creation sacramentalism in dialogue with the doctrine of the Eucharist and transubstantiation. Undoubtedly, sacramental theology is central to RC liturgy and has been connected for some time to this ecological motif. ${ }^{119}$ In the Eucharist, the church as the people of God are free through the salvation of Christ as mediated through the bread and wine. In a mysterious sense, the bread and wine as the body and blood of Christ represent the larger creative order where Jesus partners with suffering with the oppressed universe. This has come to be called, in the words of Al Fritsch, a Eucharistic ecology. ${ }^{120}$ This present and visceral "Eucharistic world" is a world open to wonder, grace, and the majesty of God's divine presence. ${ }^{121}$ And as the presence of God is made manifest within the confines of the Lord's supper in the Mass, so is it present in creation allowing all human agents the freedom to experience an experiential participation with transcendent God. Both Eucharist and creation, in iconic fashion, become real windows through which humans can experience the divine

\footnotetext{
${ }^{118}$ Christine Hinze, "Catholic Social Teaching and Ecological Ethics," in And God Saw That It Was Good, eds. Drew Christiansen and Walter Grazer (Washington, DC: United States Catholic Conference, 1996), 165-182 (170-171).

119 Of course, the Eucharist is one of seven church sacraments practiced within the RC tradition. Interestingly, the practice of the Eucharist and the doctrine of transubstantiation have been open doors for RC ecotheological imagination. Michael Himes and Kenneth Himes, "The Sacrament of Creation: Toward an Environmental Theology," in Readings in Ecology and Feminist Theology (Kansas City: Sheed \& Ward, 1995), 270-283.

${ }^{120}$ Albert Fritsch, “Appropriate Technology and Healing the Earth,” eds. Albert LaChance and John Carrol, Embracing Earth: Catholic Approaches to Ecology (Maryknoll: Orbis, 1994), 96-114.

${ }^{121}$ Charles Cummings, Eco-Spirituality: Toward a Reverent Life (Mahwah: Paulist, 1991), 37.
} 
community. Through this, the tangible and touchable Eucharist of creation is the experience of the elemental divinity, the finitum capax infiniti- "the finite has the capacity for the infinite." 122 Love for the cosmos, appropriately and logically, parallels Christ's love that liberates the Church and creation through death and resurrection on the cross.

Secondly, as we have seen with the creation theology motif, RC ecotheology has strong undertones that reassess the integrity and dignity of the earth or what has been called the dignitas terrea ("dignity of the earth"). This is perhaps best illustrated in Charles Murphy's RC green ethic based on a humiliates (humility) towards creation. ${ }^{123}$ In Murphy's framework, similar to the creation theology motif, humanity has lost an essential perspective of wonder towards the earth. Concurrent with this lost perspective of wonder and dignity has emerged a controlling and overbearing relationship to the creative order. Because of this, humans, with their controlling and domineering praxis, have moved from tending the garden to running it. ${ }^{124}$ Murphy suggests the way forward is through a necessary turn once again to the mystery, wonder, and enigmatic creation narrative that shines the mysterious glory of God's being.

\footnotetext{
${ }^{122}$ I am indebted to Douglas Hall for introducing me to this concept in his seminal study on the idea of stewardship inherent throughout the Judeo-Christian scriptures. Douglas Hall, The Steward: A Biblical Symbol Come of Age (Grand Rapids: Eerdmans, 1990), 139.

123 Charles Murphy, At Home on Earth: Foundations for a Catholic Ethic of the Environment (New York: Crossroad, 1989), 128. John Haught's differentiates ecotheology into three main approaches: the apologetic, the sacramental, and the eschatological. Murphy's work fits largely within the first. Within this framework, Haught rather critically challenges the overtly "apologetic" nature of RC ecotheology, which at times uses the Scriptures to sort of prove the "natural" nature of the Bible while overlooking "passages in the early Christian and other theological writings" that are equally as edifying. John Haught, The Promise of Nature: Ecology and Cosmic Purpose (Mahwah: Paulist, 1993).

124 I borrow this clever wording from Eugene Peterson, Under the Unpredictable Plant: An Exploration in Vocational Holiness (Grand Rapids: Eerdmans, 1992), 7.
} 
Broadly, this turn evidenced in Murphy's work has a pneumatological thrust emerging from the widespread and growing regard by RC academic and lay theologians to the role of the Spirit in Trinitarian theology in the most recent half a century. ${ }^{125}$ This shift towards pneumatology has given ecotheology of the Spirit a more prominent role, shifting RC theology to more robust discussions on the overall landscape of the Holy Spirit in creation. This is evidenced in a number of concilliar documents. For instance, the language of Vatican II statements includes an astonishing 258 references to the Holy Spirit, by far more than any other RC document in history to date. ${ }^{126}$ Similarly, the entire year of 1999 was devoted to the Holy Spirit in the RC liturgical year. With this emphatic turn to the Spirit came an enhanced look at the Spirit's mission and role in the creation story. The Spirit is therefore imagined as incorporating the overarching mission of returning the voice to the voiceless, including creation, which connects missionality of the Spirit to creation. ${ }^{127}$ Clearly, on a broader level, this pneumatological missional thrust is played out predominately in the various RC liberation theologies. Leonardo Boff likewise addresses this pneumatological creation in terms of the Spirit who is Spiritus ubique diffuses - "the Spirit diffused in all"- throughout the entire creation. Such ubiquitous pneumatological emphasis has played a key role in returning a sense of spiritual dignity to creation, where God loves the entire cosmos and fills the entire cosmos through his Spirit.

\footnotetext{
${ }^{125}$ While the reasons for these pneumatological shifts are not universally agreed upon, two continue to be suggested. To begin, Vatican II language regarding the Spirit was prominent beyond previous RC documents, including the Lumen Gentium. And, as well, the growing dialogue regarding the theologies of religions has forced much attention to the Spirit at work in the world perhaps through the influence of RC charismatic movements, Pentecostalism, and other similar movements.

${ }^{126}$ José Comblin, The Holy Spirit and Liberation (Maryknoll: Orbis, 1989).

${ }^{127}$ Leonardo Boff and Clodovis Boff, Salvation and Liberation (Maryknoll: Orbis, 1984); Leonardo Boff and John Cumming, Ecology and Liberation: A New Paradigm (Maryknoll: Orbis, 1995), 50.
} 
Cosmologically speaking, the force of this turn to creational pneumatology certainly finds its roots in the depths of historic RC theology. Salvific modes of the Spirit's life flow when humanity willingly returns to a sense of holy mystery within creation ultimately leading to a renewal of human perceptions regarding the broader created order. Truly, the Holy Spirit has, since Vatican II and Pope Leo XIII's encyclical On the Holy Spirit, played an enhanced role in the RC tradition. ${ }^{128}$ In this setting, Yves Congar's pneumatological vision in postconcilliar RC theology has been so readily accepted as opening the way for new and fresh views of the creation in regards to the Holy Spirit therein, while almost categorically stressing the apophatic tradition, giving carte blanche preference to mystery-centered creation found often in creation theology. ${ }^{129}$ Where the Spirit resides, there is the mystery of God. While it is not uncommon to see an ecotheological approach formulated from a Christological or eschatological paradigm, these pneumatological approaches have been becoming much more prominent focusing on the Holy Spirit's work in the present world. ${ }^{130}$ Karl Rahner's ecclesiological vision of the church "as the continued incarnation," continuing Christ's redemptive administration, suggested that the salvation of the entire world is an important theological motif alongside the church's redemption. Rahner posited that each person is a "spirit-in-theworld," who, along with creation, would experience eternal salvation together. This

\footnotetext{
${ }^{128}$ Edward O'Connor, "The Hidden Roots of the Charismatic Renewal in the Catholic Church," in Aspects of Pentecostal-Charismatic Origins, ed. Vinson Synan (Plainfield: Logos International, 1975), 169-191 (171-172).

${ }^{129}$ Yves Congar, I Believe in the Holy Spirit, 3 vols. (New York: Crossroad Publishing, 2001).

${ }^{130}$ For an interesting Christological approach towards creation issues, see Carrol's discussion on "Christ the Ecologist" in his John Carrol and Albert LaChance, Embracing Earth: Catholic Approaches to Ecology (Maryknoll: Orbis, 1994), 30-34.
} 
salvation is to be had by human and nonhuman realities in tandem with one another. ${ }^{131}$

Rahner's approach leaves the door wide open to engage the ecclesiological role in creation care, appearing as well to be steadily open to rich pneumatological possibilities in regards to a pneumatology of the earth. This pneumatological strain of creation theology has a strong track record amongst RC theology going back to Hildegard of Bingen's "Greening of the Spirit," which sought to formulate a "greening of the church" and a broader vision of ecocare and respect. ${ }^{132}$

These pneumatological turnings towards the integrity of creation have been undeniably equaled by the Christological shifts of Teilhard de Chardin who is still championed by many as a father of RC ecotheology. Chardin, who spoke of Christ as the Christosphere, utilized global and ecological language to develop a more cosmic Christology. ${ }^{133}$ For Chardin, earth has dignity simply because the post resurrection Christ embodies the entire cosmos. Chardin's "spirituality of life" continues to play a key function in RC ecotheology, undeniably more so following his death than during his life. "Nothing below is profane," Chardin writes, arguing that the dualistic quagmire prevalent in much RC theology that envisions matter as inherently evil must become antiquated or

\footnotetext{
${ }^{131}$ Karl Rahner, Foundations of Christian Faith (New York: Seabury Press, 1978), 151-152. See also Leo O'Donovan, A World of Grace: An Introduction to the Themes and Foundations of Karl Rahner's Theology (New York: Seabury, 1980).

${ }^{132}$ Barbara Newman, Sister of Wisdom: St Hildegard's Theology of the Feminine (Berkeley: University of California Press, 1997). For an extended look at Hildegard's idea of the "greening of the Spirit" and its implications pneumatologically, see Kärkkäinen, Pneumatology: The Holy Spirit in Ecumenical, International and Contextual Perspective.

${ }^{133}$ This observation is made by Doran McCarty, Teilhard De Chardin, Makers of the Modern Theological Mind (Waco: Word Books, 1976). For helpful overviews of Chardin's thought as it pertains to ecotheology, see Celia Deane-Drummond, Pierre Teilhard De Chardin on People and Planet (London: Equinox, 2006); Louis Savary, Teilhard De Chardin, the Divine Milieu Explained: A Spirituality for the 21st Century (New York: Paulist, 2007).
} 
theology fails itself. ${ }^{134}$ Chardin's later Man's Place in Nature and The Phenomenon of Man, published posthumously, showed that a major formation of his own thinking centered on Christ as the Universal One, or the Cosmic Christ in all of creation. ${ }^{135}$ While his Phenomenon of Man caused significant controversy, it clearly demonstrates the evolution of his theological thought as he argues the development of all creation to what he called the "Omega Point," a point in history when all evolutionary process will come to completion that reflected a similar paradigm to Whiteheadian process thought of the culmination of all things. It is then that God is revealed as the God in quo omnia constant — “in whom all things hold together." This cosmic Christology leads to a Christcentered creation, one in God's salvation that continues to work itself out until the culmination of all things. In fact, throughout Chardin's writings, the universal Christ and Cosmic Christ are widely interchangeably connected. ${ }^{136}$

The late Thomas Berry has long been received as the most recognized carrier of Teilhard de Chardin's theological mantle. ${ }^{137}$ In Berry's Dream of the Earth, he addresses the numinous qualities of creation, the spiritual and hallow dimension of all life on this sacred earth. ${ }^{138}$ This is similarly represented in his later New Cosmology. ${ }^{139}$ Conceptually,

\footnotetext{
134 Pierre Teilhard de Chardin, The Divine Milieu (Portland: Sussex Academic, 2004), 24, 64-70.

${ }^{135}$ Pierre Teilhard de Chardin, The Phenomenon of Man (New York: Harper, 1959); Pierre Teilhard de Chardin, Man's Place in Nature (New York: Harper \& Row, 1966). In another formative cosmo-ecological text, Chardin recalls an ecstatic experience in the desert by which he was unable to receive the Eucharist and asked God to give him a sacrament in its place. Thus his "Eucharistic cosmology" of the Universe was birthed. Pierre Teilhard de Chardin, Hymn of the Universe (New York: Harper \& Row, 1965).

${ }^{136}$ Teilhard de Chardin, The Divine Milieu, 19.

${ }^{137}$ For an in-depth discussion on Berry's theology in a dialogical format, see Anne Lonergan and Caroline Richards, Thomas Berry and the New Cosmology (Mystic: Twenty-Third Publications, 1987).

${ }^{138}$ Thomas Berry, The Dream of the Earth (San Francisco: Sierra Club Books 2006). Denis Edwards envisions a similar strain of respectfulness towards the integrity of creation and the human person, drawing heavily on the theology of Karl Rahner's work. See Edwards, Jesus and the Cosmos, 112-116.

${ }^{139}$ Thomas Berry et. al., Thomas Berry and the New Cosmology (Mystic: Twenty-Third Publications, 1987).
} 
the numinous creation discussed within is similar to the anima mundi or "soul of the world" concept found in animistic worldviews such as the First Nation people and Eastern animism of which we have examined. One of the keys to comprehending Berry and a large part of the chorus of $\mathrm{RC}$ scholarship is a large-scale reorientation of salvation from an "end-of-life" experience to "mid-life" participation based on a reconsidered contemporary eschatological emphasis. But this new cosmological experience is redemptively possible only if humanity can synthesize science and faith in what Berry calls a new cosmological "story" based on eschatological grounds. ${ }^{140}$ While this has become somewhat theologically faddish with a renewed emphasis on Kingdom discourse ("present, not yet" theologies) within Protestantism, it has been a long withstanding staple in much of the RC tradition. It argues that a view of salvation overly concerned with the future will neglect the pressing needs of today; even ecological needs. In speaking of this, Berry quips, "If we look up to the sky too much, we might trip." ${ }^{141}$ This, ultimately, has been an ecological result of a far-off eschatology. For Berry, salvation need not wait far off, but salvation remains present and current, lived out today, and must include healing of the created order. His popularity is no doubt a result of his bringing of the broader theological discussion to more lay and popular levels through his writings. ${ }^{142}$

Similarly, this idea of the dignitas terrea captures a deeper respect for the soul of life - the anima mundi - the soul within each living creature. ${ }^{143}$ While the idea of anima mundi found in animistic worldviews is nothing new, being a staple of medieval

\footnotetext{
140 Berry, The Dream of the Earth.

141 Berry, The Dream of the Earth, 122.

142 Thomas Berry et. al., Befriending the Earth: A Theology of Reconciliation between Humans and the Earth (Mystic: Twenty-Third Publications, 1991).

143 Anima Mundi is Latin for "soul of the earth" and was used often, and perhaps first, by the Stoics.
} 
European philosophical thought, it has been revitalized on a more contemporary scene to recapture the sense of the divine in creation. It is possible these ideas went through massive changes during the times of the Protestant reformation because of its seeming connection to pagan theories of the earth. ${ }^{144}$ On a contemporary level, nontheists such as E.O. Wilson often utilize similar language referring to a particular beings "vitalism." 145 Drawing on this, Panikkar pays attention to this concept of the anima mundi in his establishment of a cosmotheandric theology, ${ }^{146}$ as does Thomas Berry giving expression to Jung's central theme of anima. ${ }^{147}$ Thomas Berry connects the ecological crisis, as do others in the field, as a crisis in theology by virtue of a human unwillingness to see the soul in all beings, especially in Western cosmology. Berry writes, "To wantonly destroy a living species is to silence forever a divine voice." ${ }^{\not 148}$ Berry furthers this by suggesting that this unwillingness, when destroying the images of God in species, destroys God's self-revelation. And when this takes place, a piece of the divine picture is unalterably lost.

We have sketched both creation theology and what we have called the dignitas terrea strain in RC ecotheology. Finally, we will now turn to liberation theology as a prominent stream in $\mathrm{RC}$ ecotheology paralleling other contextual movements such as

\footnotetext{
${ }^{144}$ While I agree the Protestant Reformation did little to give voice to the idea of the anima mundi of all created beings, I do not go as far to say it was due to the Church's attempt to silence paganism, as does Rupert Sheldrake in Fox and Sheldrake, Natural Grace: Dialogues on Creation, Darkness, and the Soul in Spirituality and Science. Nevertheless, it is difficult to not see a trend of "desacralized nature" in the Protestant Reformation. Work has yet to be done on the proliferation of sacred space in Reformation movements and the "desacralization" of the Earth. For a criticism of Reformation thought on nature, see Rupert Sheldrake, The Rebirth of Nature: The Greening of Science and God (Rochester: Inner Traditions, 1994).

145 Berry, The Dream of the Earth.

${ }^{146}$ Panikkar and Eastham, The Cosmotheandric Experience, 137-152.

${ }^{147}$ Berry and Tucker, Evening Thoughts.

${ }^{148}$ Berry, The Dream of the Earth, 46.
} 
Korean Minjung theology, Feminist liberation theology, and Black liberation theology in the U.K. and North America. While there has yet to be a truly exhaustive synthesis of a liberation theology and ecological care, or "ecoliberation theology," a number of preliminary works have been generated that can help illustrate its theological position. ${ }^{149}$ This general emphasis of care for the land, highlighting ethical treatments of land, animals, and creation in general, which Aldo Leopold famously called the "land ethic," focuses our attention to the relationship humanity has to the responsibility of ethically caring for creation. ${ }^{150}$ What we find here is a sort of incarnational ethic that can exist between the two compelling narratives of science and the Bible, an unnecessary dualism described by Thomas Berry in his Dream of the Earth ${ }^{151}$ Incarnational life—living among and alongside the oppressed (including the poor) earth—allows humans to live life ethically for the regeneration of the earth because of their awakened presence to the pain of creation. For it is being alive amidst, what Aldo Leopold calls the "world of wounds," that allows us to incarnate change for a more liberated earth. ${ }^{152}$

This is represented perhaps no better than in the liberation theology of Leonardo Boff who constructs a novel synthesis of liberation theology and theology of the land. Two of Boff's major works on the subject—Ecology and Liberation and Ecology and Poverty — have suggested a liberation theology that reformulates theology to be done in

\footnotetext{
${ }^{149}$ For an approachable examination of ecoliberation theology, see Sallie McFague, Life Abundant: Rethinking Theology and Economy for a Planet in Peril (Minneapolis: Fortress, 2001).

${ }^{150}$ Aldo Leopold, A Sand County Almanac (New York: Ballentine, 1970), 47.

${ }^{151}$ I am indebted to Mary Evelyn Tucker for this observation in the introduction to Berry's text. Berry and Tucker, Evening Thoughts: Reflecting on Earth as Sacred Community, 10. A similar model of incarnational ecology from an Anglican framework is found in Martha Kirkpatrick, "For God So Loved the World: An Incarnational Ecology," ATR 91.2 (2007), 191-212. For a helpful overview of dualism (especially in American religion) as the grandchild of Gnosticism, considered by some as a sort of neo-Gnosticism, see Harold Bloom, The American Religion (New York: Simon and Shuster, 1992).

${ }^{152}$ Leopold, A Sand County Almanac, 197.
} 
ecological terms. ${ }^{153}$ Using the liberation theologies of South America as the launch pad of his exercise, Boff reconstitutes an ecological vision in liberation terms and argues for a "liberation-centered" creation care approach that arises once again from a return to the mystical element of creation. ${ }^{154}$ Boff, although excommunicated from the RC tradition as of now, continues to play a key role in reimagining ecotheology from a liberation perspective. This requires a new way at looking at things - a liberation way. In earlier writings, Boff suggests we must see salvation with "two eyes...one looks back toward the past, where salvation broke in; the other looks toward the present where salvation becomes reality here and now." ${ }^{, 155}$ Then, in the context of Christ's salvation and redemption, today's earth can experience new life and reconciliation to humanity. While liberation theology has given Third World peoples a workable theological framework to develop avenues of praxis-centered Christianity in the midst of radical oppression, it continues to give new fuel to the ecotheological discussions especially within, but not relegated to RC. ${ }^{156}$ It points to a God that runs to the oppressed, finds and embraces them in their need, and incarnates life among them; including the entire oppressed creation. For it is among the squandered and forgotten creation, in the words of Boff, where "God is truly God only as the God of those who are shut out." ${ }^{, 157}$ Salvation in Christ is therefore emblematic of the salvation the earth will experience as he is found among the oppressed creation.

\footnotetext{
${ }^{153}$ Boff and Cumming, Ecology and Liberation; Leonardo Boff and Virgil Elizondo, Ecology and Poverty: Cry of the Earth, Cry of the Poor (Maryknoll: Orbis, 1995).

${ }^{154}$ Boff and Cumming, Ecology and Liberation, 139.

${ }^{155}$ Leonardo Boff, Way of the Cross: Way of Justice (Maryknoll: Orbis, 1986), viii.

${ }^{156}$ As a comparative example, for a non-RC approach to liberation ecotheology, see Ulrich Duchrow and Gerhard Liedke, Shalom: Biblical Perspectives on Creation, Justice and Peace (Geneva: WCC Publications, 1989), 47-75.

${ }^{157}$ Boff and Cumming, Ecology and Liberation, 181.
} 
At the end of the day, liberation ecotheology offers a much-needed critique and reconstruction of oppressive Western language that inherently devalues creation that arises from a linguistic arrogance. Responding to Enlightenment dualism that has helped proliferate the "devitalization of the planet" has been the daunting task of ecotheology at large in this late modern time. ${ }^{158} \mathrm{~A}$ fraction of this critique focuses on human language regarding creation, suggesting it has led to a theological cosmos of, in Charles Cummings words, "a world without wonder." 159 Because humans have lost respect, awe, and wonder for what is the creational holy mystery, a renewal in language is a most important task. Creation theology reminds us the earth is not a machine. But in order to understand this, we must live among creation embedded in its life. Humanity must be in contact with the world. This is the force behind Thomas Berry and Brian Swimme's thesis that linguisticcultural perspectives are deeply central to theological discourse. Words shape theology and ecological praxis. For how one "names" creation can demean and bemoan creation in powerful ways, essentially stealing its mystery. What is needed is a new story-a return to mystery. ${ }^{160}$ This thesis undoubtedly comes on the heels of linguistic criticisms of the likes of the early late modern exegetes Derrida and Sartre, as well as continental existential philosophy at large, seeking to usurp power structures implied in linguistic

\footnotetext{
158 Berry and Tucker, Evening Thoughts, 18.

${ }^{159}$ Charles Cummings is a prime example of such anti-Western reaction, with criticisms of the epistemological and philosophical worldviews of Descartes, Newton, and Darwin. Descartes famously noted in his view that the universe was no more than "mind and mechanism" and that "man is Lord and owner of nature."

160 Brian Swimme's suggests that "the Universe is a Green Dragon," critiquing human tendency to undermine the mysterious nature of creation by giving it a name. Inspired by the words of Thomas Berry, this work offers a transscientific/theological cosmology. Brian Swimme, The Universe Is a Green Dragon: A Cosmic Creation Story (Santa Fe: Bear Press, 1985).
} 
discourse. Similarly, a RC priest and ecotheological thinker writes a prime example of $\mathrm{RC}$ ecoethics, paying regard to the church's liberative role in the global crisis. ${ }^{161}$

Finally, while able to be mentioned in the ecofeminist typology, we must mention the work of particular RC ecofeminists whose purposes are similar to liberation theology. If liberation is going to be found for creation, it must initially begin in the healing of our language. What is needed is language liberation from man-centered, human-centered language categories with which humans commonly utilize. This is seen in the prolific work of RC Elizabeth Johnson in She Who Is, which attempts to turn anthropocentric (man-centered) theological language about God and creation on its head for the purposes of ecological and female liberation. ${ }^{162}$ Johnson's strength remains in that while critical of her own tradition she continues to practice within it. Her vision advocates heavily, for what we could call a kinship model imagining a multispecies chorus of equality before the God of creation. ${ }^{163}$ Much RC liberation theology is similar in tone, critical of the RC tradition. Johnson's basic argument parallels that of Sallie McFague in that our very theological model, or view of God and his (or her) creation, "shapes our living in his light." ${ }^{\prime 164}$ Johnson argues elsewhere that we cannot get to the bottom of the ecological crisis until we get to the bottom of the sexist crisis because Western language undermines

\footnotetext{
${ }^{161}$ Sean McDonagh, Passion for the Earth (Maryknoll: Orbis, 1994).

162 Elizabeth Johnson, She Who Is: The Mystery of God in Feminist Theological Discourse (New York: Crossroad, 1997).

${ }^{163}$ Johnson writes, "Woven into our lives is the very fire from the stars and the genes from the sea creatures, and everyone, utterly everyone, is kin in the radiant tapestry of being." Elizabeth Johnson, Women, Earth, and Creator Spirit (New York: Paulist, 1993), 39.

${ }^{164}$ Johnson, She Who Is, 39. I am reminded of a phrase heard years ago (of which I am not remembering the speaker), which says, "We all live up to the story we live under." The nature of "shared narrative" plays crucially in creation-care practice. In many ways, our shared story of creation will ultimately determine our relationship to it.
} 
both. ${ }^{165}$ These linguistic critiques are very important in formulating the language frameworks of how we talk about creation.

\subsection{Orthodox Ecotheology $y^{166}$}

We turn now to the Orthodox tradition to examine their representative ecotheology. Having been theologically enriched through its incredibly diverse set of traditions and settings, the Orthodox communion will continue to play in the near future a much more influential role ecotheologically as the ecclesia universalis seeks breadth that can be informed by all voices from amongst the church. Perhaps more than in the West, Eastern Christian traditions (e.g. Orthodoxy) have developed an ecological ethos regarding the care of the land through Jainism and Buddhism. And the Orthodox communion has similarly formed an ecological conversation that brings a thoughtful critique to the West. Recently, the Ecumenical Patriarch and the autocephalous Church of Greece, with significant interest initially given by the Patriarch Dimitrios I (1972-1991), have played key roles in this ecological resurgence. Having prominent Eastern roots, the Orthodox tradition proposes a formidable ecotheology based primarily on communion and interrelationality of the creational order. Yet, at the same time, we still await a fully systematic Orthodox theology of creation. Since a full Orthodox ecotheology has not been produced, what remains are bits and pieces that will accommodate our project to

\footnotetext{
165 Johnson, Women, Earth, and Creator Spirit, 10.

${ }^{166}$ I refrain from using the term "Eastern Orthodoxy" by virtue of the diversity geographically and theologically within the Orthodox tradition. While historically very Eastern geographically, it has of recent become much more prevalent in North America, as elsewhere.
} 
understand a growing tradition as opposed to an established one. What does an Orthodox ecotheology propose?

The proposed theme during the General Council of the WCC at Canberra in 1991 was "Come Holy Spirit, Renew the Whole Creation." ${ }^{167}$ For many observers this council was a watershed in the church's response to the ecological crisis. Although, clearly, the fruit from this work had been planted earlier in previous sessions. Earlier, the sixth assembly of the WCC in Vancouver, Canada (1982), gave focused attention to "justice, peace, and the integrity of all creation" $" 168$ while in many ways laying the groundwork for further ecological discussion on an ecumenical level. Following Vancouver, in response, the Orthodox communion in 1987 intervened an inter-Orthodox Consultation on Orthodox Perspectives on Creation in Sofi (Bulgaria) regarding the issues raised at the ecumenical council. Two years later, in 1989 at Ligonier, Pennsylvania, a similar symposium on the ecological crisis gathered. Following these meetings, the Orthodox added a yearly feast that has been scheduled on September first of every year "for the Protection of the Environment." Since 1999, an Orthodox School of Theology on the Greek island of Halki has been established to continue ecological discussions on these issues for Orthodox pupils. Beyond this, there were many results from these gatherings including lay-level works helping give Orthodox community’s tangible ways to assist. ${ }^{169}$ Later, the patriarch Bartholomew, on the day of the Protection of the Environment,

\footnotetext{
167 David Kerr, "Come Holy Spirit--Renew the Whole Creation": The Canberra Assembly and Issues of Mission," IBMR 15.1 (1991), 98-103

168 http://www.wcc-coe.org/wcc/what/jpc/index-e.html, (accessed August 25, 2008). For an overview of biblical perspectives and reflection on Vancouver's significance, see Duchrow and Liedke, Shalom.

${ }^{169}$ For a lay-level work on how the Orthodox are attempting to live out a praxis-centered ecology, see D. Oikonomou and Alexander Belopopsky, Orthodoxy and Ecology: Resource Book (Bialystok: Syndesmos the World Fellowship of Orthodox Youth, 1996).
} 
September 1,2008, wrote a significant encyclical to the Orthodox communion regarding theological and practical updates in relation to their care of the earth. ${ }^{170}$ This particular text gives significant credence to the scientific work on ecological demise. Similarly, the encyclical calls for ecological symposia which deal with climate change and the management of water. Theologically, significant ecological blame has been placed on human sinfulness for this growing crisis. The Orthodox position emphasizes that the creation participated in the fall of Adam and thus reaps the consequences of the fall even on an ecological level.

Orthodox ecotheology thus tends to emphasize the sin-centered nature of ecological depravation. ${ }^{171}$ Ecological blame for the destruction of creation is placed largely on the depravity of human sinfulness (depravity-centered) with a necessary correction initiated with a changed heart and mind (metanoia-centered). The formulated theological conclusions have given attention to the redemption of the human personhood as the beginning of a new creation where the liberated liberate. Vincent Rossi writes, "Creation is raised and transfigured as the individual is raised and transfigured...the life of Christ exemplifies the love which we are called to give in redeeming creation." ${ }^{172}$ Viewed Christologically, this parallels much of Moltmann's kenotic creational theme. ${ }^{173}$

\footnotetext{
170 On the "Green Bartholomew" and his theology, see Bartholomew and John Chryssavgis, Cosmic Grace + Humble Prayer: The Ecological Vision of the Green Patriarch Bartholomew I (Grand Rapids: Eerdmans, 2003).

${ }^{171}$ For a more recent text on the Orthodox care of the environment see http://www.ecpatr.org/docdisplay.php?lang=en\&id=970\&tla=en, (accessed August 21, 2008).

${ }^{172}$ Vincent Rossi, "For the Transfiguration of Nature: Papers from the Symposium on Orthodoxy and Ecology," EPI 10 (1990), 7-74 (73).

${ }^{173}$ For an excellent overview of the kenotic theme, or God's "self-emptying" see John Polkinghorne, The Work of Love: Creation as Kenosis (Grand Rapids: Eerdmans, 2001). See also his John Polkinghorne, One World: The Interaction of Science and Theology (Princeton: Princeton University Press, 1986); John Polkinghorne, Science and Creation: The Search for Understanding (London: SPCK, 1988); John
} 
Soteriologically, the cosmological order is redeemed with and through Christ's death on the cross and later resurrection. In this context, Orthodox Paulos Gregorios writes, "Human redemption is inseparable from the redemption of time and space as well as of 'things." "174 This emphasis on holistic soteriology, or the redemption of all the cosmos, is continually encountered throughout Orthodox ecological literature and offers a healthy corrective to Protestant soteriological models that focus primarily on the salvation of the individual. Similarly, as a form of holistic soteriology, creation is being prepared for an eventual reconciliation with God and itself through apokatastasis, the "fulfillment" at the end of time. Culmination of the creation in this way finds its roots in the theology of Origen and has been reformulated for green theology to include the entirety of the cosmos on a contemporary basis. ${ }^{175}$

John Zizioulas's koinonia theology, as well, incorporates some dramatic ecological implications. His Being as Communion proposes an Orthodox ontology for the ecclesial community with specific regard to the imaginative metaphor of communion. ${ }^{176}$ While not explicitly dealing with ecological issues in this particular text, Zizioulas's usage of the communion image offers an accommodating theme for ecotheology. The human task, of existence in community (koinonia), is to live harmoniously with humanity

Polkinghorne, Quantum Physics and Theology: An Unexpected Kinship (New Haven: Yale University Press, 2007).

${ }^{174}$ Paulos Mar Gregorios, The Human Presence: An Orthodox View of Nature (Geneva: WCC Publications, 1978), 81, (italics mine).

${ }^{175}$ For a further discussion on the Orthodox idea of apokatastasis with possible ecological implications, see Paulos Mar Gregorios, "New Testament Foundations for Understanding the Creation," in Liberating Life, eds. Charles Birch, William Eakin, and Jay McDaniels (Maryknoll: Orbis, 1994), 83-92; Kusumita Pedersen, "Inclusion and Exclusion: Reflections on Moral Community and Salvation," in Earth Habitat, eds. Dieter Hessel and Larry Rasmussen (Minneapolis: Fortress, 2001), 33-52 (44-46).

${ }^{176}$ John Zizioulas, Being as Communion: Studies in Personhood and the Church (London: Darton Longman \& Todd, 2004). 
and creation. As God's creatures, we serve God and his creation. The late Patriarch Dimitrios who reportedly prayed to God on behalf of creation, mirrors this, saying, "Thine own of Thine own we offer unto thee."177 Thus, on God's behalf, we serve his community of creation. Zizioulas's subsequent work in Communion and Otherness gives similar attention to connecting his communion emphasis to the natural order. ${ }^{178}$ Communion with creation is the continual process of offering back to God that which God has given humanity to steward. Ecological ethics, in this light, is birthed out of the dialogical tension of stewardship and relationship. This communion theology based on harmony emphasizes the mystery of God in creation, not to mention its use of apophatic theology and images of God critiquing human attempts to master the mystery of creation. ${ }^{179}$

It seems to be clear that these particular themes reserve for earth a necessary element of mystery. In essence, creation becomes a lens through which we see God. We could say that the Orthodox perspective argues iconic thinking towards creation. While the Orthodox community has consistently emphasized the worship of God through icons and symbols, the practice of envisioning creation as iconic leaves open very intriguing and thoughtful possibilities in the green dialogue. This sacramentalism of seeing God through created entities is what John Carmody calls a natural "manifestation of the

\footnotetext{
${ }^{177}$ Milton Efthimiou, "Orthodoxy and the Ecological Crisis," in Ecotheology, ed. David Hallman (Maryknoll: Orbis, 1994), 92-95 (92).

178 John Zizioulas, Communion and Otherness: Further Studies in Personhood and the Church (London: T\&T Clark, 2006).

${ }^{179}$ On the mystical strain in the Orthodox tradition, see Vladimir Lossky, The Mystical Theology of the Eastern Church (London: James Clarke, 2005).
} 
divine." ${ }^{" 180}$ This theological strain, seen in RC ecotheology as well, views "each creature [as] a unique manifestation of the creator, a sacrament of the invisible God." ${ }^{\prime 181}$ One scholar, speaking of this sacramentalism, noted that, "like the incense that spreads to each corner of an Orthodox church, the spiritual power of the holy God spread to each corner of the universe." ${ }^{\prime 182}$ To live a life of harmony, not only in religious forms, but praxisoriented towards created life, honors creation and allows us to live out God's Trinitarian communion, to borrow the phrasing of Zizioulas.

In the setting of the creation crisis, ecological repentance (metanoia) has become the Orthodox imperative. Because all human beings are seen as priests of creation, it is the human responsibility to change the way they live their life to better steward God's land. ${ }^{183}$ To live rightly among the earth is to practice what St. Maximos the Confessor called the "cosmic liturgy." 184 It is a return to the perichoretic dance of the Trinity. This perichoretic Trinitarian model invites each human to the dance of the Trinity, which dances with and alongside the entire creation. The human being is therefore seen as a more acute version of the larger cosmos, which is quite different from Western paradigms that refuse to view humanity as a part of nature. Thus, to care for the human being is to care for the entirety of the earth. The Orthodox position gives expression to the difference between the microcosm and the macrocosm, the larger and smaller cosmos. This echoes

\footnotetext{
${ }^{180}$ John Carmody, Ecology and Religion: Toward a New Christian Theology of Nature (New York: Paulist, 1983), 76.

${ }^{181}$ Cummings, Eco-Spirituality, 36-37. For a helpful article devoted to the topic of sacramental approach to environmental issues, see John Habgood, "A Sacramental Approach to Environmental Issues," in Liberating Life, eds. Charles Birch, William Eakin, and Jay McDaniels (Maryknoll: Orbis, 1990), 46-53.

${ }^{182}$ Carmody, Ecology and Religion, 76.

${ }^{183}$ As quoted by Zizioulas in his introduction to Bartholomew and Chryssavgis, Cosmic Grace + Humble Prayer.

${ }^{184}$ Gottlieb, This Sacred Earth, 228.
} 
Gregory of Nazianzus (329-389) who argued that human beings are "a second cosmos, a great universe within a little one." ${ }^{185}$ Yet at the same time, in the phrasing of the Greek fathers, humans have fallen into what has been called a bout of "self-love," which is love for human self over and above the remainder of God's creation. The Greek Fathers called this love philaotia. ${ }^{186}$ Therefore, a focus on personal transformation and community brings a rich focus to ecotheological discussions.

\subsection{Protestant Ecotheology}

Protestant ecotheology is an important area of study for comprehending a Christian theology of creation. Martin Luther (1483-1546), the father of the Protestant Reformation, once wrote, "To believe in God the Creator means to believe that he created me along with all other created beings. Few have progressed so far as to believe this in the fullest sense." ${ }^{187}$ We now turn to examine how the successors of this movement- the Protestants - have progressed in their vision of creational theology. How have Protestants theologically situated themselves in the midst of what Protestant John Cobb calls the “systematic degradation of creation"? ${ }^{188}$ Historically speaking, Protestant theology has undergone significant revision in the post-Enlightenment era since both Kant (17241804) and Schleiermacher (1768-1834) radically shook its epistemological foundations,

\footnotetext{
185 Grant Gillett and Arthur Peacocke, Persons and Personality: A Contemporary Enquiry, vol. 1 (Oxford: Basil Blackwell, 1987), 203.

186 See Efthimiou, "Orthodoxy and the Ecological Crisis," 95.

187 Quoted in D. J. A Clines, Job 1-20, Word Biblical Commentary, vol. 17 (Waco: Word, 1989), 248.

188 John Cobb, Sustaining the Common Good: A Christian Perspective on the Global Economy (Cleveland: Pilgrim Press, 1994), 1.
} 
with its theology going through similar revisions today. ${ }^{189}$ Since Kant's Religion within the Limits of Reason Alone (1793) surmised that Christianity's significance was moral rather than theological/dogmatic, Protestantism has been forced to reenvision its overall methodology. ${ }^{190}$ Even more so, a post-Hegelian critique of the doctrinal connection to the historical metaphysics (e.g., crucifixion, resurrection, creation narratives), found in such texts as Hegel's Lectures on the Philosophy of Religion, has often replaced the doctrinal in philosophic inquiry. ${ }^{191}$ Once this doctrinal deconstruction had begun, it put into question the role creation narratives play in informing ecological care. For if the book of Genesis cannot be historically trusted as we had previously thought, why then should it be doctrinally or theologically trusted? This and other problematic issues have shaped and developed twenty-first century Protestant ecotheology.

More recently, postliberal Protestant theology has catapulted a cultural-linguistic doctrinal understanding on the scene as differentiated from propositional and experiential-expressive frameworks. This has made room for a more creative approach to theological construction. Lindbeck and the Yale school have emphasized narrative theology, paving the way for a more progressive synthesis and making ecological discussion in these Protestant circles much more palpable ${ }^{192}$ But the cry of late modern deconstructionism, with its critiques of the ideas of wilderness, to postcolonial ecologies, to biocentrism in an age of AIDS, have seemingly superseded a truly biblical response to

\footnotetext{
${ }^{189}$ Friedrich Schleiermacher, The Christian Faith, trans., H.R. Mackintosh and J.S. Stewart (New York: Charles Scribner's Sons, 1928).

${ }^{190}$ Immanuel Kant, Theodore Greene, and John Silber, Religion within the Limits of Reason Alone (New York: Harper, 1960).

${ }^{191}$ Georg W. Hegel, Lectures on the Philosophy of Religion (London: Routledge \& Paul, 1962).

${ }^{192}$ George Lindbeck, The Nature of Doctrine: Religion and Theology in a Postliberal Age (Philadelphia: Westminster, 1984).
} 
ecological issues in academic Protestantism. ${ }^{193}$ All the while being criticized along the same lines as RCs for their seeming delinquent environmental attitudes, Protestants have rightly begun taking a much more active theological approach towards these issues. Interestingly, it is those who criticize Protestantism for its inability to care for the earth who attempt to deconstruct possibly the most ecologically beautiful creation narrative humanity has seen to date, deeming it no more than "myth." For the majority of Protestants, no other narrative is worthy to be built on than that of the biblical narrative of creation found in the book of Genesis. And theology, especially biblical theology, is where transformation must take place for Protestant ecotheology whose post-Reformation emphasis on the biblical tradition is its main theological foci. Great disdain for Christian theology's perspective towards the earth, and Protestant theology in specific (e.g. Ian McHarg $\left.{ }^{194}\right)$, has been quite successful in caricaturing Protestant theology as "domineering" and "careless." Although elements of this critique are overwhelmingly valid, the environmental movement has largely been ignorant of Protestant work in the environmental field. Fortunately there is evidence showing this is in many ways beginning to shift. ${ }^{195}$ Yet since Protestantism has "no single ecotheology or set of

\footnotetext{
${ }^{193}$ For two seminal texts on these issues, see Max Oelschlaeger's text on late modern ethics Max Oelschlaeger, Postmodern Environmental Ethics (Albany: SUNY Press, 1995). Similarly, for his work on the history of the "idea of wilderness" which offers a late modern view of nature and environment, see Max Oelschlaeger, The Idea of Wilderness: Prehistory to the Age of Ecology (New Haven: Yale University Press, 1991).

${ }^{194}$ Ian McHarg, Design with Nature (Garden City: Natural History Press, 1969). For a critical engagement of McHarg's proposals, see David Engel, "Elements in a Theology of Environment," ZY 5.3 (1970), 216228

${ }^{195}$ Roderick Nash, The Rights of Nature: A History of Environmental Ethics (Madison: University of Wisconsin Press, 1989).
} 
political beliefs" regarding ecotheology, what can we discern as a Protestant green theology $?^{196}$

To begin, an eschatological resurgence has produced a fresh Protestant ecotheology on various levels. In broad strokes, the quest for the historical Jesus of Weiss and Schweitzer reexamined the "imminent" parousia of Jesus, ultimately coloring Protestant's theology of creation as it relates eschatologically to Christ. ${ }^{197}$ That is to say, because Christ did not return as expected during apostolic times, eschatology must have a more nonapocalyptic and present/future dimension. This emphasis of expectant hope as the eschatological lens through which creation is seen is not lost on Moltmann and is often the very basis of his eschatological theology. ${ }^{198}$ Likewise, Paul Santmire's work, done from a Protestant perspective, was initially a response to Lynn White's work of the 1960s, yet it quickly became very important in comprehending early Protestant ecotheological formation. Santmire's Travail of Nature, praised by White himself, gives the historical roots of ecotheology in Western Protestant forms a clear and insightful look. He surmises that Western theology (and in turn Protestantism) has been with its eschatological emphasis, "neither ecologically bankrupt...nor replete with...ecological riches." ${ }^{\prime 199}$ But it is doubtful as to if this is singularly attributable to eschatology. Sallie McFague has similarly been critical of the Protestant tradition for being too connected to

\footnotetext{
${ }^{196}$ Robert Fowler, The Greening of Protestant Thought (Chapel Hill: University of North Carolina Press, 1995), 3.

${ }^{197}$ For an examination of the eschatological nature of the teachings of the quest for the historical Jesus, and the eschatological hope of the early church, see Albert Schweitzer and John Bowden, The Quest of the Historical Jesus (Minneapolis: Fortress, 2001); Johannes Weiss, Earliest Christianity: A History of the Period A.D. 30-150 (Gloucester: Peter Smith, 1970).

198 Jürgen Moltmann, The Coming of God: Christian Eschatology, trans. Margaret Kohl (Minneapolis: Fortress, 1993).

${ }^{199}$ Paul Santmire, The Travail of Nature: The Ambiguous Ecological Promise of Christian Theology (Minneapolis: Fortress, 1985), 8.
} 
medieval dualistic views of the cosmos as mechanism, concluding its focus has been "on the individual and otherworldly salvation...divided what we are now trying to bring back together, and what must be reintegrated if we and other beings are to survive and prosper." ${ }^{200}$ Although it is unclear if McFague understands that such soteriological views on individual and "imminent" views of eschatology could be accommodating for sustaining individuals in social justice in light of the approaching return of Jesus.

Therein lies the strength of Protestant ecotheology — a resurging ecotheology based on a nonapocalyptic eschatology. This is echoed in the work of Dietrich Bonheoffer who wrote, "Only he who loves the earth and God in the same breath can believe in the Kingdom of God." ${ }^{201}$ Bonheoffer's particular perspective, while not written at a time when ecotheology was given attention, reconfigures Christological and soteriological motifs as pointing beyond salvation afterlife to the "here-and-now." This is similar to what Wesley Granberg-Michaelson speaks of as "creation's Pentecost." ${ }^{202}$ This Pentecost of the Spirit in the world should lead to a more respectful living towards it. With the current trend of PC experience in the world as the background, GranbergMichaelson argues that the framework of an Acts 2 Spirit-filled life should include all of creation as well as the church.

\footnotetext{
${ }^{200}$ Sallie McFague, "A Square in the Quilt: One Theologian's Contribution to the Planetary Agenda," in Spirit and Nature, eds. Steven Rockefeller and John Elder (Boston: Beacon Press, 1992), 39-58 (56-57).

${ }^{201}$ Jürgen Moltmann and Douglas Meeks, The Open Church: Invitation to a Messianic Life-Style (London: SCM, 1978), 42.

${ }^{202}$ Wesley Granberg-Michaelson, A Worldly Spirituality: The Call to Take Care of the Earth (San Francisco: Harper \& Row, 1984), 137-151. See also Wesley Granberg-Michaelson, "Covenant and Creation," in Liberating Life, eds. Charles Birch, William Eakin, and Jay McDaniels (Maryknoll: Orbis, 1990), 27-36. On his perspective of the covenantal nature of creation and for an early perspective of his ecotheology see Granberg-Michaelson, Ecology and Life: Accepting Our Environmental Responsibility.
} 
Protestant theology and eschatology have been affected perhaps no more than through the theology of Jürgen Moltmann, who significantly reset the Protestant theological agenda for the twenty-first century, refocusing theology on this eschatological hope centered on Christ's crucifixion and a Spirit's kenosis. For Moltmann, the cross literally becomes "the hope of the earth," the very meeting ground where God encounters a suffering creation. ${ }^{203}$ Moltmann has shown us how socially, ethically, and politically charged theology based on this Christological suffering could help uncover a recapitulated green theology for the twenty-first century. A large part of this is Moltmann's reading of the Bible, his "Hermeneutic of Hope"; having been a crucible not only for the reformation of theology, biblical studies, and hermeneutics, but also for the present discussion regarding ecological issues. ${ }^{204}$ How Christians read the Bible, through a lens of eschatological hope, ultimately changes their praxis in the world. Therefore, Moltmann's reconstituting of an emphasis on hermeneutics as ground for any form of Christian praxis has turned the discussion upside down. Hermeneutical reading shapes living in the world. For an eschatological reading of the Bible, eschatological expectation no longer brings cause for ecological destruction, but care and stewardship ${ }^{205}$ in the light of eschatological hope makes this change possible. This is made possible, again, with an eschatological reading of the biblical text.

\footnotetext{
${ }^{203}$ Moltmann, The Coming of God, 21. As well, for an overview of Bonheoffer's theology of ecology, see Larry Rasmussen, Earth Community, Earth Ethics (Maryknoll: Orbis, 1996).

204 Jürgen Moltmann, Experiences in Theology: Ways and Forms of Christian Theology (Minneapolis: Fortress Press, 2000).

${ }^{205}$ I am aware of the variable issues surrounding terminology of "stewardship," first and foremost its absence from the biblical narrative. Regardless, I find it a helpful word at points because of its widespread usage in Christian ecotheological language.
} 
As mentioned, Moltmann's kenotic theology is seminal to his ecotheology. $\mathrm{He}$ argues ontologically that God experiences the suffering of creation through both the cross and the Spirit that was poured out at Pentecost, which now lives in the enslaved creation. While the Hebrew OT scriptures give seemingly numerous examples of the theodicies of God, the Greek NT scriptures portray a God that did more than just show up, but experienced the pain of the cross willingly. ${ }^{206}$ Finally, Moltmann gives significant attention, where other ecotheologians fail, to the essential nature of God and space. ${ }^{207}$

Robert Fowler, in his The Greening of Protestant Thought, contends that the two key elements shaping Protestant ecotheology are: first, the post-Lynn White responses (such as Paul Santmire), and secondly, an emerging dialogue between Protestant ecotheology and process theology. ${ }^{208}$ Process theology from Whitehead on has transformed much of Protestant ecotheology as typified through the work of John Cobb $\mathrm{Jr} .{ }^{209} \mathrm{Cobb}$ devoted the majority of his scholarly attention to synthesizing the work of Alfred North Whitehead to Christian theology and an ecological agenda, culminating in what he calls "process ecology." ${ }^{, 210} \mathrm{~A}$ vital feature of Cobb's scholarship is a uniquely culminating synthesis of a process framework from a non-Kantian perspective for a

\footnotetext{
${ }^{206}$ For John Hick's work on theodicy, where he gives examination to the idea on the suffering God who suffers with those who suffer, see John Hick, Evil and the God of Love (London: Macmillan, 1966).

${ }^{207}$ Jürgen Moltmann, God in Creation: A New Theology of Creation and the Spirit of God (Minneapolis: Fortress, 1993), esp. chap. 6.

${ }^{208}$ Fowler, The Greening of Protestant Thought, 91-107.

${ }^{209}$ For Whitehead's formative philosophy of nature, see Alfred North Whitehead, The Concept of Nature (Amherst: Prometheus Books, 2004). Whitehead was a theist, although his theology was significantly unlike a Judeo-Christian framework. Traditional process theology has become a synthesis of his work of "becoming" with the ontology of Christian theology tending to emphasize "being."

${ }^{210}$ Cobb's work, based largely on a Whitehead foundation, is very similar to Chardin's cosmogenesis and Omega Point theory proposing that the created order is "becoming" one being ultimately climaxing. Although this is evidenced in all of Cobb's work, for another example, see John Cobb, God and the World (Eugene: Wipf and Stock, 1998).
} 
theological/ecological interplay found in his A Christian Natural Theology ${ }^{211}$ His work has proven to be rather accessible to other non-Christian theological systems due to his often universal and open-ended framework of theology. ${ }^{212} \mathrm{Cobb}$ 's work has been similar in many ways to that of the social and ethical criticisms of Jacques Ellul. Ellul and others have taken issue with modern scientific thought on global issues regarding ecology, which Ellul argues is anything but "merely technological." ${ }^{\text {213 }}$ With Ellul, Cobb critiques the cultural mindset of Western globalism, which he argues, along with the scientific and theological, is a main contribution to the global blame for the crisis at hand. ${ }^{214}$ Cobb's For the Common Good, published alongside economist Herman Daly, provides insight into the culmination of his thought in terms of ecotheological issues as they relate to economic and social theory. ${ }^{215}$ Much of Cobb's work is likewise critical, not only of Western epistemology, but economic theories post-Adam Smith that were built on his Wealth of the Nations. ${ }^{216}$ Cobb's work is often seen as a complete overhaul of the

${ }^{211}$ John Cobb, A Christian Natural Theology: Based on the Thought of Alfred North Whitehead (Philadelphia: Westminster, 1965).

${ }^{212}$ For instance, Cobb's work is clearly seen as universalistic, seen in such phrases as "Christ is the Way that excludes no ways." John Cobb, Christ in a Pluralistic Age (Philadelphia: Westminster, 1975), 22.

${ }^{213}$ John Cobb, Is It Too Late?: A Theology of Ecology (Denton: Environmental Ethics Books, 1995), 16 (italics mine).

${ }^{214}$ For instance Cobb refers to such thinkers as Theodore Roszak and Steward Udall as cultural critics of Western cultural ways of thinking critically on an ecological. See Theodore Roszak, The Making of a Counter Culture: Reflections on the Technocratic Society and Its Youthful Opposition (London: Faber, 1970); Stewart Udall, The Quiet Crisis and the Next Generation (Layton: Gibbs M. Smith Publishers, 1991).

215 John Cobb, Sustaining the Common Good: A Christian Perspective on the Global Economy (Cleveland: Pilgrim 1994).

${ }^{216}$ Ibid. 
classical Christian paradigm and is thus incompatible with a large portion of

Protestantism. $^{217}$

Protestant thinking in ecotheological circles has become focused on the social justice perspective, as we see in Protestant creation theology. Political hegemony, cultural critique, and doubt in "growth models" of Western civilization are a few ways in which "top-down" approaches to thinking have hindered ecotheological discussion. ${ }^{218}$ Much of the Protestant milieu has been affected by the ongoing rippling affects of Ellul's Marxist critique of the technological society. ${ }^{219}$ While being very critical of the Christian “institutional” tradition, Ellul was significant in creating criticisms of predominately Western views of technique and technology, which in the long term have been forces he believed contribute to the ecological destruction in the world. ${ }^{220}$ Such political reconstructions are often centered on an ethical reappraisal. A growing trend of Protestant theology is taking place, arguing theologically that care for animals is a necessary element of theological practice. ${ }^{221}$ In this regard, a number of Protestant theologians such as Andrew Linzey, Carol Adams, Matthew Scully, Jay McDaniel, Stephen Webb, and Laura Hobgood-Oster have attempted to keep creational theology, especially regarding animals and animal rights, as a theological agenda for the twenty-first century. Hobgood-

\footnotetext{
217 Cobb refers to the emerging Christian ecovision as "the New Christianity." One would question the necessity of a "new" Christianity, or simply an updated Christian theology. For an examination of Cobb's language on this "the new Christianity," see Cobb, Is It Too Late?, 31-35.

${ }^{218}$ A term I borrow from K.C. Abraham regarding our model of "economic growth," which since the Western turn towards capitalism has been viewed as boundless and endless. K.C. Abraham, "A Theological Response to the Ecological Crisis," in Ecotheology, ed. David Hallman (Maryknoll: Orbis, 1994), 65-78 (66).

219 Jacques Ellul, Technological Society (New York: Alfred A. Knopf, 1973).

${ }^{220}$ On the agenda of technological advance and its relationship to theology and ecotheology, see Ernst Conradie, "Towards an Agenda for Ecological Theology: An Intercontinental Dialogue," ECO 10.3 (2005), 281-343.

${ }^{221}$ Charles Pinches and Jay McDaniel, Good News for Animals?: Christian Approaches to Animal WellBeing (Maryknoll: Orbis, 1993).
} 
Oster has recently grabbed the attention of historical theology with her study on the role animals have played in the Western Christian tradition. ${ }^{222}$ Linzey, most notably, has gained a widespread audience in his studies on the theology of animals. He suggests in his work that he is returning a gospel to holistic earthy experience that must be for the "head, heart, and hand." ${ }^{223}$ Oppression, we can see, is viewed as a smudge on the face of the created order. The God of the created order desires not simply the individual, but the "whole of injured reality.",224

It is important to note the resurgence of green talk through reimagined soteriology among even smaller sections of the Protestant tradition as in the Anabaptist tradition through Calvin Redekop and Gordon Zerbe. ${ }^{225}$ In 1989 the Anabaptists formed the ETF (Environmental Task Force) to openly discuss a response to the global crisis. ${ }^{226}$ Mennonites and Amish have found these discussions accommodating in forming their own distinctive ecotheology, which has shown itself to be focused primarily on the emphasis of "pacifism towards nature."227 The American Baptist Churches of the USA likewise wrote "Creation and the Covenant of Caring" which attempts to enter mainline

\footnotetext{
${ }^{222}$ Laura Hobgood-Oster, Holy Dogs and Asses: Animals in the Christian Tradition (Urbana: University of Illinois, 2008).

${ }^{223}$ Linzey, Animal Gospel, 1. Linzey and others draw heavily on animal ethics in the line of Mary Midgley and others. For an exemplary work of animal ethics by Midgley, see Mary Midgley, Beast and Man: The Roots of Human Nature (Ithica: Cornell University Press, 1978); Mary Midgley, Animals and Why They Matter (Athens: University of Georgia Press, 1983).

224 Miroslav Volf, Work in the Spirit: Toward a Theology of Work (Eugene: Wipf and Stock, 1991), 104.

${ }^{225}$ For an example of an Anabaptist reimagined soteriological schemata, see Denny Weaver, Keeping Salvation Ethical: Mennonite and Amish Atonement Theology in the 19th Century (Scottdale: Herald Press, 1997).

${ }^{226}$ For an overview of the findings and decisions of this taskforce, see the text of "Stewardship of the Earth, Resolution on Environment and Faith Issues" at http://www.gameo.org/encyclopedia/contents/S7592.html, (accessed August 7, 2008).

227 Calvin Redekop, Creation \& the Environment: An Anabaptist Perspective on a Sustainable World (Baltimore: Johns Hopkins University Press, 2000). See also Linda Burr, Mennonites and the Ecological Crisis (Elkhart: L.M. Burr, 1987).
} 
Baptist traditions into the ecological conversations. As well, the Evangelical Lutheran Church in America and ELCA Environmental Task Force has published a "Basis for our Caring,,"228 somewhat reacting to much pantheistic thought (“Good, but not God") and emphasis on the "fallen humanity" and "hope" for healing. Many other denominations have undertaken efforts to write theological statements regarding the ecological situation. ${ }^{229}$ The mainline traditions often have a challenging time moving together in one direction because it is often viewed as a collection of individuals rather than a body. ${ }^{230}$

American Evangelicalism as a whole is attempting to escape the shadow of Hal Lindsey's The Late Great Planet Earth, which sadly spread the notion that Evangelicals give little to no attention to the care of the earth. ${ }^{231}$ The Evangelical Declaration on the care of creation has been a significant contribution by the Evangelical community to the green issues. ${ }^{232}$ While some elements of the Evangelical camp have struggled to come to terms with the green movement out of fear, among other reasons, a majority of Evangelicals seem to be getting on board to at least converse. The Evangelical Environmental Network, Target Earth, Earth Ministry, and Restoring Eden have all assisted in taking the conversation to the next level within Evangelical communities. While fundamentalist premillenial dispensationalism through such works as Lindsey's have done little to conjure up much of an ecotheological imagination, Evangelical

\footnotetext{
${ }^{228}$ Philip Hefner, Carol Tabler, and Melanie Martin-Dent, "Caring for Creation: Vision, Hope, and Justice: Proposed Social Statement, Division for Church in Society," DG 32.3 (1993), 224-228.

${ }^{229}$ To view such statements, visit the websites of the following: Episcopalian (www.ecusa.org), Lutheran (www.elca.org), United Methodist (www.umc.org), Presbyterian USA (www.pcusa.org), and the Southern Baptist Convention (www.sbc.org). Thanks to Laura Ruth Yordy for this helpful list in her Laura Ruth Yordy, Green Witness: Ecology, Ethics, and the Kingdom of God (Eugene: Cascade Books, 2008), 8.

${ }^{230}$ On this view within the mainline traditions, see ibid., 11.

${ }^{231}$ Hal Lindsey, The Late Great Planet Earth (Grand Rapids: Zondervan, 1970).

232 Robert Berry, The Care of Creation: Focusing Concern and Action (Leicester: IVP, 2000).
} 
theology and scholarship has made strident efforts to become ecological conversant with its fundamentalist roots and academic pursuits. Evangelicals have taken a much more prominent practical role in accommodating "green” Evangelical congregations.

On a more public scene, prominent Evangelical scholars have worked tirelessly to see the political landscape change. For instance, Reformed theologian/environmental scientist Calvin Dewitt at the University of Wisconsin and the Evangelical Environmental Network took action to support the political work of the Endangered Species Act (ESA) in $1995-96 .{ }^{233}$ Similar to the broader Evangelical ecotheology context, Dewitt argues for a theological model of ecology based Christologically. ${ }^{234}$ He asks the important question: “Is Christ the Lord of Creation?"235 Dewitt's work, though distinctively Evangelical in scope, attempts to engage environmental issues through the lens of Reformed theologians, most notably Abraham Kuyper and John Calvin. ${ }^{236}$ Steven BoumaPrediger's work has similarly contributed as a thoughtful expression in the Evangelical ecotheology discussion. Drawing on Joseph Sittler and his seminal Lutheran ecotheology, Bouma-Prediger provides the Evangelical audience an accommodating and practical framework to develop its own unique bourgeoning discussion. ${ }^{237}$

\footnotetext{
233 See www.creationcare.org, (accessed August 8, 2008).

${ }^{234}$ For an overview of a Christological ecology model based on the NT, see Calvin DeWitt, The Environment and the Christian: What Does the New Testament Say About the Environment? (Grand Rapids: Baker, 1991); Wesley Granberg-Michaelson, Tending the Garden: Essays on the Gospel and the Earth (Grand Rapids: Eerdmans, 1987).

235 DeWitt et. al., Caring for Creation.

${ }^{236}$ For an introduction to the reformed theology behind DeWitt's thought and Calvin's seminal idea of "custody," see ibid.

${ }^{237}$ See also his Steven Bouma-Prediger, The Greening of Theology: The Ecological Models of Rosemary Radford Ruether, Joseph Sittler, and Jürgen Moltmann (Atlanta: Scholars Press, 1995); Bouma-Prediger, For the Beauty of the Earth; Steven Bouma-Prediger and Virginia Vroblesky, Assessing the Ark: A Christian Perspective on Non-Human Creatures and the Endangered Species Act, Crossroads Monograph
} 


\subsection{Ecofeminist Ecotheology $y^{238}$}

Finally, following our examination of RC, Orthodox, and Protestant ecotheology, we turn our attention to ecofeminist ecotheology. Ecofeminism, a rather new set of cultural and academic developments, rightly deserves a section all on its own in our survey. Although ecofeminism is not considered a singular movement, Val Plumwood has commented it has become somewhat of an invisible college. ${ }^{239}$ Within, there has developed such strength behind ecofeminist movements that it is quickly reshaping and refining the conversation, which includes the expressions found in ecofeminist theory and theology alike. Ecofeminist thought brings a theological diversity due to its nature, with ecofeminist Protestants, RCs, Orthodox, and even Pentecostals. In a way, it offers an almost ecumenical discussion platform that bridges denominational and ecclesial lines. This gives rise to the need to give it a voice of its own in our discussion in green theology. Historically, the ecofeminist movement(s) began in the 1960s as an academic enterprise with the early expressions of Susan Griffin, Mary Daly, Carol Adams, Carolyn Merchant, among others. While it is nearly impossible to pin down the beginning of the movement, many point to Susan Griffin's seminal work Women and Nature: the Roaring Inside Her (1978), Rosemary Ruether's New Woman, New Earth (1975), and Elizabeth

Series on Faith and Public Policy, vol. 1 (Wynnewood: Crossroads, 1997). The latter text discusses many of the political elements to the conversation between Evangelicals and the ecological movement.

${ }^{238}$ The term "ecofeminist" was originally discussed in Le Feminismeu la Mort by French Françoise d'Eaubonne in 1974 regarding the relationship between ecology and feminism.

${ }^{239}$ Valerie Plumwood calls the ecofeminist movement an "invisible college" in the introduction to her text, Val Plumwood, Feminism and the Mastery of Nature (New York: Routledge, 1993). 
Gray's Green Paradise Lost (1979) as major stepping-stones in the establishment of this movement. $^{240}$

These diverse sets of communities find their philosophical grounding in the idea that earth (ecology from oikos - the study of the "household") and the female person have both been "put in their place" by global andocentric (male-centeredness) thought and practice culminating in cultural gender infringement as long as humanity has existed. It was the French Francoise d'Eaubonne who defined this movement as a calling "upon women to lead an ecological revolution to save the planet" with the dual purpose of redeeming the earth and the female spirit. ${ }^{241}$ With a strong social zeal, it took root on a global scale. In large part it has sought to remind history of a narrative that was not always so male-centered and has not always sought the "death of nature."242 It is ecofeminist theory and history that has been quick to remind us that the earliest humans viewed nature as a feminine being where even Paleolithic hunter-gatherers no doubt saw the natural world as a female entity.

From an ecofeminist theological perspective, creation is envisioned as cooppressed with the female personhood. Sociological, cultural, and political change has been a goal of ecofeminist thought for half a century and has clearly affected theological discussion in ecclesial settings as Christians and theologians alike discuss how God's

\footnotetext{
240 Susan Griffin, Women and Nature: The Roaring Inside Her (New York: Harper \& Row, 1978); Rosemary Ruether, New Woman, New Earth: Sexist Ideologies and Human Liberation (New York: Seabury Press, 1975); Elizabeth Gray, Green Paradise Lost (Wellesley: Roundtable, 1981).

241 Quoted in Heather Eaton, Introducing Ecofeminist Theologies, Introductions in Feminist Theology, vol. 12 (New York: T\&T Clark International, 2005), 3.

242 A term used by Carolyn Merchant referring to seventeenth-century mechanization of women and nature. Chapter one offers an overview of the idea of nature as mother. Carolyn Merchant, Radical Ecology: The Search for a Livable World (New York: Routledge, 2005).
} 
image is apparent in both genders. Ecofeminist Mary Daly says that as a system, ecofeminist thought "involves a thoroughgoing analysis of the dualisms that structure patriarchal culture. ${ }^{, 243}$ For Daly, patriarchal thought is by and large the basis of andocentrism bearing fruit in cultural phenomenal that seek to marginalize women and earth. In a similar tone, Eleanor Rae has eloquently argued that ecofeminism is a sharp contrast to two aspects of andocentric Western Christianity: instrumentality, the view that women and earth are only good for what they do, and dualism, that God is good and the cosmos is bad. ${ }^{244}$ This dualism is what led Elizabeth Gray to call the earth the "green nigger," a being human oppressors have treated the same way we treated the black slaves. $^{245}$

It may well be that ecofeminist models are a widespread reactions to atomistic models presented by Western dualism. ${ }^{246}$ While these early ecofeminist voices grew louder, academic theology began to become conversant in the issues raised by these thinkers. Such ecofeminist thinkers as Sallie McFague, Carol Adams, Kathryn Tanner, Rosemary Ruether, and Elizabeth Johnson have become prominent in these discussions. There are a tremendous amount of helpful resources to navigate this field. From an interreligious perspective, Carol Adams' work has played a significant role culminating in her Ecofeminism and the Sacred which brings together many ecofeminist expressions

\footnotetext{
243 Lois Daly, "Ecofeminism, Reverence for Life, and Feminist Theological Ethics," in Liberating Life, eds. Charles Birch, William Eakin, and Jay McDaniel (Maryknoll: Orbis, 1990), 88-108 (94).

244 Eleanor Rae, Women, the Earth, the Divine (Maryknoll: Orbis, 1994), 30-35.

245 Elizabeth Gray, Why the Green Nigger?: Re-Mything Genesis (Wellesley: Roundtable Press, 1979). Similar linguistic terminologies have become rather popular in ecological writings. For instance, it was Sean McDonagh who posed the image of earth as having AIDS. Sean McDonagh, The Greening of the Church, 23.

246 This is the argument of McFague's in, A New Climate for Theology, esp. chap. 3. For other helpful engagements of the topic of dualism, see Donald Gelpi, The Gracing of Human Experience: Rethinking the Relationship between Nature and Grace (Collegeville: Liturgical Press, 2001), 28.
} 
from Hindu, Buddhist, and Jewish perspectives, which are globally shaping this conversation. ${ }^{247}$ Adams' recent work has caught the attention of many arguing from an ecofeminist perspective that andocentric thought can be seen through the use of meat in cultures abroad and in particular the West. ${ }^{248}$

As the apostle Paul mentions, the Spirit "groans eagerly" (Rom. 8:23), suffering in the expectation of redemption. Thus God experiences suffering of the creation in what Ruth Page calls "the thick of all nonhuman suffering." ${ }^{" 249}$ The argument could be made therefore that the redemption of the earth is only as possible inasmuch as the redemption of women is possible. It is as the image of the divine is respected, honored, and celebrated in women, that the same can take place ecologically. This is how ecofeminist emphasis on holism is central. Since 1971, Rosemary Ruether has played an integral role in ecotheological discussion, bringing together the worlds of Gaia theory and ecofeminist thought to form holistic views of creation and gender roles. ${ }^{250}$ In a synthesis of cosmological models depending on Gaia theory or interconnectivity of life and the central role women play in humanity, Ruether leaves little room for a theology that advocates beating the wife with one hand and recycling with the other. This "suffering" motif, as well as ecofeminist theology as a whole, draws on early church voices advocating historically that the church has not always been so andocentric. Thus, the early fathers did not separate Christology from natural issues, often speaking of the "pantocrator" and

\footnotetext{
${ }^{247}$ Carol Adams, Ecofeminism and the Sacred (New York: Continuum, 2007).

${ }^{248}$ Carol Adams, The Sexual Politics of Meat: A Feminist-Vegetarian Critical Theory (New York: Continuum, 1990).

${ }^{249}$ Ruth Page, God and the Web of Creation (London: SCM, 1996), xiii.

${ }^{250}$ Ruether, Sexism and God-talk.
} 
"cosmocrator." ${ }^{, 251}$ We are reminded as well that Celtic spirituality is creationally-oriented, significantly more respectful of women and earth that its Western counterparts.

Ecofeminism as well argues for a return to the dynamic creative elements of God. As the feminine spirit is a creative one, so is the Spirit of God that continues to create at all moments (creatio continua). The creative play of God, or what Amos Wilder called the theopoetic, is a necessary element to right relationship with creation. ${ }^{252}$

Individualization, overworked families, and modern compartmentalization have all lead to the death of the creative spirit, which returns the health to our relationship with creation. This relational stream found in ecofeminist thought is echoed in Dawn Nothwehr's fascinating text and contends that this mutuality must be the central motif of an ethic for the environment. ${ }^{253} \mathrm{~A}$ large part of the destruction of this relationship is due to humanity's separation from creation, resulting as the explosive growth of cities, modernization, and the industrial renaissance. It was Weber's observation that Protestantism gave capitalism the steam it needed to take off. And in particular, such capitalistic societies as the USA and Europe move to city life, combined with a Protestant Work Ethic, many have used Christianity as a way to escape the creative order. $^{254}$

\footnotetext{
251 This distinction is illuminated in McDonagh, The Greening of the Church, 165.

${ }^{252}$ Amos Wilder, Theopoetic (Philadelphia: Fortress, 1976). For an example, the work of Sara Maitland seeks to restore the creative elements to Christian worship and experience. Sara Maitland, A Big-Enough God: A Feminist's Search for a Joyful Theology (New York: Riverhead Books, 1996).

${ }^{253}$ Dawn Nothwehr, Mutuality: A Formal Norm for Christian Social Ethics (San Francisco: Catholic Scholars Press, 1998).

${ }^{254}$ Max Weber, The Protestant Work Ethic and the Spirit of Capitalism (New York: Penguin, 2002).
} 
Likewise, there have been many investigations into Third World feminist theologies and how non-Western worlds treat women. ${ }^{255}$ Rosemary Ruether observes this interesting theme in her idea of a modern "salvation from nature," which examines the human attempt to surround themselves with technology so as not to have to experience the realness of their bodies and the world around them. ${ }^{256}$ The fear of the human bodies must be overcome because fear is a driving force, in ecofeminist thought, for the destruction of women and earth - a fear that has largely remained in the church and ecclesial systems. A large section of Sexism and God-talk gives a good historical criticism of early church dominance of women and the fear that has played into that dominance. ${ }^{257}$

Finally, Sallie McFague has picked up on the practical side to these issues. McFague argues from a functional cosmological perspective that theology must lead to a "love for the neighbor," which she recategorizes as nature, not our human beings alone: "Christian love to neighbor should be extended to nature." ${ }^{, 258}$ She also argues for a return to a "mystery-centered" view of creation, constructing a model of God as a body. ${ }^{259}$ This emphasis has taken the theological pressure off what some criticize is the most dangerous element of Christian theology, the monarchical model of God as King, which is predominant in Greek and Hebrew scriptures and continued throughout Protestant

\footnotetext{
${ }^{255}$ Katie Cannon et. al., Inheriting Our Mothers' Gardens: Feminist Theology in Third World Perspective (Philadelphia: Westminster, 1988).

${ }^{256}$ Ruether, Sexism and God-Talk, 79.

${ }^{257}$ Ibid.

${ }^{258}$ Sallie McFague, Super, Natural Christians: How We Should Love Nature (Minneapolis: Fortress, 1997).

${ }^{259}$ Sallie McFague, The Body of God: An Ecological Theology (Minneapolis: Fortress, 1993), 6.
} 
conceptions of God's sovereignty. ${ }^{260}$ We will discuss McFague's work more adequately in chapter 5 .

\subsection{Summary}

Throughout this chapter we have examined four major areas of Christian ecotheology. First, we looked at RC and its emphasis on creation theology, the dignitas terrea, and liberation theology of the earth. Then the Orthodox showed us their view of the iconic and sacramental nature of creation. Protestant and Evangelical theology emphasized eschatological hope, social zeal, and biblical theology. And finally, ecofeminist movements showed us the connection between the oppression of earth and the female personhood, ultimately highlighting the need for their coredemption. This chapter serves primarily as an overview chapter, examining these trends so as to set a setting for PC ecotheology in the following chapter. Now we will continue forward with an examination of one of the larger remaining Christian traditions - the PC traditions.

\footnotetext{
${ }^{260}$ For an excellent text engaging the monarchical views of God through the Western historical model, see Ian Barbour, Myths, Models, and Paradigms: A Comparative Study in Science and Religion (New York: Harper \& Row, 1974), 156.
} 


\section{Chapter 3}

\section{ECOGLOSSOLALIA-THE TONGUES OF A TWENTY-FIRST CENTURY PENTECOSTAL ECOTHEOLOGY}

Now that we have overviewed the wider Christian ecotheological landscape, we will now examine a typology of the PC contributions to ecotheology beginning with Larry Christenson's construction of a Charismatic social justice in $1974 .{ }^{261}$ This will continue our journey towards developing a Pentecostal ecopneumatology constructed in dialogue with a larger Christian ecotheology (chapter 2), our three ecopneumatologies (chapter 4), and Pentecostal pneumatology (chapter 5). In this chapter, we will examine and critique the salient late twentieth and early twenty-first century PC writings which will serve as the framework for a Pentecostal ecopneumatology. Thus, three trajectories will be identified, surveyed, and examined. First, we will engage the theological writings within PC traditions that have opened the door for PC social justice. Secondly, we will examine the formative PC voices that have shaped Spirit/creation theologies. And thirdly, we will isolate the distinctive Pentecostal ecotheologies that have approached ecotheology outside the scope of pneumatology. This chapter's final section will articulate a summary and critique of each trajectory suggesting its overall value to a twenty-first century Pentecostal ecopneumatology.

261 Again, for sake of space, we are limiting ourselves to the last thirty-five years of PC scholarship. 


\subsection{Introduction}

Similar to earlier attempts at tracing the historical/theological trajectories that have shaped global Pentecostalism such as those of Walter J. Hollenweger, this will be an exercise at identifying some "roots." Hollenweger, in examining the complexity of Pentecostalism, identified five Pentecostal "roots": black/oral, evangelical, Catholic (Methodist), critical, and ecumenical. ${ }^{262}$ Our journey will similarly continue along the same lines articulating what influences (or "roots") exist under the surface for the continued development of a contemporary PC ecotheology. As we will see, since the late1970s, a number of ecotheological works, themes, and motifs have developed within PC scholarship.

But where do we begin? As with any journey, there is always a starting point. That is to say today's answers often emerge from yesterday's questions; or what Walter Brueggemann has hailed the "governing questions of the discipline." ${ }^{263}$ As we have already observed in chapter 2, RC, Orthodox, Protestant, and Ecofeminist ecotheologies emerged in the context of their own sets of questions and assumptions. A Pentecostal ecotheology will likewise be centered on its own set of governing questions. Truly, the

\footnotetext{
${ }^{262}$ For a synopsis of Hollenweger's analysis of this five-fold "root" system, see his Walter Hollenweger, Pentecostalism: Origins and Developments Worldwide (Peabody: Hendrickson, 1997). For a compelling examinations of the landscape of Hollenweger's thought and theology with a helpful biography, see Lynne Price, Theology out of Place: A Theological Biography of Walter J. Hollenweger, JPTSup, vol. 23 (London: Sheffield Academic Press, 2002). Allan Anderson forwards the thesis that these "roots" are the basis for ecumenical dialogue between Pentecostals and non-Pentecostals. Anderson, An Introduction to Pentecostalism, 251.

${ }^{263}$ Brueggemann, Theology of the Old Testament, 1.
} 
Pentecostal "twist" adds new questions to the ecological discussion. ${ }^{264}$ As part of its continual development, emerging Pentecostal ecotheology is part of a broader Pentecostal discovery of new worlds and lands. Luckily, new lands are nothing new for Pentecostals. For more now than ever, at least demographically, Pentecostals have spanned the globe most notably in the South and the East. ${ }^{265}$ As well, this expanding influence is increasingly the case on a cultural level. Evidence seems to suggest that Pentecostals have emerged from a countercultural infancy into a more mainstream adolescence preparing for adulthood: influencing, participating in, and integrating themselves into every avenue of the global marketplace and culture. ${ }^{266}$ More and more this diaspora of Spirit-filled Pentecostal wanderers have integrated their lives into the surrounding culture throughout denominations, nations, and foreign lands as a sort of invisible college or "cumulative tradition."267 While their impact in Western and European cultures has become somewhat of a minority report, their impact in nearly all other corners of the globe has grown, influencing, and being influenced by every imaginable avenue of

\footnotetext{
${ }^{264}$ I of course borrow the language of the Pentecostal "twist" from Kenneth J. Archer. Kenneth Archer, "Pentecostal Story: The Hermeneutical Filter for the Making of Meaning," PNEUMA 26.1 (2004), 36-59.

${ }^{265}$ For statistical information on Pentecostal movements, see "Statistics Global" in S.M. Burgess and M. van der Maas, eds., NIDPCM, 283-303; Philip Jenkins, The New Faces of Christianity: Believing the Bible in the Global South (Oxford: Oxford University Press, 2006). For the most recent research of PC demographic growth, see http://pewforum.org/, (accessed June 14, 2009). Andrew Wall has examined the global Christian shift to the South and its effect on the study of church history, "Christianity in the NonWestern World: A Study in the Serial Nature of Christian Expansion," SWC 1.1 (1995), 1-25.

${ }^{266} \mathrm{I}$ borrow the language of adolescence and adulthood regarding Pentecostalism from Cheryl Bridges Johns, "The Adolescence of Pentecostalism: In Search for a Legitimate Sectarian Identity," in PNEUMA 17.1 (1995), 3-17. For a specific contextual case study from the Australian continent, see Barry Chant, "The Promise of the Charismatic Movement," in The Shape of Belief: Christianity in Australia Today, eds. Dorothy Harris, Douglas Hynd, and David Millikan (Homebush West: Lancer, 1982), 109-122. Walls calls this overall move of Christianity including the Pentecostal shifts to the South, "the southward swing of the Christian center of gravity." Andrew Walls, "Of Ivory Towers and Ashrams: Some Reflections on Theological Scholarship in Africa," JACT 3.1 (2000), 1-4 (1).

${ }^{267}$ I borrow "cumulative tradition" here from Wilfred Cantwell Smith who critiqued the notion of one monolithic "religious system" as an adequate category of belief. Wilfred Cantwell Smith, The Meaning and End of Religion (Minneapolis: Fortress, 1991).
} 
culture. Some have suggested that North American Pentecostals have become less "against culture" (echoing Niebuhr's five-fold framework) than at any other earlier time in its short history. ${ }^{268}$ This mobility, coupled by a tendency to spread easily from culture to culture, has afforded it flourishing attention. It truly has become, in the words of Harvey Cox, "a religion made to travel." ${ }^{269}$ And so this expanding Pentecostalism, in its recent travels, has gingerly begun to traverse uncharted territory such as the world of ecotheology. It is, therefore, a truth that no matter how far and easily Pentecostals have traveled the globe, new lands will remain exactly what they are: lands. And new lands will always demand renewed theology. ${ }^{270}$

Two looming methodological questions remain before proceeding. Primarily, why will we draw from non-Pentecostal sources such as the Charismatic and neo-Charismatic traditions to inform a developing Pentecostal ecotheology? I suggest three reasons for this. First, Pentecostals and Charismatics share what Amos Yong calls the "pneumatological imagination,"271 or what Mark J. Cartledge calls "the Charismatic tradition. ${ }^{272}$ For both Yong and Cartledge, Pentecostals and Charismatics share a unique perspective on the Holy Spirit and its role in the Christian story along with a particular view of experience within the Christian experience. While historically many

\footnotetext{
${ }^{268}$ Don Battley argues this from the perspective that Pentecostalism was inherently against culture. See Don Battley, "Charismatic Renewal: A View from Inside," ER 38.1 (1986), 48-56 (55). For the classic Niebuhrian construct, see Richard Niebuhr, Christ and Culture (New York: Harper, 2001).

${ }^{269}$ Follow this isolated theme extrapolated in such works as Cox, Fire from Heaven; Murray Dempster, Byron Klaus, and Douglas Petersen, eds., The Globalization of Pentecostalism: A Religion Made to Travel (Oxford: Regnum Books, 1999).

${ }^{270}$ I would suggest this is the overall point of Hollenweger's move towards "intercultural" theology that sought to situate theology within its larger cultural, religious, and geographical context.

${ }^{271}$ A theme throughout Amos Yong, The Spirit Poured out on All Flesh: Pentecostalism and the Possibility of Global Theology (Grand Rapids: Baker Academic, 2005).

${ }^{272}$ Cartledge, Encountering the Spirit.
} 
Charismatics share little to no denominational ties with classic Pentecostal movements, their genetic historic/theological makeup of which we are speaking comes largely from the Trinitarian pneumatology of historic Pentecostalism. ${ }^{273}$ This has led them both to sustain a deep reverence for the Spirit's role in the life of the believer, her sanctification and gifting, and the overall centrality of Spirit-filled life in ordo salutis. It is this "pneumatological imagination" that will be utilized in our dialogue here. Because of this shared theology, Pentecostals will have a wealth of resources to draw from in the Charismatic and neo-Charismatic movements.

Secondly, the Pentecostal ecotheological sources we will engage significantly lack both in breadth and depth, aside from the few expressions available to date. By and large, the Pentecostal academy, churches, and publications have been, intentionally or not, ecotheologically quiet. To illustrate this quietness, it is arresting to note that the first substantive contribution by a Pentecostal to the ecological conversation was not composed until Jean-Jacque Suurmond's article in $1988 .{ }^{274}$ Since then, to their credit, many more Pentecostal voices have contributed valiant efforts in this regard. It is important to note, therefore, that they have been quiet. These voices have not been silent. Thus, for our purposes, other non-Pentecostal conversation partners will serve as an accommodating assistant in drawing out a stronger Pentecostal expression. In this way, I

\footnotetext{
${ }^{273}$ For instance, see the history the Charismatic renewal and the Charismatic RC movement in the United States. Charles Hummel, Fire in the Fireplace: Contemporary Charismatic Renewal (Downer's Grove: IVP, 1978).

${ }^{274}$ Jean-Jacques Suurmond, "Christ King: A Charismatic Appeal for an Ecological Lifestyle," PNEUMA 10.1 (1988), 26-35. Suurmond's involvement with the Pentecostal movement began in the 1970s as he began doing ministry to the homeless and destitute in a Pentecostal church in the Netherlands. In 1979, Suurmond became a Pentecostal pastor at North Hollywood Assembly of God and became involved with the interdenominational charismatic movement in California and later in the Netherlands. Since 1993, he had been ordained in the Dutch Reformed charismatic tradition.
} 
suggest dialogue with Charismatics will inevitably uncover a promising cadre of rich dialogical sources serving magnificently for a renewed theology of creation. And thirdly, Charismatics offer Pentecostals what I would consider a safe conversation partner. ${ }^{275}$ Pentecostals, partly to their credit, can at times be hesitant to engage "outside the Pentecostal box," for one reason or another. Yet many Charismatics have ecotheology engaged more robustly, especially amongst the Charismatic mainlines, and will offer a safe partner for enriching discussion.

We turn to a second methodological question. Where will Pentecostal ecotheology fit within Pentecostal theology, especially while bereft of a clearly established systematic theology as a theological framework $?^{276}$ For surely such an ecotheology would be enriched by a systematic theology. Simply put, the Pentecostals remain one of the last major Christian traditions to contribute a distinct voice to the ecotheological discussion. ${ }^{277}$ It is unconvincing that this quietness arises out of a lack of systematic theology. Nonetheless, systematic theology may be a helpful in assisting the ecotheological development. Yet, historically, American Pentecostalism and systematic

\footnotetext{
${ }^{275}$ I am reminded here of John Westerhoff"s idea of a "testing community" as a learning context for testing and trying new ideas pedagogically. In this sense, Charismatics offer Pentecostals an ecological "testing community" among safe conversation partners. See John Westerhoff, Will Our Children Have Faith? (Minneapolis: Seabury, 1976), 68.

276 The following represent initial attempts at systematic Pentecostal theologies. French Arrington, Christian Doctrine: A Pentecostal Perspective (Cleveland: Pathway Publishers, 1992); John Higgons, Michael Dusing, and Frank Tallman, An Introduction to Theology: A Classical Pentecostal Perspective (Dubuque: Kendall/Hunt Publishing Co., 1994); Stanley Horton, Systematic Theology: A Pentecostal Perspective (Springfield: Logion Press, 1994); William Menzies and Stanley Horton, Bible Doctrines: A Pentecostal Perspective (Springfield: Logion Press, 1993); Raymond Pruitt, Fundamentals of the Faith (Cleveland: White Wing Publishing House, 1995).

277 This is generally the case as well in ecumenical dialogue. For instance, of the 4,500 participants at the $8^{\text {th }}$ council of the WCC at Canberra, there were no more than eight representatives from PC traditions. Hollenweger, Pentecostalism, 382.
} 
theology in particular have not been best of friends. ${ }^{278}$ Some, such as Kärkkäinen and Yong, have suggested that the strongest resemblance of systematic theology in Pentecostalism is more or less a "borrowed" one from Evangelicalism/Fundamentalism and does not entirely represent a distinctively Pentecostal work. ${ }^{279}$ Some have even suggested that Pentecostalism has succumbed to the "evangelical franchise," in the words of R. Hollis Gause. ${ }^{280}$ Lyle Dabney jokingly compared Pentecostals using Evangelical categories like that of David putting on Saul's armor. ${ }^{281}$ Historically, one could make the case that early-twentieth century Spirit-movements in Wales, Topeka, Los Angeles, and elsewhere were inherently reactionary to overly systematized, dogmatic, and rationalistic expressions of the Christian tradition. We observe as well that since its republication in 2002, the groundbreaking NIDPCM lacks a full-fledged article on God. ${ }^{282}$ This of course does not imply that theological inquiry in the PC strain remains unproductive, but rather to point out an apparent lacking of systematic theology within the mainstream of

\footnotetext{
${ }^{278}$ Kärkkäinen forcefully advances the thesis that Pentecostalism is a "grassroots spiritual movement over a theological construction." Veli-Matti Kärkkäinen, Introduction to Ecclesiology: Ecumenical, Historical \& Global Perspectives (Downer's Grove: IVP, 2002), 90. In a similar vein, Margaret Poloma makes the case that early Pentecostals tended to, despite their experience-centered religion, run from creating systematic theology based on such experience. See Margaret Poloma, The Assemblies of God at the Crossroads: Charisma and Institutional Dilemnas (Knoxville: University of Tennessee Press, 1989), 52. As well, some would make the case there does exist a Pentecostal systematic theology, such as Duffield and Van Cleave's denominational systematic theology. Guy Duffield and Nathaniel Van Cleave, Foundations of Pentecostal Theology (Los Angeles: L.I.F.E. Bible College, 1983). There have, no doubt, been seasons of time where Pentecostals have organized and reorganized theology in response to earlier generational experience. For instance, on the "Pentecostal Scholasticism" of the Assemblies of God in 1930-1955, see David Jacobsen, "Knowing the Doctrine of Pentecostals: The Scholastic Theology of the Assemblies of God: 1930-1955," in Pentecostal Currents in American Protestantism, eds. Edith Blumhofer, Russell Spittler, and Grant Wacker (Urbana: Univerisity of Illinois Press, 1999), 90-107.

${ }^{279}$ On this "borrowed" systematic theology from a fundamentalist/evangelical framework, see Kärkkäinen and Yong, eds., Toward a Pneumatological Theology, xiv.; For more on this see Gary McGee, "“More Than Evangelical': The Challenge of the Evolving Theological Identity of the Assemblies of God," PNEUMA 25.2 (2003), 289-300.

${ }^{280}$ R. Hollis Gause, “A Pentecostal Response to Pinnock’s Proposal,” JPT 14.2 (2006), 183-188 (187).

${ }^{281}$ Lyle Dabney, "Saul's Armor: The Problem and the Promise of Pentecostal Theology Today," PNEUMA 23.1 (2001), 115-117.

${ }^{282}$ S.M. Burgess and M. van der Maas, eds., NIDPCM. Nor is there a section on ecotheology, green theology, or ecological issues. There is a helpful article on social justice that should be carefully engaged.
} 
Pentecostal academic theology. This criticism of both a lack of a truly Pentecostal systematic theology or ecotheology have been growing ones on many levels, yet clear signs show that some are in development. ${ }^{283}$

It would seem that these, developing a systematic theology and an ecotheology, are both Pentecostal growing pains as it matures and grows into the twenty-first century. Now, alongside voicing a more fully developed systematic theology, Pentecostals are being forced to step up to the ecotheology microphone. ${ }^{284}$ As we observed in chapter 2, to their credit, ecotheology in the more long-standing Christian traditions benefit themselves plentifully by being enriched by a more long-standing, historically rooted ecotheology within their traditions, at times flowing from both a rich systematic theology ( $\mathrm{RC}$ and Protestant) and a deep mystical theology (Orthodox and Ecofeminist). ${ }^{285}$ Similarly, it would seem, the broader ecumenical community would desire and benefit from hearing from the fastest growing expression of the Christian faith, the PCs. Again, to illustrate this need, not a single ecotheology offering inside the PC tradition has substantively changed the broader conversation and been engaged by the greater ecumenical

\footnotetext{
${ }^{283}$ For instance, this is evidenced in Keith Warrington's theological endeavor engaging many important elements of a Pentecostal theology. It includes a small, yet helpful engagement of ecological issues for Pentecostals in his section on "Spirituality and Ethics." Keith Warrington, Pentecostal Theology: A Theology of Encounter (New York: T\&T Clark, 2008). For the monumental charismatic systematic theology by one believed to be the father of renewal theology, see J. Rodman Williams, Renewal Theology: Systematic Theology from a Charismatic Perspective (Grand Rapids: Zondervan, 1996).

${ }^{284}$ Likewise, by comparison, note the RC resurgence in the area of pneumatology in postconciliar Catholic theological imagination. Ecotheology has pervaded all elements of culture, academics, politics, and business, what integral philosopher Ken Wilber speaks of as the "green meme." So-called "green talk" has pervaded academic and scholarly circles, being informative even of how to develop academic models and pedagogical philosophy. Ken Wilber, A Theory of Everything: An Integral Vision for Business, Politics, Science, and Spirituality (Boston: Shambhala, 2001), 37.

${ }^{285}$ For instance, Chardin's cosmology relies heavily on RC systematic theology. See Teilhard de Chardin, The Phenomenon of Man; Teilhard de Chardin, Man's Place in Nature. This is as well the case for many Protestants who often rely heavily on the works of John Calvin, Martin Luther, and Abraham Kuyper. The Orthodox have a much less developed ecotheology than the previous two but do have a long-standing tradition of mystical theology that in the long run will benefit their ecological imagination.
} 
community. Very much so, ecotheology, not exactly a PC mother tongue as in other Christian expressions, remains a theological discourse teeming with possibility as it grows beyond a form of private ecological glossolalia. ${ }^{286}$ This present chapter hopes to be an interpretation of such ecological tongues that have quietly been spoken. But at the same time, Pentecostals approach ecotheology with freshness due to their youth and lack of historical academic tradition, especially within the topic of ecotheology.

We therefore begin with the words of Isaac Newton, "If I have seen further, it is because I have stood on the shoulders of giants." The following will be an examination of the shoulders of those creating and dialoguing within the ecological conversation amongst PCs. It will feel to many Pentecostals like learning a new language, what Jeffrey Gros and John Rempel have called an "alien idiom."287 And so we are here going to borrow as many PC ecotheological idioms as possible. And clearly, what is not needed is the novelty for the sake of novelty. Too much paper has been wasted attempting to save trees. Sadly, what often wins the day is what Wendell Berry calls "the cult of originality." 288 But originality is necessary when truth has yet to be discovered. Having said this, fresh air and not new truth is what is needed. The "fresh flowing air of the

\footnotetext{
${ }^{286}$ While Pentecostals may speak in ecological tongues, I would contend the RC tradition, as explored in chapter 2, has a deeply embedded, to borrow a phrase from McFague, "ecological literacy," which Pentecostals are just now beginning to engage. McFague, A New Climate for Theology, 48-50.

${ }^{287}$ Jeffrey Gros and John Rempel, The Fragmentation of the Church and Its Unity in Peacemaking (Grand Rapids: Eerdmans, 2001), 7. It should be noted that ecclesiology as an academic discipline only began to take shape late in the fifteenth century. In this sense, different parts of the universal church need to be open to new areas of learning in each season. Kärkkäinen, Introduction to Ecclesiology, 10. I am reminded of Moltmann's call that this particular area of understanding, nature that is, has become foreign. "Nature and our bodies have both become alien to us." Jürgen Moltmann, The Future of Creation: Collected Essays (Philadelphia: Fortress, 1979), 98.

${ }^{288}$ Berry, Life Is a Miracle, 70.
} 
Spirit," in the words of Karl Barth, will come where "stagnant air automatically prevents it being and doing what it can, may, and must be and do." 289

\subsection{The Tongues of Twenty-First Century Pentecostal Ecotheology}

\subsubsection{Charismatic Social Justice}

Our first trajectory touches on the PC theologies of social justice that have assisted in shaping a larger Pentecostal ecotheology. We will highlight here four major strands that have contributed to a strengthened PC social theology: Charismatic social theology, liberation theologies, eschatological social justice, and African creation spiritualities. This historical/theological tracing commences with Larry Christenson's novel theological construct for a charismatic social justice in his A Charismatic Approach to Social Action (1974). ${ }^{290}$ Coming off the heels of perhaps one of the more important pneumatological works of the century—John Taylor's The Go-Between God (1972)—Christenson's social theology largely served as an extension of Taylor's theology to the Charismatic community. ${ }^{291}$ A Charismatic Lutheran, Christenson explores what is one of the

\footnotetext{
${ }^{289}$ Karl Barth, Evangelical Theology: An Introduction, trans., Grover Foley (Grand Rapids: Eerdmans, 1963), 63.

${ }^{290}$ Methodologically, we begin with Larry Christenson's work for three reasons. First, his work, again, not the first in the Charismatic tradition, is a culmination of a number of important texts on social action from the Charismatic tradition as evidenced by his very helpful bibliography. His work is largely a crossroad of many Charismatic voices of his time. Secondly, while not a text on ecotheology directly, it is evidential within PC traditions of the rumblings of the Spirit's role in caring for the social/justice needs of the world. Historiographically it has been utilized by a number of important PC ecotheological works since. And thirdly, it opened the door for new social visions fueled by the Spirit in his tradition. Larry Christenson, $A$ Charismatic Approach to Social Action (Minneapolis: Bethany Fellowship, 1974).

${ }^{291}$ John Taylor, an Anglican missionary, synthesized his pneumatology with a "cosmic oneness" where God is intimately interrelated with all creation. This text reflects a newfound appreciation for African theologies as well as a disdain for the "High God" that never touches the cosmos. This "go-between God"
} 
preliminary attempts at an explicitly Charismatic approach towards social action based almost entirely on a pneumatology keenly sensitive to the work of Charismatic RC Kilian McDonnell. McDonnell, a pillar in the RC Charismatic movement as well as the RCPentecostal dialogue, has assisted PCs to participate in the social justice tasks of his day. ${ }^{292}$ Drawing on McDonnell, this "Spirit-filled" approach to social justice derives itself from, what Christenson calls, "a charismatic approach to social issues... which is both initiated and carried out in the power of the Holy Spirit." 293 That is to say that all social action is authored initially by the Spirit of God, and secondly by human agency. The mechanism of Spirit baptism, therefore, remains both a social/political force on a personal level and becoming the power for transformative practice on the cosmological level.

Developmentally, Christenson's impact in the Charismatic movement was not isolated. We can observe his theological influence on the later Pentecostal Murray Dempster whose social ethic was similarly important for emerging PC social theology. ${ }^{294}$ As a preliminary and surprisingly substantive broad attempt at a Charismatic social ethic

is therefore the Spirit, drawn from the OT, who draws all beings together in communion. John Taylor, The Go-between God: The Holy Spirit and the Christian Mission (London: SCM, 1972).

${ }^{292}$ His follow-up text was, Larry Christenson, Social Action Jesus Style (Minneapolis: Bethany Fellowship, 1976). Further, for the sketch of the theological, social, and Charismatic rubric of McDonnell's work as the backbone for much of the Charismatic social imagination, begin with Kilian McDonnell, The Holy Spirit and Power: The Catholic Charismatic Renewal (Garden City: Doubleday, 1975); Kilian McDonnell, Charismatic Renewal and the Churches (New York: Seabury, 1976); Kilian McDonnell, Presence, Power, Praise: Documents on the Charismatic Renewal (Collegeville: Liturgical Press, 1980); Kilian McDonnell, The Baptism of Jesus in the Jordan: The Trinitarian and Cosmic Order of Salvation (Collegeville: Liturgical Press, 1996), 50-68; Kilian McDonnell, The Other Hand of God: The Holy Spirit as the Universal Touch and Goal (Collegeville: Liturgical Press, 2003).

293 Christenson, A Charismatic Approach to Social Action, 11. Although many can be mentioned here, I am indebted to the work of Donald Gelpi, whose pneumatological construction illustrates the powerful force behind a charismatically engaging RC Trinitarian theology of the Holy Spirit. Gelpi, The Divine Mother. See also his Donald Gelpi, The Turn to Experience in Contemporary Theology (New York: Paulist, 1994); Gelpi, The Gracing of Human Experience.

294 See Dempster's bibliographic notation. Murray Dempster, "Pentecostal Social Concern and the Biblical Mandate of Social Justice,” PNEUMA 9.2 (1987), 129-153 (149). 
centered on Spirit baptism, Christenson's work is paradigmatic of the rumbling attitude at a time within PC traditions of developing openness to creative societal, political, scientific, and ecological imaginations of Spirit-filled praxis. Two important preliminary comments regarding Christenson's social theology are in order. First, Christenson, as with a cadre of others in the PC traditions, establishes a surprising openness and ability to draw from a variety of sources (such as the RC social theology of McDonnell) for their purposes within PC movements. To put it in pneumatological terms, it is evidence of a broader openness to the Spirit's voice in theological expressions both inside and outside their own walls of tradition. This illustrates a strong sense of ecumenical sensitivity, especially in regards to social justice. Secondly, Christenson's work illustrates a trajectory to which we will turn later in the literature that fastens a pneumatological emphasis (e.g. Spirit baptism) to social practice, transcending personal/individual soteriology to a more holistic cosmological soteriology.

An increased sensitivity to social justice priorities has undeniably arisen from Pentecostalism's newfound relationships with liberation theologies in this late modern globalized culture. ${ }^{295}$ Often existing side-by-side with PC communities, liberationist communities seek to deliver sustainable freedoms to oppressed peoples and lands. ${ }^{296}$ This

\footnotetext{
295 I would contend this is especially the case among the RC liberationists in the South and their baseecclesial communities. On this liberationist/PC connection, see Juan Sepulveda, "Pentecostal Theology in the Context of the Struggle for Life," in Faith Born in the Struggle for Life: A Rereading of Protestant Faith in Latin America Today, ed. Dow Kirkpatrick (Grand Rapids: Eerdmans, 1988), 298-318; Juan Sepulveda, "Pentecostalism and Liberation Theology: Two Manifestations of the Work of the Holy Spirit for the Renewal of the Church," in All Together in One Place: Theological Papers from the Brighton Conference on World Evangelization, eds. Harold Hunter and Peter Hocken (Sheffield: Sheffield Academic Press, 1993), 51-64; Juan Sepulveda, "Future Perspectives for Latin American Pentecostalism," IRM 87.345 (1998), 189-195.

${ }^{296}$ As an example, for an important examination of how Pentecostals are playing a key role in the Chilean religious scene, see Lene Sjorup, "Pentecostals: The Power of the Powerless," DG 41.1 (2002), 16-25. For a broader look at the entirety of South America, Andre Corten and Ruth Marshall-Fratani, Between Babel
} 
is no more true than in Latin America where Pentecostalism and Evangelicalism have increasingly numerically thrived living in the same space as RC ecclesial base communities. While the raison d'être for this numerical influx is difficult to explain, some have attempted to undertake an explanation. For instance, David Stoll argued that Latin American Evangelicalism has grown — among other things— due to the perceived shortcomings of RC. ${ }^{297}$ While this may be true for Evangelicalism, it does little to account for the phenomenal growth of PC in the same regions unless we underscore the connection between PC and Evangelicalism. It continues to appear that PC movements have an acute ability to spread in traditionally RC cultures, creating, at times, ecclesial clashes between the two. Why some ecclesial challenges between the two remains unsettled, what is clear is an ongoing interconnected relationship is being established between Pentecostal and liberation theologies in these regions. It is important that we highlight said liberation theologies' impact on global Pentecostalism. A liberationist emphasis on ethical living, freedom of the oppressed, and in many cases the defense of rainforests, water supplies, and farmland protection has undeniably shaped, on some level, PCs in those regions into more socially-minded communities. Let us examine this dialectical relationship between Pentecostalism and liberationist theology.

and Pentecost: Transnational Pentecostalism in Africa and Latin America (Bloomington: Indiana University Press, 2001); M. D. Litonjua, "Pentecostalism in Latin America: Scrutinizing a Sign of the Times," JHLT 7.4 (2000), 26-49; Benjamin Valentin, New Horizons in Hispanic/Latino Theology (Cleveland: Pilgrim Press, 2003).

${ }^{297}$ David Stoll, Is Latin America Turning Protestant?: The Politics of Evangelical Growth (Berkeley: University of California Press, 1990). David Martin illustrates for us the growth of Pentecostalism in Latin America with particular attention to the conflicts it has created. David Martin, Tongues of Fire: The Explosion of Protestantism in Latin America (Oxford: Blackwell, 1989). 
Miroslav Volf proposes an intriguing comparative study of the soteriological frameworks of Pentecostals and liberation theologies. ${ }^{298}$ As with Dempster and Villafañe after him, Volf will highlight not only the importance of these two exponentially growing forms of the Christian expression in the two-thirds world, but their theological similarities and differences. Volf points out that while opposed in many regards, the two agree in this: emphasizing what Volf calls "the materiality of salvation." ${ }^{299}$ For Pentecostals, this materiality is centered on "the transcendence of God and God's activity as coming down from above. ${ }^{300}$ Comparatively, this is in stark contrast with liberation theologies, whose foci remains on the material, on the "immanence of God and God's activity in history from below." ${ }^{301}$ The difference in these approaches is seen in liberation theologies' primary focus on the socioeconomic transformation of society while the Pentecostal's focus has a future salvific emphasis. Simply put, for the liberationist, Christian praxis becomes "immersion into the world," not a blatant escaping from it. ${ }^{302}$ Pentecostals, on the other hand, often emphasize salvation individualistically, which eventually leads to the possibility of a changed society. All of this, again, arises from two vastly different eschatological visions where liberationists envision the transformatio mundi ("transformation of the world") while Pentecostals the anihilatio mundi

\footnotetext{
${ }^{298}$ Miroslav Volf, "Materiality of Salvation: An Investigation in the Soteriologies of Liberation and Pentecostal Theologies," JES 26.3 (1989), 477-467. This two-sided soteriology can be seen elsewhere. Yong, calling this the "multidimensionality of salvation," comments, "My main thesis is that Christian salvation includes both the transformation of human beings into the image of Jesus by the power of the Holy Spirit and the transformation of all creation into the new heaven and new earth by the triune God." Yong, The Spirit Poured out on All Flesh, 91, (italics mine).

${ }^{299}$ Volf, "Materiality of Salvation."

300 Ibid., 447-448.

301 Ibid., 447.

${ }^{302}$ Ibid., 448.
} 
("destruction of the world"). ${ }^{303}$ In a later article on vocation, Volf contrasts Paul's language of a creational liberation in Romans 8 to the destruction of creation emphasized by Pentecostalism. ${ }^{304}$ In that text, Volf agrees with F.F. Bruce who writes, "If words mean anything, these words of Paul denote not the annihilation of the present material universe on the day of revelation, to be replaced by a universe completely new, but the transformation of the present universe so that it will fulfill the purpose for which God created it." ${ }^{305}$

This illustrates a vital difference between liberationist and Pentecostal theologies which seem to have very little in common, a result perhaps of Luther's two-nature thesis of the human person dichotomized as the "inner" and "bodily" person. ${ }^{306}$ Here is where Volf devotes the primary section to the idea of nonmaterial salvation: first within Lutheran Protestantism, with two later succeeding sections on the "materiality of salvation" in Pentecostalism and liberation theology. Volf concludes that liberation theology envisions a world healed by the praxis-centered gospel while Pentecostals envision the healing nature of the Spirit in the individual's life. Ultimately, for Volf, the former is a neglected element of the Pentecostal message. ${ }^{307}$ To represent his case, he points to an absence of the healing motif in many Pentecostal theologies such as that of

\footnotetext{
303 These two concepts are resplendent throughout his work and offer counter images of how eschatology shapes Christian praxis in the world. Contrasted to the anihilatio Dei, N.T. Wright, The New Testament and the People of God (Minneapolis: Fortress, 1992), chap. 10.

304 Miroslav Volf, "Human Work, Divine Spirit, and New Creation: Towards a Pneumatological Understanding of Work," PNEUMA 9.2 (1987), 173-193.

${ }^{305}$ F.F. Bruce, The Epistle of Paul to the Romans: An Introduction and Commentary (Grand Rapids: Eerdmans, 1963), 170.

306 Volf, "Materiality of Salvation," 449-453. Historically, Volf situates this dualism of the "inner" and "outer" in Luther's The Freedom of a Christian, in which he makes a differentiation between the two. Martin Luther, Three Treatises: An Open Letter to the Christian Nobility, trans., Charles Jacobs, A.T.W. Steinhauser, and W.A. Lambert (Philadelphia: Fortress, 1960).

${ }^{307}$ Here he quotes Raymond Pruitt who argued that the doctrine of the healing of the physical body is "the neglected half of the gospel." See Pruitt, Fundamentals of the Faith, 318-319.
} 
Duffield and Van Cleave's Foundations of Pentecostal Theology. ${ }^{308}$ For Volf, this absence comes as a "surprise for authors who belong to the church that believes that divine healing is 'one-forth of the Foursquare gospel." ${ }^{\prime 309}$ But it is ultimately a larger problem for all of Pentecostalism who tend to have a strong theology of healing without a practice of it. As a final construction, Volf attempts to fill this void by identifying four strains of a renewed responsible Pentecostal soteriology: personal-spiritual, individualphysical, socioeconomic, and ecological. ${ }^{310}$ Responsible soteriology, Volf contends, is one that will care about "nature and its integrity." ${ }^{311}$ And this expanded soteriology, in line with Jesus's proclamation of the year of the Lord (Luke 4:19), will inevitably lead to the year of Jubilee when "the fields lay fallow." ${ }^{312}$

A continued illustration of this transformative soteriology is Volf's oeuvre into a vocational pneumatology, offering an economic polemic against a Weberian "Protestant Work Ethic" framework. ${ }^{313}$ Volf, in deconstructing modern paradigms of Western vocation, contends that economic systems should be adjudicated on three points: "Freedom of individuals, satisfaction of the basic needs of people, and protection of

\footnotetext{
${ }^{308}$ Duffield and Van Cleave, Foundations of Pentecostal Theology.

${ }^{309}$ Here, Volf sarcastically quotes Guy Duffield and Van Cleave, the theologians/academics from the International Church of the Foursquare Gospel (Foursquare) who wrote the seminal denominational text, which continues to play a significant role within the movement. See ibid., 173-260.

${ }^{310}$ Volf, "Materiality of Salvation," 467.

${ }^{311}$ Ibid., 466. Volf expanded these pneumatological themes, later culminating in his full-fledged pneumatological vision of work. First introduced in an article in 1987, this vision finds its eventual fullfledged development in his 1991 book. See both Miroslav Volf, "Human Work, Divine Spirit, and New Creation: Toward a Pneumatological Understanding of Work," PNEUMA 9.2 (1987), 173-193; Volf, Work in the Spirit: Toward a Theology of Work.

${ }^{312}$ Volf, "Materiality of Salvation," 466.

${ }^{313}$ Miroslav Volf, Work in the Spirit: Toward a Theology of Work (Eugene: Wipf and Stock, 1991). For Weber's original work, see Max Weber, The Protestant Word Ethic and the Spirit of Capitalism (New York: Penguin, 2002).
} 
nature from irreparable damage." 314 Ultimately, Volf argues, vocation and human production should be judged on a pneumatological basis, not an economic one, as has capitalism. ${ }^{315}$ Thus, a Spirit-centered approach will critically engage any economic system that does not perpetuate and sustain all forms of life. In other words, if life is not sustainable, pneumatology must critique it. Although it is unclear what impact Hollenweger's pneumatological shift had on him, Volf's economic pneumatology compares quite strongly with the trajectory of Hollenweger's pneumatology. ${ }^{316}$ Of similar persuasion is Yong's disability theology and Maxine Gernert's pneumatology which is employed for domestic abuse issues and offers a pneumatological-centeredness that can find value in a number of issues paralleled by Volf. ${ }^{317}$

Societal justice, ecological ethics, and equitable/sustainable living are unquestionably central tenets of liberation theology. Chilean Pentecostal Eldin Villafañe's extensive research has greatly assisted PC scholarship by bringing such liberationist voices of South America to the Pentecostal discussion table. ${ }^{318}$ Villafañe describes these liberation forms of gospel living, which base creation care on the dignity

\footnotetext{
${ }^{314}$ Volf, Work in the Spirit, 15. See also Volf, "Human Work, Divine Spirit, and New Creation."; Miroslav Volf, "A Rhythm of Adoration and Action," in All Together in One Place: Theological Papers from the Brighton Conference on World Evangelization, eds. Harold Hunter and Peter Hocken (Sheffield: Sheffield Academic Press, 1993), 38-45; Miroslav Volf, “God at Work,” WW 25.4 (2005), 381-393.

${ }^{315}$ Volf writes, "My thesis is that all our own needs or the needs of our fellow creatures should be understood from the perspective of the operation of the Holy Spirit." Volf, "Materiality of Salvation," 174.

${ }^{316}$ Especially Hollenweger's theology in Walter Hollenweger, "All Creatures Great and Small: Towards a Pneumatology of Life," in Strange Gifts?: A Guide to Charismatic Renewal, eds. David Martin and Peter Mullen (Oxford: Blackwell, 1984), 41-53.

${ }^{317}$ Maxine Gernert, "Pentecost Confronts Abuse," JPT 17 (2000), 117-130; Yong, Theology and Down Syndrome. See also David Batstone, et. al., Liberation Theologies, Postmodernity, and the Americas (New York: Routledge, 1997).

${ }^{318}$ Eldin Villafañe, The Liberating Spirit: Toward an Hispanic American Pentecostal Social Ethic (Grand Rapids: Eerdmans, 1993); Villafañe, "The Contours of a Pentecostal Social Ethic: A North American Hispanic Perspective," TR 11 (1994), 6-10;Villafañe, "The Politics of the Spirit: Reflections on a Theology of Social Transformation for the Twenty-First Century," PNEUMA 18.2 (1996), 161-170;
} 
of creation as the effort "to free from all enslavement, be the moral or spiritual, ecological or ecclesiastical, economic or political." ${ }^{, 319}$ Villafañe's extensive and sweeping research has suggested over and over again that Pentecostal spirituality, embodied in such cultures (e.g. Chile), engenders a religious/political climate concentrated on a sort of holistic soteriology; a soteriology stressing salvation of the soul/spirit and a deep and sincere desire for the salvation of the entire world. ${ }^{320}$ This soteriological holism will often lead Villafañe to situate an ethical program to the forefront of his pneumatology. For example Villafañe suggests that while Hispanic Pentecostalism has been intent on trying to overcome the cosmos ("world" of sin), pneumatology in the same breath must "affirm the goodness of God's creation which includes human culture and its history."321 That is to say the ultimate goal is "to be a community of the Spirit in the world and a community of the Spirit for the world." 322

Similarly important in this regard is Juan Sepulveda's illuminating and extensive engagement of the Marxist-centered paradigm of Southern liberation theologies. ${ }^{323}$ Sepulveda and Villafañe have both shown how a robust PC spirituality that exists in close contact with liberation theology, especially in Latin American cultures, can produce communities deeply engaged in the social justice and care of their local settings. Where the liberation fronts in South America and Minjung theology in Korea have been shaping the landscape for decades, it must be agreed in the line of Charles Briggs and brought to

\footnotetext{
319 Eldin Villafañe, "The Politics of the Spirit," 162, (italics mine).

320 This is the overall theme of Eldin Villafañe, The Liberating Spirit.

321 Ibid., 188.

322 Ibid., 196.

323 Sepulveda, "Pentecostalism and Liberation Theology." See also, as an example, on Pentecostalism in Chile, Edward Cleary and Juan Sepulveda, "Chilean Pentecostalism: Coming of Age," in Power, Politics, and Pentecostals in Latin America, eds. Edward Cleary and Stewart-Gambino (Boulder: Westview, 1997), 97-121.
} 
the forefront by William Faupel that in these contexts, "theology is incarnational." 324 That is, the previous lines drawn between theology and practice can no longer be separated. Theology must be developed among people and the human struggle for freedom.

Finally, Pentecostal social justice theology has been shaped by the many cultural, ethnic, and theological traditions it has encountered through its contact in the African Charismatic movements, such as the AICs (African Independent Churches). Regarding this Pentecostal expansion, what began as a phenomenological North American emergence has quickly morphed into a very non-North American tradition. ${ }^{325}$ This is perhaps the case because PC movements resonate well in African cultures and religious practice where charismatic, experiential, and ecstatic expression is by nature the homo religiosus of the African sphere. Previous to early-twentieth century American Pentecostal revivalism (Topeka and Los Angeles), "Pentecostal-like" revival erupted with monumental numbers throughout the African sphere, similar to the manifestations of that taking place in Wales prior to Parham and Seymour's emergence in North America. ${ }^{326}$ It is here that William J. Seymour remains central to the story of Pentecostal social justice theology. Jean-Jacque Suurmond has suggested that Seymour's two main fusions into Pentecostalism are vital to its establishment: evangelical Holiness and African

\footnotetext{
${ }^{324}$ William Faupel, “Whither Pentecostalism,” PNEUMA 15.1 (1993), 9-27 (13).

325 Again, I utilize here Philip Jenkins's analysis of Pentecostalism's wide-ranging spread to the South and East. Jenkins, The Next Christendom; Jenkins, The New Faces of Christianity. Steven Land agrees, suggesting that Pentecostalism had emerged largely as a North American phenomenon, but it has subsequently become a mostly non-North American faith. Steven Land, Pentecostal Spirituality: A Passion for the Kingdom, JPTSup, vol. 1 (Sheffield: Sheffield Academic Press, 1994).

326 It is believed that AIC's pre-1900 in Africa numbered nearly 900,000 with similar "Spirit-centered" activity similar to that seen in Azusa Street revival. S.M. Burgess and M. van der Maas, eds., NIDPCM, xx.
} 
Spirituality. ${ }^{327}$ Seymour undoubtedly played a powerful role in the development of a more communal and holistic soteriology marked by African ecclesiology at Azusa Street. It should, therefore, come as no surprise that Pentecostal spirituality has had significant influx on the African continent with its similar emphasis on praxis-centered spirituality, the Spirit's ongoing activity throughout creation, and oral theology.

Although African Charismatic pneumatology is notoriously challenging to assess due to being often constructed in a ritualistic/oral way often shying away from written mediums, it has played a key role in Pentecostal ecotheology identity. David Albrecht helpfully appraises the ritualistic nature of Pentecostal worship serving as a salient connection in contrasting African spiritualities and PC worship, practice, and theology in their oral nature. ${ }^{328}$ Albrecht argues that both PCs and African oral-theologians are less likely to publish theology than simply let it be the oral tradition of their community of faith. With this emphasis on oral tradition, especially in Third World forms of Pentecostalism, it does not lend itself to synthesis with ecological issues being deeply informed in written tradition. Nonetheless, regarding this connection, African spirituality has had an important effect on Pentecostalism in regards to sparking dialogue around ecological justice issues. ${ }^{329}$ Perhaps this is due to what I call a rich immanent

\footnotetext{
327 Jean-Jacques Suurmond, Word and Spirit at Play: Towards a Charismatic Theology (Grand Rapids: Eerdmans, 1995). The Holiness code is, in Synan's words, “Arminian in theology and Wesleyan in their view of sanctification." Vinson Synan, The Holiness-Pentecostal Tradition: Charismatic Movements in the Twentieth Century (Grand Rapids: Eerdmans, 2000), 81.

${ }^{328}$ For an excellent treatment on the "rites" and ritualistic nature of Pentecostalism, see Daniel Albrecht, Rites in the Spirit: A Ritual Approach to Pentecostal/Charismatic Spirituality, JPTSup, vol. 17 (Sheffield: Sheffield Academic Press, 1999).

${ }^{329}$ Again, as articulated at the beginning of this chapter, Hollenweger surmised there were five roots to the Pentecostal movements. Here I highlight the black oral root largely coming from African spirituality and slave trade currents arriving from Africa post-Azusa Street revival. See the very helpful Hollenweger, Pentecostalism.
} 
pneumatology emphasizing the Spirit's active and ongoing role in the world. Although this immanence is accentuated more in ecological terms regarding African spirituality than it has in historical Pentecostalism.

African Charismatic Christianity envisions the entire world as a world of the mystical Spirit. Gary Babcock argues that African spirituality, like Pentecostalism, from its earliest roots is based on wholeness. ${ }^{330}$ This immanent pneumatology leads to a powerful sense of spiritual wholeness in the ecological world. We see this holism exemplified in the African Charismatic movements that have put forth various efforts at wholeness in ecological practice. M.L. "Inus" Daneel, South African missiologist and scholar on the AICs (African Independent Churches), founded both the AZTE (Association of Zimbabwean Traditional Ecologists) in 1989 and the AAEC (African Association of Earth-Keeping Churches) in $1991 .{ }^{331}$ In particular, the AAEC serves as an organization of grassroots, tree-planting Charismatic churches spanning over 180 African independent denominations. Contextually, as the African continent appears to be experiencing excelled levels of ecological crisis in comparison to other parts of the world, African PCs in the AICs have been forced to develop ecotheology to face issues such as forest demise, overpopulation, and drought, matched with the added strain of low income and high poverty. ${ }^{332}$ Daneel accounts for their efforts in a number of important texts, exploring how the South African AICs have shown themselves a powerful force for liberative causes in ecological stewardship through the teaching of responsible farming

\footnotetext{
${ }^{330}$ Quoted in Anderson, An Introduction to Pentecostalism, 197.

${ }^{331}$ For a helpful introduction to the AICs on the African continent, see M. L. Daneel, Quest for Belonging: Introduction to a Study of African Independent Churches (Gweru: Mambo Press, 1987).

${ }^{332}$ See the helpful David Roebuck, "Pentecostalism at the End of the Twentieth Century: From Poverty, Promise and Passion to Prosperity, Power and Place," in Religion in the Contemporary South, Changes, Continuities, and Contexts, ed. Corrie Norman (Knoxville: University of Tennessee Press, 2005), 53-73.
} 
practices, ecological sensitivity, and soil conservation. All of this takes place, writes

Daneel, despite their "unwritten yet convincingly enacted theologies of human

liberation." $" 333$

There are a number of important ways ecological liturgies in the AICs are literally shaping the landscape in Africa, suggests Daneel. After the planting of the tree, there is a communal public confession of ecological sins, "such as tree-felling, causing soil erosion through riverbank cultivation and the use of sledges." 334 This has a deep effect. First, the sheer size of the AICs is proving to be a massive contributor both to political and practical power schemata in the region. ${ }^{335}$ The AICs also tend to be liberative movements frequently led by "messianic" figures, often men with remarkable power in a region, whose passions conjure up great zeal among the people. ${ }^{336}$ Daneel points out that this ecological passion is often birthed in the socioeconomic stresses of being a liberated people from the colonial powers, which once controlled them. And it is this drive from colonialism which often compels the ecological care movement as doing for the creation what God had done for them: freedom from the oppressors. AICs still largely remain to

\footnotetext{
${ }^{333}$ M.L. Daneel, "Towards a Sacramental Theology of the Environment in African Independent Churches," TE 24 (1991), 2-26 (2). On the liberative function of these groups, see M. L. Daneel, "Liberative Ecumenism at the African Grassroots," in Full of Life for All: Challenges for Mission in the 21st Century, eds. M.L. Daneel, Charles Engren, and Henrik Vroom (New York: Rodopi, 2003), 295-327.

${ }^{334}$ M.L. Daneel's helpful article as an overview of the AAEC can be found online at: $\mathrm{http} / / / 66.218 .69 .11 / \mathrm{search} / \mathrm{cache}$ ei=UTF8\&p=African+Earthkeeping + Church\&fr=moz2\&u=www.clas.ufl. edu/users/bron/PDF--Christianity/Daneel--

African\%2520Earthkeeping\%2520Churches.pdf\&w=african+earthkeeping+church+churches\&d=KBCI_52 uSSCk\&icp=1\&.intl=us, (accessed March 3, 2009).

${ }^{335}$ For instance, Daneel points out that the AICs cover nearly 4,000 churches, which is in total about thirty to forty percent of the total black population of Africa. These grassroots organizations have power simply by numbers alone. Daneel, "Towards a Sacramental Theology of the Environment in African Independent Churches," 4.

${ }^{336}$ Ibid.
} 
be rural movements that continuously stay in touch with the African landscape. ${ }^{337}$ This intimate land relationship births an oral theology of creational soteriology. Daneel again recounts the baptismal formula in AAEC liturgy whereby, along the Jordan River in Zimbabwe, new Christians will declare their conversion to Christ, be baptized, eventually marching around a large fire. This "environment-related sacrament" called Maporesanyika, often culminates in repentance from ecological sins such as cutting down too many trees that year. ${ }^{338}$ Similarly, the Eucharist is employed as a reminder of the human connection with the entire cosmos, which often follows with a tree-planting ceremony where the community will attempt to birth new life as a sacrament of creation.

Asamoah-Gyadu examines this same strain in West African creation theologies, focusing on the theologies of the AICs proliferating in the early-twentieth century and marking themselves as one of the driving forces of charismatic Christianity on the African continent. ${ }^{339}$ He highlights one such text of the late and illiterate Ghanaian (Akan) Afua Kuma. Kuma's Jesus of the Deep Forest resituates Christology for ecological hermeneutics in the setting of charismatic spirituality. ${ }^{340}$ The female Kuma, from the forest town of Obo-Kwahu on the Eastern corner of Ghana, articulates liberative ecological prayers and liturgy (despite her illiteracy) depicting a Jesus living in the African forest. Clearly, her theological paradigm parallels the cultural Ghanaian respect for the environment in which they live. However, this creates two challenges in

\footnotetext{
337 Ibid., 5.

338 M. L. Daneel, "Earth-Keeping Churches at the African Grass Roots," in Christianity and Ecology. eds. Dieter Hessel and Rosemary Ruether (Cambridge: Harvard University Press, 2000), 533-534.

339 J. Kwabena Asamoah-Gyadu, "God's Law of Productivity: Creation in African Pentecostal Hermeneutics," in The Spirit Renews the Face of the Earth, ed. Amos Yong (Eugene: Pickwick, 2009), 175-190.

340 Afua Kuma, Jesus of the Deep Forest (Accra: Asempa, 1981).
} 
attempting to define such creational theology by its own dual nature: orality and lacking written academic rigor; ${ }^{341}$ both of which has not hurt their influence. Jürgen Moltmann claims to develop his own pneumatological ecology based in dialogue with such theology. $^{342}$

There is an eschatological dimension to PC social justice theology. Within this emerging Pentecostal ecotheology there remains a metatension within the literature of an area Pentecostals and liberationists largely differ: eschatology. This is represented by Assemblies of God social ethicist Murray Dempster. ${ }^{343}$ For, as we have seen, PC traditions often mesh with social justice praxis found in many liberation theologies. Yet a strong ensconced theological suspicion in Western PCs concerning the overall intention and vision of liberation theology often argues that this sort of work somehow takes away from the real gospel of Jesus Christ. This suspicion leads to what Dempster has hailed a Pentecostal "social quietism" of nonaction based primarily on fear and ignorance. ${ }^{344}$ Ultimately, as Dempster and others have pointed out, this fear is often driven by a vastly different eschatological vision based on similarly diverse assumptions. A tension exists between the two: Pentecostalism has been packing their bags for Christ's return from childhood while liberationists realize we may be here for some time so why not settle in. This theological divergence both contributes substantially to how the two often exist in

\footnotetext{
341 J. Kwabena Asamoah-Gyadu, "God's Law of Productivity," 178.

342 Jürgen Moltmann, “A Response to My Pentecostal Dialogue Partners," JPT 4 (1994), 59-70 (61). Thanks to Matthew Tallman for this observation in his Matthew Tallman, "Pentecostal Ecology: A Theological Paradigm for Pentecostal Environmentalism," in The Spirit Renews the Face of the Earth, ed. Amos Yong (Eugene: Pickwick, 2009), 135-154.

343 Murray Dempster, "Christian Social Concern in Pentecostal Perspective."

344 Dempster, "Christian Social Concern in Pentecostal Perspective," 52.
} 
praxis. ${ }^{345}$ Rightly, Dempster has articulated this and argued that immanent views of eschatology, juxtaposed to liberationist theologies, would unanimously lead to this "social quietism."

Ultimately, for Murray, the integral significance of eschatological social justice praxis and ignorance results from a premillenial eschatology that has lured Pentecostalism to forget such social issues for the "larger" ones of soul-saving. ${ }^{346}$ But Murray finds hope in identifying subtle adaptations within Pentecostalism and a multiplication of social programs rivaling other traditions. ${ }^{347}$ To this end he attempts to "resolve this uneasy tension between belief and practice...highlighting the eschatological significance of Christian social service and action. ${ }^{348}$ Murray does this in two ways.

First, using an Acts 2 hermeneutic, Murray identifies key concepts within Pentecostal theology that embrace such forms of social action. Secondly, he argues that eschatology should, instead of putting off social concern, fuel new levels of social action. ${ }^{349}$ Dempster concludes that Pentecostalism does have the power to be a significant social force resonating with the visions of Pentecostal Paul Pomerville ${ }^{350}$ and George Eldon Ladd's ${ }^{351}$

\footnotetext{
345 As I have already argued, there are many cases where PC traditions have worked with, in, and alongside liberationist fronts. The line between the two is increasingly harder and harder to distinguish and in no way assumes they are two distinct separable entities.

${ }^{346}$ This rather pessimistic view is summed up succinctly in Dempster's article, commenting, "Social concern may feed the hungry and clothe people but when the trumpet sounds and nobody rises what do you have?" Dempster, "Christian Social Concern in Pentecostal Perspective," 54. He qualifies himself, saying this is of course the case with exception to a "sprinkling of leaders." Ibid., 52.

${ }^{347} \mathrm{He}$ calls this a "mushrooming growth of social programs" among Pentecostals. Initially it is difficult to identify which social initiatives he is attempting to point to, as his article omits them. It would be an interesting addition to this study to hear his examples of such growth. Ibid., 53.

${ }^{348}$ Ibid., 54.

${ }^{349}$ In a related fashion, we find a similar model for this in Frank Macchia's work. Frank Macchia, Spirituality and Social Liberation: The Message of the Blumharts in the Light of Wuerttemberg Pietism, Pietist and Wesleyan Studies, vol. 4 (Metuchen: Scarecrow Press, 1993).

${ }^{350}$ Paul Pomerville, The Third Force in Missions: A Pentecostal Contribution to Contemporary Mission Theology (Peabody: Hendrickson, 1985).
} 
Kingdom-based theologies, stressing the "already/not yet" nature of Kingdom living and social care fueled eschatologically that will readily lead to a more holistic soteriology of the whole person and creation. ${ }^{352}$

\section{Regarding liberation theology, Dempster uses a Pentecostal framework to} reconfigure social justice as a necessary imperative to Spirit-filled witness. This could potentially match liberation efforts as mentioned in Minjung theology and Latin America to Pentecostalism. ${ }^{353} \mathrm{He}$ establishes this by utilizing OT narrative as a basis for social ethics based on five ethical OT "guiding" principles, in turn instigating a Pentecostal social justice: a theocentric foundation, the imago Dei, God's people as a covenant people, the prophetic tradition of social criticism, and Jubilee teachings. ${ }^{354}$ Following a corresponding biblical exegesis of each, he proposes a synthesis with Pentecostal theology intending to integrate it "into a distinctively Pentecostal social ethic grounded in the Luke-Acts interpretation of Spirit baptism.. ${ }^{355}$ This creative approach utilizing the

\footnotetext{
${ }^{351}$ See both seminal works in George Ladd, The Presence of the Future: The Eschatology of Biblical Realism (Grand Rapids: Eerdmans, 1974); George Ladd, A Theology of the New Testament, (Grand Rapids: Eerdmans, 1993).

352 Dempster puts it well: "Maranatha, the coming of the Lord, should therefore fuel the fires of the church's social concern with the same intensity that this hopeful expectation has historically brought to the task of evangelism." Dempster, "Christian Social Concern in Pentecostal Perspective," 64, (italics mine).

This is helpfully developed in Scot McKnight, Embracing Grace: A Gospel for All of Us (Brewster: Paraclete, 2005), 79-82.

${ }^{353}$ Dempster, "Pentecostal Social Concern and the Biblical Mandate of Social Justice," 129. Dempster, in the first line of his article, makes two preliminary points. First, Pentecostals must learn to enter social justice on a more substantive way. As well, this social justice is an element of the "evangelistic outreach" of the Pentecostal churches. He continues, "Recognition is expanding in Pentecostal circles that the church's mission and ministry of evangelism should be augmented to include a commitment to social justice." As mentioned, he later terms this growth in social justice a "coming of age for Pentecostals." Dempster, "Christian Social Concern in Pentecostal Perspective," 53.

${ }^{354}$ Ibid. For Dempster, the Spirit thus becomes the agent by which these five OT social justice themes can be practiced, writing, "In the coming of the Spirit at Pentecost, therefore, the long story of God's will for justice found an empowering dynamic." Ibid., 148.

${ }^{355}$ Ibid., 129.
} 
Hebrew tradition in PC categories demonstrates promise on various levels. ${ }^{356} \mathrm{He}$ concludes with a call for a social ethic to reach into a Pentecostal doctrine of creation, although, again, sadly never truly interacting with the ecological crisis in-depth. ${ }^{357}$ For its worth, Dempster proposes a framework for Pentecostal social imagination beyond "endtimes" apocalypticism to a more constructive "here and now" view of the Kingdom of God. We see a continued reflection by Dempster six years later in his "Christian Social Concern in Pentecostal Perspective: Reformulating Pentecostal Eschatology,” reminiscing on the original social theology of Ernst Troeltsch in the 1960s. ${ }^{358}$

\subsubsection{PC Spirit/Creation Approaches}

Now we will examine a number of works and voices that have shaped a Spirit/creation theology within Pentecostal theology. To begin, we turn our attention to Hollenweger's evaluation of global pneumatology in the shaping of PC theology. ${ }^{359}$ In particular, the

\footnotetext{
${ }^{356}$ I would contend this synthesis is representative of two major important trajectories of future Pentecostal ecotheology. First, Pentecostal social ethics are often informed primarily with NT developments to the expense of the Hebrew tradition. In terms of ecotheology, this move will be necessary to capture the theme of the Spirit (rûach) in the Hebrew Bible. But secondly, it opens the pneumatological door to capture a cadence of the Spirit's work previous to and preceding the Acts 2 narrative.

${ }^{357}$ Ibid., Dempster, "Pentecostal Social Concern and the Biblical Mandate of Social Justice," 133. Clearly the ecological crisis as we know it was not as public a predicament in 1987 as it is today.

${ }^{358}$ Dempster, "Christian Social Concern in Pentecostal Perspective." For Troeltsch's original work, examine his Ernst Troeltsch, The Social Teaching of the Christian Churches (New York: Harper and Row, 1960).

${ }^{359}$ Walter Hollenweger, "Creator Spiritus: The Challenge of Pentecostal Experience to Pentecostal Theology," Theology 81 (1978), 32-40. For an informative analysis of Hollenweger's rûach theology, see Price, Theology Out of Place, chap. 6. Hollenweger does not surmise Pentecostalism alone has brought pneumatology to the forefront. Rather, it has simply been a strong force in this endeavor. He commences his article arguing, that along with Pentecostalism, the Charismatic renewal, RC pneumatology, and a growing stream of literature on the Holy Spirit and PC spirituality have contributed to this resurgence of pneumatology. He writes, "It is no secret that the Pentecostal churches have so far not produced a Charismatic theology. Even their doctrine of the Spirit is nothing new and often only a weak rehash of the position of the Holiness Movement of the $19^{\text {th }}$ century, dressed up with the doctrine of 'initial evidence' (speaking in tongues), which characterizes the baptism of the Spirit. It is my conviction that the
} 
former professor of mission and Pentecostalism at the University of Birmingham (UK) examined Pentecostal rippling effects amongst the mainline traditions and its reappraised pneumatology with a resultant charismatic view of a Spirit/cosmos relationship. Through an exegesis of the NT Pauline charismata motif, Hollenweger forwards a stimulating case for the dynamic pneumatology of Pentecostal theology as a paradigm for a broader ecumenical global pneumatology ${ }^{360} \mathrm{He}$ suggests that Pentecostalism's lack of written theology—relying mostly on an experiential oral spirituality—offers an experiential charismatic theology that makes room for diversity in faith and gifting while remaining an accommodating corrective to all expressions of Christian theology ${ }^{361}$ Moreover, for our purposes, he platforms the OT Spirit-narratives, which he believes offer a strengthened platform for understanding the ubiquitous Spirit that cannot be monopolized by the institutional church and must be understood in the context of the larger world. Then he moves to the NT Spirit-discourse. Here, Hollenweger argues that charismata (speaking in tongues, miraculous healing by the laying on of hands, and parapsychological phenomenon) should rightly fall under the categories of the Spirit's work in the world, not just the charismatic church. In essence, Hollenweger offered PC theology space to imaginatively construct a pneumatology extra ecclesia, or the Spirit's

Pentecostals' theological articulation does not adequately represent their practices and experience." Hollenweger, "Creator Spiritus," 34.

${ }^{360}$ Ibid., 32. As well, in this short yet stimulating article, Hollenweger offers a brief extrapolation of "speaking in tongues and a charismatic understanding of the world," as well as the relationships between the Western and Third World churches. A significant study of the overall hermeneutical lens of Pauline creation theology can be found at David Horrell, Cherryl Hunt, and Christopher Southgate, Greening Paul: Rereading the Apostle in a Time of Ecological Crisis (Waco: Baylor University Press, 2010).

${ }^{361}$ Hollenweger, "Creator Spiritus," 32-36. 
work outside the church. He later will call this charismatic theological framework "a theology of the world." 362

This "theology of the world" theme reemerges in a later Hollenweger piece which juxtaposes Eastern pneumatology with PC spirituality. ${ }^{363}$ Hollenweger surmised that a roadblock to PC pneumatology is its derivative relationship to Western philosophical categories, sharing what he calls the "deficiencies of the pneumatologies of the Western tradition. ${ }^{364}$ In essence, for Hollenweger, the PC pneumatological apple had landed way too close to the Western tree. Cautiously aware that bemoaning the West has grown faddish in academia, Hollenweger reminds Pentecostals to humbly, yet intentionally, mindfully be aware of the Western logs in their theological eye. In the end, Hollenweger perceptively observes what is potentially one of the greater potential pitfalls to a Western Pentecostal ecotheology. He surmises that Western PC theology has privileged Western frameworks of theological and philosophical discourse (Baconian utilitarianism), having, whether intentional or not, more or less silenced Eastern influence. These silenced Eastern influences are, Hollenweger argues, traditionally constructed with a more dignified, mystical, and respectful view of nature. ${ }^{365}$ These "deficiencies" to which Hollenweger alludes remain a Western perennial loss of creation's Spirit-centeredness.

\footnotetext{
362 Ibid., 36.

${ }^{363}$ Walter Hollenweger, "All Creatures Great and Small.” Hollenweger followed this work with his Spirit and Matter in Walter Hollenweger, Geist Und Materie: Inerkulturelle Theology 3 (Munich: Chr. Kaiser Verlag, 1988).

${ }^{364}$ Hollenweger, "All Creatures Great and Small," 41, 44.

365 As we will see, this is not universally held by Pentecostals, as Edmund Rybarczyk has argued that Pentecostals and the Eastern Orthodox traditions share a deeply held common mystical theology, among others. Edmund Rybarczyk, Beyond Salvation: Eastern Orthodoxy and Classical Pentecostalism on Becoming Like Christ (Carlisle: Paternoster, 2004). On the modernist language and overall power of Baconian utilitarianism in this context, see Brian Wren, What Language Shall I Borrow? God-Talk in Worship: A Male Response to Feminist Theology (London: SCM, 1989).
} 
Creative Spirit-centered approaches in new and innovative formats have emerged in Pentecostal theology in recent years; and as we shall see, these are what Hollenweger looked forward to. ${ }^{366}$

Hollenweger continues, "If we understand the Holy Spirit as part of God's creation then he does not become a stopgap explanation for things not or not yet explained, but rather the root and fountain of everything, whether explainable or not explainable. ${ }^{״ 367}$ Hollenweger elsewhere suggested that the three major roadblocks to Pentecostal theology are all essentially paradigmatic pneumatological issues: ecological destruction, world trade, and the intersection of Pentecostal theology to spirituality. ${ }^{368}$ Although this "theology of the world" was never fully applied to the ecological issues of his time, it should be countered that such issues were only beginning to become culturally important at the time of this writing in 1978 with the emergence of Rachel Carson (1964) and Lynn White (1967) just previous. But this key work offers Pentecostals a sizeable launchpad for developing charismatic theology beyond the ecclesiological to the cosmological.

In a 1982 response to a call by Richard Mouw, J.T. Snell called for an expanded pneumatology based on the extended ending of Mark 16:15-20 as a basis for Pentecostal

\footnotetext{
${ }^{366}$ For instance, as an intriguing example of this, see Andrea Hollingsworth, "Spirit and Voice: Toward a Feminist Pentecostal Pneumatology," PNEUMA 29.2 (2007). Concerning a feminist Pentecostal pneumatology, it illustrates how Pentecostals are more readily engaging new areas of research previously unengaged. This would be an example to which I believe Hollenweger was referring, Spirit-centered theology.

${ }^{367}$ Hollenweger, "Creator Spiritus," 37.

${ }^{368}$ Walter Hollenweger, "Pentecostalism, Past, Present, and Future,” JEPTA 21 (2001), 45-46.
} 
ecological care ${ }^{369}$ Here, Snell recounts that the disciples are commanded to "Go into all the world and preach the good news to all creation" (Mark 16:15). Snell does this by attempting to sidestep the redactional and exegetical difficulties of the extended Markan passage in chapter 16. Drawing on the theology of both Abraham Kuyper and Mouw, Snell paints a fresh picture of the charismata as having significant ecological implications. He writes, "The regenerating activity of the Spirit as extending to all creation is implicitly latent within the Pentecostal theology of the gifts of the Spirit." ${ }^{370}$ What Snell rightly observes — in essence — is a Pentecostal hermeneutical hypocrisy. For Pentecostal exegetes have readily accepted the longer ending of the Markan passage because of its attestation to glossolalia found on the very lips of Christ. Yet, on the other hand, Pentecostals have neglected Mark's call for Christ's disciples to “preach the good news to all creation" (Mark 16:15, italics mine). In the form of this theological correction, Snell creatively offers the theological possibility that verse 17 and 18 of Mark 16 suggest a reversal of the results of transgression in Genesis $1-11 .^{371}$

"As yet, neither Pentecostalism nor the charismatic renewal has produced a consistent theology involving the whole of life," began Dutch Pentecostal pastor/theologian Jean-Jacques Suurmond. ${ }^{372}$ Suurmond's work was the initial substantive full-scale published Pentecostal ecotheological writing in a PNEUMA article in 1988. Suurmond appeals for what he called "a charismatic lifestyle" based on Paul's

\footnotetext{
369 J.T. Snell, "Beyond the Individual and into the World: A Call to Participation in the Larer Purposes of the Spirit on the Basis of Pentecostal Theology," PNEUMA 14.1 (1992), 43-57. For Mouw's original paper which spurred Snell to undertake such a project, see Richard Mouw, "Life in the Spirit in an Unjust World," PNEUMA 9.2 (1987), 109-128.

${ }^{370}$ Snell, "Beyond the Individual and into the World," 49.

${ }^{371}$ Ibid., 50.

${ }^{372}$ Suurmond, “Christ King,” 27, (italics mine).
} 
account of Christ's ascension (Eph. 4:1-16; 1 Cor. 15:28), a lifestyle ultimately realizing "God may be all in all." It is in this "charismatic lifestyle" that we find "a life in harmony, not only with the ecological structure of the whole creation, but even with the inner life of the triune God. ${ }^{, 373}$ Later, Suurmond writes, "here, I think, lies the distinctive contribution of the Pentecostal experience, i.e., its appeal to the churches and the world for an ecological lifestyle. ${ }^{374}$ The mark of the charismatic church is the acknowledgment and incorporation of the diversity of parts in the church as a sign of the idea of the "ecology" of the church. ${ }^{375}$ Broadly, for Suurmond, three elements of this interconnected lifestyle are essential: a personal ecology, an ecclesiological ecology, and a universal ecology. By personal ecology Suurmond suggests the connected life of the trichotomistic person: body, soul, and spirit. Regarding the ecclesiological meaning, he is referring to the interconnectedness of and in the church. And finally, by a universal ecology, he is referring to an experience at harmony with the ecological world. Regarding the care of the world, Suurmond views the Spirit's role in healing this ecological age. He openly admits that, "I do not hesitate to view the increasing ecological awareness as inspired by the Spirit of God." ${ }^{\prime 376}$ At the time of the writing, Suurmond had few if any PCs to engage which is evident in his bibliography. ${ }^{377}$

\footnotetext{
${ }^{373}$ Ibid., 28. For a deeper extrapolation of Suurmond's Charismatic theology, see his later and more developed Suurmond, Word and Spirit at Play.

${ }^{374}$ Suurmond, "Christ King," 27, (italics mine).

${ }^{375}$ Ibid.

${ }^{376}$ Suurmond, "Christ King," 27.

${ }^{377}$ Interestingly, the one single reference to a PC is Walter Hollenweger's text The Pentecostals (1977). Otherwise, no other PC voices are included in his ecological construction.
} 
Perhaps one of the most influential Spirit/creation constructions for PC theology is Clark Pinnock's watershed pneumatological text Flame of Love. ${ }^{378}$ Pinnock's compelling ecumenical pneumatological advance gives a refreshing account of the prevenient Spirit's role in the creational process. ${ }^{379}$ Postpublication has proven it to be one of the more influential (and authoritative) pneumatological texts in the most recent twenty-five years, widely accepted and engaged within and outside PC traditions. ${ }^{380}$ Moreover, it is impossible to dismiss the impact it has had in mainstream Pentecostalism. Perhaps Pinnock's most compelling contribution highlights the creative role of the Spirit at the beginning of Genesis, but not to the demise of the ongoing nature of the creative relationship between the Spirit and creation. ${ }^{381}$ As part of the broader vision of the Spirit's role in the world, chapter 2, "Spirit in Creation," proposes a rich seedbed for charismatic ecotheology, especially an ecotheology formed pneumatologically. ${ }^{382}$

\footnotetext{
${ }^{378}$ Clark Pinnock, Flame of Love: A Theology of the Holy Spirit (Downer's Grove: IVP, 1996).

${ }^{379}$ Ibid. Pentecostals have had somewhat of a love affair with Pinnock and his Flame of Love. Covering ecumenism, pneumatology, the Trinity, creation, soteriology, and a swath of other topics, he has been an increasingly powerful dialogue partner with Pentecostals. On this ongoing dialogue, with a special treatment of Pinnock's Spirit-Christology, see Steven Studebaker, "Integrating Pneumatology and Christology: A Trinitarian Modification of Clark H. Pinnock's Spirit Christology," PNEUMA 28.1 (2006), $5-20$.

${ }^{380}$ For instance, Jürgen Moltmann, Donald Bloesch, the late Stan Grenz, and Carl Braatan, among others, gave overwhelming endorsement of his text. See Macchia's helpful review of Flame of Love, Frank Macchia, "Tradition and the Novum of the Spirit: A Review of Clark Pinnock's Flame of Love," JPT 13 (1998), 31-48.

381 That is to say creatio ex nihilo should never overshadow the creatio continua as it often has in Protestant theology, but must be understood as standing side by side. For further discussion, see, for instance Pinnock, Flame of Love, 51, 61-62. On the issue of Pentecostalism and Pinnock's contention that its greatest contribution may be relationality, see Clark Pinnock, "Divine Relationality: A Pentecostal Contribution to the Doctrine of God," JPT 16 (2000), 3-26.

${ }^{382}$ Pinnock, Flame of Love, 49-77. Although the thrust of his contribution weaves in and out of the Spirit's role in creation, the cornerstone of his pneumatology emerges in chapter 2. Of interest as well is the potential of pneumatology of creation and its ministerial, social, and missiological trajectories. Pinnock's theological agenda has often focused on the Spirit in many areas. For instance, on the Spirit and Pentecostal ecclesiology, see Clark Pinnock, "Church in the Power of the Holy Spirit: The Promise of Pentecostal Ecclesiology," JPT 14.2 (2006), 147-165. For a complimentary example on the intersection of holistic ministry practice based on a pneumatology of creation, see Wonsuk Ma, "The Spirit of God in Creation: Lessons for Christian Mission," TR 24.3 (2007), 222-230.
} 
Pinnock begins by speaking of the "presidency of the Holy Spirit" over the creative process signaled in Genesis 1. Here, God's creative and authoritative powers are matched by a Trinitarian mutuality, overflowing life to the created order. The Spirit is not to be relegated to the status of a third wheel in the creative process, rather as the director and centerpiece. $^{383}$

All of this is offered as part of a broader critique Pinnock offers regarding Protestant theology which often relegates the Spirit's role to Genesis 1 and 2, while forgetting it throughout the remainder of the biblical narrative. This is ultimately suggesting that a responsible pneumatology must perennially reenvision the creation as being continuously renewed as part of the larger creative task of the Spirit upon earth. ${ }^{384}$ By this very nature, therefore, the "Spirit is ecologist par excellence," giving power for its survival and authority for humans to steward the earth-project God initiated. ${ }^{385}$ But the Spirit keeps human freedom intact, for it is the freedom of those who destroy the earth that is protected by the same Spirit. ${ }^{386}$ Simply put, Pinnock's work is monumental for PCs and will garner attention and ongoing scholarly and popular study for years, especially as a contribution to a charismatic understanding of the earth.

\footnotetext{
${ }^{383}$ Pinnock, Flame of Love, 50. Pinnock borrows the Cappadocian idea of the perichoresis in chapter 1 and utilizes it for a continuous theme of love throughout his text. Within this perichoresis, the Trinity is understood within the dance of eternity, dancing through creation. At one point he considers the Holy Spirit as a ballet dancer who dances over creation. Ibid., 70. This is similar to Pinnock's ecclesiology, which at the same time utilizes a charismatic understanding of the church and contends for a social Trinitarian ecclesiology based on the ongoing relationship of the Father, Son, and Spirit.

${ }^{384}$ Pinnock has elsewhere offered striking critiques of Protestantism and Reformed theology. For instance, Pinnock had previously argued that the larger Reformation soteriology is pneumatologically weak as it overemphasizes sin and justification by faith. Frank Macchia, "Pinnock's Pneumatology: A Pentecostal Appreciation," JPT 14.2 (2006), 167-173.

${ }^{385}$ Pinnock, Flame of Love, 76.

${ }^{386}$ Pinnock concludes, "Spirit-shaped ecology does not take away the freedom of those who are threatening it. Though sharing the pain, Spirit does not rescue us from the consequences of our actions." Ibid., 77.
} 
Augustinus Dermawan writes in 2003, "Obviously we may not be able to cure a problem if we do not identify the problem itself." ${ }^{387}$ For Dermawan, who sets off on a more critical tone, Pentecostal ignorance regarding ecological issues has undoubtedly limited their ability to address them. His critical article proposes an interesting ecotheology from an Asian Pentecostal setting. ${ }^{388}$ Dermawan articulates what he believes to be the roots behind the Pentecostal ignorance of ecological concerns in two regards: otherworldliness and pessimism. First, Pentecostals are otherworldly in the sense of being "heaven-focused,"389 or what Russell Spittler considered a "Corinthian spirituality" in his text on Pentecostalism. ${ }^{390}$ No doubt, this strain of expectancy in Pentecostal spirituality is mainstay. But secondly_pessimism — the negative attitudinal sense of its view of "the world," a world nearing an end driven primarily by Pentecostal eschatology. ${ }^{391}$ To reverse this trend in Pentecostal practice and theology, Dermawan emphasizes the need to return to what he called the "Old Testament Spirit Tradition." ${ }^{392}$ This interpretational turn, in line with Wonsuk Ma, recategorizes the OT rûach tradition as a charismatic offering that presents redemptive assistance to the very creation it assisted in creating. ${ }^{393}$ Ecologically speaking, the prophetic tradition seeks to restore justice within the created world. Yet, Dermawan argues, this OT tradition is rarely touched by Pentecostals because "it is not in

\footnotetext{
387 Dermawan, "The Spirit in Creation and Environmental Stewardship," 210.

388 Ibid. Dermawan is a Filipino Pentecostal who has significant influence throughout much of Asia and Asia Minor. Dermawan's initial concern arose from a lecture by colleague Wonsuk Ma criticizing Christian ambivalence and, more notably, Pentecostal ambivalence towards the earth. Ibid., 199.

389 Ibid., 210.

390 Russell Spittler, "Spirituality, Pentecostal and Charismatic," in Dictionary of Pentecostal and Charismatic Movements, ed. S.M. Burgess and M. van der Maas (Grand Rapids: Zondervan, 1988), 804805. Spittler suggests four other characteristics of PC spirituality: experience, orality, spontaneity, and biblical authority.

${ }^{391}$ Ibid., 206.

392 Dermawan, "The Spirit in Creation and Environmental Stewardship," 207.

393 Wonsuk Ma, Until the Spirit Comes: The Spirit of God in the Book of Isaiah. JSOTSup, vol. 271 (Sheffield: Sheffield Academic Press, 1999).
} 
a charismatic category." ${ }^{394}$ Similarly, Christological atonement theories lack a soteriological breadth for "not only humankind but also the whole creation." 395 Dermawan spotlights the Indonesian model of the Ibu Pertiwi as a template for his model. Here, ecological stewardship models must arise out of the relational, the concrete, the intuitive, the mystical, and the aesthetic. ${ }^{396}$ But Dermawan, contextually, enjoys what the West often does not. For it is in the East where the issue of ecological stewardship will prove deeply important because there is a rooted kinship between the natural order and humans.

Edmund Rybarczyk’s irreplaceable 2004 study Beyond Salvation contrasts the theological/spiritual themes in Pentecostal and Orthodox traditions, eventually proposing stimulating insights for PC Spirit/creation theologies. ${ }^{397}$ From a largely historical perspective, Rybarczyk claims that John Wesley's theology, a significant influence on American Pentecostalism, drew heavily on the Eastern fathers, potentially in favor of the East over the West. ${ }^{398}$ Rybarczyk points to one key element giving Pentecostals and the Orthodox theological common ground: their emphasis on the Spirit with a robust pneumatology. Mel Robeck underscores this important point in the introduction to Rybarczyk's text. ${ }^{399}$ Although Western PCs can often wrestle with Eastern mysticism,

\footnotetext{
394 Dermawan, "The Spirit in Creation and Environmental Stewardship," 208, (italics mine). Here Dermawan utilizes the work of Wonsuk Ma in his study on the empowerment motif of God's Spirit (rûach) found in the OT and reconstituted in Luke-Acts. Wonsuk Ma, "The Empowerment of the Spirit of God in Luke-Acts: An Old Testament Perspective," in The Spirit and Spirituality: Essays in Honour of Russell P. Spittler, ed. Wonsuk Ma and Robert Menzies (London: T\&T Clark, 2004), 28-40.

${ }^{395}$ Dermawan, "The Spirit in Creation and Environmental Stewardship," 213.

${ }^{396}$ Ibid., 216.

${ }^{397}$ Edmund Rybarczyk. Beyond Salvation: Eastern Orthodoxy and Classical Pentecostalism on Becoming Like Christ (Carlisle: Paternoster, 2004).

${ }^{398}$ Ibid., 10.

${ }^{399}$ Ibid., xvii.
} 
Rybarczyk proposes a revisited vision of mysticism inherent in both traditions. With this mystical similarity, there remains one element strangely dissimilar between the two. ${ }^{400}$ He suggests the Eastern traditions will often situate the mystical Spirit holistically in creation while PCs emphasize the mystical Spirit individually through the Spirit-infilling of the individual believer. ${ }^{401}$ Both place the mystery in a different locus. Similarly, Pentecostals will tend to view the Genesis narrative themes of imago Dei more on anthropocentric terms relating primarily to Adam and Eve, while Orthodox theology will often view the imago Dei resident throughout the cosmos beyond humanity and more communally than individually. In Rybarczyk's important work we observe an arresting contrast of understanding the Spirit's primary residence of Pentecostals in the individual, and of the Orthodox in the cosmos.

We must also recognize the wide-spanning work of Amos Yong. Yong's groundbreaking The Spirit Poured out on All Flesh (2005) offers fresh insights into a distinctively Pentecostal theology of creation which arises out of his global theology. ${ }^{402}$ Hinging on an Acts 2 pneumatological hermeneutic, Yong's vision covers a number of the pending issues facing contemporary Pentecostalism. This includes the continuing yet evolving struggle between Pentecostalism and the ever-expanding disciplines of the

\footnotetext{
${ }^{400}$ For a helpful text on both mysticism and the interconnectivity of spirituality and theology, see Mark McIntosh, Mystical Theology: The Integrity of Spirituality and Theology, (London: Blackwell, 1998).

${ }^{401}$ Rybarczyk, Beyond Salvation, 9.

402 This is especially the case in terms of pneumatology. Although only a small portion of the chapter is devoted primarily to "environmental issues" in particular, his overall thesis of using the "pneumatological imagination" throughout is exceptional. His sweeping account covers soteriology, Pentecostal history and theology, ecclesiology, science/theology discussions, pneumatology, hermeneutics, and many others. Yong, The Spirit Poured out on All Flesh.
} 
empirical sciences, natural studies, and ecology, among others. ${ }^{403}$ Yong observes

significant adaptations that are taking place in Pentecostal theology. From Pentecostal

Bible Colleges and academies to laity, Yong sees promise in Pentecostals entering, not

only the social sciences, but the natural sciences as well. This shift is quickly changing

the tone of the conversations in both Pentecostal academies and churches. ${ }^{404}$ Now, in

sharp contrast to a previous decade, it is no longer fair to caricature all Pentecostals as

being antiscientific and simplistic in their scientific rationality.

Two theological loci are worth mentioning from Yong's Spirit Poured Out. The

first is a soteriological point. Yong constructs what he calls a "multidimensionality of salvation" similar to the "four-fold" gospel prevalent among early Pentecostals. ${ }^{405}$ Of the seven overarching soteriological perspectives in this soteriological multidimensionality, four are of importance here: namely the material, ${ }^{406}$ social, cosmic, ${ }^{407}$ and eschatological

\footnotetext{
${ }^{403}$ For Yong's science/theology discussion, begin with Amos Yong, "Oneness and the Trinity: The Theological and Ecumenical Implications of Creation Ex Nihilo for an Intra-Pentecostal Dispute," PNEUMA 19.1 (1997), 81-107; Yong, "Rûach, the Primordial Chaos, and the Breath of Life: Emergence Theory and the Creation Narratives in Pneumatological Perspective," in The Work of the Spirit:

Pneumatology and Pentecostalism, ed. Michael Welker (Grand Rapids: Eerdmans, 2006), 183-204; Yong, The Spirit Renews the Face of the Earth; Yong, "The Spirit and Creation: Possibilities and Challenges for a Dialogue between Pentecostal Theology and the Sciences," JEPTA 25 (2005), 82-110. Within, Yong broaches the ongoing and somewhat tepid relationship between theology (esp. Pentecostal) and the empirical sciences, covering new ground on many fronts beyond the often abstract exhortations and oversimplifications commonplace in this conversation. Yong and James K.A. Smith are spearheading Science and the Spirit: Pentecostal Perspectives on the Science/Religion Dialogue, a research initiative funded by the Templeton foundation in 2006-2008. See http://www.calvin.edu/scs/scienceandspirit/, (accessed May 22, 2009).

404 On the shift in papers at the Society for Pentecostal Studies, Yong, The Spirit Poured out on All Flesh, 277. See also Dennis Cheek, Thinking Constructively About Science, Technology, and Society Education (Albany: State University of New York Press, 1992).

${ }^{405}$ These seven include: personal, family, ecclesial, material, social, cosmic, eschatological salvation. Yong, The Spirit Poured out on All Flesh, 97-99.

406 "Materiality of salvation" here is somewhat different from Volf's terminology. Yong seems to mean it more in terms of "materials" for the poor and the needy.

407 That being, "not only the inter-connectedness of human beings and their environment (cf. Acts 2:19-20) but also to the redemption of all creation (perhaps not excluding the fallen principalities, spiritual authorities, and powers; cf. Eph. 6:12)." Yong, The Spirit Poured out on All Flesh, 95.
} 
elements. Here, Yong constructs a more robust soteriology that goes beyond, although importantly includes, what he calls "personal salvation." ${ }^{408}$ No doubt, the ecological schemata are closely tied to this soteriological move. For Yong sees the pending importance of creating a soteriological vision that goes beyond the individual.

Secondly, alongside this enlarged soteriology, Yong frames the ecological discussion anew in a pneumatological context. ${ }^{409}$ Again, this entire Pentecostal pneumatological vision pivots on Acts 2:17-21. ${ }^{410}$ Yong's use of Joel 2/Acts 2 Pentecost narrative as a central point for this framework demonstrates promise and will stimulate scholarship and discussion for years beyond the ecotheological agenda. The language of the Spirit in Joel and Acts is telling. Yong proposes this is seen in the natural elements enlisted of the Spirit of God in the Acts text: "violent wind," "divided tongue," "as of fire," "blood, and fire," and "moon to blood." ${ }^{411}$ Utilizing this linguistic analysis, Yong highlights the theological importance of this natural language. These naturalistic metaphors, used throughout the OT Hebrew narrative solicit something important for Pentecostal ecotheology on two levels. The first is that they create a continuing correlation between the Spirit's presence in creation. The very use of the imagery in the context of the coming of Pentecost speaks volumes of their interconnectivity. But secondly, they show us that the Spirit is "amenable to phenomenological portrayal drawn

\footnotetext{
408 Ibid., 91-92.

${ }^{409}$ What he aptly calls the "pneumatological imagination" throughout his text, as mentioned, is first found in Amos Yong, Spirit-Word-Community: Theological Hermeneutics in Trinitarian Perspective (Burlington: Ashgate, 2002).

410 See Joel 2:28-32. A vision initially described by the prophet Joel concerning "the end times" eventually utilized by the Apostle Peter at Pentecost in Acts 2.

${ }^{411}$ Yong, The Spirit Poured out on All Flesh, 268.
} 
from the experience of the natural world." ${ }^{\prime 412}$ That is, natural metaphors like the ones used here have valuable power to "convey theological pneumatological expression." ${ }^{.413}$ Simply put, natural everyday natural agents have the same power of parable - they point to something deeper and more real. Creation, in this sense, has a pneumatological iconic value to it.

In the same text Yong converses with other important sources to mine a Pentecostal theology of creation. First, Yong suggests there remains a latent theology of creation in the Wesleyan-Holiness tradition that very well could offer an assist to Pentecostal ecotheology. ${ }^{414}$ Some have suggested that the greatest echo in Pentecostal theology of Wesley is his experiential theology. ${ }^{415}$ But is this true ecologically? Beyond his extant readings in science and natural history, Wesley prayed for and had a deep care for the creation. Yong points out that it is believed, at one point during his ministry, Wesley prayed for the healing of his horse. Similarly to his reading of Wesley, Yong extends an interesting discussion on the philosophic framework of Charles Sanders Pierce (1839-1914). Pierce, a promising character for Yong, offers an interesting dialogue partner for pneumatology by virtue of his semiotic/ontological scientific writings.

In these discussions with the scientific community and the biblical narrative, Yong perceives a principle turning in ecological writings. He points out that of his

\footnotetext{
412 Ibid., 269.

413 Ibid.

${ }^{414}$ Ibid., 273-277. For a most recent work on Wesleyan creation theology, see Thomas Jay Oord, ed. Divine Grace and Emerging Creation: Wesleyan Forays in Science and Theology of Creation (Eugene: Pickwick, 2009).

${ }^{415}$ For instance, David Norris makes this case in David Norris, "Creation Revealed," in The Spirit Renews the Face of the Earth ed. Amos Yong (Eugene: Pickwick, 2009), 74-92. Norris argues that along with Calvin, Wesley gave not only room to experience, but was much more "intentional" about giving it room in his own theology and practice. Ibid., 76.
} 
reading, a significant portion of modern ecotheological writings have had to do with the idea of the "Creator Spirit." This "Creator Spirit" is the Spirit of God intimately related to the creation and the continuation of creation. ${ }^{416}$ This theme, Yong solicits, has been extensively developed by scholars in the contemporary biblical, theological, and philosophical communities. It has only been since of late this same connection has been made in Pentecostal scholarship. Frank Macchia likewise forwards an important point about this. In regards to the eschatological Spirit of the Kingdom to come, "Pentecostals have tended to neglect the full breadth and depth of the Spirit's work in all of creation today." ${ }^{417}$ Both Machia and Yong make this central to their theology of creation. Despite having a strong historical pneumatology, the theological connection of Spirit to creation is rather novel for Pentecostalism. In his own way, Yong attempts to correct this. The remaining section of his text is primarily devoted to what he calls a "pneumatological theology of the environment." ${ }^{418}$ In more concrete terms, it is here we see a more developed vision of how Pentecostals can, with a robust pneumatology, better develop creational care by envisioning Acts 2 as a transcending vision that is intended to include all living creatures/beings. Yong concludes, "all flesh, including the wolf and the lamb, the leopard and the kid, the cow and the bear, the lion and the ox, all of whom are included in the blessings of God promised under the covenant with Noah. ${ }^{\prime 19}$

Following Spirit Poured Out, Yong’s 2006 "Rûach, the Primordial Chaos, and the Breath of Life" fanned new life into the theology/science dialogue, suggesting new

\footnotetext{
416 Yong, The Spirit Poured out on All Flesh, 280.

417 Macchia, "Tradition and the Novum of the Spirit," 38.

418 Yong, The Spirit Poured out on All Flesh, 299-302.

419 Ibid., 300. Here he refers to the Noamic covenant in Genesis 9:8-17.
} 
possibilities between a theology of the Spirit with an engagement of emergence theory, particularly that of Philip Clayton. ${ }^{420}$ Utilizing Clayton's emergence theory, Yong contends there remains a central connection between biblical creation narratives and scientific comprehensions of natural history. Emergence theory is important in this regard. ${ }^{421}$ In particular, it is in the Genesis Yahwist/Priestly accounts of creation that we find promising material for emerging pneumatology of creation. Ensuing his examination of emergence theory, and an overview of rûach terminology in the creation narratives, Yong proposes three routes a pneumatological theology of creation can contribute to emergence theory and science. First, it will bring "philosophical theory and biblical text together in mutually beneficial ways." ${ }^{\text {422 }}$ Second, pneumatology helps to "fill out the theological content of Clayton's emergence theory." ${ }^{423}$ And thirdly, creational pneumatology "provides some relief to the strain imposed by the acknowledged theological dualism in Clayton's emergence theory. ${ }^{, 424}$ Eventually, Yong's overall vision is that of a scientific/theological dialogue that is mutually edified and transcends modern Western dualism so prevalent in contemporary comprehensions. For Yong, this is a conversation that would ultimately benefit PCs greatly.

\footnotetext{
${ }^{420}$ Yong, "Rûach, the Primordial Chaos, and the Breath of Life." Earlier, Yong points out that there are sixteen ways in which science and religion use the word "Spirit". Yong, Discerning the Spirit(s), chap. 1. For Clayton's seminal work on the topic of emergence theory, see his Philip Clayton, Mind \& Emergence: From Quantum to Consciousness (Oxford: Oxford University Press, 2004).

${ }^{421}$ Yong admits there is a complexity to emergence theory but offers an analysis of the overall field for his readers. Yong calls these perpetual rereadings of the creation accounts for pneumatological constructions the "canonical-Pneumatological perspective." He further lists the eight characteristics of emergence theory, Yong, "Rûach, the Primordial Chaos, and the Breath of Life," 184-188.

422 Ibid., 201.

${ }^{423}$ Ibid.

${ }^{424}$ Ibid.
} 
Finally, we turn to Yong's disability theology, which has further heightened Pentecostal pneumatology to fresh and new areas of dialogue. His Theology and Down Syndrome (2007) lays out a thoroughly gripping and personal account of disability theology from an Acts 2/pneumatological hermeneutic. ${ }^{425}$ Following an examination of the biblical and historical witnesses to disability in part I, and a multifaceted overview of various fields with whom he will converse in part II, Yong suggests a new theological agenda for understanding both disabled persons and an reinvigorated comprehensions of imago Dei. In response to Yong's disability theology, Jeff Hittenberger and Martin Mittelstadt contend that this novel approach offers Pentecostalism "an invitation to an enlarged theology of healing." ${ }^{426}$ And it has led others to embrace such a conversation, as Yong is not the only Pentecostal to engage this field. For instance, Steven Fettke's very personal and gripping account of his own son's disability employs pneumatological thinking for a better understanding of God's role in his son's life. Fettke asks, "Does the Spirit 'hover' over my autistic son in his conception and birth?" ${ }^{427}$ His work, as well, is exemplar of many accounts taking place, which seek to better understand the Spirit's role

\footnotetext{
425 Yong, Theology and Down Syndrome. This work, a theological and pneumatological sketch of the overarching disability theology field in conversation with his "pneumatological imagination," comes as a very personal approach by Yong, who has a brother with Down syndrome.

426 Jeff Hittenberger and Martin Mittelstadt, "Power and Powerlessness in Pentecostal Theology: A Review Essay on Amos Yong's Theology and Down Syndrome: Reimagining Disability in Late Modernity," PNEUMA 30 (2008), 137-145 (142).

427 Steven Fettke, "The Spirit of God Hovered over the Waters: Creation, the Local Church, and the Mentally and Physically Challenged, a Call to Spirit-Led Ministry," in 37th Annual Meeting of the Society for Pentecostal Studies (Duke University, Raleigh-Durham, NC: 2008), 5.
} 
in aspects of creation that lack, from the perspective of the intellectual, rationalistic perfection. ${ }^{428}$

Lyle Dabney, drawing on his RC background, contributes to a PC theology of nature with a piece focusing on what he calls the "possibility of God" in relation to the created order. ${ }^{429}$ Dabney's overarching thesis, hinging exegetically on the earliest creational narratives in Genesis, suggests a central theme pertaining to God's relation to the cosmos. This theme is of a creation and "new creation" coming not only through the Word (Christology), but also through the Spirit (Pneumatology). Creation, as the socalled realm of the Spirit, is imagined as the realm of possibility where God freely creates. Dabney suggests, therefore, that in the end creation is not one of what he calls "creaturely necessity," but of "divine possibility," where God creates through his Spirit out of love and not requirement. ${ }^{430}$ For Dabney, nature becomes, in essence, the future and possibility of God's createability in the cosmos mirroring the very nature of God's character (Rom. 1:18-23). Previously, Dabney's focused on the pneumatologia crucis, or the suffering Spirit of God in connection with Christ on the cross. ${ }^{431}$ Here, the Spirit

\footnotetext{
${ }^{428}$ Fettke rightly comments, "If our pneumatology can begin with conception and birth, then those who are not high on the hierarchy of giftedness or significance in the way normally understood can be appreciated for the way God has created them and given them their unique "life force." Ibid., 4.

${ }^{429}$ Lyle Dabney, "The Nature of the Spirit: Creation as a Premonition of God," in Work of the Spirit, ed. Michael Welker (Grand Rapids: Eerdmans, 2006), 71-86 (72). See also his pneumatological analysis and formation in Lyle Dabney, "Otherwise Engaged in the Spirit: A First Theology for a Twenty-First Century," in Future of Theology, eds. Miroslav Volf, Carmen Krieg, and Thomas Kucharz (Grand Rapids: Eerdmans, 1996), 154-163. Dabney was raised in the Assemblies of God movement and is now in the United Methodist tradition.

${ }^{430}$ Dabney, "The Nature of the Spirit," 73.

${ }^{431}$ Lyle Dabney, "Naming the Spirit: Towards a Pneumatology of the Cross," in Starting with the Spirit, eds. Stephen Pickard and Gordon Preece (Hindmarsh, 2001), 28-59. In this interesting piece, Dabney utilizes the Spirit as the touch-point of the cross, where God encounters the pain of salvation. Mirroring Moltmann's "kenotic" theology of God on the cross flowing from his social Trinity, Dabney utilizes strikingly similar language of a "kenotic" theology of the Spirit in the suffering of God on the Spirit and in creation. Moltmann no doubt has shown his reliance in social Trinitarianism by writing no less than five
} 
participates in the cosmic creation of the world and likewise coredeems with Christ by suffering with the crucified one. Although no longer a Pentecostal, Dabney's contribution is crucial for one reason: it proposes a prime example of non-Pentecostals entering into formal academic conversation with Pentecostals (interestingly) in a text devoted to Pentecostalism. ${ }^{432}$ While Dabney's bifurcation of the Spirit and Word in the creation account of Genesis is questionable, given the importance of a Trinitarian cohesiveness, Dabney's work creates points of contact with Pentecostal ecotheology that are pregnant with possibility. ${ }^{433}$

Andrew Gabriel's fascinating work published in JPT has examined the interconnected nature of the Holy Spirit to technology. ${ }^{434}$ Within, Gabriel covers two areas concerned with the human/ecological material relationship and resultant pneumatological implications. First, he posits that pneumatology has tremendous affects on both environmental ethics and the shaping of technological development and usage. Yet, on the other hand, his pneumatological approach explores how technological use

books on the subject. For an overview of this, see Amos Yong, "A Theology of the Third Article?: Hegel and the Contemporary Enterprise in Fist Philosophy and First Theology," in Semper Reformandum: Studies in Honour of Clark H. Pinnock, eds. Stanley Porter and Anthony Cross (Carlisle: Paternoster, 2003), 208301.

${ }^{432}$ At the same time Pentecostals have increasingly found theological fuel outside their own tradition in this pneumatology of creation. For instance, see the ecumenical Veli-Matti Kärkkäinen, "The Working of the Spirit of God in Creation and in the People of God: The Pneumatology of Wolfhart Pannenberg," PNEUMA 26.1 (2004), 17-35.

${ }^{433}$ For example, Dabney moves away from literalistic interpretations of the Genesis account, commenting that the Genesis account is much less pertaining to the "how" of creation but centers on the "whom" in creation. In doing so, he places the central role of creative narrative not on the mechanical beginning of the world but as the heart and personality of creation. That is, he goes beyond an overly simplistic mechanical explanation of the creation to the more emotive and heartfelt purposes beyond creation. Dabney, "The Nature of the Spirit," 74.

${ }^{434}$ Andrew Gabriel, "Pneumatological Perspectives for a Theology of Nature: The Holy Spirit in Relation to Ecology and Technology," JPT 15.2 (2007), 195-212. Gabriel has published works conversant both with RC theology and Moltmann's kenotic and Trinitarian theology. For instance, see his Andrew Gabriel, "Beyond the Cross: Moltmann's Crucified God, Rahner's Rule, and Pneumatological Implications for a Trinitarian Doctrine of God," DA 19.1 (2008), 93-111. 
transforms nature, all the way "from the genes inside of us to the forests around us." Relationally, Gabriel concludes that the Spirit produces a sort of "Kinship through the Spirit." 436 Similarly, he touches on a conceptual panentheism emphasizing the "wounded spirit" not only suffering with creation, but also having a perfecting nature in eschatological terms. ${ }^{437}$ Hence, through the Spirit's incarnation, "human intervention in nature by the means of various technologies might be permitted." ${ }^{238}$ This continued theme of the Spirit's work beyond the church and soul-salvation envisions "the whole of the cosmos."439

Steven Studebaker's 2008 contribution uniquely offers a critical analysis of what he sees as a Pentecostal/Evangelical theological marriage to common/special grace and revelation. ${ }^{440}$ Wherefore Pentecostals exercise continuity and discontinuity in many ways within global Evangelicalism, it is on this one connection, above others, that is a "foundation for environmental neglect in Pentecostal theology." "441 The danger, writes Studebaker, with extrinsic soteriological models of a theology of creation is a built-in separation of creation from its salvation and redemption by the same Spirit into almost "sacred/secular" categories. ${ }^{442}$ What he proposes is a return to a "unified theology of grace" resulting in "the unity of the Spirit's work in creation and redemption," which

\footnotetext{
435 Gabriel, "Pneumatological Perspectives for a Theology of Nature," 196.

436 Ibid.

437 Ibid., 200-205.

438 Ibid., 212.

439 Ibid., 198.

440 Steven Studebaker, "The Spirit in Creation: A Unified Theology of Grace and Creation Care," ZY 43.4 (2008), 943-960. For another examination of Studebaker's pneumatology with an examination of his overall soteriology, see Steven Studebaker, "Pentecostal Soteriology and Pneumatology," JPT 11.2 (2003), 248-270.

441 Studebaker, "The Spirit in Creation," 943, (italics mine).

442 Ibid., 948.
} 
goes beyond extrinsic/intrinsic models of salvation and redemption. ${ }^{443}$ Eventually, such a theological correction will help to overcome intrinsic models of the hierarchical modalities of the Spirit's presence throughout creation in its redemption, not just its creation — an arena neglected by both Evangelicals and Pentecostals. ${ }^{444}$ Although Studebaker seems aware this critique will be challenging to swallow for a Pentecostalism having readily being built on a pneumatological comprehension of the Spirit as one whom, at some level, has a differing stance both towards the believer/unbeliever, but also towards nonhuman/human creation. Therefore, it is not surprising that these extrinsic understandings of the Spirit of God would lead to a hierarchical view of creation, with humans at the top, and Christian humans above them within Pentecostal spirituality and theology.

Pentecostals continue to display a keen ability to catalyze dialogue with those outside their own traditions. This is exemplified in Pentecostal Peter Althouse's 2009 ongoing theological exegesis of Jürgen Moltmann's theology of the "theology of divine kenosis in which the descent of the Spirit as the presence of God in creation becomes vulnerable in the suffering of the world. ${ }^{445}$ Drawing on Moltmann, the Spirit becomes vulnerable to suffering in creation. This kenotic pneumatology, spoken of by Moltmann, is God's encounter with creation by means of his omnipresence both in the Trinity and

\footnotetext{
${ }^{443}$ Ibid., 949. He earlier makes the case that this creation care is a "pneumatological participation in the eschaton because the scope of redemption extends to all creation, and the Holy Spirit is the intrinsic divine presence that leads all of creation to its redemptive consummation." Ibid., 954, (italics mine).

${ }^{444}$ Studebaker concludes, "few Evangelicals and Pentecostal Christians consider creation care as an arena of the Spirit's work." Ibid., 953.

${ }^{445}$ Peter Althouse, "Implications of the Kenosis of the Spirit for a Creational Eschatology," in The Spirit Renews the Face of the Earth, ed. Amos Yong (Eugene: Pickwick, 2009), 155-172 (155). Althouse has done significant work engaging the overall thought, and most notably, the eschatology of Jürgen Moltmann. For example, see Peter Althouse, Spirit of the Last Days: Pentecostal Eschatology in Conversation with Jürgen Moltmann, JPTSup, vol. 25 (London: T\&T Clark, 2003).
} 
the greater universe. While affirming the kenosis of Christ in the cross, as with Dabney, Althouse contends that the ongoing kenosis of the Spirit in the suffering of the cosmos offers another interesting potential in Pentecostal pneumatology. Drawing on Moltmann again, the Spirit's experience of the earth is paralleled by the innerrelational connectedness of the Trinity by the creative act of the Father, through the Son, and filled with the Spirit in a sort of social Trinitarianism of all creation. It is, therefore, in this "panentheistic" vision that "God opens himself up to creation." 446 Creation and cross become the two "modes of divine kenosis." ${ }^{447}$ And as the Spirit's kenosis is discovered throughout all creation, Althouse points out that even Moltmann's own pneumatology creates a sense of the charismatic element of the Spirit. ${ }^{448}$

\subsubsection{Pentecostal Ecotheologies}

Finally, we turn to a number of ecotheological themes that fall outside Charismatic social justice and Spirit/creation theologies: distinctive Pentecostal ecological approaches. Here we will explore a scattering of various explorations into the topic from a distinctively Pentecostal viewpoint. We begin with Harold Hunter's introduction for Pentecostalism to the broader issues related to the ecological crisis nearly twelve years after Suurmond's article in $2000{ }^{449}$ Hunter's work focuses primarily on the healing aspects of ecotheology. Utilizing Harvey Cox's technological theory, Hunter contends that human vocation has become less to do about vocation/work and more with technological power behind the

\footnotetext{
446 Althouse, "Implications of the Kenosis of the Spirit for a Creational Eschatology," 158.

447 Ibid., 166.

448 Ibid., 170.

449 Harold Hunter, "Pentecostal Healing for God's Sick Creation?," SC 2.2 (2000), 145-167.
} 
work. ${ }^{450}$ That is, the modern workplace emphasizes efficiency, technological escalation, and production value - not the work itself. This has, in turn, led to a loss of experience of God's creation. In this light, Hunter asks how Pentecostals have previously engaged creation? He notes a number of prayer services, church events, and important advancements in Korea where creation is centered in praxis and piety. ${ }^{451}$ But as a whole, for Pentecostals, ecological care is a nonissue. He comments that while many Pentecostals repudiate the right to smoke, those who condemn smoking "find themselves passively taking in many of the same chemicals and seem less concerned about enough air for future generations to breath. ${ }^{, 452}$ Utilizing a Pentecostal healing motif, Hunter asks why it cannot be extended creationally—for a sick creation makes us all ill. ${ }^{453}$ Serving more as a rhetorical piece, it is difficult to discern a theological development other than connecting the Pentecostal "healing motif" to a healing of the earth. At the time, Hunter's piece broke new ground for many Pentecostals, and therein lies its strength. In total, Hunter's work serves best as an opening page than a substantive chapter for Pentecostal ecotheology.

Jared Boone reminds us that healing, even ecological healing, requires covenant. ${ }^{454}$ Contending for the care of creation covenantally on the basis of Israel's

\footnotetext{
${ }^{450}$ For example, in a footnote Hunter writes that "human work seems increasingly dissociated from creation." Hunter, "Pentecostal Healing for God's Sick Creation?," 149. For Cox's work that is the conversation piece for Hunter in the text, see Cox, The Secular City.

${ }^{451}$ Hunter, "Pentecostal Healing for God's Sick Creation?," 150.

452 Ibid., 153. Simon Chan, in looking at Pentecostal spirituality, has argued that focusing on the evil nature of smoking and drinking "externalizes sin" and can often tempt us to forget larger societal ills that stem from the depravity of the human personhood. Simon Chan, Spiritual Theology: A Systematic Study of the Christian Life (Downer's Grove: IVP, 1998), 83.

${ }^{453}$ Hunter, "Pentecostal Healing for God's Sick Creation?," 154.

454 Jared Boone, "Created for Shalom: Human Agency and Responsibilty in the World," in The Spirit Renews the Face of the Earth, ed. Amos Yong (Eugene: Pickwick, 2009), 17-29.
} 
responsibility to protect shalom, or peace of the land, Boone argues that "the care of creation should be motivated by both love for God and love for the neighbor." $" 455$ This is reflected in two ways: first, love for God and God's creation. But secondly, a realization of love for all living neighbors and the wellbeing of all humanity based on the motif of shalom. Through his utilizing the Hebrew concept of shalom as the central task of humanity, Boone suggests that human beings are to be "caretakers" of the earth to usher in this shalom/peace of God. ${ }^{456}$ Boone's examination raises many historical/theological themes in Israel's story of ushering in this shalom: land-laws, Sabbath-keeping, Jubilee. In a sense, therefore, Jesus, and Pentecost by extension, is the recapitulation of these "shalom" themes of the Hebrews. Such historical/theological studies as Jared Boone's typify a growing understanding within the Pentecostal tradition of the long-withstanding tradition of ecojustice preceding Pentecost.

Finally, we encounter an approach to ecotheology through the lens of the Pentecostal theme of "full-gospel" as discussed by Matthew Tallman and Shane Clifton. Originally presented at the SPS yearly gathering in 2008, Tallman continues this exploration of a Pentecostal ecotheology in his article on Pentecostal ecology. ${ }^{457}$ Tallman's article utilizes the "four-fold" gospel articulated by Donald Dayton as a framework for a Pentecostal ecological ethic. ${ }^{458}$ Although showing some reservation about the positives and negatives of using such "four-fold" framework, Tallman articulates some interesting proposals. Of significance, he, as will we, engages the

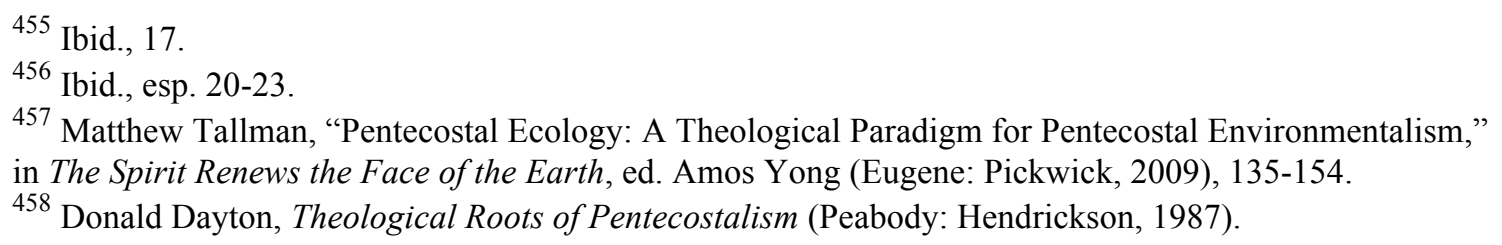


ecopneumatological works of Mark Wallace, giving special attention to renewal of pneumatology in the ecumenical church. ${ }^{459}$ Through a reinvigorated view of the Spirit outside of Pentecostalism, such as WCC and RC, argues Tallman, Pentecostals can enter the conversation on such a wave of pneumatological excitement. Because of the cosmic Spirit, it is in the Spirit that God experiences the pain of creation. ${ }^{460}$ But this essence of God's pain, Tallman points out, does not always sit well with Pentecostals. He argues that "Pentecostal triumphalism" ignores the suffering aspect of Christ and the Spirit in favor of such atonement theories as Christus Victor. ${ }^{461}$ Thus, such theologies that emphasize the pain of God often go by the wayside in Pentecostal theology. As well, Tallman's examination of the historical healing motif within Pentecostalism is stimulating. ${ }^{462}$ Citing early pre-Pentecostal progenitors such as Johann Blumhardt, ${ }^{463}$ John Wesley, Charles Cullis, and F.F. Bosworth, Tallman envisions a contemporary trajectory rooted historically in early Pentecostal views of natural healing. Tallman points out that of the 3,077 articles on ecotheology and faith listed by the American Theological Library Association, there are no more than ten at the point of this publication devoted to a PC view of ecotheology. ${ }^{464}$ Similarly, he is critical of anthropocentric approaches stressing hierarchical cosmology while utilizing such theologians as Sallie McFague and Thomas Berry to express his criticism. But in the end, Tallman argues that the foundation

\footnotetext{
${ }^{459}$ Tallman here cites his exploration into the works of Wallace. Mark Wallace, Fragments of the Spirit: Nature, Violence, and the Renewal of Creation (New York: Continuum, 1996).

${ }^{460}$ Tallman here utilizes the thought of Jürgen Moltmann's creational theology and theology of pain.

${ }^{461}$ Dabney, "Naming the Spirit," 139.

462 Tallman, "Pentecostal Ecology," 142-145.

${ }^{463}$ This is in the same line as Frank Macchia's work on the Pietist movement. Macchia, Spirituality and Social Liberation.

${ }^{464}$ Thanks to Tallman for this observation. Sadly, he does not list them in his text. Tallman, "Pentecostal Ecology," 136-137.
} 
of Pentecostal theology, the "four-fold" gospel, is a great starting place for Pentecostal ecotheology. In Pentecostal history there lays a promise of potential in a view of the holistic gospel. For if Pentecostals could more willingly embrace this on an ecological scale, maybe they would find, in the words of Tallman, that "perhaps Pentecostals have already been ecologists, they just didn’t know it." ${ }^{465}$

\section{Similar to Tallman is Australian Assemblies of God scholar Shane Clifton's} creative approach. ${ }^{466}$ Clifton criticizes an impotent and undeveloped "full-gospel" vision as the ecological curse of Pentecostal movements. Clifton's critique, while focusing on Pentecostalism, argues that Christianity at large is guilty for the creational demise by way of its "otherworldly" concern, echoing such voices as sociologist Margaret Poloma and theologian Harvey Cox ${ }^{467} \mathrm{He}$ argues, along with others, that this drive comes from a predominately fundamentalist impulse and narrow eschatological vision. ${ }^{468}$ To illustrate, he appraises his own experience within the Australian Assemblies of God as his focal point where he has encountered opposition to his environmental questions. On a doctrinal level, Clifton suggests that observing young earth creationism and literalistic views of creation (readily opposed to creation care) do not necessarily need to be core elements of Pentecostal doctrine. He points to the fact that in the Australian Assemblies of God,

\footnotetext{
465 Ibid., 152.

466 This "full gospel" was original to the Holiness tradition and borrowed by the earliest Pentecostals on five theological levels: (1) Justification by faith, (2) Sanctification by faith as second work, (3) Healing of the body through the atonement, (4) Premillenial return of Christ, (5) Baptism followed by glossolalia. Land, Pentecostal Spirituality, 18. Clifton does not make the case that the "four-fold" gospel should be abandoned. Rather they should be expanded, to include ecological dimensions. For instance, Jesus as Savior should go beyond the salvation of the soul to include the salvation of the soil.

${ }^{467}$ Clifton, "Preaching the 'Full Gospel' in the Context of the Global Environment Crises," 118.

${ }^{468}$ Vinson Synan, "Fundamentalism," in Dictionary of Pentecostal and Charismatic Movements, eds. S.M. Burgess and M. van der Maas (Grand Rapids: Zondervan, 2002), 324-327.
} 
young earth creationism was not adopted until $1992 .{ }^{469}$ These awry hermeneutics matched by Western philosophic imperialism have, for Clifton, alienated most Pentecostals from ecological care. Drawing from John Douglas Hall, he argues that hierarchical views of human predominance in the creational sphere, often misconstrued in the doctrine of imago Dei, have left Pentecostals stranded. He sees eventual promise in a return to a pneumatological theology of creation. ${ }^{470}$ This push will be forced to overcome, what he calls "fundamentalist conceptions of creation, salvation, and eschatology, and materialist understandings of prosperity...[which] can no longer be called a 'full gospel." ${ }^{4711}$ Clifton's argument of an impotent "four-fold" gospel deserves attention. If this Pentecostal message is "full" as it is often preached, would it not make sense to include elements of this gospel that capsulate the remainder of God's creation. Where Clifton's argument is strong is in his critical examination of historical structures within Pentecostal movements for the purposes of environmental concerns.

\subsection{Summary}

Three trajectories have been examined to draw from for a Pentecostal theology of ecology: social justice theologies, Spirit/creation theologies, and distinctive Pentecostal ecotheologies. What might we learn from this analysis and how might they be critiqued?

First, let us reflect on the Charismatic social justice theologies. With all of the attention Pentecostal movements have received regarding its growth, mobility, and

\footnotetext{
${ }^{469}$ Clifton, "Preaching the 'Full Gospel' in the Context of the Global Environment Crises," 120-121.

${ }^{470}$ Ibid., 126.

${ }^{471}$ Ibid., 49.
} 
cultural integration, some needed attention has been given by the works listed to the relationship between their theology and social justice practice in a global setting. ${ }^{472}$ This is true on a sociological level as well. For example, Poewe's Charismatic Christianity as a Global Culture informs us how seemingly otherworldly PC Christians exist sociologically in "the world" today. ${ }^{473}$ As well, sociologist Margaret Poloma's sociological look at the Assemblies of God gives attention to a historical Pentecostal denomination proffering us an unfettered inside look at denominational function and the role it plays in Pentecostal wax and wane. ${ }^{474}$ But the relationship between social justice theology to Pentecostalism remains at some points, evocative. This may be for a number of reasons. It is somewhat convincing that the Holiness movement's early rejection of the social gospel movement launched by Washington Gladden (Congregationalist) and Walter Rauschenbusch (Baptist) in the mid-nineteenth century set in motion a suspicion towards such social justice endeavors by Holiness/Pentecostal believers. ${ }^{475}$ It would be likely this affected at least some in early Pentecostalism. Peculiarly enough, even the very lower class individuals who would have benefited the most from social theologies in the earliest Pentecostal churches shunned these works as "negative" and worldly along

\footnotetext{
${ }^{472}$ For instance, academically, many Pentecostal study centers, Bible Colleges, Graduate, and PhD programs have played an increased role in this regard. For a helpful and often engaged study of Pentecostal pedagogy and scholastic vision see Cheryl Bridges Johns, Pentecostal Formation: A Pedagogy among the Oppressed, JPTSup, vol. 2 (Sheffield: Sheffield Academic Press, 1993).

${ }^{473}$ Karla Poewe, Charismatic Christianity as a Global Culture (Columbia: University of South Carolina Press, 1994).

${ }^{474}$ Margaret Poloma, The Assemblies of God at the Crossroads. Broadly, such sociological resources have grown in number. For other examples, see David Martin, Pentecostalism: The World Their Parish, Religion and Modernity (Oxford: Blackwell, 2002); Grant Wacker, Heaven Below: Early Pentecostals and American Culture (Cambridge: Harvard University Press, 2003).

${ }^{475}$ Walter Rauschenbusch, Christianity and the Social Crisis in the 21st Century: The Classic That Woke up the Church, (San Francisco: HarperSanFrancisco, 2007).
} 
with the remainder of society. ${ }^{476}$ But surprisingly, the work that we have encountered here seems to illustrate a reversing of this trend, exhibiting greater openness to social theologies. We observed, in Christenson's charismatic social theology, Villafañe and Sepulveda liberationist theologies, Volf's vocational theology, and Dempster's eschatological social theology, a quiet social justice theology in PC spirituality that seemingly has endless potential to be an ecologically-centered theology with possibilities for strident social action.

It is important for us to note that our examination thus far has shown the Charismatic movement having been quite accommodating to Pentecostalism in bringing strains of social justice theology from the heart of these more historic Christian traditions (e.g. Lutheranism). We saw that Christenson's theological social justice had a greater impact in initiating Pentecostal ecotheology perhaps more than any other, at least in the earliest formation of Pentecostal ecotheology. I would argue that Pentecostalism gave to the Charismatic movement their theology of the Spirit while the Charismatic movements gave to Pentecostalism social theologies, ecclesiologies, and theological traditions. It has been a dialectical relationship. But this dialectical influence of PC theology has been seen elsewhere. We observed this in the connection between Pentecostal spirituality and liberation theology in places like Chile, exemplify a soteriological practice that more readily focuses on contemporary social issues rather than overly emphasizing apocalyptic eschatology. Dempster showed us that Pentecostal eschatological fervor does offer a model for social justice practice in light of eschatology. Dempster's work has proven a

\footnotetext{
${ }^{476}$ Synan, The Holiness-Pentecostal Tradition: Charismatic Movements in the Twentieth Century, 47. Rauschenbusch's social theology attempted to see organize culture around gospel social precepts as a strong derivative of Albrecht Ritschl's theology (1822-1889).
} 
champion in PC circles for liberative causes of social justice, ethical philosophy, and theological ethics. ${ }^{477}$

A strength of the literature we examined exhibited a powerful connection between Spirit baptism and the larger motif of social justice. In some of the other readings we encountered (e.g. Volf), this continues to offer an insightful possibility to pneumatologically centered forms of praxis. Furthermore, this creative connection between the healing power of Spirit baptism in the believer and in the broader world establishes a novel way of thinking about ordo salutis. In this new context, Spirit baptism is inherently social, political, and even ecological. To be baptized in the Spirit is to be anointed to usher in God's Kingdom everywhere. Dempster demonstrates that the liberative power of Spirit baptism, and his work continues to be a substantive dialogue partner as well as a promising expression in the formation of Pentecostal ecotheology conscience. ${ }^{478}$ Miroslav Volf's reflective analysis of the relationship between Pentecostal and liberation theologies rightly sees a strain of spirituality they both share: healing. But Volf argues that Pentecostals have a great theology of healing but tend to be rather selective about its breadth. Healing is viewed, in Pentecostal practice, in anthropocentric

\footnotetext{
${ }^{477}$ For a list of the extensive works of Murray Dempster on this and many other topics related to emerging Pentecostal ecotheology, see Murray Dempster, "Evangelism, Social Concern, and the Kingdom of God," in Called \& Empowered: Global Mission in Pentecostal Perspective, eds. Murray Dempster, Byron Klaus, and Douglas Petersen (Peabody: Hendrickson, 1991), 22-43; Dempster, "Christian Social Concern in Pentecostal Perspective."; Murray Dempster, "Church Mission and Social Concern: The Changing Global Face of Classical Pentecostalism," TR 11 (1994), 1-32; Murray Dempster, "A Pentecostal Approach to Evangelization and Social Concern," TR 16 (1999), 41-66; Murray Dempster, "Social Concern in the Context of Jesus' Kingdom, Mission, and Ministry," TR 16 (1999), 43-53; Murray Dempster, "Pacifism in Pentecostalism: The Case of the Assemblies of God," in Fragmentation of the Church and Its Unity in Peacemaking, eds. Jeffrey Gros and John Rempel (Grand Rapids: Eerdmans, 2001), 137-165; Murray Dempster, Byron Klaus, and Douglas Petersen, eds., Called \& Empowered: Global Mission in Pentecostal Perspective (Peabody: Hendrickson, 1991).

${ }^{478}$ For instance, see Clifton's utilization of Dempster's work throughout Shane Clifton, "Preaching the 'Full Gospel' in the Context of the Global Environment Crises."
} 
terms rather than cosmic terms. Both liberation theology and Pentecostal theology give significant credence to the salvific/healing in soteriology. This broadly reflects the broader NT teaching on salvation where personal, physical, and financial healing are requisite elements of Christ's salvation here and now.

Let us turn now to the Spirit/creation theologies. We encountered some fascinating pieces. For instance, we examined the renewed pneumatological relationship to the disabled (Yong), renewed relationship to creation (Studebaker), renewed relationship to politics (Hollenweger), and the poor, oppressed, and suffering (Dabney). Hollenweger, as a student of classic Pentecostalism, offered that a charismatic theology based on Pauline literature is a model for both the ecumenical church as well as an comprehension of the larger world — the body of God. I agree with Hollenweger that pneumatology has largely been relegated to Christology (Spirit-Christology) and soteriology (Spirit-salvation). His call to a return to a truly pneumatological view of all things will be vital to a Pentecostal ecology. It is this retrieval of the "Creator Spiritus ... a perplexing 'lost' entity for the West," where we can expand a more holistic pneumatology. ${ }^{479}$ It appears, in a very primitive sense, that Hollenweger's proposal of a pneumatological-centered model made way for the Spirit even in the organic life of creation. ${ }^{480}$ And only when PCs return to a posture of sensitivity found in this understanding of the Spirit "as the giver of life," only then can we discernibly "recognize the Spirit in unusual places and in unexpected people, in all creatures great and small,

\footnotetext{
${ }^{479}$ Hollenweger, "All Creatures Great and Small," 44.

480 David Martin and Peter Mullen, Strange Gifts?: A Guide to Charismatic Renewal (Oxford: Blackwell, 1984), 7.
} 
we might win new friends." ${ }^{481}$ Therefore, a return to an understanding of the Spirit in all creatures great and small gives Spirit-centered expression room for creative and innovative pneumatology in PC traditions. This is seen as well in the endeavors of Amos Yong. Yong suggests in his pneumatological writings that the Spirit is deeply connected "ontologically and epistemologically" to the created order is both founded and a thoughtful corrective. ${ }^{482}$ As mentioned in Yong's reflections on the language of the Pentecost narrative, we find amongst the biblical narrative a continuous connection between language of the Spirit and created entities such as water, birds, and wind. This connection should play a key place of discussion for creation care.

We have discovered that the Spirit does not simply relate to the creation creatively but eschatologically as well. ${ }^{483}$ The Spirit comes and will make all things new. That is, the Spirit must be integrated both as Creator Spirit and an agent in creatio continua, the continuous ongoing creational process for the birth of the new heavens and new earth. ${ }^{484}$ Eschatologically speaking, the Spirit prepares creation for this newness. Yong, in this eschatological setting, contends that this Spirit/creation motif leads all to "concrete" ways in which we are called to accommodate this redemption process. ${ }^{485}$ Almost in response to Hollenweger, I would suggest the weakness therefore of the Spirit/creation approach is that it could often lack a Christological element that appropriately brings together the work of the Christ and the Spirit-outpouring of

\footnotetext{
${ }^{481}$ Hollenweger, "All Creatures Great and Small," 53, (italics mine).

${ }^{482}$ Yong, The Spirit Poured out on All Flesh, 300.

${ }^{483}$ Ibid., 301.

484 Theologians have spoken of the "conditional immortality" of the human personhood after death suggesting it requires God's continuous/ongoing love and sustaining power to keep everything in existence. Creatio Continua is, in essence, "conditional mortality," God's all pervasive power in sustaining life before death.

${ }^{485}$ Yong, The Spirit Poured out on All Flesh, 301.
} 
Pentecost (Soteriological Pneumatology). That is, we cannot imagine the embodiment of the Spirit in creation unless we do so in the context of the creative love of the Word (Christ).

But the strength of the Spirit/creation theology is largely its relationality. William Brown's Ethos of the Cosmos (1999) offers Pentecostalism (and Christian theology in general) a significant challenge to both recapture the story of creation and live an ethic informed by it. ${ }^{486}$ Brown makes the case that our ecological ethics and morality will simply be an overflow of nothing more than our cosmological vision? ${ }^{487}$ That is, our practice is entirely interrelated to our story of creation. Spirit/creation theology in PC theology is such an attempt at a renewed cosmological vision. It is, in the words of Walter Brueggemann, an attempt to "fund counter-imagination," or create a new kind of imagination in Pentecostal theology. ${ }^{488}$ For the authors we have engaged, the story of the earth is one where the Spirit indwells charismatically, giving life, bringing death, and sustaining it at every corner. Pentecostal cosmology in this way is their pneumatology. While some may caricature Pentecostals has having a, in the words of John Haugh, "cosmic homelessness," we might see cosmological insurgency when formed in said

\footnotetext{
${ }^{486}$ William Brown, The Ethos of the Cosmos: The Genesis of Moral Imagination in the Bible (Grand Rapids: Eerdmans, 1999). In the same way, narrative medicine, as a branch of the medical field, seeks to bring health to individuals through knowledge of their personal story. In the same way, Pentecostals must reintegrate the story of the creation to its overall theology in order to bring healing to earth. I was introduced to the notion of narrative medicine in Daniel Pink, A Whole New Mind: Why Right-Brainers Will Rule the Future (New York: Riverhead Books, 2006), 52. For a "narrative ecotheology," see Horrell, Hunt, and Southgate, Greening Paul: Rereading the Apostle in a Time of Ecological Crisis, 49-59.

${ }^{487}$ Brown, The Ethos of the Cosmos: The Genesis of Moral Imagination in the Bible. Brown's main thesis appears to be that the central importance of cosmology within religious/theological discourse is for ethical and moral constructions. For the intersection of theology to since in development of a metacosmology, see Robert Russell, Cosmology: From Alpha to Omega (Minneapolis: Fortress, 2008).

${ }^{488}$ Quoted in David Fitch, The Great Giveaway: Reclaiming the Mission of the Church (Grand Rapids: Baker, 2005), 143.
} 
pneumatological terms. ${ }^{489}$ This connection between the Spirit of God and the creation narrative, which endeavors to speak to the ecological crisis, helps to reinstate a holistic vision that sees the two eternally connected in this interconnected universe. ${ }^{490}$ For if the Spirit of God creates and lives in creation and God's people, the two are being restored to relationality. Both Pinnock and Chan view relationality as the very strength of Pentecostal theology and practice. ${ }^{491}$ That is a view of God that "follows experience." $" 492$ Ultimately that is the strength of the Spirit/creation theologies we have seen: renewed relationship.

Finally, we turn to the distinctive Pentecostal ecotheological approaches based on healing (Harold Hunter), shalom (Jared Boone), and the "four-fold" gospel (Matthew Tallman and Shane Clifton). Harold Hunter's approach examining the healing motif of ecotheology is an accommodating opening, although at times feeling more apologetic than constructive in nature. What Hunter does that few others have undertaken is an approach that makes room for the earth in what early Pentecostalism and the book of Acts emphasizes: healing as a salvific act. Boone's shalom theology similarly seeks

\footnotetext{
${ }^{489}$ A creative phrase borrowed from John Haught in John Haught, "Religious and Cosmic Homelessness: Some Environmental Implications," in Liberating Life, eds. Charles Birch, William Eakin, and Jay McDaniels (Maryknoll: Orbis, 2002), 159-181 (159).

${ }^{490}$ I was assisted in my thinking regarding "inter-relatedness" of creation and all time-centered activity in Ruth Page, Ambiguity and the Presence of God (London: SCM, 1985), esp. ch. 2.

${ }^{491}$ Pinnock, "Divine Relationality." Regarding this Pentecostal relational experience, Simon Chan has suggested that Pentecostal theology inherently—through the immanent Spirit—emphasizes God's immanence over transcendence. Chan, Spiritual Theology, 38.

492 Quoted in Pinnock, "Divine Relationality," 9. As mentioned, in this sense PC theology has an embedded form of empiricism, a theological knowledge that often follows spiritual experience. This perhaps explains why Simon Chan's cultural-linguistic approach borrowed from George Lindbeck in understanding practice in Pentecostal communities is so intriguing. Yet to be clear, Pentecostal experience depends on how one defines Pentecostalism. I follow Chilean Pentecostal Juan Sepulveda's argument that Pentecostalism consists not of new doctrine per se, but rather "[p]entecostalism offers a new and direct experience of God, bypassing any foreign cultural or priestly mediation." Thus experience transcends the doctrinal —or rather-relationality to God through the Spirit is the Pentecostal doctrine. See his Sepulveda, "Future Perspectives for Latin American Pentecostalism," 191.
} 
healing through giving rest to the land. Soteriology, in regards to the healing of the world here and now, has peculiarly been silent regarding creation and ecological care. But the strength of an approach based on healing will ultimately attempt to renew the relationship aspect of human and nonhuman creation. Healing, for Pentecostals, happens by the laying on of hands. This makes the healing of creation a dynamic form of experiential theology. Kärkkäinen speaks of a yada-kind of knowledge that Pentecostals will be drawn to as they attempt to relationally experience the God of the universe, each other, and the surrounding cosmos, practicing an embodied creational relationship. ${ }^{493}$ This yada-kind of relationship would be one based on action and praxis. Perhaps this is good for Pentecostals who, Murray Dempster has suggested, give more attention to acting than thinking. ${ }^{494}$ In the face of the biblical text, Pentecostals are likely to say, "Great ideahow can we do it?"495 The "four-fold" gospel approach is an attempt at showing how contemporary Pentecostalism has perhaps fallen short of its original vision of salvation that embodied all of creation, though important, does not fully create an ecotheological future in conversation with others and would most likely have a challenging time being in dialogue with those outside Pentecostalism. While possibly helpful within, the framework of the "four-fold" gospel would limit its usefulness outside Pentecostal movements.

\footnotetext{
${ }^{493}$ Yada is the Hebrew idea of "knowledge" which emphasizes personal and intimate knowledge (even sexual in some cases). On this “yada-kind of knowledge," see Kärkkäinen and Yong, eds., Toward a Pneumatological Theology, 16. This follows, in a sense, Michael Polanyi's classic argument that knowledge comes through personal interaction and relation, not dispassionate objective scientific observation. Polanyi's overall argument is a central criticism of so-called "scientific detachment." See his salient text Michael Polanyi, Personal Knowledge: Towards a Post-Critical Philosophy (Chicago: University of Chicago Press, 2000), esp. introduction.

${ }^{494}$ I borrow Dempster's language here. Dempster makes the case elsewhere that Pentecostals have notoriously been "doers" rather than "reflective thinkers" on such issues as social justice. Dempster, Klaus, and Petersen, Called \& Empowered: Global Mission in Pentecostal Perspective, 3.

${ }^{495}$ Thanks to Charles Lee's Cultural Ministry course at Life Pacific College in San Dimas, California for listening to a one-hour presentation on Pentecostal ecotheology and responding with this simple classic Pentecostal question. This resonates, I believe, with Aristotle's idea of phronesis, which is the interdependence of theory and practice.
} 
Tallman's work, which is in many ways similar to Clifton's work utilizing the "four-fold" gospel, provides us with a very accommodating contribution in two main ways. First, Tallman rightly isolates a theme of Pentecostal history in healing as an essential theme of Pentecostal ecotheology. While it is doubtful any of the early prePentecostal or Pentecostal thinkers envisioned the healing of the Holy Spirit in ecological terms as it pertains to the wholeness of all creation, ${ }^{496}$ it is at least an opening for further theological development. This is the strength of Tallman's development: his extrapolation of the "four-fold" gospel beyond theory to theological development. Secondly, his examination of pneumatological ecology is a promising endeavor. He rightly concludes that the ecumenical turn to "pneumatological imagination" $" 497$ has opened the doors for Pentecostals to enter the conversation. Engaging both Moltmann and Pinnock proposes a thoughtful stimulation point for Pentecostals to expand their own “pneumatological imagination” regarding ecological care.

We have come to a point where we have examined the voices of those who have helped shape PC ecotheology. This chapter has attempted to outline three main trajectories of PC ecotheology: PC social justice theology, Spirit/creation theologies, and distinctive ecotheological approaches in Pentecostalism. And it would be my conclusion, following this analysis of the literature within Pentecostal scholarship on the topic of ecotheology, that there is both somewhat of a lacking of ecotheological writings yet the beginnings of a pneumatological approach to creation upon which to build. And it is on that foundation we continue. Where do we go from here? Our next chapter will continue

\footnotetext{
${ }^{496}$ I agree this is debatable. Tallman points to Wesley's "prayer for the lame horse" as well as William Branham's prayer for a sick opossum.

497 Yong, The Spirit Poured out on All Flesh.
} 
deeper by engaging three ecological thinkers who have articulated both an ecotheology, which incorporates an ecopneumatology, that will allow us a dialogue partner as we eventually lay out a Pentecostal ecopneumatology. 


\section{Chapter 4 \\ THE SPIRIT CLIMATE-RECENT ECOPNEUMATOLOGICAL PARADIGMS}

\subsection{Introduction}

This chapter will deeply engage three critical dialogue partners in the study of ecopneumatology. Before continuing, we must consider where we have come from and where we are going. We began our study by overviewing Christian ecotheology in chapter 2 and focusing more deeply on PC ecotheology in chapter 3. Now, before moving closer to constructing a Pentecostal ecotheology of the Spirit in chapters 4 and 5, we set our task in motion of examining how ecopneumatology is being constructed and how it is shaping the broader field of Christian ecotheology. As mentioned from the onset, we will focus our attention on three dialogue partners: the "Biocentric Spirit" of Denis Edwards, the "Hopeful Spirit" of Sallie McFague, and the "Wounded Spirit" of Mark Wallace. In regards to each dialogue partner, we will set out to accomplish three goals. First, we will examine the thrust of their overall ecotheological schemata. Secondly, in context of their overall ecotheological endeavors, we will seek to understand the relationship of their ecotheology to the person and work of the Holy Spirit. And thirdly, we will assess each within a concluding analytical section with suggestions for a Pentecostal construction. As we shall see, each contributing theologian will raise an important set of particular issues common to their differing interests and settings. It is my hope that these three dialogue partners will help assess how pneumatology has shaped their own ecotheological 
construction, serving as dialogue partners for a Pentecostal ecopneumatology in the final chapter.

This is not the first time a Pentecostal theology has attempted such a dialogue with the broader ecopneumatological field. In a 2005 article, Amos Yong attempted to wrestle with the ecotheology of three important figures - Sallie McFague, Denis Edwards, and William Dembski_-illustrating a striking openness to pneumatological models outside his own Pentecostal framework. ${ }^{498}$ Yong's article concludes with an important section on the possibilities and practicalities of a pneumatic comprehension of a natural world with explorations into the world of psychology, parapsychology, clairvoyance, and telepathy. Similarly, Yong suggests a number of reasons why the biblical creation narratives — read through a pneumatological hermeneutic — are increasingly key for a fruitful religious/science dialogue. Yong's articulation, for this project, offers a foundation upon which a Pentecostal dialogue with ecopneumatology can be built.

Nonetheless, why have we chosen these three-Wallace, Edwards, and McFague - as our representative dialogue partners? Suffice it to say that many reasons remain, but two deserve mention here. First, ecopneumatology, as an emerging area of study, as of yet remains a quiet area of academic theological scholarship perpetuated largely as an "invisible college" of thinkers and practitioners. Thus, unable to rely on an official academic field for data, our three scholars will play the role of giving us models in the field. In this regard, it should be recognized that these three perhaps remain some

\footnotetext{
498 Amos Yong, "The Spirit and Creation: Possibilities and Challenges for a Dialogue between Pentecostal Theology and the Sciences," JEPTA 25 (2005), 82-110.
} 
of the most influential ecotheologians in the twenty-first century. And it is without question that their impact will continue to resonate for years to come through the field. So clearly, their undeniable widespread influence within and outside their own working traditions has shaped my choice significantly. Secondly, each scholar represents by and large a uniquely different theological tradition and ecotheological approach. As will be discovered, Denis Edwards (Roman Catholic), Sallie McFague (Ecofeminist), and Mark Wallace (Protestant) each offer us a distinct voice in representing each of the three major fields already examined in chapter 2. Only for the sake of space, the Orthodox tradition lacks representation here. ${ }^{499}$ With our three case studies identified, we will now commence the chapter by examining the ecotheology of Denis Edwards.

\subsection{Denis Edwards's "Biocentric Spirit”"}

Dr. Denis Edwards is a RC theologian at Flinders University in Adelaide, Australia. Academically, Edwards received his M.A. from Fordham University and finished his doctorate in theology from the Catholic University of America (CUA). Broadly, his scholarly pursuits have primarily orbited around ecotheology, doctrine of creation, ecological politics, Christological ecology, and the larger science/theology dialogue. For our purposes here, his ecotheological sketch will be a much-needed dialogue partner, particularly in relation to his theology of the Spirit and creation. As we will see, the scope of his ecotheological paradigm has embodied two central thrusts. The first is that

\footnotetext{
499 Future scholarship, both Pentecostal and ecotheological, must continue to give careful attention to Orthodox ecotheology as a viably helpful conversation partner. Again, sadly for the sake of space this will not be possible here.
} 
Edwards's ecotheology has focused largely on Christological models as intersect with our understanding of the earth. With this, Edwards offers an intriguing dialogue with patristic and early Western Christological models for a reimagined creation theology on a contemporary level. Secondly, perhaps the most influential in scope, is his pneumatological rendering of creation in the context of the ecological crisis. As with any theologian, his hermeneutical preferences, methodology, and scholarly interests have shifted somewhat in his later work. A reading of Edwards's span of work illustrates an interesting shift in thought from earlier Christological theological developments in Jesus and the Cosmos $(1991)^{500}$ to the more recently published pneumatological texts, such as Breath of Life (2004). ${ }^{501}$ The latter offers his most developed ecopneumatological work to date. Most recently, Edwards's Ecology at the Heart of Faith (2007) gives a more popular account of his own theological sketch, giving the general reader a simplified overview of his pneumatological program in the setting of a synthesis of his ecotheology readable to the general public. ${ }^{502}$

Beginning with his main Christological text Jesus and the Cosmos (1991), Edwards brings the theme of the cosmic Christ into dialogue with the new cosmology (e.g. "Big Bang," expanding universe, Newtonian physics), while including other more recent ecological findings. ${ }^{503}$ In an attempt to minimize the growing dichotomy between Western Christian theology and emerging scientific findings, Edwards employs the theological trajectory of Karl Rahner's cosmological theology. With Rahner and the

\footnotetext{
${ }^{500}$ Edwards, Jesus and the Cosmos.

${ }^{501}$ Edwards, Breath of Life.

502 Denis Edwards, Ecology at the Heart of Faith: The Change of Heart That Leads to a New Way of Living on Earth (Maryknoll: Orbis, 2007).

${ }^{503}$ Edwards, Jesus and the Cosmos.
} 
ecological crisis as dialogue partners, Edwards suggests the theological traditions of the Western church are too often taken for granted. This is a result of a Christian theology that ignores them based on the context of their own day. Edwards reminds us these traditions will all remain children of their own cultural time frame assuming both the scientific and theological worldview of their ages — but their theology will not. Edwards illustrates this with the case of St. Thomas Aquinas whose world still remained static, fixed, and earth-centered. ${ }^{504}$ Yet Aquinas, and others, still have something important to teach us regarding a contemporary theology of the earth. Undeniably the Western theological legacy was inevitably shaped by the known world. Neither Aquinas, Luther, nor St. Bonaventure had knowledge of evolutionary theory or a Sun-centered galaxy as the modern and late modern eras do. This is similarly the case, Edwards writes, in premodern comprehensions founded on Platonic models of the body, soul, and spirit, which ultimately seem to have led to devaluation of the matter both of the human body and the sacrament of creation. ${ }^{505}$ For the premodern person, the world was still a flat one. And it was in that flat world where they envisioned God's Spirit. Furthermore, it is in that way Edwards forwards the challenge to the ecotheological community that it must, in its ongoing efforts, keep up with the Western historical expressions of the past and contemporary science. Both practices are essential to late modern ecotheology. This is no doubt juxtaposed to those ecological theologians who readily treat scientific findings with

\footnotetext{
504 Ibid., 3-6.

505 Commenting on the interconnected nature of neo-Platonism and its negative effects on the Western worldview, especially in the medieval period towards creation, Edwards writes, "Naturally, this has led to a devaluing of the body and Earth itself." Ibid., 24.
} 
dislike or disregard. Edwards takes careful account to include findings in science and evolutionary theory to inform his theology as a method of example. ${ }^{506}$

Following Jesus and the Cosmos, Edwards expanded his Christological focus with a fresh work in $1995 .{ }^{507}$ Here, he attempts to recover a wisdom Christology based on the incarnational nature of God's being in the person of Christ with specific mention to various ecological implications. Edwards does this through utilizing the personal wisdom (Sophia) nature of Christ as well as the wisdom literature of the Hebrew biblical narratives of Proverbs, Sirach, and the Wisdom of Solomon. In the preliminary section, Edwards unveils his Christological model. The second section seeks to recover a model of mutual Trinitarianism, touching again on the thought of Richard of St. Victor and St. Bonaventure. The text similarly relies on a dialogical framework with Zachary Hayes, Elizabeth Johnson, Sallie McFague, and Rosemary Ruether. As Edwards argues later (chapter 6), the intersubjective nature of Christ, along with his vulnerability towards creation in his incarnation, leads to a renewed soteriology that "embraces the universe. ${ }^{, 508}$ This incarnational vision—with special attention given to the theological nature of everyday praxis — of a Christian practical anthropology grasps the nature of human interrelatedness with creation. This kind of relatedness is possible, not as from

\footnotetext{
${ }^{506}$ This same theme is seen in other works, such as Denis Edwards, Made from Stardust: Exploring the Place of Human Beings within Creation (North Blackburn: Collins Dove, 1992); Denis Edwards, "Every Sparrow That Falls to the Ground: The Cost of Evolution and the Christ-Event," ECO 11.1 (2006), 103123.

${ }^{507}$ Denis Edwards, Jesus the Wisdom of God: An Ecological Theology (Maryknoll: Orbis, 1995).

${ }^{508}$ Ibid., 133.
} 
above, but from below ${ }^{509}$ This similar incarnational theme is exhibited throughout his

later work. ${ }^{510}$

As it should, an incarnational shift such as this by Edwards gives careful attention to the Trinity as it relates to ecopneumatology. This is represented by Edwards in his Jesus the Wisdom of God. It is here where he illustrates both the importance of the "immanent Trinity" and a Spirit-Christology—-the Spirit's role and relationship to the life, death, and resurrection of Christ. ${ }^{511}$ Edwards points out that in the four NT Gospel traditions, a consistent trend is made manifest: Mark's account demonstrates the Father's Spirit as one who descends on Christ, Matthew's Spirit conceives the person of Jesus, Luke-Acts Spirit anoints Jesus for service and Messiahship, and John's Spirit rests upon Jesus. ${ }^{512}$ For Edwards, this Spirit-Christology is an important key to understanding Jesus on a relational basis. Trinitarian relationality, therefore, in line with a scientific comprehension of constitutive relationships where each part gathers together to form a whole proposes a unique theological understanding. Here, wholeness and mutuality flow from God's interrelational Father-Son-Spirit relationship. ${ }^{513}$ It is as humanity opens

\footnotetext{
${ }^{509}$ Edwards further suggests there remain seven theological practices that should overflow from a Christological ecology based on incarnation: a renewed understanding of the intrinsic value of all creation and human beings, a reverence for life, the interdependent nature of biotic life, criteria for ethical discernment, ecological sustainability, a kinship with other creatures in the earthly order. Ibid., 153-171. ${ }^{510}$ E.g. Edwards, Breath of Life, 66-86.

${ }^{511}$ Edwards, Jesus the Wisdom of God, 118-122.

${ }^{512}$ Interestingly, compare this to the overall usage of the Spirit in each of the canonical gospels. Joseph Fitzmyer has pointed out that Mark has six references to the Spirit, Matthew twelve, John fifteen, Luke eighteen, and Acts fifty-seven. Joseph Fitzmyer, The Gospel According to Luke I-IX (New York: Doubleday, 1981), 227.

513 This theme continues throughout Edwards's later work where he bases his Trinitarian theology on dialogue with John Zizioulas, Catherine LaCugna, Colin Gunton, and Elizabeth Johnson. This God as "person-in-relation" leads to a model of ecological egalitarianism where creation as seen as an overflow of God's personal relationality. Denis Edwards, "A Relational and Evolving Universe Unfolding within the Dynamism of the Divine Communion," in In Whom We Live and Move and Have Our Being, eds. Philip
} 
itself up to a relational Trinity, focusing less on the divine nature of Christ and more on his inter-Trinitarian relationality, that new cosmological advances stressing relationality will be made possible to greater nurture humanity's relationship to earth.

Edwards's The God of Evolution (1999) furthers a possible dialogue between ecological Trinitarianism and evolutionary theory set out with a clear orientation. Edwards contends, "[T]he foundation for a theology that takes evolution seriously can be found in the Trinitarian vision of God as a God of mutual relations, a God who is communion in love." ${ }^{514}$ In this mutual Spirit all of the cosmos is welcomed in relationship. Elizabeth Johnson has highlighted a similar point regarding the nature of the Spirit in her work, writing, "to be structured so that you have room inside yourself for another to dwell is quintessentially a female experience." ${ }^{.515}$ This God makes room for creation within the divine nature. God's Spirit makes room in love for all of creation. What does this vivifying, life-giving, room-making Spirit do on behalf of creation? With both the Trinity and evolution in dialogue, Edwards argues four central Spirit-images remain essential to both an ecological and Trinitarian theology: the Spirit is life-giver, the power of becoming, the interior presence of God, and the ecstatic communion-bringer. ${ }^{516}$ After noting this, Edwards will show how each has a pronounced role in his emerging ecopneumatology. For instance, the power of becoming shows the Spirit creating avenues for biological development amongst the living ecosystem, such as evolutionary theory has suggested. In a way, pointing to Aristotle, the Spirit is seen as the entelechy, or the

Clayton and Arthur Peacocke (Grand Rapids: Eerdmans, 2004), 203-205. Give attention to, as well, his interaction with Elizabeth Johnson throughout his Edwards, Jesus the Wisdom of God.

${ }^{514}$ Denis Edwards, The God of Evolution: A Trinitarian Theology (New York: Paulist, 1999), 15.

${ }^{515}$ Carol Jegen, "Review of the God of Evolution: A Trinitarian Theology," RE 94.4 (1999), 464-465.

${ }^{516}$ Edwards, The God of Evolution, 98. 
self-inner direction to one's being to return to a natural state of being or ordering. ${ }^{517}$

Drawing on the Johannine tradition, Edwards argues that from the beginning of John's

gospel (John 1:32-34) the Spirit is portrayed as abiding on Jesus and his ministry; a

theme that continues to emerge throughout John's gospel. ${ }^{518}$ As did the dove on Jesus, the

Spirit abides in creation. In this way, for Edwards, evolutionary theory is quite

compatible with God's Trinity, a God of "mutual relations," as seen through this theology

of abiding. ${ }^{519}$

This theme of abiding assumes a Trinitarian framework. Likewise, a Trinitarian

framework is necessary for an ecological ethic. For, without a reliance on both Word and Spirit, Trinitarian theology is given "no role" in creation. ${ }^{520}$ Edwards reminds us that Trinitarian language can easily be boiled down to Father-Son language, creating an image of the church as a patriarchal society. To protect against this, what is needed is a return to Logos and Wisdom language, both of which are open to ecological discourse found in OT hymns, the patristic writings, and more specifically that of the theology of Wolfhart Pannenberg. ${ }^{521}$ To this end, Edwards turns his readers' attention to extant patristic texts to retrieve Trinitarian sources, dialoging with Basil of Caesarea's (320-379 C.E.) Against Eunomius and On the Holy Spirit. In doing this, Edwards connects the pneumatological

\footnotetext{
${ }^{517}$ On this further, see David Coffey, "The Spirit of Christ as Entelechy," PTH 13.2 (2001), 363-398. Interestingly, this concept of entelechy is discussed in conversation with a Pentecostal theology of "keeping in step with the Spirit" in Steven Studebaker, "Creation Care as 'Keeping in Step with the Spirit'."

${ }^{518}$ E.g. John 1:38-39; 6:27, 56; 14:2, 10-11, 15, 21, 23; 15:7.

${ }^{519}$ Edwards, The God of Evolution, 14-34.

${ }^{520}$ Ibid., 78.

${ }^{521}$ This is his point in Denis Edwards, “The Ecological Significance of God-Language," TS 60.4 (1999), 708-722.
} 
concepts of the creative and perfective natures of the Creator Spirit. ${ }^{52}$ Here, Basil's consistent inclusion of the Word/Spirit dialectic proffers a revelatory mutual nature of the Trinity for a joint vision of creation. This same sort of method is present on a more contemporary basis in the work of Orthodox theologian John Zizioulas, who has been a consistent mantle bearer of communion theology emphasizing this egalitarian Trinity in a contemporary theological culture which tends to atomize the Trinity. ${ }^{523}$ This nonatomistic and nonindividualistic Trinity forcefully awakens us not only to a cosmic Christ, but also a cosmic Spirit where "every phase of the divine work of our salvation is preceded by the presence and activity of the Holy Spirit.. ${ }^{, 524}$

For Edwards, this Trinitarian point is never lost in Rahner's original vision. The Spirit becomes a sort of prevenient grace not only to human conversion, relationship, and economy, but ecological systems and relationships as well. The Trinity, therefore, emerges as a model for God's interrelationship to the created world. Now we are shown the centrality of the Spirit to the ecological economy. The Spirit, as the magnet of the divine communion, draws all that is not divine into the divine life-including the entire ecological order. ${ }^{525}$ This happens as the Spirit draws all towards her in love. Richard of St. Victor earlier had called this the condilectus, "the one who shares in love for the beloved and is loved with the beloved.. ${ }^{, 526}$ In almost Augustinian terminology, the Spirit lovingly holds creation together. This gives human vocation and work in the created

\footnotetext{
${ }^{522}$ Loosely based on Psalm 33:6, which reads "By the word of the Lord the heavens were made, and the hosts by the breath of his mouth."

${ }^{523}$ This is best constructed in his Zizioulas, Being as Communion.

${ }^{524}$ Edwards, The God of Evolution, 81.

${ }^{525}$ Ibid., 95-100.

${ }^{526}$ Ibid., 96.
} 
order a new context. Citing Zizioulas, Edwards points out that it is for this reason Orthodox theologians tend to speak of the human agents as the priests of creation. On behalf of the Spirit, these priests of creation are called to live out the dynamic image of the loving Spirit by serving the cosmos from below. ${ }^{527}$

Undoubtedly, Edwards's most substantive ecopneumatological text remains his Breath of Life (2004). ${ }^{528}$ Within, Edwards argues for a "holistic theology of the Spirit, one that begins not with Pentecost but with the origin of the universe 14 billion years ago." ${ }^{, 529}$ Edwards writes, "I will suggest that the full story of the Spirit involves not simply the one episode of Pentecost but our great episodes: creation, grace, the Christevent, and Pentecost. ${ }^{, 530}$ In Breath of Life, the preliminary chapters (I-II) - upon which the remainder of the text builds - tell of his methodology. First, he builds on modern scientific developments (e.g. "Big Bang," Evolutionary Biology, cosmology) and expands an interplay, first with theology, and secondly, a pneumatological assessment and reconstitution of Basil. Bringing the two in dialogue, God's Spirit is envisioned as resplendent throughout creation creating a new comprehension of the story of the universe as an interconnected entity. This story inaugurates at the initial second of time during the "Big Bang." This story depicts the emergence of the nuclei of hydrogen and helium developing into atoms, galaxies, stars, the solar system, earth, and eventually life on earth. All of this, as we begin to see creation weaved together, is part of the Spirit's

\footnotetext{
527 John Zizioulas, "Preserving God's Creation: Three Lectures on Theology and Ecology," KTR 12 (1989) $1-5,41-45$.

${ }^{528}$ Edwards, Breath of Life.

${ }^{529}$ Ibid., 1, (italics mine).

${ }^{530}$ Edwards, Ecology at the Heart of Faith, 30.
} 
work— the Creator Spirit.${ }^{51}$ Chapter 2 utilizes Basil's pneumatology for an emerging dialectic between pneumatology and scientific understandings of the created order. As in his previous text, the Spirit's love is emphasized as vital to the interconnectivity of the universe. On this pneumatological grace, Edwards writes, "The whirlwind wild Spirit is the boundless love at work in the processes of the universe." ${ }^{532}$ While in this context of love, the Spirit is also enigmatic and unpredictable. Edwards's evolutionary pneumatology further will build on the biblical theme of the Spirit as the unpredictable wind (John 3:9) blowing new and creative life throughout creation. ${ }^{533}$

Reflecting on the Spirit's life in creation, Edwards ponders, "How is the lifegiving Spirit connected to the world of whales, kookaburras, and grevilleas?" ${ }^{934}$ The answer, for Edwards, lies in a more historically sensitive view of the Spirit in creation that can embrace such views as evolution. ${ }^{535}$ Drawing on Pannenberg's emerging pneumatology, the Spirit is the conscious power and force hidden behind ecological and evolutionary growth and development. Edwards continues, "I see the Spirit of God as the power of the future, immanent in all the processes of the evolving universe, enabling it to become what is new. ${ }^{5536}$ Furthermore, Edwards points out that caution must be had in this evolutionary pneumatology. The evolutionary Spirit as creatio continua is not to be

\footnotetext{
531 The opening words are telling of his methodology. He writes, "The stunning world opened up by "Big Bang" cosmology and evolutionary biology calls for a renewed theology of the Creator Spirit." Edwards, Breath of Life, 1. As well, see ibid., 10-13.

532 Ibid., 34.

${ }^{533}$ Ibid., 35-39.

${ }^{534}$ Edwards, Ecology at the Heart of Faith, 27. Later, Edwards uses this pneumatological vision to respond to Steven Hawkins's famous question at the conclusion to his groundbreaking popular book, Hawking, $A$ Brief History of Time, 174.

535 The connection between relational theology, the Trinity, evolution, and communion is unpacked in his Edwards, "A Relational and Evolving Universe Unfolding within the Dynamism of the Divine Communion."

${ }^{536}$ Ibid., 208.
} 
confused with "occasionalism," a view that paints God as intervening to bring about a new biological or creaturely direction. ${ }^{537}$ God does not make new species, rather, $\mathrm{He}$ simply creates space and openness for the possibility of newness in the same way he creates space for humans to procreate. So the Spirit is not to be understood as an extension of an interventionist or controlling God.

The Spirit is surprisingly multidimensional in Edwards's theology. For instance, he addresses a nuanced distinction between the "inwardness" and "outwardness" of the Spirit, following both Rahner and Aquinas. Creationally, the Spirit plays two integral roles. The first is as the internal power that outflows into matter and body. In this way, the human body is in some sense both Spirit and material. ${ }^{538}$ But, as well, the Spirit has an outward role of drawing humanity into God's communal life of the Trinity. This multidimensionality is seen elsewhere, such as in his dialogue between the patristic and modern evolutionary theories. This is no better seen than in Breath of Life, where Edwards proposes seven key comprehensions of the Spirit drawn from biblical, patristic, and contemporary scientific sources:

1. The Spirit should be conceptualized as the Breath of God, breathing life into a universe of creatures.

2. The Breath of God and the Word of God act together in creation.

3. The Spirit of God is the source of the new in an emergent universe.

4. Creation is a relationship - a relationship between each creature and the divine communion.

5. The Spirit is the Communion-Bringer, the indwelling creative presence that relates each entity with the divine Communion.

6. In the Creator Spirit, God is present to each creature, embracing each in love.

\footnotetext{
${ }^{537}$ Edwards, The God of Evolution, 89. Edwards argues further for a "non-interventionist" approach to evolution in dialogue with Rahner. See also Denis Edwards, "Resurrection and the Costs of Evolution: A Dialogue with Rahner on Noninterventionist Theology," TS 67.4 (2006), 816-833.

${ }^{538}$ Edwards, Jesus and the Cosmos, 85-86.
} 
7. Through the indwelling Spirit, creatures of the universe are brought into communion with one another. ${ }^{539}$

As elsewhere, taking his cue from Rahner, Edwards suggests an element of this "inwardness" is what is called an "active-self transcendence"- a presence amongst and enabling created beings to morph and transcend beyond themselves. ${ }^{540}$ This transcendent process can be categorized as the work of the Holy Spirit. Creation, in free love, is an open system of possibility. And this possibility creates space and freedom to grow, mutate, and evolve into new arenas of awareness, possibility, and potential. Rahner had alluded to this transcendent concept of the Spirit as the one who allows for what he called the "going beyond." 541 This "going beyond" is illustrated in all avenues of life for Edwards (vis-à-vis Rahner). Philosophically, the human being has incredible openness to develop and critically think to new levels of creativity and awareness. Theologically, God's grace allows the human being to new spiritual things, "to become children of God" (John 1:12). Biologically, the Spirit was present in the evolution of homo erectus. ${ }^{542}$ Edwards even draws attention to native views of the Spirit as comparisons to the Trinitarian Spirit. He compares the work of this transcendent Spirit to the prevenient Spirit among the preindustrialized people of Australia, illustrated with Pedro Fernandez de Quiros (1605), a Portuguese missionary set out to discover the land of the terra

\footnotetext{
${ }^{539}$ Edwards, Breath of Life, 47-49.

${ }^{540}$ Edwards, The God of Evolution, 89. For a concise extrapolation of Rahner's concept, see Karl Rahner, "Evolution: II. Theological," in Encyclopedia of Theology: A Concise Sacramentum Mundi, ed. Karl Rahner (London: Burns and Oats, 1975). For a focus on Christological evolution from Rahner, see Karl Rahner, "Christology within an Evolutionary View of the World," in Theological Investigations (London: Daron, Longman, and Todd, 1966), 478-488.

${ }^{541}$ Edwards, Breath of Life, 52.

${ }^{542}$ Edwards engages Richard Leakey, whose work has suggested that we know little to nothing of the earliest human consciousness. See ibid., 51; Richard Leakey, The Origin of Humankind (New York: Basic Books, 1994).
} 
Australis, thus bringing the gospel to the indigenous peoples. Edwards points out that Quiros called the Australian land the Australia del Espiritu Sancto-_"Australia, the land of the Holy Spirit." ${ }^{, 543}$

Edwards echoes Niels Gregersen's concept of the deep incarnation whereby God's incarnation in the person of Christ demonstrates a new side to the green face of God and how we experience this green God. ${ }^{544}$ In the person of Christ, from a very atomic level, God's creation has a new experience with the divine life. ${ }^{545}$ This same relationship is discussed in Edwards's Eucharistic approach to ecology in a later work. ${ }^{546}$ A communal understanding will illuminate our view of God's relationship to creation as often discussed in Breath of Life. Furthering this in a later writing, Edwards makes six qualifying remarks on his own theological agenda in regards to panentheistic "all-thingsin-God" ecotheology. ${ }^{547}$ First, panentheism must be understood in Trinitarian terms. ${ }^{548}$ Secondly, panentheism must see God as wholly immanent and transcendent towards all creation. Thirdly, the "spatial image of all-things-in-God as an appropriate but limited analogy. ${ }^{, 549}$ Fourthly, God, by his creative nature, gives all beings proper respect to live

${ }^{543}$ Edwards, Breath of Life, 50, 51.

${ }^{544}$ Edwards first published book dealt with the topic of experience and the human experience of God. Denis Edwards, Human Experience of God (New York: Paulist, 1983).

${ }^{545}$ This model is found in Niels Gregersen, "The Cross of Christ in an Evolutionary World," DG 40.3 (2001), 192-207 (205).

${ }^{546}$ In this "Eucharistic theology," Edwards establishes how the "shared table" offers a powerful sign of unity with the fruits of creation in the context of life, death, and resurrection of Christ. He similarly takes effort to converse with the Orthodox position regarding Eucharistic ecology with eschatological undertones. Denis Edwards, "Eucharist and Ecology: Keeping Memorial of Creation," WSH 82.3 (2008), 192-213.

${ }^{547}$ Edwards, "A Relational and Evolving Universe Unfolding within the Dynamism of the Divine Communion," 199-202.

${ }^{548}$ Defining the Spirit as the "interior divine presence empowering the evolution of the universe from within, enabling a universe of creatures to exist and to become." Quoting Augustine, in the Spirit, God is interior intimo meo - "closer to me than I am to myself." Ibid., 200.

${ }^{549}$ Ibid. 
as they please in freedom. Fifthly, panentheism sees creation as "a free act of divine selflimitation." ${ }^{550}$ And finally, panentheism sees creation as a relational contract that affects both creation and the Creator.

Touching on the essential chaotic nature of creation, Edwards has misgivings about a Christian theology of the Spirit that offers a romanticized view of creation where death, pain, and toil are not given free expression. The Spirit should, therefore, be understood as incarnated in these painful creational toils. Edwards writes, "Christian theology has no theoretical answer to the issue of pain and death and nature...[other than] its witness to the death and resurrection of Jesus." ${ }^{551}$ Hence, pneumatology, not as an explanation of creational suffering, becomes a healthy response and setting to this suffering where the Spirit is "the midwife of a new creation." 552 Edwards points out that this image, utilized by Paul, very well may have historical connection to Greek culture, which understood the spring season as compared to a woman giving birth. ${ }^{553} \mathrm{We}$ find this nature of the Spirit paralleled with the Pauline concept of the kenosis or "self-emptying" (Phil. 2:5-11). It is this kenotic model that is expected to be lived out in Christian community through service, love, and foot washing. Turning this understanding of Christ towards the self-consistent Godhead in the Spirit, it "can be understood to govern not just the story of Jesus and the church but also God's creative presence to all creatures in the

\footnotetext{
550 Ibid., 201.

551 Edwards, Breath of Life, 106.

552 See Edwards's chapter entitled, “The Spirit as Midwife and Companion as Creation Groans in Giving Birth.” Ibid., 105-116.

${ }^{553}$ He echoes Fitzmyer at Joseph Fitzmyer, Romans: A New Translation with Introduction and Commentary, Anchor Bible Commentary (New York: Doubleday, 1993), 509.
} 
Spirit." 554 This kenotic Spirit makes room for others, such as the creatures of the world. Creation should be seen as an act of love between the three members of the Trinity. ${ }^{555}$

This evolutionary pneumatological turn is the reason Edwards addresses creation as having an "unfinished character." 556 A pneumatological creation is one that is in process. Moltmann similarly argues for the "unspeakable closeness of God" to creation in the Holy Spirit, a theological pneumatology that has heavily influenced ecopneumatologies of all three of our representative thinkers. ${ }^{557}$ Pneumatology, therefore, must be ready to imagine a Spirit that can suffer alongside creation as it evolves and grows. From Aquinas on, to speak of a God who suffered alongside creation was largely an impossibility. Moltmann's theology of the suffering of God has influences this tendency and impacted Edwards. This is why Edwards depicts the Spirit as such that goes beyond a stagnant ghost in creation, but the very Spirit that evolves creation to greater modes of life. This synthesis of pneumatology and evolutionary biology, including a full exegesis of both primary biblical sources and apocryphal texts, uniquely creates a touch point for theology as well as scientific exploration. Edwards continues the tradition set before him in the works of Rahner and especially Chardin, whose Omega point theology shapes heavily Edwards's marriage of pneumatology to evolution. But this requires interconnectivity, not a passive God as deism has often imagined.

Crucial, as well, to Edwards's thought is an understanding of patristic pneumatology informed by the contextual pneumatology of the Cappadocian fathers,

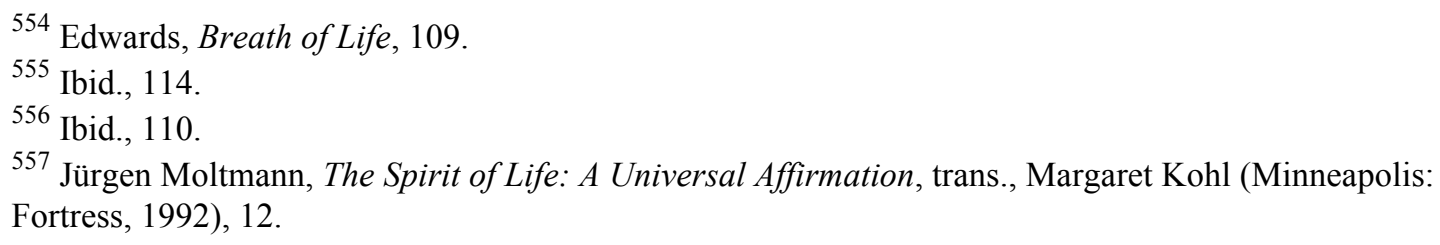


including Basil (330-379), Gregory of Nazianzus (329-389), and Gregory of Nyssa (335394). Most promising for Edwards is Basil, whose Trinitarian communion pneumatology remains a salient launchpad for his theology of communion. Edwards writes in regards to Basil's theology, "Trinity as communion and the Spirit as Breath of God that always accompanies the Word." 558 For in Basil, the most utilized image of the Holy Spirit is that of the Breath of God who always accompanies the Word, a breath that includes the infilling of both the believer and biotic life. ${ }^{559}$ The Cappadocian fathers helped see the early theology of the Trinity in light of the uniqueness of the Spirit as well as the unified nature of the Trinity. Although their theology of the Spirit "got off to a slow start" by being more focused on a theology of the Logos (Christ incarnate), it soon began to blossom. $^{560}$

Yet Edwards makes the case that this distinction (uniqueness and unification) must be kept in its proper place. ${ }^{561}$ For instance, Edwards points out that a danger of an imago Dei theology is that if used to put human beings above other creatures to abuse and use for their own ends, it becomes an image that must be a "destructive distortion" of a divine image that is intended to give life and authority to steward. ${ }^{562}$ It can emphasize the unique, over the unified tension in human existence. Even though the distinction between humans and nonhumans should remain in place, this imago Dei is different from the

\footnotetext{
558 Edwards, Breath of Life, 2.

559 Ibid., 26.

${ }^{560}$ Ibid., 39. See as well Edwards's treatment of the subsequent pneumatology of the patristics. Ibid., 3949.

561 Ibid., 123.

562 Edwards, Ecology at the Heart of Faith, 14.
} 
remainder of creation as an "imaging of God." ${ }^{563}$ But this must never lead us to forget our unified nature in creation, as part of creation. This kinship model of creation requires a conversion to new ways of thinking and acting. This "conversion" is the conversion that takes place when human beings once again begin to see themselves as a part of the interrelated creation as opposed to some kind demigod transcendent above it. ${ }^{564}$

Finally, for Edwards, the Cappadocian Fathers are a central model for the church ecclesial community. They proved so influential that their work is nearly repeated in the creed of Constantinople (381 C.E.), which offered the early church an initial contribution to the comprehension of the Spirit. More so, it was here the Spirit finally realized a formalized inclusion into the Trinitarian model, an inclusion largely ignored and misunderstood before. Following both Johannine and Pauline theology, Constantinople concluded the Spirit as both "Lord and Giver of Life" (zoopoion), which "proceeds from the Father. ${ }^{, 565}$ But the Spirit has always had a challenging time in the Church's theological outlook. Yet, Edwards suggests recent movements have continued for the Spirit what the Cappadocian fathers began. For instance, he points to the Pentecostal movement, the twentieth and twenty-first century ecumenical movements, and the second Vatican council (1962-1965) as signs of the Spirit's renewed life in the church. ${ }^{566}$ Along the same lines, Edwards points to three contemporary movements that he believes offer a

\footnotetext{
${ }^{563}$ Ibid.

${ }^{564}$ See a summation of this perspective in ibid., 22-26.

${ }^{565}$ Undoubtedly this was later changed to "and the Son," called the filioque controversy, which would eventually became a major point of nuance between the East and West contributing to the growing distance between the two in the years leading up to the eleventh century, when schism would be finalized.

${ }^{566}$ Edwards, Breath of Life, 87-88.
} 
nod to the same Spirit: the liberation movements, the feminist movement, and a "passion for creation." $" 567$

\subsection{Sallie McFague’s “Hopeful Spirit”}

Dr. Sallie McFague's work in the last forty years has, by far, been some of the more illuminating ecotheological work in the twentieth and twenty-first centuries. After finishing her doctoral dissertation from Yale Divinity, entitled Literature and the Christian Life, which was heavily influenced by the work of both Karl Barth and Richard Niebuhr, McFague quickly began to emerge as one of the preeminent ecotheologians of our era. ${ }^{568}$ Currently, McFague is the Carpenter Professor of Theology at Vanderbilt Divinity School (Nashville, TN) and has continued to write extensively in the areas of metaphorical theology, feminist theology, and ecotheology. Her earliest work beyond her dissertation on the intersection of literature and the Christian life engages a wide arena of topics. This includes a theology of the arts, ${ }^{569}$ philosophy and law, ${ }^{570}$ epistemology, ${ }^{571}$ ecclesiological/theological feminist discourse, ${ }^{572}$ and parabolic/narrative/metaphorical

\footnotetext{
${ }^{567}$ Ibid., 90.

${ }^{568}$ Sallie McFague, Literature and the Christian Life (New Haven: Yale University Press, 1966).

${ }^{569}$ Sallie McFague, "Theology and the Arts," TT 24.1 (1967), 93-94. Similar is her Sallie McFague, "In Praise of Play," RL 39.2 (1970), 318-319.

${ }^{570}$ Sallie McFague, "Philosophy of Law," SDS 51.4 (1968), 361-447; Sallie McFague, "Rediscovery of Ethnicity: Its Implications for Culture and Politics in America," SDS 56.1 (1973), 1-138.

${ }^{571}$ Sallie McFague, "Belief and Disbelief in American Literature," TT 25.2 (1968), 257-258; Sallie McFague, "Criticism as Dialogue," CU 7.3 (1969), 506-509; Sallie McFague, "Experience of Coming to Belief," TT 32.2 (1975), 159-165.

${ }^{572}$ Sallie McFague, "Women's Liberation and the Church: The New Demand for Freedom in the Life of the Christian Church," JAAR 39.3 (1971), 401; Sallie McFague, Family, Communes and Utopian Societies (New York: Harper \& Row, 1972).
} 
theology and theory. ${ }^{573}$ Ecotheologically, her metaphorical and linguistic approaches to theology alongside feminist and Protestant philosophies and epistemologies have been the foundation for her ecological imagination. To that end, much of her writing centers on what she calls "functional cosmology," that is, avenues whereby humans can practically care for the earth through focusing on and refining the human imagination and theological attitude. ${ }^{574}$ In this way, McFague argues, the ecological crisis is a crisis in theology. Before we examine McFague's ecopneumatology, let us overview her main contributions in the last forty years.

Most notably, McFague's earliest writings centered on what she would call "metaphorical theology" (later calling it "conceptual language"). Metaphorical theology is centered on a sensitivity to the constant tension of interpretation and negotiation. This is best represented by a three-part seminal series: Speaking in Parables (1975), Metaphorical Theology (1982), and a conclusive Models of God: Theology for an Ecological, Nuclear Age (1986). ${ }^{575}$ The first of these examines the parabolic function within the teaching of Jesus and offers a literary-critical suggestion for modern theological imagination. In Models of God, McFague suggests, in response to literalistic

\footnotetext{
${ }^{573}$ Sallie McFague, "Parable, Metaphor, and Theology," JAAR 42.4 (1974), 630-645; Sallie McFague, "Intermediary Theology: In Service of the Hearing of God's Word," CC 92.23 (1975), 625-629; Sallie McFague, Speaking in Parables: A Study in Metaphor and Theology (Philadelphia: Fortress, 1975); Sallie McFague, "Dark Interval: Towards a Theology of Story," Review of Books and Religion 5 (1976), 1; Sallie McFague, "Learning for the Whole Person: A Model from the Parables of Jesus," RL 45.2 (1976), 161-173; Sallie McFague, Metaphorical Theology: Models of God in Religious Language (Minneapolis: Fortress, 1982); Sallie McFague, "Jesus' Parables and the War of Myths: Essays on Imagination in the Scriptures," JR 65.2 (1985), 271-272; Sallie McFague, "Plurality and Ambiguity: Hermeneutics, Religion, Hope," TT 44.4 (1988), 500-503.

${ }^{574}$ For more on her "functional cosmology," see McFague, Super, Natural Christians.

575 McFague, Speaking in Parables; McFague, Metaphorical Theology; McFague, Models of God: Theology for an Ecological, Nuclear Age (Philadelphia: Fortress, 1986).
} 
fundamentalist hermeneutics, "theology is mostly fiction.. ${ }^{, 576}$ Not only so, but a literalistic hermeneutic of the Bible and theology must be held as suspect for interpretational usage in Christian community on the very basis that theological language, by nature, as a communal product, is always metaphorical and analogical. Finally, Metaphorical Theology proposes a reimagined perspective on religious language drawing primarily on David Tracy's influential The Analogical Imagination ${ }^{577}$ Here, she establishes her claim for the retrieval of the notion that all language (religious or not) is in some sense inherently ecumenical, pluralistic, and negotiable. This is especially the case in regards to Christian and religious language about God.

Continuing her response to fundamentalism and its literalistic methodology, McFague suggests that all theology must be understood as free from literalistic interpretations and be given room for a diversity of explanations. This is why McFague can contend, "no one writes the full, complete theology." 578 If we can see anything theologically, to put in Paul's words, "[w]e all see dimly." ${ }^{, 579}$ For McFague, all theology is done in dim light, causing it to be imperfect. In this way, for McFague, theological language can never fully touch God's real nature. Therefore, Christian theology is always half-complete at its very core.

\footnotetext{
${ }^{576}$ McFague, Models of God, xi.

${ }^{577}$ For Tracy's text that plays an important part in McFague's metaphorical theology, see David Tracy, The Analogical Imagination: Christian Theology and the Culture of Pluralism (New York: Crossroad, 1981).

${ }^{578}$ McFague, Metaphorical Theology, x. McFague later calls herself a "post-Enlightenment, Protestant, feminist." She goes on to call herself "skeptical, relativistic, prophetic, and iconoclastic." Later, McFague suggest that symbols, such as language in our time, either become literalized (in the context of fundamentalism) or spiritualized (in Protestant liberalism).

${ }^{579} 1$ Cor. 13:12.
} 
God-language, in this light, will always be incomplete. For when such a "complete" theology is produced, it will always prove idolatrous, forging into stone the images of the past and be unable to be reshaped into new images in light of fresh understandings in a contemporary world. This is because human language, writes McFague, "becomes idolatrous because without a sense of awe, wonder, and mystery, we forget the inevitable distance between our words and the divine reality." ${ }^{, 50}$ Ultimately, this suggests a reason as to why feminist discourse as a whole, a framework from which McFague openly writes from, gives great attention to a critique of male-dominated linguistics and semiotics in a predominately male-dominated Western culture. McFague offers her readers three preliminary reasons as to why this is the case. First, feminists suppose that the one who names the world owns and controls the world (borrowing from Heiddegerian power-play philosophy). Language and power always intersect, for to name is to have power over. Secondly, for McFague, language in the West has been inherently patriarchal and will ultimately demand revision as it has led to domination and power struggles both between the sexes and human/nonhuman creatures. And thirdly, feminist discourse in line with McFague contends that religious language, though referring as signs to the divine actually have more to do with humanity than we previously thought. Theology is inherently anthropomorphic in this regard.

Ultimately, in theology and social relations, the power to name is the power over something. No doubt, this is a challenge, at least for McFague, to patriarchal language of God as Father and Son, often leading to a sort of patriarchal colonialism. She contends, utilizing her metaphorical theology, that subscription and adherence to such images (i.e.,

${ }^{580}$ McFague, Metaphorical Theology, 4. 
Trinitarian "Father and Son") is inherently idolatrous and will in the end give credence to nonegalitarian relations between the sexes. ${ }^{581}$ Although aware that the biblical text uses such patriarchal/theological language, it must constantly be a reminder to theology that the scriptures had no choice but to use human categories to communicate the divine to humanity. A major task for theology today is therefore to free such language from the necessary marriage to categories, especially to the category of God as a man. Ultimately, the way to ease this idolatrous crisis is a use of the parabolic formula that is more ready to use image, story, and narrative over propositions, statements, and creeds. As Jesus's ministry centered on image and parable (not doctrine), so should a modern theological sketch.

In her Models of God (1986), we begin to see a development in McFague's focus towards ecological issues. ${ }^{582}$ To begin with, McFague repaints theological constructions of God and earth for a nuclear age, similar to the earlier Gordon Kaufman. ${ }^{583}$ Although, in juxtaposition to Kaufman who attempted to deconstruct modern views of the proliferation of nuclear powers, McFague argues that Christian praxis must be done very differently, fearing less the bomb and more the factory. Relationships are different than they used to be and continue to play a substantive role in this new era of understanding as technology outweighs the power of earthly creation. In terms of this new kind of relationship, McFague writes, "the question of an entity is answered in terms of its

\footnotetext{
581 Ibid., 145.

${ }^{582}$ McFague, Models of God.

${ }^{583}$ McFague, Models of God. For Kaufman's work, which sought to situate theology in a postnuclear world where God's sovereignty comes into question with humanity's ability to self-destroy at will, see Gordon Kaufman, Theology for a Nuclear Age (Louisville: Westminster, 1985).
} 
relationships. ${ }^{" 584}$ As she later will do in the later Super, Natural Christians, the basis of this relational living on an ecological level is an understanding of the Buberian I/Thou relationship reconstituted towards all nonhuman life. ${ }^{585}$

We see this emphasis on the cosmic relationships of the universe as she utilizes the metaphor of the universe as "God's Body" in her The Body of God: An Ecological Theology (1993). ${ }^{586}$ After process-oriented (Chardin) and creation theology (Berry and Fox) predecessors, the created order is envisioned as being one of relationship both with God and to each other. The Body of God offers another of McFague's seminal attempts at ecotheology based on her criticism of patriarchal language. ${ }^{587}$ Again, here, emphasis lays on the relational aspect of human/nonhuman creatures within the creation, or as she calls it "the body of God." Ecology, in essence, is a response to atomism, or the breakdown of all things into themselves as opposed to their relationship to one other. As well, McFague's metaphor of the universe as "God's Body" seeks to restructure the way we imagine "seeing" God. In the same way Moses saw God's back, so are we permitted to see part of God, God's body, the universe. ${ }^{588}$ And as we see the world as "God's Body," we have a new setting for living alongside it. For the earth is the cosmic Christ, and to care for the earth is to care for Christ's body himself. McFague pairs two important elements of the body theology: that the world is God's body and that God's spirit is what

\footnotetext{
${ }^{584}$ McFague, Models of God, 8.

${ }^{585}$ See Buber's classic text, Martin Buber, I and Thou (New York: Scribner, 1958).

${ }^{586}$ McFague, The Body of God. McFague discusses elements of this with concern to Christology in McFague, "An Ecological Christology: Does Christianity Have It?," in Christianity and Ecology, eds. Dieter Hessel and Rosemary Ruether (Cambridge: Harvard University Press, 2000), 29-45. Furthermore, her theological development of an ecological embodiment can be found Sallie McFague, "Human Beings, Embodiment, and Our Home the Earth," in Reconstructing Christian Theology, eds. Rebecca Chopp and Mark Taylor (Minneapolis: Fortress, 1994), 141-169.

${ }^{587}$ McFague, The Body of God.

${ }^{588}$ Ibid., 131.
} 
lives in the Spirit. ${ }^{589}$ This new "reimaged" vision offers us ecological hope. She concludes her work, writing, "Our efforts on behalf of our planet are not ours alone but that the source and power of life in the universe is working in and through us for the wellbeing of all creation, including our tiny bit of it." ${ }^{, 590}$

A final and conclusive work on religious language is McFague's culminating Super, Natural Christians (1997). ${ }^{591}$ Perhaps more in-depth than elsewhere, this is where McFague begins to speak of the Spirit of God in the context of the ecological crisis. Here she wrestles with the meaning of the term spirituality, which she has already argued, has been overtly reduced in the setting of Western dualism. ${ }^{592}$ She utilizes the 1977 Scottish Churches definition of spirituality as "an exploration into what is involved in becoming human. ${ }^{" 593}$ The distinction then of Christian nature-spirituality is that is exactly what the incarnate God did, becoming, in a sense, earth in human form. God no longer remains something far off, but has taken on flesh, bones, toenails, and earth itself. But here her comprehension of the Spirit seems to play more a part of becoming and emerging into humanity as opposed to a part of the Trinity.

In the same text, McFague attempts to construct a new setting for Jesus's social teaching on love for the neighbor that is extended to the nonhuman creation. By doing

\footnotetext{
${ }^{589}$ Ibid., 135.

590 Ibid., 212.

${ }^{591}$ McFague, Super, Natural Christians.

${ }^{592}$ Her earlier theology of embodiment goes against what she believes to be a lack of Western Christian theology that can minister not just to the spirit, but to the body. McFague, "Human Beings, Embodiment, and Our Home the Earth."

${ }^{593}$ McFague, Super, Natural Christians, 10.
} 
this, she seeks to extend a theological model that goes beyond a subject/object dualism. ${ }^{594}$ For, as with much of her other writings, she insists, "the basic model in the West for comprehending self, world, and God has been subject versus object." ${ }^{, 595}$ In this new subject/subject relationship, she writes, "Christian practice, loving God and neighbor as subjects, as worthy of our love in and for them, should be extended to nature." ${ }^{\circ 96}$ This response to Western anthropocentrism focused on individuality replaces it with ecocentrism, focused more on relationship of all creatures. ${ }^{597}$ In anthropocentric thought, there is little to no role given to creation as a subject. It has been relegated to being a passive object in the cosmic order. In this sense, ecological God-talk is a sort of postcolonial discussion, learning to talk about the earth from the perspective of the ones who have colonized it. Humans must extend towards nonhuman life subject/subject status. As evidenced in this text, the two most shaping influences in her theology are process theology and feminist epistemology. ${ }^{598}$

McFague's Life Abundant (2001) offers an extended in-depth examination of her comprehending of the Spirit in her own theological work. ${ }^{599}$ In particular, chapter 8 , entitled "Life in the Spirit," focuses on the hidden nature of God's Spirit in the world. McFague writes, "Christians believe the world is hidden in God...this is the same as

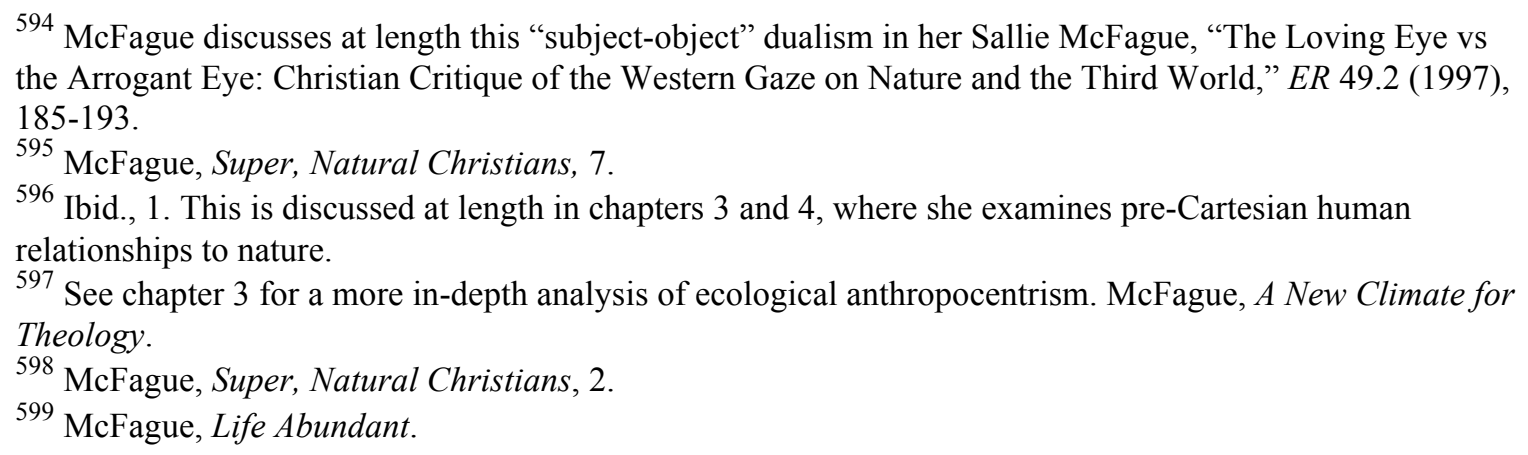
the Arrogant Eye: Christian Critique of the Western Gaze on Nature and the Third World," ER 49.2 (1997), 185-193. 
saying that human existence takes place within God's Spirit." ${ }^{\circ 60}$ This omnipresent Spirit lives amongst all things and gives connectivity to all beings within God's body. Living the Spirit-filled life is openness to this connectivity as conversant with both John Woolman (Quaker) and Dorothee Day (RC), models of people who lived Spirit-filled lives in connectivity to the hidden Spirit in the world. The sociological nature of the Spirit is seen here as the presence of God to accommodate humans change their assumptions and beliefs about the world and in the world. But her clarity about the Trinity raises many questions. For example, she comments, "The Trinity is certainly about God, but just as important, it is about God and the world; it is a way of talking about God's transcendence and immanence in relation to the world."601

McFague's A New Climate for Theology (2008), nearly seven years after LifeAbundant, deals with many issues relating to her ecotheology and attempts to "bring the church back down to earth." 602 Within, McFague offers accommodating data regarding the ecological crisis along with statistics by the IPCC and other research collected by McFague. ${ }^{603}$ But McFague takes a positive stance regarding the overall efforts of saving earth by governmental policy change, commenting "governments must force us to change the way we live, but we must elect legislators who will create the necessary regulations." ${ }^{604}$ But in the end, what is unacceptable is our unwillingness to act. This is where she speaks of the motivation to act. ${ }^{605}$ What makes human beings want to bring

\footnotetext{
${ }^{600}$ Ibid., 182.

601 Ibid., 141.

${ }^{602}$ McFague, A New Climate for Theology, 32.

603 Ibid., esp. chap. 1.

${ }^{604}$ Ibid., 24-25.

605 Ibid., 24.
} 
change? Eventually, she contends, with others, that the ecological problems our earth faces are largely theological roadblocks. She argues that the vital questions to global warming are who God is and who we are. ${ }^{606}$ Identity plays a massive role in ecological living. This is a church that has forgotten its identity in the world. Citing the twentiethcentury French mystic Simon Weil, she suggests the catholicity (wholeness) of the Christian message is lost unless it includes all of creation, what she calls "ecological catholicity. ${ }^{607}$

Finally, almost certainly the most substantive pneumatological approach by McFague on the relationship of the Spirit to ecotheology and the ecological crisis is chapter 9 of A New Climate for Theology, inspired by Gerard Manley Hopkins's poem "God's Grandeur." ${ }^{608}$ In humility McFague claims that theology, even her own, has neglected the Spirit up until "fifty years ago." ${ }^{609}$ She admits a deficiency in her own constructions, writing, "Even in my own writing, I disparage the 'spirit' metaphor as 'amorphous, vague, and colorless,' 'ethereal, shapeless, and vacant,' concluding that 'Spirit is not a strong candidate for imaging God's sustaining activity.' But how wrong I was. I should have known better." ${ }^{\circ 10}$

McFague draws from Hopkins 1877 poem, critical of Western industrialism that separates humans from nonhuman beings, seeing the Spirit as the indwelling presence

\footnotetext{
${ }^{606}$ Ibid., 30-32.

${ }^{607}$ Ibid., 34. Weil originally wrote, "We have to be catholic, that is to say, not bound by so much as a thread to any created thing, unless it be to creation in its totality." For original text, see Simone Weil, Waiting for God (New York: Putnam, 1951), 98.

${ }^{608}$ See McFague's chapter "The Dearest Freshness Deep Down Things: Some Reflections on the Holy Spirit and Climate Change," in McFague, A New Climate for Theology, ch. 9.

${ }^{609}$ Ibid., 114.

${ }^{610}$ Ibid. For original citing, see McFague, Models of God, 169-171. McFague claims that her next text sees the importance of the model of the Holy Spirit. McFague, The Body of God, $141 \mathrm{ff}$.
} 
within all in the midst of hopelessness such as our own. ${ }^{611}$ God's Spirit, the sustaining force, or the "dearest freshness deep down things," keeps life continuing because of her life is not our own. Taking Hopkins cue, McFague imagines the Spirit is a sort of electricity that "charges" all of creation. ${ }^{612}$ In her own words, all creation then lives within God by the Spirit being in the world. This is, ultimately, a reflective kind of Christian mysticism. ${ }^{613}$ And when God is envisioned in all of creation, hope emerges to care for it. McFague argues that this is the task of all humanity, birthed by God's Spirit, regarding hope in the midst of the ecological catastrophe. ${ }^{614}$ And we can have hope because God's Spirit lives in all entities, incarnate in creation. This is the basis of our hope. And eventually, in time, this hope will lead us to "radical change."615

\subsection{Mark Wallace's "Wounded Spirit”}

Our final conversation partner now comes into focus: Mark I. Wallace. Dr. Wallace, professor of religion and theology at Swarthmore College (Pennsylvania), received his $\mathrm{PhD}$ in theology from the University of Chicago in $1986 .{ }^{616}$ Since then, his primary research ventures have consistently developed the growing intersections between Christian theology, critical theory, late modern philosophy, and environmental studies.

Furthermore, Wallace is a leading scholar in the philosophical and theological trajectories

\footnotetext{
${ }^{611}$ The original poem is found at McFague, A New Climate for Theology, 113.

${ }^{612}$ Ibid., 115.

${ }^{613}$ McFague defines Christian mysticism as "seeing God in all things and all things in God." Ibid., 117.

${ }^{614}$ Ibid., 122.

615 Ibid., 125.

${ }^{616}$ Wallace's website offers a helpful biography which including a CV, academic biography, and helpful links to many "green" websites that play into his contribution to the field. http://www.swarthmore.edu/Humanities/mwallac1/, (accessed June 9, 2009).
} 
of Paul Ricoeur and René Girard ${ }^{617}$ As a self-pronounced "theologian in a secular college," Wallace has exuded a dialogical balance between the academy and the life of Christian faith as evidenced by his prolific writing in both sectors. ${ }^{618}$ Although an active scholar in a number of fields, it is his theology of the Spirit and earth that has undoubtedly been his most important contribution to the academic community—and most certainly for our purposes here.

What does theology, or religious thought in general, have to do with the earth, Wallace asks? He contends, despite clear and present challenges, there remain two core "baseline convictions" present in every central religious concept of nature with respect to the sacred. Primarily, all religious ecologies have a belief in a sacred presence- "God, the Other, the One"- - holding all of life and living beings in a connective life-sustaining orbit. For Wallace's own purposes, he continuously pursues advances on a pneumatological basis illuminating a belief in the Spirit of God to be this life-giving presence. His second "baseline conviction" is a view of the sacred in the entire natural order leading to an "ethical ideal" of healing for all communities of endangered species ${ }^{619}$ That is, an ecotheology of creational healing will always emerge primarily

\footnotetext{
${ }^{617}$ For a helpful engagement and synthesis of Ricoeur's academic career, see Wallace's introduction to Paul Ricoeur and Mark Wallace, Figuring the Sacred: Religion, Narrative, and Imagination (Minneapolis: Fortress, 1995), 1-32. As well, for a more pointed look at Wallace's engagement with René Girard, see his Mark Wallace and Theophilus Smith, eds., Curing Violence (Sonoma: Polebridge Press, 1994).

${ }^{618}$ Wallace, Fragments of the Spirit, ix. His own academic context, Swarthmore, maintains a very strong Quaker heritage. Wallace offers, to borrow his terminology, a "meta-critical" approach to the Christian tradition. This allows him the balance of detecting problems within Christian theology while eventually returning to its beauty and purpose for everyday life in practice. See his introduction to Wallace, The Second Naiveté: Barth, Ricoeur, and the New Yale Theology (Macon: Mercer University Press, 1990). ${ }^{619}$ Wallace's introduction to the topic of ecological religious thought includes these two ideas prevalent within religious ecology. See http://www.swarthmore.edu/Humanities/mwallac1/mark.orientation.html, (accessed June 9, 2009).
} 
from a view of the sacred Spirit. It is this view of the sacred which shapes ecological practice. Christianity, Wallace believes, must renew this view.

Wallace's earliest work engages the philosophical/theological traditions of Karl Barth, Paul Ricoeur, and René Girard. These voices, as we will encounter, will continue to shape Wallace's thought throughout his ecotheological ventures. Wallace's three main philosophical texts have offered an analysis of the traditions of Barth, Ricoeur, and Girard. First, Wallace's The Second Naiveté (1990) proposes a comparative reading of Barth, Ricoeur, and the New Yale Theology (Frei, Lindbeck, Holmer, and Kelsey). ${ }^{620}$ Here, Wallace ultimately suggests that the three find hermeneutical common ground in a framework that goes beyond the historical/critical "realist" approach to hearing God's word in the words of the diverse testimonies of the biblical witness. ${ }^{621} \mathrm{~A}$ second work that parallels this to some degree is his edited volume with Theophilus Smith, Curing Violence (1994) ${ }^{622}$ In Curing Violence, Wallace and Smith attempt to integrate a Girardian view of violence and desire — known as "mimetic desire" — to both religious and cultural life as the cure of violent interaction. ${ }^{623} \mathrm{~A}$ final philosophical work, Figuring the Sacred (1995), is an edited volume of Ricoeur's writings. ${ }^{624}$

Overall, Wallace, unlike many other seemingly apologetic ecowriters in theological circles, is optimistically honest about the potential of the Christian vision for earth care. Wallace appears at the same time reticent to abdicate the blame for the world

\footnotetext{
${ }^{620}$ Wallace, The Second Naiveté.

${ }^{621}$ Ibid. Wallace continues this theme in a later article, Mark Wallace, "From Phenomenology to Scripture? Paul Ricoeur's Hermeneutical Philosophy of Religion," MT 16.3 (2000), 301-313.

${ }^{622}$ Smith and Wallace, Curing Violence.

${ }^{623}$ Wallace and Smith, eds., Curing Violence.

${ }^{624}$ Ricoeur and Wallace, Figuring the Sacred.
} 
crisis on other religions, cultures, or people groups. Although readily acknowledging the possibility that Christianity can be wholly antiecological, Wallace forwards the notion of repentance as a way to engender changed ecological practice. ${ }^{625} \mathrm{He}$ ultimately posits that a overwhelming part of the problem must be laid at "our consumption-intensive habits" of Western society; habits which continue to be perpetuated regardless of consistent academic and popular awareness that they are unsustainable. Wallace calls this lifestyle "ecocide." ${ }^{626}$ Comparing Christianity's role to caring for the earth with his deathly allergy to bee stings, Wallace sees the good and bad in the promise of an ecological Christianity. Illustrating that homeopathy ("like treats like") treats bee allergies with acute increments of bee venom over time, Christianity is both the main problem, but it is also the main solution. ${ }^{627}$ What is Wallace's approach to this solution? With these two vital convictions in mind, let us engage Wallace's main texts to discern his view of the Spirit as it pertains to the earth, its brokenness, and healing.

Let us examine Wallace's ecotheology. In a 1993 article, Wallace writes, "I maintain that the most adequate response to this debate (of ecotheology) lies in a recovery of the Holy Spirit as a natural, living being who indwells and sustains all lifeforms. ${ }^{"} 628$ These words are paradigmatic for Wallace throughout his ecotheology. Regarding the Spirit who heals, Wallace writes, "Like the brooding water spirit [sic] in Genesis, the dove in the gospels, or the tongues of flame in Acts, the Spirit reveals itself

\footnotetext{
${ }^{625}$ For instance, see the introduction to chapter 1 in Mark Wallace, Finding God in the Singing River: Christianity, Spirit, Nature (Philadelphia: Fortress, 2005).

${ }^{626}$ Ibid., 27, 30. Wallace compares the addictive human lifestyle towards the earth with alcoholism, a condition which Carl Jung categorizes as a spiritual addiction in his psychological endeavors.

${ }^{627}$ Ibid., 31.

${ }^{628}$ Mark Wallace, "The Wild Bird Who Heals: Recovering the Spirit in Nature," TT 50.1 (1993), 13-28 (14-15).
} 
in the biblical literatures as a living being who works to create, sustain, and renew humans and other kind in solidarity with one another." ${ }^{\circ 29}$ This pneumatic point of entrance offers Wallace a framework for his ecotheology. By far, in terms of importance and breadth of readership, Wallace's seminal Fragments of the Spirit: Nature, Violence, and the Renewal of Creation (1996) offers the most developed contribution of his pneumatological theology of the earth. ${ }^{630}$ Claiming the text to be more rhetorical than philosophical, Wallace sidesteps the replayed philosophical debate regarding the ontological existence of the Spirit assuming its presence throughout creation. ${ }^{631}$ Weaving biblical hermeneutics, philosophy, and experiential narrative, Wallace extends his overall thesis that "the Spirit is the power of life-giving breath (rûach) amongst the cosmos who continually works to transform and renew all forms of life — both human and nonhuman." ${ }^{632}$ Throughout Fragments of the Spirit, the creativeness of his approach is comparatively unique. Divided into two sections, Wallace seeks first to bring into conversation a number of contemporary religious thinkers and late modern theorists and philosophers for his purposes. ${ }^{633}$ Subsequently, Wallace demonstrates the life-giving power of this down-to-earth Spirit both for theology and earth-praxis. ${ }^{634}$ It is within section two where he offers his most readily accessible ecopneumatology.

\footnotetext{
629 Ibid., 15.

${ }^{630}$ Wallace, Fragments of the Spirit.

631 Wallace acknowledges this prejudice at the beginning of his text. Ibid., 2.

632 Ibid., 1. Wallace continues, "[T] he purpose of this book is to contemporize the ancient appellation by reenvisioning the Holy Spirit as God's invigorating presence within the society of all living beings."

633 In particular Wallace includes the voices of Søren Kierkegaard, Paul Ricoeur, Schubert Ogden, René Girard, Jürgen Moltmann, Ronald Thiemann, and Richard Swinburne.

${ }^{634}$ Similarly, he gives attention to Friedrich Nietzsche, Jacque Derrida, Michel Foucault, Julia Kristeva, Emmanuel Levinas, and Richard Rorty.
} 
A number of important themes and motifs emerge from a reading of Fragments of the Spirit. First, central to Wallace's ecopneumatology is a view of the Spirit that transcends a simple stagnant presence. Rather, the Spirit in creation also has a semiotic value - as "a potent ecological symbol." ${ }^{635}$ That is to say, Wallace argues, the Spirit is both a symbol and presence of God in creation. With deference to Western metaphysics, this symbolic omnipresence leads to an "ecological pneumatology" that forces humans to no longer imagine God's Spirit as being "out there" but quite near as humans encounter breath, wind, fire, and the like. ${ }^{636}$ Ontologically speaking, continuing to "hover" (Gen. 1:2) over chaotic creation, the Spirit brings order and life out of chaos as "a healing lifeforce that engenders human flourishing as well as the welfare of the planet." ${ }^{637}$ This breath-presence is at the very core of life on earth, says Wallace, which ultimately corrects a post-Hegelian metaphysic that often caricatures the Spirit. This ethereal Hegelian Spirit is in the words of Arthur Cohen, as "bodiless, passionless, and unearthly. ${ }^{938}$ In his corrective theology, Wallace reminds us that the Spirit continues to be embodied in natural symbols throughout the biblical narrative (breath, wind, fire), exemplifying a semiotic dynamic whereby the Spirit is shown not only in creation but part of the very fabric of its being. Therefore, the Spirit's fleshly and earthly experience brings her down to earth, so to say. Nature does not simply provide God-symbols with which to speak of himself; rather, he sets up camp within it embodying the symbols themselves.

\footnotetext{
${ }^{635}$ http://www.swarthmore.edu/Humanities/mwallac1/mark.orientation.html, (accessed June 9, 2009).

${ }^{636}$ He uses "ecological pneumatology" to differentiate from Western metaphysical understandings of the Spirit. Wallace, Fragments of the Spirit, 2.

${ }^{637}$ Ibid.

${ }^{638}$ Arthur Cohen, Thinking the Tremendum: Some Theological Implications of the Death-Camps (New York: Crossroad, 1988), 4.
} 
Second, we discover that Wallace portrays the Spirit as playing an integral role as the restorer of broken relationship between both humans and human/nonhumans. Wallace points out an ontological problem with earthly existence: all human beings (and nonhumans) live in opposition to one another for one reason or the next. ${ }^{639}$ This problematic relational chasm pervades creational, human, and ecological cultures. In an effort to resolve this, Wallace turns to the Girardian notion of "the Other." ${ }^{" 640}$ With a formal academic background in philosophy, Wallace utilizes both Emmanuel Levinas's Abrahamic Akedah discourse and René Girard's scapegoat theory to suggest that "attuning oneself to the Spirit's promptings to care for the other is the beginning of religious life and thought." ${ }^{\text {"641 }}$ In the same way Girard pointed to "scapegoats"- those individuals a society deems the main thrust of such society's ills (i.e. Martin Luther King Jr., Jesus, Gandhi) — Christ comes to reconcile scapegoats to others. Ultimately, for Levinas, Girard, and Wallace, this is a central, if not the point of religious living and praxis. Religious life, therefore, is open to the Spirit's healing power in all of these interrelationships - especially in the context of reconciling those at the center of society and those on the fringe (scapegoats). Wallace's exegesis of the Girardian view of mimetic desire and scapegoating point to clues of the state of human sin, finding fruition in interhuman violence, creatively making room for the Spirit's role in healing this violence

\footnotetext{
${ }^{639}$ Girard concludes that the scapegoat, which is "the many against the one," is ultimately a hermeneutical model for the scandal of the cross of Christ. Human desires ultimately lead to their turning towards one another in violence. In ecological terms, Wallace seems to suggest that humans have turned this sort of barbaric energy towards creation.

${ }^{640}$ For a more full-bodied extrapolation of Girard's view of violence and "the other," see Wallace and Smith, eds., Curing Violence.

${ }^{641}$ Wallace, Fragments of the Spirit, 91. For an elongated version of Wallace's development of Levinas and Girard's thought regarding "the Other," see Wallace, "From Phenomenology to Scripture?" In terms of the Spirit's role between creatures, I am reminded of John Taylor's classic exposition of the Spirit "inbetween," see Taylor, The Go-between God.
} 
towards "the Other." This remaining chasm between human beings and nonhuman entities is what the Spirit seeks to bind.

Third, Wallace couples this view of human/nonhuman ontological opposition with Walter Wink's classic study on the NT powers. This will culminate into what Wallace argues are three primary characteristics of the Spirit's work in the world today. ${ }^{642}$ Firstly, Wallace writes, "in the Gospels, the Spirit is portrayed as the divine agent of political and cultural subversion who inverts the normal power relations amongst society." ${ }^{643}$ That is, the social fabric of society finds its egalitarian culmination from the Spirit who seeks to deliver life to all creatures, great and small. We begin to see the social implications of Wallace's ecopneumatology in reorganization around the Spirit, not human perceptions of creaturely importance. Wallace's second point begins with "the threat of violence against the bearers of the Spirit's advocacy for victims." ${ }^{644}$ Here, the Spirit acts on behalf of not only living humans but also living beings, which experience the torment and torture of bondage. The Spirit is on the side of the oppressed. And thirdly, "the presence of Spirit-filled countercommunities forged by persons who respect difference and renounce the use of violence to suppress difference." ${ }^{645}$ Where Levinas highlighted the imperative to care for "the Other," the Spirit makes space for respect towards creatures that are very different. Wallace's view of the Spirit among creation will always seek to "blur the human/nonhuman distinctions" and destroy hierarchical understandings of

\footnotetext{
${ }^{642}$ For Wink's three-part "power" series, see Walter Wink, Naming the Powers: The Language of Power in the New Testament (Minneapolis: Fortress, 1984); Walter Wink, Unmasking the Powers: The Invisible Forces That Determine Human Existence (Minneapolis: Fortress, 1986); Walter Wink, Engaging the Powers: Discernment and Resistance in a World of Domination (Minneapolis: Fortress, 1992).

${ }^{643}$ Wallace, Fragments of the Spirit, 123-125.

${ }^{644}$ Ibid., 125-127.

645 Ibid., 127-128.
} 
creation. ${ }^{646}$ This mixing of categories within the created order is what Wallace later calls "composting." ${ }^{647}$ The Spirit beckons all "Others" into relationship with the remainder of the community of creation. This egalitarian view of the Spirit among creatures challenges modern assumptions of class-distinction between different species of animals, in essence "sowing confusion and disorder" by destroying these lines of separation. ${ }^{648}$

The healing of human and nonhuman relations is remedied by a strengthened pneumatology. Wallace points out that in the history of Western Christianity, the Spirit has been portrayed as having three vital roles: (1) as the Trinitarian economy of the Godhead, (2) as the interior lives of human persons, (3) and as the community of beings within creation. The Spirit acts as the bond of love between the Father and the Son (vinculum amoris), the one who instructs the believer to care for the well-being of the other (interior magister), and the power of the creative God who continues to animate and offer life to all beings in the cosmos (continua creatio). ${ }^{649}$ This Trinitarian model of the immanent Spirit celebrates the life and beauty of creation as an outflow of the love of the Father and the Son. Thus, the Trinitarian Spirit works "to promote intimacy and heal divisions among God's creatures, human and nonhuman. ${ }^{\prime 650}$ Healing, in this way, is

\footnotetext{
${ }^{646}$ Ibid., 6. Wallace points out that René Girard calls this the "muddy mass" and Kristeva calls it the "transitional swarming," which both undermine hierarchical cosmologies. René Girard, Violence and the Sacred (Baltimore: Johns Hopkins University Press, 1977), 51.

${ }^{647}$ Wallace, Fragments of the Spirit, 152.

${ }^{648}$ Ibid., 6.

${ }^{649}$ This three-part distinction is an important one for Wallace. Thomas Oden, Life in the Spirit, vol. 3 (San Francisco: Harper San Francisco, 1992); Wallace, Fragments of the Spirit, 145.

${ }^{650}$ Wallace, Fragments of the Spirit, 146.
} 
seeking to "engender...the unity forged by the erasure of artificial boundaries between the human self and the nonhuman other." ${ }^{951}$

Wallace argues that the reality of a relational Spirit amongst creation is in its relationship with the other two members of the Trinity. ${ }^{652}$ The Spirit then does not just give life but heals life. Wallace reminds us that a biblically informed pneumatology must and should go beyond imagining solely the Spirit's life-giving role. As well, the biblical Spirit must be understood similarly in its judgmental and destructive character within the creation schemata. Just as the Spirit creates, it destroys and judges as well. As the Spirit gives life, the Spirit judges life. Wallace refers to this as "the dark side" of the Spirit, exemplified in the judgment of Ananias and Sapphira in the book of Acts and the Spirit's power and strength giving role with the Judges of Israel in destroying Israel's enemies. ${ }^{653}$ Therefore, ecopneumatology must have two eyes: the creative eye and the destructive eye. As the Holy Spirit broods over creation, it likewise ushers in the storm, the typhoon, and the earthquake in similar fashion. The Spirit therefore judges all false forms of separation.

Interesting implications arise from Wallace's synthesis of pneumatology with biology. Wallace suggests that ecotheology is a reevaluation of the language, views, and assumptions of a society that misunderstands nonhuman creation. Sadly, the normative understanding, says Wallace, is that we either see nature as "God's good creation to be

\footnotetext{
651 Ibid.

${ }^{652}$ Wallace, Finding God in the Singing River, 40-56. He says the "Spirit is the power of reciprocity, communion, mutuality, oneness, unity." Ibid., 40.

${ }^{653}$ Wallace, Fragments of the Spirit, 3. Wallace argues where this "dark side" is discussed is often in feminist pneumatology and post-holocaust Jewish thought. For an example, see Phyllis Trible, Texts of Terror: Literary-Feminist Readings of Biblical Narratives (Philadelphia: Fortress, 1984).
} 
enjoyed and nurtured by all living beings, human and nonhuman," or nature is nothing more than "dumb matter" to be controlled and lorded over by humanity. ${ }^{654}$ It is this particularly limiting dualism that has led to the sacralization of the destruction and exploitation of God's creation. As mentioned, Wallace maintains "the most adequate response to the current crisis lies in a recovery of the Holy Spirit as a natural, living being who indwells and sustains all life-forms." ${ }^{965}$ Sadly this vision is lost on a Christian tradition reactive to pantheism and paganism. This fear has led to a Christianity that has minimized their Spirit/creation theology out of fear paganistic methodology will creep in. The result of this is a misunderstanding of panentheistic thought to be differentiated from pantheism. ${ }^{656} \mathrm{He}$ argues that the panentheistic position has in essence been the traditional position of the Christian faith as evidenced, for instance, in the doctrine of transubstantiation. ${ }^{657}$ Here, God becomes the bread. This explains why Wallace calls the Spirit of God incarnate the carnal Spirit, "the Lord, the Giver of Life."

Again, this cultural critique is often fleshed out in biocentric thought, or the creaturely egalitarian approach. Wallace dubs this a "Muir-like, Job-like ecological pneumatology." ${ }^{659}$ Reactive to Western creation paradigms which raise the

\footnotetext{
${ }^{654}$ Wallace, Fragments of the Spirit, 135.

655 Ibid., 136.

${ }^{656}$ Panentheism is, as defined by one scholar, as " $[\mathrm{t}]$ he belief that the Being of God includes and penetrates the whole universe, so that every part of it exists in Him, but that His Being is more than, and is not exhausted by, the universe." Frank Cross and Elizabeth Livingstone, eds., The Oxford Dictionary of the Christian Church (Oxford: Oxford University Press, 1985), 1027. Wallace makes the statement that the "Spirit and earth are inseparable and yet at the same time distinguishable." This appears to be congruent with the idea of panentheism, God in but separate from creation. Wallace, Fragments of the Spirit, 136.

${ }^{657}$ Wallace, Fragments of the Spirit, 143-144.

${ }^{658}$ Wallace, Finding God in the Singing River, 32. Wallace reminds us that the Nicene Creed in 381 C.E. offers us a model of the Spirit as life-giving in its very nature.

${ }^{659}$ Wallace, Fragments of the Spirit, 168. For an interaction with Job's emerging ecotheology, see ibid., 158-162.
} 
anthropocentric (what Wallace calls "humanism") ${ }^{660}$ flag of victory above all other species, Wallace rightly highlights a biblical motif that is critical of the Sitz im Leben of both Near Eastern and Western cosmologies that place humanity at the center of the creation story. Anthropocentric cosmology is therefore a practical and psychological challenge to ecological living in that it assumes humanity's prevenient importance before any other creation. ${ }^{661}$ Wallace counters this with biocentrism as being a key element of late modern thought and healing of a broken creation. ${ }^{662}$ By deconstruction, must we assume that it is human agency that is responsible for the care of the earth, and if not, who decides this? Here Wallace's uniqueness is evident, for he claims that a significant segment of his effort is to comprehend the Spirit not theocentrically or anthropocentrically but biocentrically within nature. ${ }^{663}$ Echoing McFague's panentheistic construction, yet simultaneously critical, the Spirit lives and breathes alongside and within all worldly creatures. Nevertheless, preempting his potential critiques that would follow, he makes clear that this assist by McFague is not equivalent to a natural theology (so as to not disappoint Barth), whereupon humans can have knowledge of God apart from revelation. At one point Wallace comments that if God made Adam and Eve from dust, spoke through a donkey, delivered Jonah through a big fish, and appeared in a dove,

\footnotetext{
${ }^{660}$ Wallace, Finding God in the Singing River, 83. Here he follows Ehrenfeld in his David Ehrenfeld, The Arrogance of Humanism (Oxford: Oxford University Press, 1978).

661 This is his general thesis in chapter 4, "Green Spirituality and the Problem of Humanism," in Wallace, Finding God in the Singing River, 81-96.

${ }^{662}$ Wallace defines biocentrism as the belief that "all life-forms possess intrinsic value as enfleshed members of a common biotic order, and that non one species, including the human community, enjoys natural priority over any other species." Wallace, Fragments of the Spirit, 32-33.

663 Ibid., 138.
} 
we can no doubt assure ourselves that God can speak through natural process the same as a prophet would. ${ }^{664}$

Wallace carefully attempts to not equate God with creation. Rather, he devises a view of immanence, making space for the suffering of God along with his handmade creation. Again, Wallace argues the late modern scene is promising and gives pneumatology a solid grounding on which to build in a rapidly changing philosophical scene. ${ }^{665}$ In a later work, Wallace speaks of a revisionary paganism in response to a Spirit that is often overly ethereal in theological imagination. Wallace contends in a way that paganism is somewhat of a healthy corrective of Western monotheisms. He points to such societies as the Nordics, Teutonic, and Celtic religions to find nature views of the sacred forest that naturally builds God's presence into life forms. ${ }^{666}$ At times he calls for what he terms revisionary paganism. This revisionary paganism will "seek to reverse centuries of Western Christian hostility toward nonhuman life by again reenvisioning all of creation as a virtual sacred grove." 667

There are similar linguistic challenges that Wallace seeks to address. He suggests that the translation of the Holy Spirit as Holy Ghost has directly shifted our conceptual

\footnotetext{
${ }^{664}$ Wallace, Finding God in the Singing River, 3.

665 Wallace argues that late modern thought culminates in five themes: erasure of self, deprivileging of metaphysics, breakdown of metanarratives, revalorization of nature/biocentrism, and the failure of theodicy. Wallace, Fragments of the Spirit, 22-34.

${ }^{666}$ Wallace, Finding God in the Singing River, 13-18. Wallace differentiates paganism from Satanism on many fronts, illustrating a pagan tendency to have negative perspectives towards Satanism feeding off Christianity's polemic against the devil. Neopaganism therefore, in Wallace's view, creates communalism with nature and is a return to relational integrity with the land. See his section on "The Trinity and Paganism," in ibid., 43-46.

${ }^{667}$ Wallace, Fragments of the Spirit, 144. He later calls this the "biophilic approach."
} 
model of God's invisible presence in creation to a "spook," "unreal," and "immaterial." This is no ghost, Wallace reminds us. But rather, "The Holy Spirit is a wholly enfleshed, avian life-form made up of the four primitive elements — wind, water, fire, and earththat are the key components of embodied life as we know it." ${ }^{\prime 69}$ These four images drive our fleshly vision of the Spirit. As earthen images, the Spirit establishes himself as the dove bringing back a twig back from new lands and baptizes Jesus in the gospels. ${ }^{670}$ As air, the Spirit is the fresh blowing power of enabling breath that gives life away to all creatures, as well as playing the role of the prophetic power that enables salvation in its residents. ${ }^{671}$ As water, the Spirit gives salvific life to all who chose to drink. ${ }^{672}$ And finally, as fire, it is the power of the judgment of God and the progenitor of the Spirit's prophetic calling in the world. ${ }^{673}$

Wallace speaks of the "Wounded Spirit." Because the Spirit and earth are inextricably intimate in relationship, causing pain for the divine Spirit. For such a connected comprehension of God in nature and nature in God, Wallace writes, "If Spirit and earth mutually indwell each other, then God as Spirit is vulnerable to loss and destruction insofar as the earth is abused and despoiled." 674 The vulnerable God rarely fits into a theological construction where God is so far above creation that its affairs are beyond God's care unless it deals with those of humanity. For when "the waters and

\footnotetext{
${ }^{668}$ Wallace, Finding God in the Singing River, 7-8.

${ }^{669}$ On the same page, he writes of the Spirit as a "sacred animal". Ibid., x.

${ }^{670}$ Gen. 8:11; Matt. 3:16; John 1:32. Ibid., 36.

${ }^{671}$ Ibid., 36-37. What Wallace calls the "vivifying breath," he draws from Genesis 1:2 and Psalms 104:2930. For the prophetic nature of the Spirit, Wallace points to Judg. 6:34; John 3:6-8; Acts 2:1-4.

672 John 3:1-15; 4:14; 7:37-38. Ibid., 37.

${ }^{673}$ Matt. 3:11-12; Acts 2:1-4. Ibid., 37-38.

${ }^{674}$ Wallace, Fragments of the Spirit, 138, (italics mine).
} 
winds and birds and fires will not be regarded only as symbols of the Spirit but rather as sharing in her very being as the Spirit is enfleshed and embodied through natural organisms and processes," theology must be freshly opened to the possibility of a God that is very open to pain and suffering with creation ${ }^{675} \mathrm{He}$ calls this the "Wounded Spirit." We see this for instance in his "The Wounded Spirit as the Basis for Hope in an Age of Radical Ecology," where Wallace suggests this "Cruciform Spirit" suffering with creation being dependent on his theology of the economic Trinity offers a pneumatology of strong earthly implications. ${ }^{676}$ Wallace writes, "Jesus suffers on the cross for the sins of the world; the Spirit in the earth suffers the despoilment of the world." ${ }^{.677}$ This arises from the unified Godhead; the Spirit who suffers in the same way Jesus did on the cross for the earth. It is this unified Godhead that is unified with suffering creation. As does Edwards, citing Basil, Wallace points out the historical Christian comprehension of the Spirit was always in terms of "communion, mutuality, and the overcoming of divisions. ${ }^{9678} \mathrm{He}$ contends the Latin understanding of the Trinity is pregnant with the idea of mutual love between the Father and Son. Making use of the perichoretic vision of the patristics to include the creation in the dance. ${ }^{679}$

Finally, we turn our attention to Wallace's most recent ecopneumatological text which leans heavily on the "deep ecology" movement, Finding God in the Singing River

\footnotetext{
${ }^{675}$ Wallace, "The Wild Bird Who Heals," 15.

${ }^{676}$ Mark Wallace, "The Wounded Spirit as the Basis for Hope in an Age of Radical Ecology," in Christianity and Ecology, eds. Dieter Hessel and Rosemary Ruether (Cambridge: Harvard University Press, 2000), 51-72. This same topic is discussed in his Mark Wallace, "The Green Face of God: Christianity in an Age of Ecocide," CRC 50.3 (2000), 310-331.

${ }^{677}$ Wallace, Finding God in the Singing River, 123-125. See the theme of "wounded Spirit" again in Wallace, "The Wounded Spirit as the Basis for Hope in an Age of Radical Ecology."

${ }^{678}$ Wallace, Fragments of the Spirit, 6.

${ }^{679}$ For a helpful understanding of the "perichoretic dance," see Catherine LaCugna, God for Us: The Trinity and Christian Life (New York: Harper, 2006).
} 
(2005). ${ }^{680}$ This text is largely an expanded edition of a 2000 article. ${ }^{681}$ It comes at a time when the concept of "nature" is under debate in a late modern ethos. ${ }^{682}$ Singing River, a very personal, yet theologically engaging account of his experience of the divine in creation, examines the suffering of God within creation. Here, he seeks to uncover in Christian tradition, what, he eventually argues, is through and through an "earth-centered, body-loving religion." ${ }^{983}$ Wallace summarizes a crucial perspective of a Christian theology of the earth in the incarnation of Christ. This offers a model of God's presence in the flesh where God is truly intertwined with the flesh, blood, and chlorophyll of earth. Sadly, Wallace points out, this point has been lost to modern Christians as God quickly becomes a sky God who is not known "in any palpable sense." ${ }^{684}$ Again, discussing theology of revelation (can God speak through nature?), theology of creation (how is God related to the created order?), but most importantly for us a pneumatology of creation (how is the Spirit upon the earth?), he arrives at a vista which gives a full-fledged account of the Spirit in the creation landscape. Along the way to recovering a vision of the earthen Spirit, he also makes the attempt to recover the Spirit's female identity. ${ }^{685}$

We now conclude our analysis of Wallace's work. In closing, it is interesting to note that Wallace contends that one exception to these earth-unfriendly trends is in that of PC traditions who theologically and practically "encounter the work of the Spirit in their

\footnotetext{
${ }^{680}$ Wallace, Finding God in the Singing River. Furthermore, on the relationship with "deep ecology" philosophy, see the helpful ibid., 18-22.

${ }^{681}$ Wallace, "The Green Face of God."

${ }^{682}$ For Wallace's discussion on the relationship between green theology to a late modern onslaught of legalistic deconstruction with particular mention to pneumatology, see Wallace, Finding God in the Singing River, 97-120.

${ }^{683}$ Ibid., 6.

${ }^{684}$ Ibid., 4.

${ }^{685}$ Ibid., 9.
} 
everyday lives. ${ }^{968}$ Through their experience in Spirit baptism, PC believers touch the Spirit's power in life-altering ways. While Wallace does identify himself with the PC tradition, he observes a surprising power in the Pentecostal view of the Spirit in redeeming the Spirit's role in the economic Trinity and ultimately a renewed ecological ethic based on the Spirit. Yet what is lost in the search for the Spirit, especially in Pentecostal traditions, are the "traces of the Spirit's presence in the world around us." Wallace suggests this has guided Western philosophy towards a view of the Spirit that plays a subtle role in the cosmos, best illustrated in Plato's vision where the physical body is imagined as the "prison house" and "tomb" of the soul/spirit. The goal therefore becomes release from this tomb, similar to Origen's self-inflicting castration at the age of twenty in order to fulfill his literalistic understanding of Christ's words in Matthew 19:12 regarding eunuchs. ${ }^{688}$ And as we look back, Wallace makes the case, Augustine and the Western tradition is largely to blame for this bifurcation of Spirit and nature.

\subsection{Summary and Reflection}

Now that we have deeply engaged our three dialogue partners-Denis Edwards, Sallie McFague, and Mark Wallace-it is important that we discern their overall value for an emerging Pentecostal ecotheology and ecopneumatology. We set out in this chapter with three main goals in mind. First, to engage the overall ecotheological expression of each dialogue partner. Then, secondly, to focus more on their theology of the Spirit in regards

\footnotetext{
${ }^{686}$ Ibid., 6-7.

${ }^{687}$ Ibid., 7.

${ }^{688}$ Matt. 19:12 reads, "making themselves eunuchs for the sake of the Kingdom of God." For further discussion on this, see ibid., 34 .
} 
to their ecotheology. These two tasks have been completed. Now, thirdly, it is important we offer critiques of each dialogue partner and more importantly offer suggestions for our construction of a Pentecostal ecopneumatology.

\subsubsection{Reflecting on Denis Edwards's "Biocentric Spirit"}

A number of important points emerge from a reading of the work of Denis Edwards. To begin with, and very important to our study, Edwards rightly discerns that ecotheology (or lack thereof) will inevitably be shaped by the life and times of the ecotheologian. ${ }^{689}$ For instance, ecotheology in the times of Basil was not ecotheology. Rather, it was part and parcel of a greater conversation regarding koinonia theology, shaped by a patristic struggle with the paradox of the Spirit within the economic Trinity. For Basil, ecotheology was a Trinitarian conversation. In his own setting, Basil did not yet understand what the ecological crisis or White's challenge to Christian ecological ignorance were. Basil was a child of his times. And, clearly, so is Denis Edwards. For Edwards, an ecotheologian in his own time synthesizes a Christian theology with evolutionary biology and scientific paradigms.

This brings us to both a critique and praise of Edwards's comprehension of historical ecotheology and the Spirit in creation. Simply put, a Pentecostal critique of Edwards's overall methodology will be his assumption of both evolutionary theory and a scientific worldview. Yet while critiquing his methodological preference, Wallace unintentionally brings to the forefront of our dialogue a key point Pentecostal theology will be forced to address: What should the relationship of Pentecostal theology be to

${ }^{689}$ Edwards, Jesus and the Cosmos. 
scientific and ecological understandings of the world? Edwards rightly exemplifies a theological model open to and critiqued by the scientific community. This is a major, and frankly one of the strongest elements of his methodology. Pentecostal theology has something to learn from him. There must be a level at which theological construction lives openly and humbly alongside the scientific community in a late modern context. For a theology hiding in fear of truth outside its own walls can scarcely consider itself orthodox. Therefore, theology must seek, around every corner, to discover ultimate truth. As Edwards has modeled for us, theology must open itself to being critiqued by science in the pursuit of said truth. If theology is not taking into account climate change as a result of human action, it must ask itself some very important questions. In chapter 2 we briefly outlined the importance of this hermeneutic of humility for theology. That theology interprets its comprehension of truth in constant revision and openness to the Spirit's voice wherever the Spirit speaks. For the story of Pentecost reminds us that the Spirit elusively comes when and where she will (e.g. Acts 2) and falls on outsiders such as Gentile God-fearers (e.g. Acts 6).

For, as we have said, theology must be critiqued by science. Yet, at the same time, theology must likewise critique science in dialogical tension. Pentecostal theological methodology must be in constant tension between these two tasks. Clearly, contemporary Christian ecotheology in the West has largely been molded by the critiques of Lynn White Jr., the ecological crisis, and the perceived ambivalence of Christians to that crisis by the broader culture. As a result, Christian ecotheology in the twenty-first century remains largely apologetic in nature. These ecological critiques should very well shape Pentecostal theology. History has shaped Pentecostal ecotheology in the same way. For 
classic North American Pentecostalism was birthed at a time in American history which was largely framed by the modernist-fundamentalist dispute. This debate dealt primarily, although not entirely, with the issue of evolutionary theory in public pedagogy. In reaction to this, much of Pentecostal history has been shaped by this discussion. With this reaction has come a view of science, including the ecological movement, as being an enemy of theology.

This brings a crucial point. We must remember that in terms of the modernistfundamentalist dispute that shaped early Pentecostalism, science was perceived as the enemy of, not theology, but fundamentalist theology. Science, in this context, did not become the enemy of Pentecostal theology per se. While fundamentalism and Pentecostalism have shared a common history and set of values for some time, the two have unnecessarily been equated. In this setting, I would argue a Pentecostal pneumatology should rightly understand that whatever in science is truthful is an essential testimony of the Spirit. If science teaches us the world is interconnected, it truthfully witnesses to the Trinitarian perichoresis. If ecology teaches us we are living too unsustainable, it truthfully witnesses we must return to the garden of simplicity. What Edwards models for us is a potential framework for Pentecostal ecopneumatology: $a$ dialogical approach of truth-seeking with the ecological movement. And this puts us back into conversation with Pentecostal history. As we began to converse with a Pentecostal theology of creation, it would seem part of the deficient ecotheology we have observed arises from the historical context of earliest Pentecostalism reacting against science. It is for this reason Pentecostals will most likely struggle with Edwards's ecotheology on the basis it assumes an evolutionary biological foundation as the cornerstone of its 
understanding of the "transcendent Spirit." Nonetheless, a Pentecostal ecopneumatology must move forward with this dialogical tension with truth outside itself. On one hand being open to what the ecological community has to offer Pentecostalism, while on the other hand offering back to ecology what a Pentecostal community has to offer.

A level of pneumatological discernment is required in such a dialectical approach as outlined by both Amos Yong and Stephen Parker in their examinations of Pentecostal discernment. ${ }^{690}$ For a Pentecostal theology must critique a scientific comprehension of the world that gives no space to the Creator in creation. If any theory of emergence, be it atheistic evolution or any other, gives no centrality to God in the dynamic creation then theology must respond. Yet, at the same time, Pentecostal theology must be open to what ecologists are warning us as outlined in chapter 1 . One voice (monotheist evolution) must be critiqued while the other (ecology) must be engaged. Only Spirit-led discernment can help in this dialogical tension. For sadly, Pentecostalism has by-and-large lumped ecological findings (e.g. climate change) with those of nontheistic evolutionary theories thus silencing the Spirit's cry to better serve and help restore an oppressed and destroyed creation. Again, a Pentecostal emphasis on discernment will accommodate in this regard.

To be quite sure, in the end, it is here suggested that Edwards's creatively nuanced ecotheology connecting a scientific and theological paradigm for the purposes of developing a more robust Christian view of creation is one of the greatest assists for Pentecostal theology. Edwards's suggestion that the Spirit is constantly helping create space for creation to improve, evolve, and heal should be rightly heard. Pentecostals will

\footnotetext{
${ }^{690}$ Yong, Discerning the Spirit(s); Stephen Parker, Led by the Spirit: Toward a Practical Theology of Pentecostal Discernment and Decision Making, JPTSup, vol. 7 (Sheffield: Sheffield, 1996)
} 
understand this quite well: should not the same Spirit that brings healing to sick humans be also the healer of a sick creation? I would suggest this understanding of the Spirit, as the biocentric force of life as well as the agent that creates openness for creational growth and healing, is not only both interesting and compelling but possibly enlarges a context for Pentecostals to engage and envision the interconnected creation along with a more holistic vision of healing. It suggests a model of Pentecostalism that must strive for a fully integrated and holistic theology of the Spirit beyond "speaking in tongues" and "subsequence" to a theology of cosmic healing.

Finally, Edwards's depiction of the Spirit is one that graces all creation with its presence, protection, and life-giving providence. This grace finds expression in the RC tradition, as Edwards points out in the words of Pope John Paul II who advocated for a theology that saw the Spirit not just in the person of Christ but before in the biblical creation narratives. ${ }^{691}$ Edwards's further utilization of Basil and the Cappadocian fathers is exemplar of defining an historic pneumatology for contemporary purposes, a venture that could not be applauded more. And perhaps, again, this will offer an assist in a more holistic view of healing. Edwards's comprehension of the "transcendent Spirit" that generates space for a creation to grow and improve could accommodate a Pentecostal view of healing. Pentecostals often speak of a God that heals in an "interventionist" sense, stepping into time and space to "fix" a particular problem. Pentecostals should never neglect this view. Nevertheless, perhaps Edwards offers Pentecostals a further refined view of healing where God not only "intervenes" but also more importantly actively creates space for a created being to heal by the natural forces initiated and

${ }^{691}$ Pope John Paul II, The Holy Spirit in the Life of the Church (Boston: St. Paul, 1986), 91. 
continued by the Holy Spirit. It is in this setting that healing, ecologically, sociologically, and cosmically, can find a place in a pneumatological theology most helpful in a Pentecostal context.

\subsubsection{Reflecting on Sallie McFague’s "Hopeful Spirit”}

As with Denis Edwards, a number of themes have emerged from a reading of McFague's expansive works. To begin with, I find McFague's linguistic critique of Western maledominated language to be both a blessing and a curse for her and her readers. On one hand, McFague rightly persuades her audience that any, and all, theological language can inherently be idolatrous. This is surely the case, and no better articulated than in her Speaking in Parables. ${ }^{692}$ This critique is of perennial necessity in theology where God has often been imaged in anthropocentric ways in Western historical theology. But on the other hand, with McFague's late modern critique freshly engaged, we must submit another straightforward and constructive line of questioning.

Is it not true that language is all we have to speak of God? With what else are we to use? From God to Adam's first words in the biblical narrative, language has been the tool given to humanity to communicate with and about God. With words the world was created (Gen. 1), the serpent deceived (Gen. 2), and Adam passed the blame to his wife (Gen. 3). Words are undisputedly powerful. Having said this, PCs have, realizing it or not, offered a practical experience of words that parallels McFague's criticism of literalistic theology. Speaking in tongues (glossolalia), in a sense, offers a linguistic critique of rationalistic and literalistic theological language of which an experiential

\footnotetext{
${ }^{692}$ McFague, Speaking in Parables.
} 
Pentecostalism, and McFague, is rightly dissuaded by. Both McFague and Pentecostals desire to free God from our human linguistic limitations by unlocking theological discourse from the forms in our minds so vigorously desiring to contain him. Pentecostals and McFague also agree that God is, and always will be, greater and more mysterious than theological endeavors. Nonetheless, McFague and Pentecostals do this for different reasons. For Pentecostals, it is often in the name of experience. For McFague, it is in the name of creational, feminist, and linguistic liberation. Interestingly, it is glossolalia that is both the proclamation that language is part and parcel of the necessary toolbox of communication with and about God that humans retain. And it is the witness that language must not always be understandable to be about or in conversation with God. Glossolalia, therefore, is a critique both of language and our Western rationalistic literalistic way of doing theology by offering a linguistic form beyond human rationale. To say this another way, our language must always "keep in step with the Spirit" (Gal. $5: 25)$.

McFague's critical tone rightly offers misgivings about the detriments of a subject-object relationship towards creation in Western philosophy and theology that arises from idolatrous language regarding God. This same subject-object attitude is what has created, in a sense, the bondage for women and nonhuman creation. It is this critique that has largely been the impetus behind a majority of the ecofeminist movement. To begin, I would surrender that McFague, on this point, does not take her critique far enough. For I would suggest that Christian theology for too long has imagined a God that exists in such a way that views humans as his objects. Pentecostals use such language regularly: "God will use you," "God has a purpose for you," and "Jesus is working for 
you." Humans, in this way, are portrayed linguistically as God's tools. Almost certainly, important and essential truths reside in these statements. But they only portray God half way. Perhaps McFague is correct when she asserts that God relates to human beings as beings, subjects - subjects with freedom to hurt and even crucify the Son of this God. This side of God chooses to have a subject-subject (I-Thou) relationship with humanity.

This is not the Christ who only dies for humanity, but dies with humanity. This is the Jesus who cries over the death of a friend (Jn. 11:35) and perishes under the punishment of a wooden cross. This image makes the Christian tradition unique. Human history is the story of people notoriously reflecting and becoming the image of God they create. In the story of Christian theology, Christ experiences tremendous pain. This God risks and becomes vulnerable conjuring powerful ethical and moral implications for the practice of Christian people. ${ }^{693}$ Similarly, a God free from the experience suffering and pain will equally shape the practice of its followers. To put it more simply, an overly transcendent God will always lead to a transcendent people free of pain, sorrow, and disaster. In this context, it comes as no surprise that a human community that treats nonhuman creation as an object in some way shape or form sees themselves as an object to God to be "used." Humanity, largely in the West, has truly transcended the natural world. We are not hurt by it or vulnerable to it because we do not allow ourselves to be hurt by it. But as God opens himself up to subject-subject relationship, so must humans with creation, where humans open themselves to vulnerability.

\footnotetext{
${ }^{693}$ This theological theme of God's vulnerability and riskiness is best examined in William Placher, Narratives of a Vulnerable God (Loiusville: Westminster, 1994).
} 
I would further suggest, and I am sure McFague would agree, that the problem is not entirely linguistic, but imaginative. Too often humans are seen as pawns for God, objects for his use. I would suggest this imaginative attitude has been what has shaped our attitude towards creation. Because we imagine God as "using" us for his purposes, we "use" creation for ours. McFague's "Body Theology" is a deeply helpful corrective to this, imagining the universe as the very body of God. God's body can be hurt. In this body, everything has integral connection and relationship. All parts are useless without their connectivity to the other. To push McFague a little further, I will suggest that it is not only in imagining the universe as a body that we find a new context of place. But it is as Spirit baptized people in a Spirit baptized creation we find a new sense of unity and connectivity. To not be baptized in the Spirit as a follower of Christ is to entirely neglect and run against the Spirit in all creation that energizes and heals. Furthermore, as I will suggest in a future chapter, the Spirit of Pentecost seeks to return the voice to all the voiceless in creation. Body theology, such as McFague's, is a way of reimagining the earth as one deeply integrated in relationship.

Beyond a literary critique, Pentecostalism can rightly be informed by McFague's holistic soteriology. In a recent article she writes of our return to "the roots of the JudeoChristian tradition, a tradition that has insisted on the creator and redeemer God as the source and salvation of all that is. ${ }^{, 694}$ McFague addresses what she calls an ecological literacy, or the personal knowledge and set of language humans retain to speak of creation. Our ability to live with and live sustainably amongst creation is dependent on our ability to experience creation, especially in our language - for our language tells most

\footnotetext{
${ }^{694}$ McFague, "A Square in the Quilt," 46.
} 
our lived experience of creation. Soteriological healing, in this context, comes from lived experience of creation. Experience of creation, the laying on of hands to the world God created is a means of soteriological healing.

Sadly, I offer an unsatisfactory report on McFague's theology of the Spirit in her overall ecotheology. It would not be surprising that a majority of Pentecostals would disagree that McFague's definition of spirituality which, borrowed from the 1977 Scottish Church, ultimately fails to reflect the personal and dynamic image of the Spirit in the biblical narrative. By McFague's own standards, the definition of spirituality is "an exploration into what is involved in becoming human." ${ }^{695}$ This is striking, for McFague's borrowing of this definition is quite unlike her. McFague, against her larger methodological construction, defines spirituality as an entirely anthropocentric (not nonhuman) endeavor or quality. Does this imply that nonhuman creation lacks spirituality? Biblically, this does not fare well as the Spirit is repeatedly presented as a personal extension of God, in both human and nonhuman affairs.

Beyond this criticism, in the end, McFague offers that the Spirit plays the very important role of "hope-giver" in the midst of this nuclear age. By the Spirit, we hope for a healed creation. By the same Spirit, we hope for a reconciled universe. This Spirit brings hope to humanity to bring shalom to the planet in the current ecological crisis. McFague, to her credit, recognizing a lacking in her theology regarding the Spirit, has in recent writings sought to compensate for that lacking. While the Spirit plays little to no role as a person in her understanding of the Trinity and is largely relegated to one chapter

${ }^{695}$ McFague, Super, Natural Christians, 10. 
and one article, she suggests the Spirit brings a new sense of hope in a hopeless situation. McFague's social comprehension of the Spirit in giving hope to the hopeless in the midst of global crisis is compelling and must be an important part of any, including Pentecostal, ecopneumatology.

\subsubsection{Reflecting on Mark Wallace’s "Wounded Spirit”}

Finally, we now turn our attention to assessing the ecopneumatology of Mark Wallace. Wallace first offered us a novel and creative approach to understanding creation as "the Other" through the hermeneutical traditions of Girard, Ricoeur, and Levinas. Although Wallace's argumentation can at times be complex and overly nuanced, it would seem for our purposes here that his approach has opened a new way to imagine the complexity of the universe for Pentecostals. Wallace's forays into "scapegoat" theory and "mimetic desire" show how humanity has, in a way, chosen to stand in an oppositional posture towards nonhuman creation. Humanity is no longer viewed as being "with" creation but "above" creation. In a unique way, creation has become "the Other."

Part of the solution for Wallace is what he calls the "blurring" of lines between humanity and nonhuman creation. This calls for a human return to place within the context of the larger creation schemata. Wallace's construction in dialogue with late modernity is commendable. And it may have an interesting Pentecostal turn. Pentecostals are not immune to being "the Other." The earliest Pentecostals undoubtedly knew this Spirit baptism experience led to being a exclusivist people on the outskirts of both Christian and popular culture. It has only been in the last fifty years that Pentecostals have become, in a sense, mainstream. Pentecostals know what being "the Other" is like. Now, in light of the ecological crisis, I would suggest this affords Pentecostals a unique 
opportunity for solidarity with an ecological web very different from itself. Historically, the earliest American Pentecostals at Azusa Street developed a worship experience that intentionally blurred the lines between black and white. The Spirit made everyone one, despite skin color. It was the Spirit alone and immersion into that Spirit that made an environment where human solidarity was possible between members. In the setting of worship, as Pentecostals worship through the Spirit, they worship alongside creation filled with the same Spirit.

To therefore seek the health and unity of the creational order is part of the Spiritfilled life. As Wallace discusses the "Wounded Spirit," we are faced with a God who exists in solidarity with his broken creation on all levels. In this context, the Spirit beckons broken creation to again live in community not only through the life of the Trinity but the life of the church. We have already discussed the subject-object critique of McFague, but here we have a personalized version of it where the Spirit personally chooses to be wounded alongside a wounded creation. Through this, the vulnerability of God brings the Spirit near. What may perhaps be the destruction of a transcendent stance by humanity above creation as we have discussed? Vulnerability - the opening up to relationship. While there are dangers to such an approach, Wallace rightly shows us there is another side to the Spirit apart from the creative. God's Spirit is also present in destruction, pain, and at times violence. An examination of the scope of the nonhuman kingdoms will show that violence is a necessary part of creation, seeing death and disease in light of the life of the Spirit because it participates in both life and death in the scriptures. For Pentecostals who have little to no context for comprehending death, sickness, and pain aside from the demonic I would suggest Wallace's insights create 
possible inroads for a pneumatological view of death, sickness, and pain. However, I would offer misgivings about Wallace's biocentric approach in that it is at times difficult to discern the difference between God's creation and God's Spirit. But it does seem as though that is the point of Wallace's ecopneumatology: to create a theology that challenges their difference. Wallace understands the challenges of panentheistic thought and the difficulty many Christians may have with the topic. But his work opened me up to the opposite point. A large part of theology in the Christian tradition has too clearly emphasized the difference and separation of God from creation to a very unhealthy level.

We have now traversed the theological traditions of three of the more important ecotheologians in the twenty-first century. Furthermore, we have looked both at some critiques and possible points of Pentecostal construction. This has built on the previous two chapters, which have served as survey chapters regarding ecotheology and Pentecostal ecotheology. Now we are ready to move forward with one more chapter that will engage the field of Pentecostal pneumatology. After this, our final chapter will offer a constructive Pentecostal ecopneumatology for a twenty-first century ecological ethic. 


\section{Chapter 5}

\section{GEOGRAPHY OF THE SPIRIT-CENTRAL THEMES IN PENTECOSTAL PNEUMATOLOGY}

"In my junior year in high school, our homeroom teacher was a Jesuit priest named

Emmett Bienvenu. He buried our noses in the Acts of the Apostles, called it the gospel of the Holy Spirit, spoke of the Spirit as the forgotten God." ${ }^{696}$ - Donald Gelpi

\subsection{Introduction}

As we continue on our journey towards a Pentecostal ecopneumatology, this chapter will identify and examine four central themes in Pentecostal pneumatology: Spirit baptism, the Spirit of charismatic community, the holistic Spirit, and the Spirit of eschatological mission. Each of these pneumatological themes are drawn from a particular Pentecostal reading of the biblical text. ${ }^{697}$ Ultimately, each will serve as the framework within which we will construct a Pentecostal ecopneumatology in the final constructive chapter. Our previous chapter (chapter 4) examined three ecopneumatological dialogue partners that

\footnotetext{
${ }^{696}$ Gelpi, The Divine Mother, 2.

${ }^{697}$ For examinations of the Holy Spirit in the biblical tradition, see the following: French Arrington, Encountering the Holy Spirit: Paths of Christian Growth and Service (Cleveland: Pathway Press, 2003); C.K. Barrett, The Holy Spirit and the Gospel Tradition (London: SCM, 1947); Hendrikus Berkhof, The Doctrine of the Holy Spirit (Richmond: John Knox Press, 1964); Burgess, The Holy Spirit; Congar, I Believe in the Holy Spirit; James Dunn, The Christ and the Spirit: Collected Essays of James D.G. Dunn: Pneumatology, vol. 2 (Grand Rapids: Eerdmans, 1998); Gordon Fee, God's Empowering Presence: The Holy Spirit in the Letters of Paul (Peabody: Hendrickson, 1994); Sinclair Fergeson, The Holy Spirit (Downer's Grove: IVP, 1996); Ju Her, A Dynamic Reading of the Holy Spirit in Luke-Acts (London: Sheffield Academic Press, 2002); Kirsteen Kim, The Holy Spirit in the World: A Global Conversation (Maryknoll: Orbis, 2007); George Montague, The Holy Spirit: Growth of a Biblical Tradition (Peabody: Hendrickson, 1976); C.F.D. Moule, The Holy Spirit (Oxford: Mowbray, 1978); Eduard Schweizer, The Holy Spirit (London: SCM, 1980); Michael Welker, God the Spirit (Minneapolis: Fortress, 1994).
} 
exemplified particular ways of doing ecopneumatology in the twenty-first century.

Before this, we set out to the task of discovering the nature of both the wider Christian (chapter 2) and PC (chapter 3) ecotheological settings. Subsequently, following those preceding chapters, our examination of the four Pentecostal themes discussed here will afford us a way to move forward in developing a Pentecostal ecotheology and ecopneumatology for Pentecostal and ecumenical theologies.

We begin with a probing question from Allan Anderson: "When is a Pentecostal not a Pentecostal?" ${ }^{698}$ While efforts to define the characteristics of Pentecostal spirituality are extremely helpful, Anderson rightly considers a challenge when we attempt to distinguish what is not a Pentecostal? The problem Hollenweger had earlier articulated was that Pentecostalism had diversified and contextualized, nuanced in its every expression far beyond oversimplification and desire for theological categorization. ${ }^{699}$ This creates overwhelming challenges in defining Pentecostalism, especially ecclesiologically and theologically. Thanks to Hollenweger, the days of speaking of a Pentecostalism are dead. We shall forevermore have to speak of Pentecostalism(s). For what the "bombshell" of his The Pentecostals was the inevitability of a humbling suffix-s—for

\footnotetext{
${ }^{698}$ Allan Anderson, "When Is a Pentecostal Not a Pentecostal? When She's a Charismatic! Responding to Irvin, Lopez Rodriguez and Waldrop," JPT 16.1 (2007), 58-63 (59).

${ }^{699}$ Hollenweger, Pentecostalism. Hollenweger's preliminary work, published first in English in 1972, was important at the time for a number of reasons, perhaps no more than the complete ignorance on the part of the academy to the diverse sets of movements. Although works had previously been published on Pentecostalism, Hollenweger's work officially gave Pentecostalism a starting place in the academy not only for Pentecostalism but about Pentecostalism. For an earlier work, see Nils Bloch-Hoell, The Pentecostal Movement: Its Origin, Development, and Distinctive Character (London: Allen and Unwin, 1964).

Hollenweger is by far not the only one to distinguish the multifarious roots of Pentecostalism. For instance, Vinson Synan has done similar work. Vinson Synan, ed. Aspects of Pentecostal-Charismatic Origins (Plainfield: Logos International, 1975).
} 
Pentecostalism. ${ }^{700}$ In his shadow, Anderson clearly elucidates the difficulty with such a task bearing in mind the immanent diversity of the Pentecostal movements. ${ }^{701}$ Broadly, this diversification has led many in the Pentecostal fold to apologetically defend their distinctive positions so as to assume they need apology to more clearly define their identity. But this is based on a modern apologetic for apologetics intent on "winning the argument," a position both antiquated and unnecessary. Late modern apologetics no longer rely on "being right" as much as "being faithful" and "honest" to one's perspective. In our context, the greatest Pentecostal apologetic will be the willingness to be true to one's tradition. ${ }^{702}$ In that setting, we must decipher when a Pentecostal pneumatology is no longer a Pentecostal pneumatology, keeping in mind a Pentecostal difficulty in even coming to consensus. ${ }^{703}$ That is, what makes any pneumatology Pentecostal, per se?

This project forges ahead at a crucial time in global history for Pentecostalism as they continue to imagine and embody incarnational Spirit-filled living in their diverse global and local communal contexts. Following the exponential influx of Pentecostalism has arisen a complication in our understanding of what Pentecostal pneumatology truly comprises. With nearly 14,000 Pentecostal denominations, Pentecostal explanations of its pneumatological expressions equal in number. At this time, the gravity of their theological influence and legacy is playing an increased dramatic function in the shaping

\footnotetext{
${ }^{700}$ Macchia called Hollenweger's thesis regarding the diversity of Pentecostalism a "bombshell." Macchia, "The Kingdom and the Power," 111.

${ }^{701}$ Allan Anderson, "The Hazards of Writing a Book on Global Pentecostalism," PNEUMA 28.2 (2006), 283-288.

${ }^{702}$ Simon Chan makes a similar point in Chan, Pentecostal Theology and the Christian Spiritual Tradition, 7.

${ }^{703}$ Chan discusses the difficulty of Pentecostal self-identity and lack of consensus regarding their distinctive theology. Ibid., 7-16.
} 
of a global ("world") theology. ${ }^{704}$ Unlike a childhood of cultural isolation, Pentecostalism has in many ways matured widely, being accepted as a genuinely valid member of the ecumenical Christian body. ${ }^{705}$ Not only so, but Pentecostal movements have gained a reputable audience. Religious historian Philip Jenkins has shown the growing impact of Christianity in the Southern hemisphere. In his study, Jenkins takes special note of Pentecostalism, suggesting that the PC traditions are the "most successful social movements of the past century." ${ }^{, 706}$ By proxy, through the Charismatic, neo-Charismatic, and third-wave movements, Pentecostal spirituality—what Mark Cartledge has already called "the Charismatic Tradition"- - has shaped the broader church with an experiential impulse throughout mainline expressions, global Protestantism, RC, and to some degree the Orthodox communion. ${ }^{707}$ Yet this impulse has been a two-way street. For reciprocally, these movements have shaped historic Pentecostalism in their own distinct ways. Even beyond Jenkins suggestion, it may be suggested that PC spirituality is one of the most successful, if not influential, theological movements of the past century. With this said, it surely seems possible that the Pentecostal influence theologically stems from

\footnotetext{
${ }^{704}$ While some prefer "world theology" in an effort to protect theological diversity, "Global theology" is intentionally utilized here. On this, see Yong, The Spirit Poured out on All Flesh, 18.

${ }^{705}$ This is illustrated by a Pentecostal acceptance into the National Association of Evangelical (NAE) in 1945 showing a larger acceptance by the global community. Although this acceptance is widely true, many continue to offer stiff challenges to particular elements or doctrines of the Pentecostalism. Having said this, by and large, there has been an ecumenical openness to Pentecostalism in the twenty-first century. This cannot be said of the Oneness traditions, who encounter significant resistance (theologically) within the global Christian community. On Pentecostal connection to ecumenism, see Cecil Robeck, "Pentecostals and the Apostolic Faith: Implications for Ecumenism," PNEUMA 9.1 (1987), 61-84.

706 Jenkins, The Next Christendom, 8. See also Milton Acosta, "Power Pentecostalisms: The 'NonCatholic's Latin American Church Is Going Full Steam Ahead--but Are We on the Right Track?," CT 53.8 (2009), 40-42.

${ }^{707}$ On this "Charismatic Tradition" see the whole of Cartledge, Encountering the Spirit.
} 
a distinctly Pentecostal "pneumatological imagination" or "foundational

pneumatology., ${ }^{, 708}$

It was for good reason that missiologist Leslie Newbigin suggested in 1954 that Pentecostalism was a "third force" behind Protestantism and the RC traditions. ${ }^{709}$ Harvey Cox, commenting on the so-called "primal spirituality" of a rapidly expanding Pentecostalism, argued that this Pentecostal force "opens people to new outpourings of the divine Spirit." 710 But what is it that gives strength to this third force? Is there anything significantly "new" about this primal spirituality found in Pentecostalism?

What Newbigin, Cox, and others have taken note of regarding Pentecostalism is perhaps an important element of their experiential pneumatology. For Pentecostal pneumatology claims to emphasize an experiential impulse modeled by those typified in the narrative of a Pentecost community illustrated in Acts 2. This perhaps explains, to some degree, Pentecostalism's numerical success mentioned by those observers previously pointed out. Pentecostal pneumatology may similarly account for the profound influence Pentecostalism has had on Protestantism, RC, and the Orthodox. This is particularly the case in early-twentieth century Protestantism where a pneumatological hunger swelled in the discipline of theology. This hunger can be illustrated best by the

\footnotetext{
${ }^{708}$ As mentioned, this parallels what Kärkkäinen has called the "pneumatological renaissance.” Kärkkäinen and Yong, eds., Toward a Pneumatological Theology. Both phrases are borrowed from Amos Yong, whose terminology of the "pneumatological imagination" and "foundational pneumatology" are helpful here and throughout. On "pneumatological imagination," see Yong, Spirit-Word-Community. For the "foundational pneumatology" eschewing Cartesian categories paralleling Donald Gelpi's Trinitarian pneumatology utilized by Yong, see Amos Yong, "On Divine Presence and Divine Agency: Toward a Foundational Pneumatology," AJPS 3.2 (2000), 167-188. Gelpi earlier defines "foundational pneumatology" as the "integrally converted Christian to experience the facet of the Christian God we call the Holy Spirit." Gelpi, The Divine Mother, 7-10.

${ }^{709}$ Leslie Newbigin, The Household of God (New York: Friendship Press, 1953), 30.

${ }^{710}$ Cox, Fire from Heaven, 310.
} 
pneumatological writings of Karl Barth in dialogue and disputed with the German idealism of his day. ${ }^{711}$ Barth's yearnings for a pneumatological turn in theology is further seen in his desire "of a new theology which would begin with the third article of the creed." ${ }^{112}$ This hunger continues in Protestantism. For today, Michael Welker, Jürgen Moltmann, and Wolfhart Pannenberg illustrate this swell aptly on a contemporary scene. ${ }^{713}$ For these and others, Pentecostalism has offered an element of the theology of the Spirit they have been searching for. As we have seen, this same pneumatological thrust has similar currents in the RC tradition through Yves Congar, Teilhard de Chardin, Kilian McDonnell, and Catherine LaCugna, to mention a few. Through a late-twentieth century RC pneumatological awakening, Pentecostalism has emerged as a powerful dialogue partner in the shaping of said theology.

Pentecostalism has brought to the ecumenical table a pneumatology of experience. William and Robert Menzies agree, suggesting, "Pentecostals have traditionally been long on action and short on reflection., ${ }^{, 714}$ Pentecostal scholar Gordon Fee has agreed in regards to hermeneutics, writing, "It is probably fair-and importantto note that in general the Pentecostals' experience has preceded their hermeneutics." ${ }^{715}$

\footnotetext{
${ }^{711}$ Karl Barth, The Holy Spirit in the Christian Life: The Theological Basis of Ethics. Trans. R. Birch Hoyle (London: F. Mueller, 1938).

${ }^{712}$ Quoted in Moltmann, The Spirit of Life, 1. (Italics Mine) For an exhaustive list of Barth's works on a doctrine of the Spirit, see Eugene Rogers, After the Spirit: A Constructive Pneumatology from Resources Outside the Modern West (Grand Rapids: Eerdmans, 2005), 19-23.

${ }^{713}$ Welker's theology is paramount to understanding Protestant pneumatological imagination. For introductions to his work, see Michael Welker, God the Spirit; Michael Welker, The Work of the Spirit: Pneumatology and Pentecostalism (Grand Rapids: Eerdmans, 2006). Pannenberg as well is a seminal pneumatological voice within Protestantism. See his Wolfhart Pannenberg, Systematic Theology, 3 vols. (New York: T\&T Clark, 2004).

${ }^{714}$ William Menzies and Robert Menzies, Spirit and Power: Foundations of Pentecostal Experience (Grand Rapids: Zondervan, 2000), 209, (italics mine).

${ }^{715}$ Gordon Fee, "Hermeneutics and Historical Precedent — a Major Problem in Pentecostal Hermeneutics," in Perspectives on the New Pentecostalism, ed. Russell Spittler (Grand Rapids: Baker, 1976), 118-132
} 
All three would most likely agree: Pentecostal theology has been more strongly situated in action over and above theological reflection. This is an important tension for Pentecostalism and one that must be given ample attention. In this tension, academic and written theology is put in a different category than theological experience. In this way, it can be said that Pentecostal written theology of the Spirit continues to play catch up with its experiential theology of the Spirit. ${ }^{716}$ Many reasons might account for this. For instance, it would seem this "catching up" has arisen from Pentecostalism's widespread entrance into the global ecumenical community such as the NAE and the WCC. Its growth undeniably has played into this "catching up."

Today, as a successful social movement with tremendous numerical advances, Pentecostalism is attempting to make available for the world its theology which it has come to experience privately in the last century. Now, in the context of a global theology, Pentecostal theology has come under heightened examination. While Pentecostal experience has enjoyed significant growth and influence, it has brought with it a new set of questions regarding the nature of its theology of experience. Thus, with the most recent Pentecostal academic coming out, the question of the content of their pneumatology

(122), (italics mine). Thanks to Stephen Parker for this point in his Stephen Parker, Led by the Spirit, 9. Parker, here, points out that even Fee (friend) and Dunn (foe) agree on this very important point: that "the tendency of Pentecostals [is] to be more oriented toward 'experience' than 'theology."'

${ }^{716}$ This reflects many often quoted aphorisms describing a Pentecostal biblically-infused hermeneutic: "In the beginning there was an experience and a testimony, then came an explanation in the form of a theological construct." Quoted in Jean-Daniel Pluss, "Azusa and Other Myths: The Long and Winding Road from Experience to Stated Belief and Back Again," PNEUMA 15.2 (1993), 189-201 (201). This notion is seen no more prominently than in the robust discussion and considerable conversation that followed the work of Mark Noll, The Scandal of the Evangelical Mind (Grand Rapids: Eerdmans, 1995). For responses by Pentecostals to Noll's thesis, see Cheryl Bridges Johns, "Partners in Scandal: Wesleyan and Pentecostal Scholarship," PNEUMA 21 (1999), 183-197; James K. A. Smith, "Scandalizing Theology: A Pentecostal Response to Noll's Scandal," PNEUMA 19 (1997), 225-238; Amos Yong, "Whither Systematic Theology?: A Systematician Chimes in on a Scandalous Conversation," PNEUMA 21 (1999), 85-93. The literature on the central motif of experience in Pentecostalism is extensive. Begin with the following Henry Lederle and Matthew Clark, What Is Distinctive About Pentecostal Theology? (Pretoria: University of South Africa, 1989), 35-65. 
continues to be raised. ${ }^{717}$ This is matched by another important cultural impact. For, especially in a Western setting, the broader topic of "spirituality" has become increasingly significant. ${ }^{718}$ Because of this combination of influences, Gelpi has suggested that Pentecostal experience has come at a high time when everyone seems to be talking about "spirituality." Pentecostal experiential pneumatology is far more developed than its theological writing of the Spirit. ${ }^{720}$ This creates a challenge for academic Pentecostal pneumatology and especially in regards to defining its very nature.

With this experiential pneumatology has come a broader openness to converse with the pneumatological traditions outside of Pentecostalism. This has undeniably led to a more underscored ecumenism and interreligious openness. This, alongside increased academic attention, has forced upon Pentecostalism the need to more appropriately express their theology in academic settings. What has followed is a surge of Pentecostal publications and academic societies that have more readily attempted to be theologically

\footnotetext{
717 This is the working out of what Yong calls "Academic Glossolalia." Amos Yong, "Academic Glossalalia: Pentecostal Scholarship, Multi-Disciplinarity, and the Science-Religion Conversation," JPT 14.1 (2005) 61-80.

${ }^{718}$ For a sweeping study of "spirituality" cross-denominationally and interreligiously, see Cheslyn Jones, Geoffrey Wainwright, and Edward Yarnold, eds., The Study of Spirituality (New York: Oxford, 1986). More specifically, for a topical primer on Christian "spirituality" with special attention given to mystical theology, see Edith Humphrey, Ecstacy and Intimacy: When the Holy Spirit Meets the Human Spirit (Grand Rapids: Eerdmans, 2006). For a more pointed study on Pentecostal "spirituality," see the classic Land, Pentecostal Spirituality. Land here defines spirituality as "the integration of beliefs and practices in the affections which are themselves evoked and expressed by those beliefs and practices." Ibid., 13. On the separation of formal theology and "spirituality" in the West with special note to its renewal as evidenced in mystical theology, see McIntosh, Mystical Theology.

${ }^{719}$ Thanks to Donald Gelpi for this point. Delpi writes in the context of the primitive Christian communities, "Christians experienced the Spirit before they formulated pneumatologies." That is, the proto-orthodox ecclesial pneumatological teaching was not written theology but an experienced theology. Gelpi, The Divine Mother, 7.

${ }^{720}$ Undoubtedly, the danger of any overly experiential religious tradition can lead to what Simon Chan has called "the religious version of the fashion world." He believes this is exemplified by the Charismatic movements of Pensacola and Toronto. See Chan, Pentecostal Theology and the Christian Spiritual Tradition, 8-9.
} 
conversant with those inside and outside their own tradition. This theological wrestling which has invited an emphasized ecumenical openness has truly brought new issues to bear for Pentecostals. The conversation, for Pentecostals, has become more than simply discussing glossolalia and initial evidence in the twenty-first century. Kilian McDonnell, in writing about the theology of the Spirit in the primitive church, writes that it was perpetually "stumbling in the right direction."721 The same could be said of contemporary Pentecostal pneumatology. Pentecostal pneumatology has more than ever in its history begun to dialogue theology with other traditions in contexts not their own. For, by and large, glossolalia remains a less important aspect for Reformed, Anabaptist, and mainline traditions who often view many Pentecostal expressions as a coalition of "charismatic Gnostics" who hold a secret experience that they themselves lack. ${ }^{722}$ But Pentecostal pneumatology has expanded beyond the glossolalia conversation. ${ }^{723}$ To its credit, a broader Pentecostal pneumatology has emerged grappling with other important topics such as social justice, domestic violence, disability theology, theology of religions, interfaith dialogue, and, as we are seeing, ecology.

As we continue with this chapter, we will attempt to answer the question: what actually comprises a Pentecostal pneumatology? Many answers have been suggested. For instance, Latino Pentecostal scholar Nestor Medina offers what he believes to be the four central elements of this Pentecostal pneumatology. Medina writes, "First, the lived moments in which people find the reality of the divine in their regular everyday activities

\footnotetext{
721 Kilian McDonnell, “A Trinitarian Theology of the Holy Spirit,” TS 46.2 (1985), 191-227.

722 I borrow "charismatic Gnostics" from Simon Chan in his Chan, Pentecostal Theology and the Christian Spiritual Tradition, 9.

${ }^{723}$ This is true on many levels. Margaret Poloma's helpful analysis of the Assemblies of God has shown that the practice of glossolalia has waned significantly at the end of the twentieth century, or at least shifted in focus. Poloma, Assemblies of God at the Crossroads, 40. But it is also the case on a broader level.
} 
despite poverty, pain and death; second, the trust of the people that in their religious practices (reading the Bible, singing, praying, fasting) the divine is made present and revealed anew; third, the expectation that in encountering the diving, reality and human beings are transformed by the power of the Holy Spirit; fourth, the realization of one's being in relation with the divine and within a community of believers." 724 Utilizing this four-part comprehension of the pneumatological experience for Pentecostals, Medina sums up this experience: "When Pentecostals come together they expect something to happen." 725 It is in this expectancy, what Emil Brunner alluded to as the "pneumatic factor," that Pentecostals find their hope and spiritual vitality. ${ }^{726}$ As has Medina, we must attempt to isolate the themes of Pentecostal pneumatology in hopes to frame novel form of creational experience that will manifest itself for Pentecostals. In our own attempt, I would here like to identify and discuss four themes of Pentecostal pneumatology: Spirit baptism, the Spirit of charismatic community, the holistic Spirit, and the Spirit of eschatological mission.

\footnotetext{
${ }^{724}$ Nestor Medina, "Jürgen Moltmann and Pentecostalism(S): Towards a Cultural Theology of the Spirit," in Love and Freedom, ed. Abrahim Khan (Toronto: Toronto School of Theology, 2008), 101-113 (103).

${ }^{725}$ Ibid., (italics mine). Medina's article proposes a so-called pneumatological cultural kenosis whereby, using Moltmann's foundation, the Spirit can be understood as functioning in and throughout the life of culture to draw people to God. This is similar to Simon Chan's description of the Charismatic lifestyle, writing, "Life of grace as having a charismatic dimension that is open to surprises from God." Chan, Spiritual Theology, 10.

${ }^{726}$ Quoted in Larry Christenson, "Pentecostalism's Forgotten Forerunner," in Aspects of PentecostalCharismatic Origins, ed. Vinson Synan (Plainfield: Logos International, 1975), 15-37 (27). For original citing, see Emil Bruner, The Misunderstanding of the Church (Philadelphia: Westminster, 1953), 51-52.
} 


\subsection{Spirit Baptism}

For PCs, Spirit baptism is an integral element of the salvation experience centered primarily on the Luke-Acts narrative of the Spirit of God in the Trinity, the church, the believer, and the world. Classic Pentecostal spirituality is historically traced either to Charles Parham's Bible School in Topeka, Kansas (1900-1902), ${ }^{727}$ or the Los Angeles Azusa Street revival (1906-1909). Through both of these trajectories, Spirit baptism is closely tied to what is described as a "subsequent" experience. This experience is commonly described as the dramatic, overwhelming experience of the Holy Spirit connected to conversion with the subsequent experience of "speaking in tongues" (glossolalia) as a "sign" of this experience. ${ }^{728}$ Yet despite their similar historical and theological beginnings, the divergence between Parham's and Seymour's vision of Spirit baptism and its larger purposes were in many ways nuanced if not entirely divergent. ${ }^{729}$ Despite these differences, in broad strokes, contemporary Spirit baptism among

\footnotetext{
${ }^{727}$ Sarah Parham, The Life of Charles F. Parham: Founder of the Apostolic Faith Movement (Joplin: Hunter Publishing, 1930).

${ }^{728}$ I agree with Frank Macchia who contends the linguistic usage of "evidence" is neither biblical nor helpful in the conversation. In its place, Macchia contends that "sign" is a more adequate descriptive. Frank Macchia, "Tongues as a Sign: Toward a Sacramental Understanding of Pentecostal Experience," PNEUMA 15.1 (1993), 61-76; Frank Macchia, "Groans Too Deep for Words: Towards a Theology of Tongues as Initial Evidence," AJPS 1.2 (1998), 149-173. The literature on the "subsequentialist" theology of early Pentecostals is rather extensive. To begin, see Carl Brumback, What Meaneth This? (Springfield: Gospel Publishing House, 1947); Carl Brumback, Suddenly...From Heaven (Springfield: Gospel Publishing House, 1961); Donald Gee, Pentecost (Springfield: Gospel Publishing House, 1932); Ralph Riggs, The Spirit Himself (Springfield: Gospel Publishing House, 1949). A full outline of bibliographic sources can be found at Gary McGee, ed. Initial Evidence: Historical and Biblical on the Pentecostal Doctrine of Spirit Baptism (Peabody: Hendrickson, 1991), 119-130.

${ }^{729}$ Parham's use of xenolalia, or known tongues/languages as used for evangelistic purposes, is believed to be interconnected to his eschatological anticipation of Christ's return and the evangelism necessary for such a return. Agnes Ozman, a member of Parham's Bible school, is believed to have spoken in Chinese on the eve of the Pentecostal outpouring. Seymour, on the other hand, contended for glossolalia, and believed it to be utilized more as a sort of "racial reconciliation" for all worshippers to come together in one Spirit. On these important difference, see Allan Anderson, "The Dubious Legacy of Charles Parham: Racism and Cultural Insensitivities among Pentecostals," PNEUMA 27.1 (2005), 51-64.
} 
Pentecostals can to a great extent be described as the relived experience found in the Acts of the Apostles. But what entails Spirit baptism?

Spirit baptism has a compelling element of what Mark Cartledge calls an "encounter with the Spirit," the experience of a personal and enlivening Holy Spirit encounter paradigmatic of that illustrated in the book of Acts and reconstituted in various recent movements such as, but not relegated to, Azusa Street. ${ }^{730}$ This encounter, writes Peter Hocken, is the full revelation of the Triune God through God's abiding Spirit. ${ }^{731}$ Yet even, in the setting of Pentecostal diversification, the doctrinal understanding of Spirit baptism has proliferated. Simon Chan, referencing the current context, has argued that there still lacks what he calls "traditioning" in Pentecostal communities regarding such doctrines. ${ }^{732}$ The difficulty in defining Spirit baptism almost certainly arises from sociological and theological diversification in the twenty-first century of Pentecostal communities. For truly, as Kärkkäinen has rightly suggested regarding Spirit baptism, "the final word has not been said.",733

\footnotetext{
${ }^{730}$ The overall thesis of Cartledge, Encountering the Spirit.

${ }^{731}$ Peter Hocken, "The Meaning and Purpose of 'Baptism in the Spirit'," PNEUMA 7.2 (1985), 125-134.

${ }^{732}$ Simon Chan has argued that a major problem with a Pentecostal practice of Spirit baptism is what he calls a lack of "traditioning." Chan, Pentecostal Theology and the Christian Spiritual Tradition, 10-16. That is, the Spirit baptism experience proves a challenging one to pass off to the younger generation if based solely on doctrine. Ultimately, Chan articulates that experience of Spirit baptism is easily passed on ("traditioned") while the formal doctrine is not. His point is taken here, but with qualification. Chan himself points out that Pentecostals lack a self-understanding of their own perspective on Spirit baptism and thus lack a unified doctrinal stance with which to "tradition." I would suggest the only "traditioning" that effectively passes on to the next generation within this doctrine is a contextual experience differing throughout the variant movements. For as I have pointed out, the earliest American Pentecostals, Parham and Seymour, "traditioned" the next generation in their own way. This diversity is part of the genetic makeup of Pentecostalism.

${ }^{733}$ Kärkkäinen and Yong, eds., Toward a Pneumatological Theology, 193.
} 
Frank Macchia, in his sweeping examination of the topic, characterizes Spirit baptism as the crown jewel of Pentecostal theology. ${ }^{734}$ In his study, Macchia suggests that the importance of this is evidenced in the broader context of Pentecostal writing and theology in the last forty years. He writes, "If you were to purchase a book by a Pentecostal theologian prior to the 1970 s on the most cherished doctrine of the Pentecostals, it would most assuredly be about Spirit baptism."735 This illustrates the importance of Spirit baptism not only in practice and theology, but also in the short history of Pentecostal academia. Simon Chan similarly reflects, "[W]hat comes through over and over again in their [Pentecostals'] discussions and writings...is a certain kind of spiritual experience of an intense, direct, and overwhelming nature centering on the person of Christ which they schematize as 'baptism in the Holy Spirit.",736 It can be established, despite times checkered with unclarity and ambiguity, that this Spirit baptism motif emerges over and over again in Pentecostal literature despite being a theological

\footnotetext{
734 Throughout his very important Frank Macchia, Baptized in the Spirit: A Global Pentecostal Theology (Grand Rapids: Zondervan, 2006).

${ }^{735}$ Frank Macchia, "Baptized in the Spirit: Towards a Global Pentecostal Theology," in Defining Issues in Pentecostalism, ed. Steven Studebaker (Eugene: Pickwick, 2008), 13-28 (13).

736 Thanks again to Macchia for this quote, originally found in Chan, Pentecostal Theology and the Christian Spiritual Tradition, 7. To echo this point of the importance of Spirit baptism, Keith Warrington has proposed "that which most distinguishes Pentecostalism is the doctrine relating to the baptism in the Spirit." Warrington, Pentecostal Theology, 19. For another article on Macchia's point in relation to "Spirit baptism," see Macchia, "Baptized in the Spirit." For a historical analysis of Spirit baptism, see Henry Elderly, Treasures New and Old: Interpretations of 'Spirit-Baptism' in the Charismatic Renewal Movement (Peabody: Hendrickson, 1988). On an ecumenical vision of Spirit baptism, see Koo Dong Yun, Baptism in the Holy Spirit: An Ecumenical Theology of Spirit Baptism (Lanham: University Press of America, 2003). And finally, for a larger discussion on the difference between linguistic categories (e.g. "with," "in," "by") regarding the Holy Spirit, see Arrington, Encountering the Holy Spirit, 96-103.
} 
strain notoriously difficult to assess and define academically. ${ }^{737}$ And steadily, shifts have emerged in how Pentecostals imagine and practice the doctrine.

This historically rich doctrine of Spirit baptism has experienced a strong undercurrent of reform in the twenty-first century, part of a larger global shift in pneumatological focus. F. LeRon Shults has investigated elements of these pneumatological shifts in late modern scholarship examining the pneumatologies of Michael Welker, Elizabeth Johnson, Amos Yong, and Mark Wallace. ${ }^{738}$ Shults observes a shift away from dualism (negative views of matter and positive views of Spirit) in line with the European Enlightenment, a dualism that has seen fruition in Protestant theology in particular. Shults, in turn, has called pneumatology (Pentecostal or not) a "reforming pneumatology." ${ }^{\text {739 }}$ Today, we must highlight what may be called a reforming Spirit baptism within Pentecostalism. For Pentecostal pneumatology has, in this way, opened up significantly in its understanding of this Spirit baptism. But what are these reforms? And what are the catalysts for this reform in Pentecostal Spirit baptism? I would suggest here a number of reasons for these shifts with particular attention to three: Dunn's and Bruner's critiques of Pentecostal pneumatology, an enlarged pneumatology, and the birth of the Charismatic, neo-Charismatic, and third-wave movements.

First, Pentecostal pneumatology, alongside the doctrine of Spirit baptism, has been under reform since an intense set of challenging works in the 1970s by means of two leading Protestant theologians: Dale Bruner and James Dunn. Their representative

\footnotetext{
${ }^{737}$ Larry Christenson aptly wrote, "There is a sound theology for the baptism with the Holy Spirit. But the baptism with the Holy Spirit is not a theology to be discussed and analyzed. It is an experience one enters into." Larry Christenson, Speaking in Tongues (Minneapolis: Dimension Books, 1968), 40.

${ }^{738}$ Shults, "Spirit and Spirituality."

${ }^{739}$ Ibid., 284.
} 
texts, Baptism in the Holy Spirit (Dunn) and A Theology of the Holy Spirit (Bruner), have since sparked decades of robust pneumatological dialogue for Protestants and Pentecostals alike. ${ }^{740}$ Through their analysis of the Pentecostal doctrine of Spirit baptism, Bruner and Dunn offered a theological critique whereby Pentecostal pneumatology was put under a microscope for the broader theological world to see. Ultimately Bruner's and Dunn's works, sympathetic and yet polemical, called into question various elements of Pentecostal pneumatological claims regarding the Spirit and, ultimately, their theology of Spirit baptism. Exegetically, Dunn argued that the Pentecostal Spirit baptism doctrine inadequately represented the narrative of the historical text of the book of Acts and the larger Pauline corpus. Bruner, likewise, leveled similar critiques, calling Pentecostal theology overtly "Pneumatobaptistocentric." ${ }^{\text {"741 }}$ These critiques were viewed, in some respect, as a sign of good things to come by Pentecostals. For them, even Bruner's and Dunn's willingness to simply address Pentecostal theology as prolific Protestant theologians was a sign of Pentecostalisms' growing importance. Dunn himself even found intrinsic value in the Pentecostalism, writing, "Against the mechanical sacramentalism of extreme Catholicism and the dead Biblicist orthodoxy of extreme Protestantism, they [Pentecostals] have shifted the focus of attention to the experience of

\footnotetext{
${ }^{740}$ The two main texts are Dale Bruner, $A$ Theology of the Holy Spirit: The Pentecostal Experience and the New Testament Witness (Grand Rapids: Eerdmans, 1970); James Dunn, Baptism in the Holy Spirit: A ReExamination of the New Testament Teaching on the Gift of the Spirit (Philadelphia: Fortress, 1970). Critiques of the two-stage "subsequentialist" perspective have been similarly leveled by J.I. Packer, Keep in Step with the Spirit (Leicester: IVP, 1984); John Stott, Baptism and Fullness: The Work of the Holy Spirit Today (Downer's Grove: IVP, 1964); Max Turner, Power from on High: The Spirit in Israel's Restoration and Witness in Luke-Acts, JPTSup, vol. 9 (Sheffield: Sheffield Academic Press, 1996). Stott's work perhaps had the most influential assault on a popular level going through nine printings. Within, Stott argues that Pentecostals have a "Jesus-plus" theology offering a Spirit baptism of works. For a most helpful synopsis and engagement of this, see chapter 1 of Martin Mittelstadt, The Spirit and Suffering in Luke-Acts: Implications for a Pentecostal Pneumatology, JPTSup, vol. 26 (London: Continuum, 2004).

${ }^{741}$ That is, "Spirit baptism-centered."
} 
the Holy Spirit. ${ }^{, 742}$ Although most certainly, by and large, Bruner and Dunn have both been major assessments that Pentecostal pneumatology has had to hurdle.

What Bruner's and Dunn's critiques perhaps awakened most was a greater awareness of the differences between the theology of Spirit baptism in the Pauline and Lukan corpi. This brought an important issue to the forefront: Pentecostals have traditionally given preeminence to a Lukan pneumatology stressing the missiologicalempowering motif of Spirit baptism at the expense of Pauline pneumatology emphasizing the soteriological motif. Many responses, such as Harold Hunter's Spirit Baptism, attempted to grapple with this challenging thesis. ${ }^{743}$ Similarly, some Pentecostal scholars, such as Gordon Fee, have produced perhaps the greatest and most substantive text on Pauline pneumatology to date as a response to this claim. ${ }^{744} \mathrm{Fee}$, aware of the contention that Pentecostals have seemingly neglected Paul, with, of course, exception to 1 Corinthians 12-14, sought to elucidate a Pauline corpus of theology for Pentecostal pneumatology ${ }^{745}$ Fee, exemplifying a keen eye for the Spirit in Paul's thirteen letters, systematically exegetes Pauline pneumatology, making available to Pentecostal scholarship a key reference for a theology of the Spirit that goes beyond the Lukan works. But what Fee reminds us is that every reader of the biblical text, Pentecostal and non-Pentecostal alike, plays their hermeneutical preferences in their own unique way. In this sweeping text, non-Pentecostals are critiqued by Fee as "embarrassing" in their

\footnotetext{
${ }^{742}$ Dunn, Baptism in the Holy Spirit, 225.

${ }^{743}$ Harold Hunter, Spirit-Baptism: A Pentecostal Alternative (Lanham: University Press of America, 1983).

${ }^{744}$ Fee, God's Empowering Presence.

${ }^{745}$ Ibid., 10.
} 
almost entirely neglecting the Pauline charismata theology of 1 Corinthians $12-14 .^{746}$ Another, the Charismatic Donald Gelpi, argues that Dunn's thesis limits Paul's understanding of charismata in that it fails to integrate Paul's theology of celibacy as gift, thus limiting the broader role of the Spirit in the soteriological economy. ${ }^{747}$ Many more responses have likewise been solicited. After the dust had settled some two decades after his own writing, Dunn still contends that Pauline and Lukan pneumatology are one and the same, writing, "the pneumatology of Luke is essentially one with the pneumatology of Paul., ${ }^{, 78}$ Pentecostal scholarship largely continues to see something special and unique to the Lukan pneumatology.

The second major impetus for this reforming Spirit baptism theology arises in response to Bruner's and Dunn's critique and can best be described as a critique of what I would call here a myopic pneumatology. As Pentecostals responded to Dunnexemplified by father and son William and Robert Menzies in their Spirit and Power (2000) — an appropriated yet apologetic response offered a defense of classic Pentecostal Spirit baptism based on a particular reading of Acts. ${ }^{749}$ While broadly attempting to engage and reconstruct the larger Pentecostal pneumatology, a significant portion was devoted entirely to the critiques of Dunn. This is so much so, that in Menzies' text, an entire chapter was titled "Exegesis: A Reply to James Dunn." "750 Undoubtedly this work by the Menzies, and others such works, continued to play an increasingly important role

\footnotetext{
746 Ibid.

${ }^{747}$ For a very helpful discussion on a critical response to Dunn from the charismatic Gelpi, see Gelpi, The Divine Mother, 77.

748 James Dunn, "Baptism in the Holy Spirit: A Response to Pentecostal Scholarship on Luke-Acts", JPT 3 (1993), 3-27.

${ }^{749}$ Menzies and Menzies, Spirit and Power.

${ }^{750}$ Ibid.
} 
in defending a classic Pentecostal pneumatological identity of Spirit baptism. ${ }^{751}$ Other more apologetic responses of its type exist, such as that by OT scholar Howard Ervin who attempted a chapter-by-chapter counterassault on Dunn's work. ${ }^{752}$ While Bruner's analysis tended to be much more theologically motivated relying mostly on exegesis, it is Dunn's entire exegetical method with which Ervin will take issue. Ervin's critique, similar to a swath of literature from his time, demonstrates skepticism of Dunn's apparent presuppositional choices eventually affecting his overall theological venture; the very thing Dunn suggested Pentecostals had done in theirs by allowing their hermeneutics to be shaped by their experience.

But a greater response was beckoning Pentecostal theology. In the wake of these Spirit baptism debates, other Pentecostal scholars began to observe something inadequate in the Pentecostal responses to the critiques of Dunn and Bruner that centered on one or two aspects of Spirit baptism. One such example, Martin Mittelstadt, contends this set the stage for a battle that fought over the wrong turf. He suggests that the dialogue should have been moved forward from arguing over pneumatological issues such as Spirit baptism and initial evidence. ${ }^{753}$ Mittelstadt rightly points out that, "For much of the first seventy-five years of Pentecostalism, defense of Spirit baptism remained an internal endeavor." 754 Now, having become an external battle, the rules of engagement had

\footnotetext{
${ }^{751}$ Interestingly, their Spirit baptism theology is rather cosmological in scope. They write, "The Salvation provided by Jesus as Lord and Savior is cosmic in nature and includes physical wholeness." Ibid., 165.

${ }^{752}$ Howard Ervin, Conversion-Initiation and the Baptism in the Holy Spirit (Peabody: Hendrickson, 1985). Of similar interest is Ervin's later "subsequentialist" work on the topic based on a robust NT exegesis-a revised edition of an earlier work from 1968 readily quoted by Dunn in his own text. See Howard Ervin, Spirit Baptism: A Biblical Investigation (Peabody: Hendrickson, 1987). For a most helpful overview of Ervin's hermeneutical method, see Kärkkäinen and Yong, eds., Toward a Pneumatological Theology, 9-15. ${ }^{753}$ Mittelstadt, The Spirit and Suffering in Luke-Acts.

${ }^{754}$ Ibid., 20.
} 
shifted. Thus, the Spirit baptism conversation shifted from one regarding Pentecostal identity to one of a Pentecostal defense. On a whole, Mittelstadt's own scholarship has taken on a tenor of challenge to Pentecostals in this regard. His Spirit and the Suffering in Luke-Acts attempts to "extend beyond" the Spirit baptism argument that has so often set the pneumatological stage for Pentecostals in the 1970s and 1980s. ${ }^{755}$ For this conversation that so heavily relies on the distinction between the soteriological ordo salutis of Christian initiation and "subsequent" theologies of infilling of the Spirit that has in essence become, for Mittelstadt, a long overplayed dialogue. Mittelstadt's critique illustrates a growing sense of frustration towards a Pentecostal pneumatology overtly concerned with subsequence, thus illustrating a desire to envision both Spirit baptism and Pentecostal pneumatology in an enlarged way. For Pentecostal Spirit baptism theology has more to do with these two issues raised by Bruner and Dunn.

Thirdly, following the critiques of Dunn and Bruner and a call for an enlarged Spirit baptism pneumatology, the impact of the Charismatic, neo-Charismatic, and thirdwave movements have done much to shift the focus of Spirit baptism in Pentecostal practice and theology. While the historic Pentecostal movements in the United States have almost entirely held a view of Spirit baptism as it related to a "subsequent" experience, Pentecostals have had to engage traditions all other than their own with testimonies of individuals experiencing Spirit baptism and charismata in very different ways than their own Pentecostal experience. This has brought up an important conversation on Spirit baptism regarding ordo salutis for the "sacramentalist" and "subsequentialist" approaches. On a whole, two central ways of models have emerged on

${ }^{755}$ Ibid., 3-7. 
how to conceptualize Spirit baptism within PC theology: the sacramentalist and the subsequentialist models. ${ }^{756}$ The sacramentalist model envisions Spirit baptism—along with evidences of the Spirit's infilling — central to initiation rites of water baptism or communal affirmation, oftentimes in the act of confirmation. ${ }^{757}$ This perspective, representative primarily of many Charismatics, is best articulated by Montague and McDonnell's historical/theological work. ${ }^{758}$ As RC Charismatics, McDonnell and Montague maintain that Spirit baptism utilized by Pentecostals is a valid doctrine and has a tradition in the universal church as it is connected to ecclesial sacraments such as baptism or confirmation. ${ }^{759}$ For them, its historical connection to sacrament is illustrated in the first eight centuries of Christian history. Peter Hocken's thoughtful analysis, both of the sacramentalist and subsequentialist views, suggests the former is not as historically clear-cut as Montague and McDonnell would suggest. ${ }^{760}$ Hocken suggests this view is "a Catholic view," not "the Catholic view." ${ }^{, 761}$ He argued that Pentecostals were more theologically grounded to the earliest comprehensions of the Spirit baptism than were the

\footnotetext{
${ }^{756}$ Simon Chan makes a good point however that on a broader level within the Christian tradition there is the sacramentalist and nonsacramentalist perspectives. While agreeable, we focus on a Charismatic and Pentecostal typologies. On the separation of these two as helpful typologies of the diverse understanding of Spirit baptism, see Chan, Pentecostal Theology and the Christian Spiritual Tradition, 53-56.

${ }^{757}$ This is interestingly the case with many RC Charismatics, many Anglican Charismatics, and Oneness Pentecostals. For instance, the baptismal formula for Oneness Pentecostals is divergent from orthodox and historical baptismal formulas referring to the Father, Son, and Holy Spirit.

${ }^{758}$ Kilian McDonnell and George Montague, Christian Initiation and Baptism in the Holy Spirit: Evidence from the First Eight Centuries (Collegeville: Liturgical Press, 1994). This fascinating study has stimulated many important discussions among Pentecostals regarding the historical nature of Pentecost-like experiences in non-Pentecostal churches. Montague focuses his section on the NT texts themselves while McDonnell the postbiblical/church historical texts. Both McDonnell and Montague have laid foundational pieces for cross-traditional understandings of the Spirit baptism especially in regards to ecumenism.

${ }^{759}$ For another helpful analysis of a Charismatic theology of glossolalia and "initial evidence," see Henry Lederle, "Initial Evidence and the Charismatic Movement: An Ecumenical Appraisal," in Initial Evidence: Historical and Biblical Perspectives on the Pentecostal Doctrine of Spirit Baptism, ed. Gary McGee (Peabody: Hendrickson, 1991), 131-141.

${ }^{760}$ Peter Hocken, "Baptized in Spirit—an Eschatological Concept: A Response to Norbert Baumert and His Interlocutors," JPT 13.2 (2005), 257-268.

${ }^{761}$ Thanks to Peter Hocken for this quote in his ibid., 162.
} 
RCs. Agreeing with him, Norman Baumert argued that a NT theology of Spirit baptism (baptizein en pneumati) was an entirely different category from Christian initiation on a biblical level in agreement with F.A. Sullivan's earlier thesis. ${ }^{762}$

A second Spirit baptism model is the "subsequentalist" view. Within the subsequentialist view of Spirit baptism—most strongly advanced by classic Pentecostalism — Spirit baptism is envisioned as a secondary (or third) experience closely connected to sanctification, being based on a number of stories in the narrative of Acts. ${ }^{763}$ In Pentecostal practice, this will often come by the laying on of hands and may or may not be paired with glossolalia (or xenolalia) and is ultimately connected to eschatologically missional implications. ${ }^{764}$ Other Pentecostals suggest variant "signs," such as, in one case, prophecy. ${ }^{765}$ It is this view of Spirit baptism that often separates Pentecostalism in practice and theology from other Christian traditions - although some have argued Spirit baptism is not necessarily the reason for this separation. For instance, Kenneth Archer posits that a Pentecostal exclusivist separation from other Christian groups was not because of their view on Spirit baptism or entire sanctification, but rather

\footnotetext{
762 Norbert Baumert, “'Charism' and 'Spirit-Baptism': Presentation of an Analysis,” JPT 12.2 (2004), 147179; Francis Sullivan, Baptism in the Holy Spirit: A Catholic Interpretation of the Pentecostal Experience (Rome: Gregorian University Press, 1974), 49-68.

763 Although, clearly, this "normative" reading that advocates glossolalia in the book of Acts has found critics even among some Pentecostals such as Gordon Fee. Fee addresses this issue, illuminating the difficulties of developing a doctrinal system on biblical precedent alone - such as Spirit baptism accompanied by glossolalia in some instances of the Luke-Acts account. See his Gordon Fee, "Baptism in the Holy Spirit: The Issue of Seperability and Subsequence," PNEUMA 7.2 (1985), 87-100. See also the very succinct and helpful Larry Hurtado, "Normal, but Not the Norm: 'Initial Evidence' and the New Testament," in Initial Evidence: Historical and Biblical on the Pentecostal Doctrine of Spirit Baptism, ed. Gary McGee (Peabody: Hendrickson, 1991), 189-201.

764 Again, as is the case for Robert Menzies who maintains that Spirit baptism is not connected to soteriological functioning but more to a missiological emphasis. Robert Menzies, Empowered for Witness: The Spirit in Luke-Acts, JPTSup, vol. 6 (Sheffield: Sheffield Academic, 1994).

${ }^{765}$ For instance, Simon Chan suggests, "Might not prophesy serve as a better than glossolalia?" Chan, Pentecostal Theology and the Christian Spiritual Tradition, 43.
} 
their claim of special narrative, what he calls "a particular twist on the Christian story. ${ }^{, 766}$ Frank Macchia, perhaps one of the more influential Pentecostal scholars on Spirit baptism, writes of the subsequentialist experience: "Whatever else it is, Spirit baptism is a powerful experience received with or at a moment distinct from Christian initiation.. ${ }^{967}$ Macchia's work is nonetheless a unique shift in Pentecostal scholarship, for he demonstrates a novel openness within Pentecostalism to a more inclusive understanding of Spirit baptism. In his subsequentialist model, Macchia embraces a hybrid view whereby Spirit baptism can often occur outside our normal Pentecostal comprehension of ordo salutis.

Within this context, what are emerging as contemporary trajectories of the Spirit baptism doctrine in Pentecostalism? Recent decades have exhibited rapid adaptation and novel imagination having been spurred on by the shifts already mentioned. With these changes, fresh and novel approaches to Spirit baptism have been constructed. For instance, Stephen Land's ecumenically sensitive Pentecostal Spirituality expands Hollenweger's controversial thesis that the first ten years of the Pentecostal movement "form the heart, not the infancy of the spirituality." ${ }^{768}$ Although Land's text devotes little attention to Spirit baptism, he illuminates the need to go beyond Spirit baptism and glossolalia, writing that "more is needed than an apologetic for Spirit baptism or yet another study of behaviors such as glossolalia." ${ }^{, 769}$ To amplify Land, twenty-first century

\footnotetext{
766 Archer, "Pentecostal Story," 38.

767 Macchia, Baptized in the Spirit, 153.

768 Land, Pentecostal Spirituality, 13. This argument is made by Hollenweger in Walter Hollenweger, "Pentecostals and the Charismatic Movement," in The Study of Spirituality, eds. Cheslyn Jones, Geoffrey Wainwright, and Edward Yarnold (New York: Oxford, 1986), 549-554.

${ }^{769}$ Land, Pentecostal Spirituality, 20-21.
} 
Pentecostal spirituality is beginning to go beyond such apologetics. Furthermore, Land writes that it must "emphasize the lived reality of the faith, the life and service of the people of God who are organically constituted as the body of Christ by the indwelling of the Holy Spirit." 770 That is, Land contends, the point of Paul in 1 Corinthians 12 regarding the charismatic community is to live in fullness by the power of the Spirit. Land's approach offers a revisioning of Pentecostal spirituality as the marriage of thought and lived theology. It is in this marriage that one is birthed "a passion for the kingdom."

Similarly, renewed creative hermeneutical approaches have arisen from these Spirit baptism dialogues. For instance, one of the greatest benefits of the zenith of Spirit baptism theology is an intense and focused renewal in Lukan scholarship by Pentecostals. We observe this in Roger Stronstad's approach to Luke's narrative and theology. ${ }^{772}$ In his seminal text, Stronstad seeks to unravel a PC understanding of Luke's pneumatology in front of the backdrop of Dunn's critique. In short, Stronstad suggests that Luke's biblical contribution is more than simply a historians' account of Jesus and the church. But, Stronstad contends, Luke's work offers but a full-fledged theological endeavor in his own right and may in fact differ in some respects from Pauline pneumatology. Luke's theology, says Stronstad, should therefore not be forced to fit into the same mold as

\footnotetext{
770 Ibid., 33.

771 That is the subtitle and theme of the book.

772 Roger Stronstad, The Charismatic Theology of St. Luke (Peabody: Hendrickson, 1984). See also his Roger Stronstad, Spirit, Scripture and Theology: A Pentecostal Perspective (Baguio City: Asia Pacific Theological Seminary Press, 1995). This is by far only the beginning of this intensified Lukan study within Pentecostal studies. See also Robert Menzies, The Development of Early Christian Pneumatology with Special Reference to Luke-Acts, JSNTSup, vol. 54 (Sheffield: Sheffield Academic Press, 1991); Menzies, Empowered for Witness; John Penny, The Missionary Emphasis of Lukan Pneumatology (Sheffield: Sheffield Academic Press, 1997); James Shelton, Mighty in Word and Deed: The Role of the Holy Spirit in Luke-Acts (Peabody: Hendrickson, 1991).
} 
Paul's. ${ }^{73}$ What Stronstad creates is an exegetical space for the power of the Spirit to be made manifest through Luke-Acts as it is found in Luke-Acts. Others, such as Gary McGee, have worked to continue to keep the topic of Lukan "initial evidence" at the forefront by means of uncovering historical backing for Spirit baptism practice as the hallmark of both Parham's and Seymour's ministry in the earliest stages of the movement. ${ }^{774}$ Max Turner willingly offers an alternative to Pentecostal pneumatology preoccupied with discussion regarding "initial evidence" in his Power From on High. ${ }^{775}$ This work, the fruit of nearly twenty solid years of Lukan pneumatological scholarship within the Pentecostal tradition, projects a conceptual model of the Spirit based on the ongoing process in the believer's sanctification. In one broad sweep, Turner revitalizes the soteriological role of the Spirit through careful exegesis of Luke-Acts. But mostly, Turner argues for a holistic pneumatology so often neglected in Pentecostal scholarship. Turner writes that the emphasis must go beyond initial evidence of the Spirit to the "ongoing evidence" in the continued sanctification and prophetic filling of the Spirit. ${ }^{776}$ This importance comes at a time when "two-step" pneumatology has for some time envisioned salvation/subsequent indwelling as the pattern of the Spirit in Acts. Even

\footnotetext{
${ }^{773}$ Stronstad was not the first to argue this. Originally in 1953, Hans Conzelmann suggested that Luke was a theologian in his own right in his The Theology of St. Luke. For the original German edition, Hans Conzelmann, Die Mitte Der Zeit: Studien Zur Theologie Des Lukas (Tubingen: J.C.B. Mohr, 1960). Another example is the eschatologically-centered Eric Franklin, Christ the Lord: A Study of the Purpose and Theology of Luke-Acts (Philadelphia: Westminster, 1975). See also W. Ward Gasque, A History of the Interpretation of the Acts of the Apostles (Peabody: Hendrickson, 1989); I. Howard Marshall, Luke: Historian and Theologian (Grand Rapids: Zondervan, 1989). Thanks to Yong for these helpful resources in his Yong, The Spirit Poured out on All Flesh, 84.

${ }^{774} \mathrm{McGee}$, ed., Initial Evidence. This edited volume is a treasure trove of material for understanding and developing not only Pentecostal pneumatology, but also the doctrine of initial evidence. As well, perhaps one of the more helpful historical/theological explications of Seymour's theology is Douglas Nelson, "For Such a Time as This: The Story of Bishop William J. Seymour and the Azusa Street Revival" (PhD Dissertation, University of Birmingham, UK, 1981).

${ }^{775}$ Turner, Power From on High.

${ }^{776}$ Ibid., 453.
} 
sacramentalist Pentecostal traditions carry this same mantle, often asserting the Spirit falls at confirmation. Turner contends both are unsatisfactory on the basis that it does not always reflect the Lukan tradition.

Also, while traditional comprehensions of Pentecostal Spirit baptism have rested on the bifurcation of Christian initiation (salvation) from a subsequent Spirit sanctification and infilling, others suggest it could better rest on an eschatological foci as a central element of Christ's eventual return. For example, in responding to Norbert Baumert's critique of Montague and McDonnell's text, ${ }^{777}$ Peter Hocken contends it is the eschatological nature of Spirit baptism that the earliest Pentecostals had in mind, not the initial evidence. ${ }^{778}$ That is, the central importance of Spirit baptism is in preparation of the coming eschaton for the work of the ministry to prepare the coming harvest. While a "two-step" pneumatology exemplified in Pentecostal scholarship has remained a staple focus of Pentecostal pneumatology, Hocken and others offer an alternative view of Spirit baptism. $^{779}$

Hocken illustrates the contextual nature of Spirit baptism which has had different meanings at different times in Pentecostal history. Shane Clifton has similarly shown this in observing a number of problems with this two-step type of pneumatology we are

\footnotetext{
${ }^{777}$ McDonnell and Montague, Christian Initiation and Baptism in the Holy Spirit. For Baumart's critique, see Baumert, "'Charism' and 'Spirit-Baptism'."

${ }_{778}$ Hocken, "Baptized in Spirit-an Eschatological Concept."

${ }^{779}$ Yong, The Spirit Poured out on All Flesh, 99. Yong's point suggests there is a false understanding of a sort of stepping-stone soteriology in Pentecostal, Holiness, and Wesleyan spirituality that tends to neglect the "process" nature of Spirit baptism which should rightly be subsumed in the ongoing process of salvation. The result otherwise can lead to what has often been dubbed "Charismatic triumphalism."
} 
speaking of ${ }^{780}$ Clifton's reminder is that Pentecostal pneumatological understandings of Spirit baptism, especially in what he calls a "voluntarist" culture largely eschewing clerical triumphalism as illustrated in the revivalism of John Wesley, must be understood contextually both within history and geography. ${ }^{781}$ Clifton writes, "[E]cclesially constitutive experiences of the Spirit of Christ, reflected upon firstly in the scriptures and also other texts of various sorts, [must be] judged and developed in specific historical settings (special and geographical)." ${ }^{.782}$ Ultimately, for Clifton, Spirit baptism may provide varied meanings for contextual Pentecostal experiences. This contextual Spirit baptism has practical implications, such as Macchia's suggestion of a Spirit baptism motif that rightly involves Christian action in light of the coming sanctification of creation as part of eschatological preparation. ${ }^{783}$ Here Spirit baptism plays an eschatological role in bringing in both a new heaven and a new earth with cosmic implications.

This brings us to some very important questions. Why should Bruner's claim that Pentecostals are pneumabaptistocentric rub them the wrong way? Could we not say the Reformed tend towards dogmacentricism? And are not Baptist communities evangelistocentric? And are the Methodist communities socioevangelistocentric? Perhaps

\footnotetext{
${ }^{780}$ Shane Clifton, "The Spirit and Doctrinal Development: A Functional Analysis of the Traditional Pentecostal Doctrine of the Baptism in the Holy Spirit," PNEUMA 29.1 (2007), 5-23 (16). Clifton contends that much of the Pentecostal understanding of the Spirit "is that the Pentecostal doctrine is sometimes seen to deny the Spirit to non-Pentecostals."

${ }^{781}$ For a synopsis of Wesley's understanding of the Spirit and his view of entire sanctification, see William Arnett, "The Role of the Holy Spirit in Entire Sanctification in the Writings of John Wesley," WTJ 14 (1979), 15-30; Russell Staples, "Reasonable Enthusiast: John Wesley and the Rise of Methodism," AUSS 29.2 (1991), 135-185.

${ }^{782}$ Clifton, "The Spirit and Doctrinal Development," 11.

${ }^{783}$ Frank Macchia, "The Kingdom and the Power: Spirit Baptism in Pentecostal and Ecumenical Perspective," in Work of the Spirit, ed. Michael Welker (Grand Rapids: Eerdmans, 2006), 109-125.
} 
in taking Macchia and Hollenweger a step further, it may be fair to argue that all Spirit baptism doctrines and experiences (including the Pentecostal) are inherently contextual. ${ }^{784}$ Again, Parham and Seymour held differing views on the purpose of Spirit baptism. Parham's view of glossolalia offered an eschatological fervor to evangelism in the revival that emerged in Kansas in the early twentieth century. Seymour saw Spirit baptism at the Azusa Street revival as the rebirth of a new humanity, free from the bondages of racism and hatred. For, truly, Spirit baptism has always been understood in different ways at different times in Pentecostalism. Amos Yong, highlighting this diversity, has said that Spirit baptism, "taken as a NT metaphor for the full salvific work of god, in fact demands a variety of experiences." ${ }^{, 785}$ This leads us to a greater sensitivity of the language of Spirit baptism as a metaphor for Spirit-inebriated and Spirit-immersed living, whatever that means in each setting.

As an arresting reminder of Trinitarian theology, Spirit baptism forces on all theological paradigms the acceptance of a broader comprehension of the community of the Trinity. This “spirituality of the Spirit," alluded to in Chan's work, acutely corrects any benign theological work that highlights the Father and Son to the ignorance of the Spirit. ${ }^{786}$ It rightly emphasizes the entire economy of salvation from God's creation of the world, to atonement at the cross, to empowerment and sending of the Spirit. Just as we "work out" (Phil. 2:12) our salvation, we "keep in step with the Spirit" (Gal. 5:25). Thus, every element of this salvific economy is to be lived and practiced. Spirit baptism forces upon the infilled a trust not only in Christ's cross and the empty tomb as much as the

\footnotetext{
${ }^{784}$ Ibid., 111.

${ }^{785}$ Yong, The Spirit Poured out on All Flesh, 119.

${ }^{786}$ Chan, Spiritual Theology.
} 
continual infilling of God's Spirit. At its climax, then, Spirit baptism critiques Western models of the monarchial Trinity that overemphasize the Father, a model highlighted by the West and perpetuated by RC and a vast portion of Protestantism. Asian Yee Tham Wan has contended that Pentecostal spirituality offers a "linear model" of the Spirit proceeding from the Son who is begotten from the Father ${ }^{787}$ Hollenweger, and others, have asserted that Pentecostal spirituality should spend more effort connecting the Spirit with Eastern and Greek models of the Trinity perhaps for the very reason Wan wrote what he did. ${ }^{788}$ Spirit baptism, therefore, is a turn towards the openness to mystical experience the East has been more attuned. ${ }^{789}$

Pentecostals, therefore, center on pneumatology in the same way the Reformed traditions emphasize the Word and RCs the Father. But does this pose a problem? Spirit baptism, as the opening of the human experience to the possibility of an omnipresent God in his incarnation, is involved in the minutia of life and opens up new doors of contact with others, such as interreligious dialogue. Amos Yong demonstrates in Spirit-WordCommunity that there exists a "trialectic" whereby the Word and Spirit—as extensions of the Father-find space to live in Trinitarian community without losing their essential identity. ${ }^{790}$ This opening has increasingly created a contribution by Pentecostals to the ongoing conversation of the theology of religions made popularly accessible by Raimon Panikkar and Jacque DuPuis. Kärkkäinen has similarly contributed to a better

\footnotetext{
${ }^{787}$ Yee Tham Wan, “'The Spirit of Your Father': Suggestions for a Fuller Pentecostal Pneumatology with Accompanying Pastoral Implications," AJPS 10.2 (2007), 219-228 (224).

${ }^{788}$ For Hollenweger's argument, see Hollenweger, "All Creatures Great and Small."

${ }^{789}$ This sort of Pentecostal "mysticism" is alluded to in Terry Cross, "The Divine-Human Encounter Towards a Pentecostal Theology of Experience," PNEUMA 31.1 (2009), 3-34.

${ }^{790}$ Yong, Amos, Spirit-Word-Community.
} 
understanding of Pentecostal pneumatology with relationship to a theology of religions. Kärkkäinen contends that pneumatological comprehension of interreligious relation can only be found grounded in Trinitarian theology where the Father, Son, and Spirit live in free love and relation to each other. ${ }^{791}$ His argument, mirroring Amos Yong's work in Beyond the Impasse, contends pneumatology is largely the scene where this can take place. ${ }^{792}$ Kärkkäinen ultimately concludes that pneumatology is a "proper context" for advancing theology of religion dialogue ${ }^{793}$ Moreover, he agrees with Yong's assessment that the three elements of pneumatology as they intersect with theology of religion are correct: God's universal presence in the world, God's presence in the imago Dei, and God's sustaining presence among the religions for his own purposes. ${ }^{794}$

Finally, illustrated by the omnipresent Spirit in the religions by Yong and Kärkkäinen, there remains a salient creational turn in this reforming Spirit baptism we have been speaking of. Frank Macchia writes: "[T]he final word will not be said of Spirit baptism until the resurrection of the dead and the new heavens and new earth make the entire creation God's dwelling place. To make creation God's dwelling place is to transform it, for new wine cannot inhabit old wineskins." ${ }^{, 795}$ What Macchia argues is that Spirit baptism is the present state of being until God lives in and embodies all of creation. But it is also the presence of a God in the world preparing the new creation. This Spirit baptism is God's solidarity with the groaning creation living incarnate in the very one

\footnotetext{
${ }^{791}$ Veli-Matti Kärkkäinen, “'How to Speak of the Spirit among Religions’: Trinitarian Prolegomena for a Pneumatological Theology of Religions," in Work of the Spirit, ed. Michael Welker (Grand Rapids:

Eerdmans, 2006), 47-70.

${ }^{792}$ Amos Yong, Beyond the Impasse: Toward a Pneumatological Theology of Religions (Grand Rapids: Baker Academic, 2002).

${ }^{793}$ Kärkkäinen, “'How to Speak of the Spirit among Religions'," 48.

${ }^{794}$ Ibid., 54.

${ }^{795}$ Macchia, Baptized in the Spirit, 19.
} 
who groans (Rom. 8:28). Macchia continues, "When couched within the prophetic tradition, the eschatological continuity between the 'already' and the 'not yet' Kingdom implies that the apocalyptic act at the end of this age will not be one of total annihilation of the world but one of total transformation of the world." ${ }^{.796}$ Macchia points to three ways the Spirit and Spirit baptism are preparing this transformation of the world. First, the Spirit draws all to the love and mercy found in the gospel of Christ through regeneration, whereupon the Spirit baptism is commenced upon the believer. Second, Spirit baptism must be understood more as a "process" event through the daily life of the believer, such as through water baptism. Third, the Spirit-filled believer is empowered for Kingdom service. Each of these help prepare a new creation that is coming.

\subsection{The Spirit of Charismatic Community}

We now turn to identify our second theme of Pentecostal pneumatology—-the Spirit of charismatic community. Pentecostal ecclesiology in its enlivened form is perhaps best illustrated by this charismatic community, or the "fellowship in the Spirit." Peter Kuzmic and Miroslav Volf suggest that one of the various strategies to apprehending ecclesiological imagination within Pentecostalism is to observe their emphasis on the Trinitarian theology of fellowship, where the Triune God leads communal existence "by the Spirit through one another." ${ }^{797}$ Ultimately, this Trinitarian fellowship leads to the charismatic life of fellowship amongst the church. That is, true authentic ecclesial

\footnotetext{
${ }^{796}$ Dempster, "Christian Social Concern in Pentecostal Perspective," 62.

${ }^{797}$ Kuzmic and Volf described this in a position paper presented at the International RC-Pentecostal Dialogue, Riano, Italy, May 21 st-26 $6^{\text {th }} 1985$, (unpublished). Quoted in Kärkkäinen and Yong, eds., Toward a Pneumatological Theology, 109-122.
} 
fellowship flows directly from an authentic Trinitarian theology. The narrative of the book of Acts, therefore, becomes the narrative of the church living as the Trinity, in total and unending pneumatic fellowship in a dark world. ${ }^{798}$ Luke's portrayal of the charismatic church is one that shines light as a community existing paradigmatically as Christ's beacon of hope in the kingdom of this age. This church, then, becomes the community of invitation - inviting darkness to come in the light. This is effectively illustrated in Paul's first canonical letter to the Corinthians as he expresses a community where the nonbeliever can walk into a Spirit-filled church and proclaim, "God is really among you. ${ }^{, 799}$ Similarly, the picture of Acts 2:12 shows observers of Peter's sermon at Pentecost remarking, "What does this mean?" Astounded, other observers comment on the apparent "drunkenness" of the inhabitants of this charismatic community in the upper room. ${ }^{800}$ This is the charismatic community that draws all to fellowship through the Spirit's activity.

A noticeable direct relationship between the charismatic community is discernable; for as the church is drawn to Christ by the Spirit, the world draws near to the church for whom Christ sacrificially died. The upper room at Pentecost imaginatively

\footnotetext{
${ }^{798}$ I term this the "reconstituted" ecclesiological narrative of Acts in Pentecostal theology and practice. For instance, on the reconstitution of Acts as a model and narrative of the current church life and expression, see Stronstad, The Charismatic Theology of St. Luke; Roger Stronstad, The Prophethood of All Believers: A Study in Luke's Charismatic Theology, JPTSup, vol. 16 (Sheffield: Sheffield Academic Press, 1999). Kärkkäinen's pneumatic ecclesiology insists that in order to overcome what Bernard Cooke refers to as the "distancing of God" from the laity and what Jaroslav Pelikan calls the "aristocracy of the Spirit," we need to reconsider the role of the Word and Sacrament in relation to the charismata in ministry. See his Kärkkäinen and Yong, eds., Toward a Pneumatological Theology, 133. Others, such as Matthew Clark and Henry Lederle, emphasize the Kerygmatic nature of this PC community. See their Lederle and Clark, What Is Distinctive About Pentecostal Theology?, 67.

${ }^{799} 1$ Cor. 14:25.

${ }^{800}$ Which, interestingly enough, is not the only biblical connection between drunkenness/inebriation and Spirit baptism. Frank Macchia calls this a "fluid metaphor." On this "fluid metaphor" of the Spirit and Spirit baptism, see also Acts 2:12, 1 Cor. 12:12-15, Eph. 4:5, and 5:15-18. See also Macchia, Baptized in the Spirit, 14.
} 
offers an image of a meeting place for Christ with his church and the church with the world. All parties are present in the upper room. This leads to a challenge for Pentecostals in trying to determine how one defines the very nature of church. Is it an institutional church? Is the Spirit-filled church?

Utilizing Anderson's own outlining of the nature of the Pentecostal movements, I find a profitable assist for our purposes here. Anderson outlines a more diverse understanding of Pentecostalism when compared to such ecclesial models as Robert Mapes Anderson's examination, who rightly finds historical rooting in Los Angeles yet often ignores the deeper complexity of the remainder of Spirit-filled movements globally. Building on such complexity, Anderson suggests that Pentecostalism is a movement that emphasizes not only the experience of the Holy Spirit but its experience particularly in charismatic community. ${ }^{801}$ That is to say Pentecostalism is primarily to be understood in terms of Spirit experience over and against a more denominational/historical view as illustrated by Robert Mapes Anderson. Allan Anderson's analysis contends that the broader theological and historical setting for Pentecostal movements, before, within, and beyond Azusa Street, emphasizes an ecclesial model based on charismatic community. Therefore, it is important that we note that charismatic community is the communal partaking by divergent traditions in the upper room of the Spirit's presence transcending denominationalism.

It is in this proverbial upper room where individuals from all walks of life are called into equal fellowship with the resurrected Christ. There are social dimensions to

\footnotetext{
${ }^{801}$ Anderson, "When Is a Pentecostal Not a Pentecostal?" See also his Anderson, An Introduction to Pentecostalism.
} 
this upper room experience that may help explain the exponential growth of the Charismatic traditions, what James Smith calls "small-p" Pentecostals. ${ }^{802}$ In this context, participants from any movement can retain their long-held traditions, traditional theology, and yet experience the Pentecostal Spirit in charismatic community. The earliest Pentecostal communities were inherently nondenominational for this very reason. Because Spirit baptism and charismatic community transcended lines of race and gender, they would similarly transcend denominational lines, thus rendering them unessential. Andrea Hollingsworth, touching on this, has suggested four distinctive descriptive elements of this charismatic community: Spirit baptism by the laying on of hands, charismata as the outflow of spiritual gifts amongst the community of faith, shared narrative and experience, and finally, Spirit-filled worship —or "inspired space" evidenced by ecstatic outflow and speaking in tongues. ${ }^{804}$ Charismatic community is understood primarily in a communal experience. Ultimately, for Hollingsworth, it is this very nature of the experiential that is often neglected in academic pneumatology, an emphasis PC traditions are attempting to revitalize. Hollingsworth forcefully advances this thesis suggesting an often gapping disconnect between academic theology (pneumatology), and lived and shared praxis. ${ }^{805}$ The end result is a theology with little to

\footnotetext{
${ }^{802}$ James K. A. Smith, “Thinking in Tongues,” FT April (2008), 27-31 (29).

${ }^{803}$ I borrow this from Adolf Holl, The Left Hand of God: A Biography of the Holy Spirit, trans., John Cullen (New York: Doubleday, 1997), 10.

${ }^{804}$ Hollingsworth's study here focuses both on Sarah Coakley's pneumatology and feminist discourse as well as the relation between Pentecostal pneumatology and feminist movements. Hollingsworth, "Spirit and Voice." In regards to shared narrative and worship, Cheryl Sanders suggests this thread as the "sanctified church," evidenced in shared worship experience, within her own black Holiness-Pentecostal tradition. Cheryl Sanders, Saints in Exile: The Holiness-Pentecostal Experience in African American Religion and Culture (New York: Oxford University Press, 1996), 192.

${ }^{805}$ Hollingsworth, Spirit and Voice, 193.
} 
no lived (experiential) foundation. And the completely developed extension of this charismatic motif has yet to fully extend to the larger ecumenical academic table.

As shown in Luke's theological development from his gospel (on the life of Jesus) to Acts (on the life of Jesus in the church), the Spirit-filled church becomes the continued presence of Christ on earth. ${ }^{806}$ Luke's depiction of the ecclesial community as the extension of Christ's ministry following his death, resurrection, and ascension mesmerizes Pentecostal theology for a number of reasons. First, as mentioned, Luke-Acts plays a leading role in PC pneumatological theology offering a historical precedent for apostolic presence and practice in the late modern world. That is, Jesus's work continues in Luke-Acts beyond the cross and continues in the church today. As well, secondarily, Luke-Acts has shown itself foundational for the earliest Pentecostals as a central text for parousiac expectancy—a sort of sign of our current "intermezzo." ${ }^{807}$ In this framework, the church and creation are in a holding pattern awaiting fulfillment and completion. It is this intermediate time frame where all earth is prepared for the coming harvest. In commenting on Luke's stylistic historical/theological discourse, Robert Gallagher has rightly perceived that it fits well into shaping Pentecostal theology. He writes, "[T]his Gentile writer is not always concerned with the precise Trinitarian functions that would satisfy systematic theologians. ${ }^{808}$ Luke, therefore, becomes the experiential writer for practice. Lastly, and perhaps most notably, Luke-Acts remains a foundational text-

\footnotetext{
806 This is the main thesis of Stronstad, The Charismatic Theology of St. Luke.

${ }^{807}$ That is, a short instrumental movement in an opera or musical performance. Arnold a Van Ruler first used this as a metaphor for the Spirit's role in the world preparing the world for the parousia. Thanks to Robert Gallagher for this reference. Robert Gallagher, "The Holy Spirit in the World: In Non-Christians, Creation and Other Religions," AJPS 9.1 (2006), 17-33.

${ }^{808}$ Ibid., 18. This important piece appraises the theology, and particularly the pneumatology of two Protestant theologians: Arnold a Van Ruler and Paul Fries. It also asks the question of the Spirit's role in the world, creation, and the life of the nonbeliever.
} 
along with such NT books of 1 Corinthians and Ephesians - for a theology of charismata in community life as an extension of Christ's ministry. While cessationism has experienced some attention, Pentecostals have over and over utilized, repetitiously, LukeActs in some sort of a competition with Pauline pneumatology often used as a backdrop of cessationism. While Pauline literature, as mentioned in 1 Corinthians, offers a theology for charismata, Luke-Acts goes out of its way to expand a theology of the Spirit's ongoing gifting in the community of faith. Based on these reasons Pentecostal identity is closely connected to a self-comprehension of being the extension of Christ to the world.

It is with this self-identity as the continued presence of Christ on earth as a backdrop that this charismatic community fostered a sense of ecumenical fervor in its earliest Pentecostal formation; a fervor that has in many ways waned. Again, pneumatology is the central thrust of this for the Spirit blows in lands near and far. Historically speaking, Pentecostalism began as an ecumenically charged movement spanning denominational borders and bringing with it the experience of the aforementioned Spirit baptism. ${ }^{809}$ In this way, Spirit baptism and the experience of speaking in tongues serves as a sort of ecumenical middle ground between PC and nonPentecostals who have both experienced Spirit baptism. Yet, inevitably, the fires that spread from Los Angeles and Topeka did much both to divide and bring believers together. On one hand, Spirit baptism brought fire to seeming dying institutions in earliest Pentecostalism. But on the other hand, charismatic experience gave a bridge for

\footnotetext{
${ }^{809}$ For a discussion of the Montanist movement and its overall struggle to fit within patristic ecclesiastical systems and the possible connections between the Montanist and Pentecostal movements with comment to their similar struggle, see Hans Campenhausen, Ecclesiastical Authority and Spiritual Power in the Church of the First Three Centuries (Peabody: Hendrickson, 1997).
} 
cross-denominational experience to be discussed as these Spirit experiences entered various traditional circles. Spirit baptism became their ecumenical gathering. Yet because of this experiential impulse, often compared to the Montanist movements of the patristic period, Pentecostals were often maligned and unwelcomed in non-Pentecostal circles by nature of their claiming special experience. This is why Larry Christenson has contended the Pentecostal movements have always had a paradoxical ecumenical/exclusivist bent. ${ }^{810}$ They claimed an exclusivist experience that they believed fostered ecumenism. The two struggled to live together. Furthermore, Kärkkäinen has noted that Pentecostalism has brought a number of pneumatological elements to the ecumenical table, mostly in how the Spirit relates to the Trinity as well as a theological construction of interreligious dialogue based on the Spirit. ${ }^{811}$ Ecumenically, through the global body of Christ, Spirit baptism gives the community a new sense of Spirit fervor.

This experience has always drawn the lower sociological strata of human society. But this is welcome news for Pentecostals, for in Pentecostal pneumatology the Spirit empowers the socially lowly for pneumatic service. For if these lowly have been Spirit baptized, they are somebody of value in this new community. That is to say, the Spirit gives equal footing to all participants for service. Simon Chan has argued elsewhere that "the primary focus of Spirit baptism is to actualize our communal life." ${ }^{.12}$ It is this same Spirit that gives power for the lowly to serve Christ's purposes. This is illustrated by the historical PC theological emphasis on the role of women and blacks as an essential part of the egalitarian pneumatic community. Although this emphasis has not perpetuated

\footnotetext{
${ }^{810}$ Christenson, "Pentecostalism's Forgotten Forerunner," 31-32.

${ }^{811}$ See his Kärkkäinen, Pneumatology.

${ }^{812}$ Simon Chan, "Mother Church: Toward a Pentecostal Ecclesiology," PNEUMA 22.2 (2000), 177-208.
} 
entirely in the West where PC churches often carry on hierarchical male-domination despite this view. Others still yet emphasize the role of women in evangelism, pastoring, and apostolic positions. ${ }^{813}$ This view of pneumatic service remains a challenging critique to many Pentecostal power structures such as male and female relations within the church. Although for many, as Sarah Coakley has shown, the role of heightened pneumatology will do much to even out an egalitarian ecclesiology ${ }^{814}$ Coakley points out how interesting it is that there is a perpetual male hierarchical power structure in light of Pentecostalism's emphasis on the third person of the Trinity, the female rûach. The charismatic community is therefore a family of members serving God on equal grounds.

The Spirit in the charismatic community similarly fosters a new sense of identity. Pentecostal theologian Keith Warrington writes that a salient feature of Pentecostal pneumatology is closely linked to the idea of family as its social basis. ${ }^{815}$ Here he finds a parallel between pneumatology and the supernatural family and identity within that family. Warrington pinpoints the Spirit's role as "functioning as the one who sets believers apart to God, confirming that they are children of God." ${ }^{\text {"16 }}$ There remains therefore a dynamic sense of family under the outpoured Spirit of Pentecost. At the Azusa Street revival, the Spirit of Pentecost fell on the very people, seemingly unworthy of Christian service, as it did nearly two thousand years earlier in Acts 2 by falling on a gathering of fisherman, tax collectors, and zealots. This seems to clearly articulate why

\footnotetext{
${ }^{813}$ For instance, we must acknowledge the ministry of Aimee Semple McPherson as a key historical figure in the shaping of the Pentecostal female identity. See Edith Blumhofer, Aimee Semple Mcpherson: Everybody's Sister (Grand Rapids: Eerdmans, 1993).

${ }^{814}$ See Coakley's helpful article, Sarah Coakley, “Femininity' and the Holy Spirit," in Mirror to the Church, ed. Monica Furlong (London: SPCK, 1988), 125-139.

${ }^{815}$ Keith Warrington, Discovering the Holy Spirit in the New Testament (Peabody: Hendrickson, 2005).

${ }^{816}$ Ibid., 7-8.
} 
the earliest twentieth-century Pentecostals perpetuated such a powerful social message and influence, gathering and enfranchising the lowest of classes into a revitalized sense of family. ${ }^{817}$

Finally, the Spirit becomes the pedagogical center of key for hermeneutics within this Pentecostal fellowship for the reading of the biblical text in this pneumatic community. ${ }^{818}$ Ultimately, at the end, pneumatology and the scriptural community interweave in Pentecostal practice illustrating the role of the Spirit within family community. What Kenneth Archer has accomplished has been the unpacking of the sense of communal hermeneutical "self-understanding" within earliest Pentecostalism demonstrates the importance of pneumatological centrality for the believer, even to the study of scripture. ${ }^{819}$ Howard Ervin called this the "pneumatic exegesis" - the communal Spirit functioning as the proverbial Bible study leader. ${ }^{820}$ In this setting, the scriptures are read in light of scriptures providing a sort of self-invigorating exegesis based on the innercontextuality of the text, thus transcending a system of "proof texting." This Spiritled approach goes ahead to what Archer calls the central narrative convictions as "repetitive themes, aspects of narrative time, plot development, and characterization." 821 Archer rightly demonstrates that this early pneumatic community acknowledged the

\footnotetext{
${ }^{817}$ On the gathering of the lower classes of society into the Pentecostal paradigm, see Robert Mapes Anderson, Vision of the Disinherited: The Making of American Pentecostalism (Eugene: Wipf \& Stock, 2006); Sjorup, "Pentecostals."

${ }^{818}$ Helpful is Land's fundamentalist-critical "Spirit-Word" understanding of scripture where hermeneutical pressure is not applied solely to the Bible, but to the Spirit behind the text and the Spirit present in the spoken Word. Land, Pentecostal Spirituality. As well, see Kärkkäinen and Yong, eds., Toward a Pneumatological Theology, ch. 1.

${ }^{819}$ Kenneth Archer, A Pentecostal Hermeneutic for the Twenty-First Century: Spirit, Scripture, and Community (New York: Continuum, 2004), 2. See also his Archer, "Pentecostal Story."

${ }^{820}$ Ervin, Howard, "Hermeneutics: A Pentecostal Option." In Essays on Apostolic Themes: Studies in Honor of Howard M. Ervin. ed. Paul Elbert (Peabody: Hendrickson, 1985), 23-35.

${ }^{821}$ Archer, A Pentecostal Hermeneutic for the Twenty-First Century, 114-118.
} 
powerful authority of the Spirit to interpret the scriptures in Spirit-filled community. That is why Archer suggests, "For Pentecostals of all generations, the issue of biblical hermeneutics always arises whenever the doctrine of Spirit baptism is discussed." 822 Although evidence has suggested this strain of pneumatic hermeneutics has declined since the marriage of Pentecostalism to the NAE in 1945. Nevertheless, in contrast to Protestant and Reformed theology promulgating a "proof text" system, Pentecostals have historically emphasized a Spirit-led hermeneutic where the pressure was put on the Spirit and the Spirit in community to lead the reader to the central narrative passages in the biblical text. ${ }^{823}$

\subsection{The Holistic Spirit}

Our third theme of Pentecostal experiential pneumatology arrives in the form of the holistic Spirit. We may define this as the Spirit's life pervasive throughout all of existence - in healing, worship, creational life, and every imaginable avenue possible. Yet what are the elements of the holistic Spirit in Pentecostalism? Many examples of Pentecostals attempting to construct such a widespread pneumatology exist. For instance, illustrative of this is Kärkkäinen's engaging pneumatological study of Wolfhart Pannenberg. ${ }^{824}$ Here, Kärkkäinen attempts an engagement of pneumatic discourse outside the Pentecostal tradition - in this case - that of Pannenberg's landmark work culminating

822 Archer, "Pentecostal Story," 36.

823 Archer, A Pentecostal Hermeneutic for the Twenty-First Century, 74, esp. chap. 4.

${ }^{824}$ Kärkkäinen, "The Working of the Spirit of God in Creation and in the People of God." 
in his massive three-part Systematic Theology ${ }^{825}$ Following this cross-traditional analysis, Kärkkäinen offers both a dialogue and critical response to Pentecostal pneumatology based on Pannenberg's construction. In praise of Pannenberg, Kärkkäinen writes that he is a unique contributor for renewed Pentecostal pneumatology in a number of ways. First, Pannenberg's systematic pneumatology is not a venture divorced from the remainder of his overarching theology. That is to say, Pannenberg constructs a pneumatology throughout his entire theology. Kärkkäinen writes, "[H]is doctrine of the Spirit is interwoven with every major locus of his systematic theology, especially with God, creation, human beings, Christology, the Church, and eschatology." ${ }^{826}$ Thus Pannenberg offers a theological model for constructing pneumatology in an ongoing fashion throughout rather than a separate entity from the remainder of theology. Secondly, and on a more analytic level, Kärkkäinen argues that a "subjectivization," or separation of pneumatology from the remainder of theology and life in the Middle and Reformation Ages, has continued in the contemporary Spirit tradition throughout Christian theology, even at times within Pentecostalism. Kärkkäinen, in concluding, offers a helpful suggestion that Pentecostal pneumatology must never be separated from the whole of its theological operation; but it must span the whole with integrity.

Kärkkäinen has shown a more holistic approach by Pentecostal pneumatology in late modern scholarship. Exemplified by Kärkkäinen's engagement of Pannenberg, Pentecostal theology has engaged in more excelled dialogues with Protestants who are

\footnotetext{
${ }^{825}$ Pannenberg's theology has emerged as a formidable discussion partner for Pentecostals. His "force field" theory of the Spirit, while challenging to often dualistic (in/out; here/there) Pentecostal pneumatology, makes new room for creative theological imagination.

${ }^{826}$ Kärkkäinen, "The Working of the Spirit of God in Creation and in the People of God," 18.
} 
quickly recontextualizing the role of the Spirit in theology. ${ }^{827}$ This is possibly no truer than with its engagement of the theology of Jürgen Moltmann. Moltmann, above all, seems to have captured the attention of the Pentecostals. But why is this the case? For sure his reimagination of the Spirit in the realm of all of life through the kenotic pneumatology has given Pentecostals a conversational partner outside its walls to develop its pneumatology. Pentecostals have engaged Moltmann's pneumatological texts, primarily The Spirit of Life, The Future of Creation, and God in Creation, each making important cases for a pneumatology of the world similar to that of the earlier Hollenweger. ${ }^{828}$ These dialogues have erupted to bring forth diverse and novel imaginations of the Spirit outside of ecclesiology in PC theologies.

We find a form of this holistic pneumatology in Pentecostal worship expression. Daniel Albrecht has examined such a pneumatology in his text on holistic Pentecostal worship practices. ${ }^{829}$ Using three communities as case studies, Albrecht suggests that part of PC spirituality and pneumatology is inherently holistic, especially in terms of communal worship. For PCs, the Spirit's immanence in worshipful ecstasy in charismatic community makes this possible. This is true on many levels: the social, theological, psychological, and physiological. Albrecht writes, "Pentecostals seek to worship their God with their whole being. They have intuitively presented their bodies, their physicality, as instruments of worship. They seek to move with the Spirit, but not as incorporeal selves. Pentecostals experience God as embodied people, propelled by the

\footnotetext{
${ }^{827}$ Such as the case in Medina, "Jürgen Moltmann and Pentecostalism(S)".

${ }^{828}$ Moltmann, The Future of Creation; Moltmann, The Spirit of Life; Moltmann, God in Creation.

${ }^{829}$ Albrecht, Rites in the Spirit.
} 
Spirit and by their songs. ${ }^{" 830}$ Albrecht's work illustrates some important points regarding holistic worship. First, PC worship and Spirit-filled experience, deeply indwelling each other, offers the worshipper a posture that includes the entire body transcending simply the soul and spirit. Worship, therefore, is seen not only in terms of what is taking place in the heart and soul, but a complete surrender of the personhood under the Lordship of Christ. Secondly, this holistic form of Pentecostal worship makes room for mystical pneumatology. That is, the Pentecostal Spirit that engenders worship is by no means cognitively understandable evidenced by the widespread practice of glossolalia by PCs. This holistic worship immerses the entirety of their being into the presence of God through the act of worship as God completely takes over, even if it lacks cognitive sense. $^{831}$

The holistic Spirit continues to emphasize a practice of the Spirit's healing and power giftings in the contemporary world. On this, Clark Pinnock has suggested there remains a pneumatological hole that has been left in the wake of Reformation and Protestant theology. ${ }^{832} \mathrm{He}$ contends that while the emphasis of the Reformation was rightly on the forensic justification from sin and iniquity, what remains elusive is often a theology of healing appearing like that of the Kingdom ministry of Jesus found in the gospels. The gospels portray over and over a picture of the spiritual realm with an emphasis on the physical: healing, casting out legions, speaking to demons, and feeding crowds. In the spirituality of the gospels, the physical is not only connected but

\footnotetext{
${ }^{830}$ Ibid., 193.

831 This is the overarching point of Simon Chan's understanding of Pentecostal worship in Chan, Spiritual Theology, 38.

${ }^{832}$ See Macchia's analysis of Pinnock’s pneumatology in Macchia, "Pinnock’s Pneumatology," 168.
} 
eventually gets affected by the spiritual realm. Frank Macchia picks this important point up in reviewing Pinnock's pneumatology. Macchia claims that this forensic declaration found in the Reformation does "nothing at all directly about the power of sin and its destructive influences among on us, nor about the healing we so desperately need." ${ }^{\prime 33}$ What Pentecostal pneumatology brings to the table is a message of the gospel with regards to physical, emotional, and psychological healing. For in Christ's own Kingdom, exemplified by the Pentecostal outpouring, charismatic gifts are given to people for service and power to do the same ministry Jesus did. Not only does Christ redeem his church, he equips it with power to continue his ministry of healing. With this bridge made, the connection between the charismatic Christ and the charismatic church is found in Acts and, in Macchia's words, "is assumed without question." ${ }^{, 834}$ Macchia makes the case that this charismatic connection is in essence the central key to the preaching of the apostolic message. ${ }^{835}$

Thus, the Pentecostal tradition has attempted to pick up these important healing ministries of the holistic Spirit. This emphasis on physical healing in Pentecostalism goes back to its emergence and has been the métier of Pentecostal spirituality and practice undoubtedly from the primitive days of Parham and Seymour. Some of the earliest historical examples even did so in harmony with medicine practices of the day. Early Pentecostals, such as the Divine Healing movement, were not always in complete reaction to the medical community with its practice. Evidence of many early Pentecostal

\footnotetext{
${ }^{833}$ Ibid., 168.

${ }^{834}$ Ibid., 171.

${ }^{835}$ Macchia writes concerning this Charismatic structure, "[W]ithout this charismatic structure, preaching tends to become intellectualistic and abstract. In the Protestant focus on the Word of God, pneumatology has tended to be dominated by the exposition of the biblical text and the inward illumination of the text in the mind of the believer." Ibid.
} 
faith healers are that they considered healing by medical means useful as a valid expression of healing. ${ }^{836}$ Yet this is not to take away from the sense of the miraculous within Pentecostal faith and epistemology. For in the Pentecostal healing theology there is implied a pneumatology inclusive of the entire physical human personhood. Hollenweger extended this holistic healing motif in a 1981 article ${ }^{837}$ Within, Hollenweger argues there remain three main healing aspects of the Spirit: ecclesiological, cosmological, and the healing and re-creation within creation. Thus, Hollenweger extends the healing motif in Pentecostalism to issues of the church, the world, creation, and play.

Returning to Kärkkäinen's historical/theological critique of Pentecostal spirituality based on Pannenberg's approach, we discover promising potentials for a stronger holistic pneumatology in conversation with science. Kärkkäinen alludes that the most helpful contribution in Pannenberg's vision is that, again, of what he calls a "holistic, comprehensive approach," which includes most importantly for our discussion, creation and science ${ }^{838}$ This pneumatological integrity, made real by eschatological consummation, is what Kärkkäinen believes to be "the leading thematic feature of Pannenberg's pneumatology." ${ }^{839}$ Yet Kärkkäinen takes Pannenberg to task by offering a critique of his theology in lacking any pneumatological comprehension of physical healing. Perhaps in Pannenberg's lack of interaction with non-Europeans it might be clear

\footnotetext{
${ }^{836}$ As evidenced in DeWalle's well-written historical analysis of the Divine Healing movement. While they viewed medicine as being helpful, they were rather doubtful as to the ability of medicine to deal with the deeper issues of human depravity, such as sin. See Van De Walle, "Cautious Co-Belligerence?: The Late Nineteenth-Century American Divine Healing Movement and the Promise of Medical Science," in The Spirit Renews the Face of the Earth, ed. Amos Yong (Eugene: Pickwick, 2009), 53-73.

${ }^{837}$ Walter Hollenweger, "Towards a Church Renewed and United in the Spirit," in The Church is Charismatic, ed. Bittlinger Arnold (Geneva: WCC, 1981), 21-28.

${ }^{838}$ Kärkkäinen, "The Working of the Spirit of God in Creation and in the People of God," 25.

${ }^{839}$ Ibid., 28.
} 
as to why he has lacked interaction, conversation, and awareness of the PC traditions. So then, what can PC movements take from him? Kärkkäinen argues a more "holistic, allembracing, historically anchored doctrine of the Spirit." 840 Illustrative of this holistic pneumatology is seen in the overall work of Yong, who brings pneumatology into analysis with Philip Clayton's emergence theory, giving interesting insights into continued possibilities between Pentecostals and the sciences. ${ }^{841}$

But is this only the case with worship in holistic Pentecostal pneumatology or are there other touchpoints within we can trace a holistic understanding? As mentioned in chapter 3, Pentecostal spirituality often thrives in locations alongside liberation theology and practice. Perhaps a holistic comprehension of salvation is exemplified in this intersection of Spirit-living and social justice within liberation theology in many parts of the world. For instance, we find the theme of pneumatological expression providing a "return of voice" to voices silenced by colonialism, oppression, and injustice, as argued by Andrea Hollingsworth. ${ }^{842}$ The Spirit, therefore, plays a crucial role, among other things, in releasing the oppressed not only from spiritual bondage but material and structural bondage. Furthermore, the work of Leonard Lovett has illustrated a Pentecostal pneumatology for the purposes of giving people of color a sense of spiritual and liberative freedom in what he calls a "pneumatological liberation theology." ${ }^{\circ 43}$ Reflecting on his own history, Miroslav Volf reminds us in his study on his homeland Yugoslavian

\footnotetext{
${ }^{840}$ Ibid., 34.

${ }^{841}$ Yong, "Rûach, the Primordial Chaos, and the Breath of Life."

842 This theme is observed again in the intersection of feminist theology and pneumatology. See Hollingsworth, Spirit and Voice.

${ }^{843}$ Leonard Lovett, "Black Origins of the Pentecostal Movement," in Aspects of Pentecostal-Charismatic Origins, ed. Vinson Synan (Plainfield: Logos International, 1975), 123-141; Leonard Lovett, "Liberation: A Dual-Edged Sword," PNEUMA 9.2 (1987), 155-171; Leonard Lovett, Kingdom Beyond Color: ReExamining the Phenomenon of Racism (Orlando: Higher Standard Publishers, 2004).
} 
tyranny that the Spirit is attempting to release the oppressors at the same time as the oppressed. $^{844}$

Glory and success are not always the Spirit's goal in the book of Acts. The community of suffering is the culmination of Martin Mittelstadt's classic study on Lukan pneumatology, which focuses both on the suffering and blessing lacuna in the Luke-Acts narrative, pointing to the Spirit's leading its community into both acceptance and rejection. ${ }^{845}$ Mittelstadt reminds us that the reality of rejection under the Spirit's guidance is seen in Luke's account as part and parcel of God's divine will ultimately serving to embody the gospel throughout the entire oikomene. ${ }^{846}$ Through Mittelstadt's literary analysis of six key Lukan texts (Luke 2:25-35; 4:16-30; 12:1-12; Acts 4-5; 6-7; 20:1835), this pattern of acceptance and rejection is seen over and over again. The Spirit leads people into suffering and persecution as well as acceptance. Mittelstadt contends that Pentecostal theology often inadequately understands the dynamic relationship of Spirit to body_or what Russell Spittler called "Corinthian Spirituality." ${ }^{947}$ Here, in this paradigm, the Spirit and suffering are not mutually exclusive.

Pentecostal scholarship has of late also become much more acquainted with the pneumatological traditions outside Luke-Acts. Evidenced by Blaine Charette's thoughtful

844 Miroslav Volf, Exclusion and Embrace: A Theological Exploration of Identity, Otherness, and Reconciliation (Nashville: Abingdon, 1996).

${ }_{845}$ Mittelstadt, The Spirit and Suffering in Luke-Acts.

${ }^{846}$ Mittelstadt writes in his introduction that the gospels of Luke and Acts offer, not a triumphalism of the Spirit, but rather "acceptance and rejection, triumph and tragedy." Ibid., viii.

${ }^{847}$ Spittler defines "Corinthian Spirituality" within Pentecostal currents as "human nature that makes a principled exaggeration of the worth of the Spirit over the body." Russell Spittler, "Corinthian Spirituality," in Pentecostal Currents in American Protestantism, eds. Edith Blumhofer, Russell Spittler, and Grant Wacker (Urbana: University of Illinois Press, 1999), 3-19 (4). 
study on Matthean pneumatology is case in point. ${ }^{848}$ Utilizing a fresh biblical exegesis of the gospel of Matthew, Charette recognizes the tendency towards Luke-Acts and the potential problems of Pentecostalism's overutilization of Luke-Acts. He writes, "When it comes to the theology of the Spirit presented in the Gospels, Matthew and Mark are generally relegated to a secondary position in favour of Luke and John." ${ }^{849}$ Charette contends Matthew's pneumatology offers Pentecostalism a much-needed corrective in regards to the Spirit's role in cosmic redemption and eschatologically in restoring creation. ${ }^{850}$ But it is Pentecostalism's marriage to dispensationalism that has made it difficult for it to be informed by Matthean pneumatology, Charette argues. Ultimately, seeking to reshape Pentecostal scholarship, he suggests Matthew's pneumatology is “a proper enthusiasm for the activity of the Holy Spirit [and] must include a longing to be transformed by that holiness with which the Spirit is identified." 851 Thus a revigorated reading of Matthew's pneumatology will offer a more cosmologically rich soteriology.

\subsection{The Spirit of Eschatological Mission}

Finally, we turn to our last theme in Pentecostal pneumatology in the Spirit of eschatological mission. Pentecostalism was not born in a historical bubble. Yet, in its eschatological zeal for the imminent return of Christ to redeem the church and judge the world, Pentecostalism quickly formed a bubble. Historically, the primitive early-

\footnotetext{
${ }^{848}$ Blaine Charette, Restoring Presence: The Spirit in Matthew's Gospel, JPTSup, vol. 18 (Sheffield: Sheffield Academic Press, 2000).

${ }^{849}$ Ibid., 11 .

${ }^{850}$ Ibid., 12-15, 143.

${ }^{851}$ Ibid., 145.
} 
twentieth-century Pentecostals were both restorationist in theology, conceptualizing their movement as a fresh expression of the utopia of the early church, and deeply eschatological, expectant of the return of Christ at any moment's notice as the Spirit falls on his people. ${ }^{852}$ To put simply, they were a people of idealism and expectancy, desiring a return of Christ by focusing on reconstituting the spirituality of the pristine early church. This eschatological bent has been long established. ${ }^{853}$ William Faupel writes about this, "As the movement neared the turn of the century, expectations arose that God was about to restore apostolic authority and power to the church to enable it to accomplish his endtime purposes." ${ }^{\prime 54}$ In this expectancy, the missiological implications of the narrative of the book of Acts have deeply informed this motif. ${ }^{855}$ The Spirit of the life of Jesus and the book of Acts was in this way, "theirs." Today, in broad terms, Pentecostals are widely more aware and comfortable with discussing the Spirit's role outside its own movement and outside the setting of eschatology. Evidence of this is found in Pentecostal scholar Stanley Burgess's classic three-volume study, The Holy Spirit. ${ }^{856}$ In setting out what few have done before, Burgess traces the development of the doctrine of the Holy Spirit from the early church to the Reformation through a Pentecostal lens. His work will be discussed for decades to come. Burgess, in his careful historical exegesis, isolates key

\footnotetext{
852 On the eschatological Spirit, see Gelpi, The Divine Mother, 66-75.

${ }^{853}$ Faupel, The Everlasting Gospel. In particular, chapter 4, "The formation of Pentecostal Thought," Faupel uncovers the forces behind the development of Pentecostal theology at the end of the eighteenth century. Some of these forces are clearly the turn to premillenial theology, a turn to the apostolic church and tradition (restorationist), and an eschatological expectancy of the return of Christ. For other helpful historical notes on this topic, see Anderson, Vision of the Disinherited.

${ }^{854}$ Faupel, The Everlasting Gospel, 114.

${ }^{855}$ Robert Gallagher and Paul Hertig, eds., Mission in Acts: Ancient Narratives in Contemporary Contexts (Maryknoll: Orbis, 2004).

${ }^{856}$ No doubt others, such as Yves Congar, have attempted such studies. Burgess's perspective as a Pentecostal will yield much in attempting to understand Pentecostal pneumatology in his Burgess, The Holy Spirit.
} 
themes which play well into Pentecostal understandings of the roles of the gifts of the Spirit in charismatic community.

Pentecostals have always identified themselves in some sense as otherworldly. Cheryl Sanders appraises the life and culture of African-American PCs who readily found themselves in the slave trade in the West, yet at the same time being pulled by their spirituality to "be in the world, but not of it." ${ }^{\text {" }} 857$ This has long been a strong emphasis in all Pentecostal practice - to be in the world but separate from it. There is clearly a strong eschatological framework for this theology. Historically, PC theology and practice have a long precedent of seeing the message of the gospel spread in various ways in light of the expectancy of the return of Christ. Thus Pentecostals are a "sending" movement with a particular understanding of what this entails. Clark Pinnock's analysis concludes that, in regards to this apostolic movement (a "sending" movement), the RCs have always perceived apostolic sending to be from the historical church (apostolic succession), Protestants have responded by situating their mission with the apostolic message (apostolic kerygma), and Pentecostals the apostolic spirit sending Spirit-filled people into the world ${ }^{858}$ Here we see a thread of the Spirit's missionary nature, bridging the apostolic message to areas where the gospel has previously been absent. Christ's own mission is the model of Pentecostal mission. Terry Cross reminds us that a Spirit ecclesiology (pneumatological ecclesiology) such as this will ultimately rely on this missionary nature

\footnotetext{
${ }^{857}$ Cheryl Sanders, Saints in Exile: The Holiness-Pentecostal Experience in African American Religion and Culture (New York: Oxford Universe Press, 1996).

${ }^{858}$ See Pinnock's assessment of Pentecostal ecclesiology which readily touches on many pneumatological issues, Pinnock, "Church in the Power of the Holy Spirit," 156.
} 
of a God who sends his "sent ones" into the world. ${ }^{859}$ But as always, Cross reminds us that we must be hesitant to build any Trinitarian theology first on the Spirit and last on the Spirit. Trinitarian theology, must be, Trinitarian. This is a constant tension in Pentecostal pneumatology towards a Trinity that begins and ends with the Spirit.

Wonsuk Ma's helpful study suggests there were four main elements of this Spiritbased religion. These were moves "from marginalization to empowerment, an eschatological reminder of the return of Christ, a restorationist bent towards the early church, and a religion of experience." ${ }^{, 660}$ In light of our comprehension of the experiential drive of Pentecostal spirituality, we must see one of these foci in experiential Pentecostal pneumatology in terms of eschatological missionary fervor. ${ }^{861}$ To put simply, this was evidenced by the missionary activity that followed the experience of the Azusa Street revivals (1906-1909). This experiential driven religion pushed missionaries back to their homeland to spread the fires of this new life. Many socioeconomically powerless individuals found themselves inspired with vision to go and reach their homelands with the gospel. This Holy Spirit experience then led to missionaries filling the earth to prepare for the return of Christ by gathering the lower class, the least of these, and those who were not. Ma reminds us, in essence, as a movement, "Pentecostalism was a religion of the poor, not for the poor." 862

\footnotetext{
859 Terry Cross, “A Response to Clark Pinnock's 'Church in the Power of the Spirit', JPT 14.2 (2006), 175-182.

${ }^{860} \mathrm{Ma}$, "The Empowerment of the Spirit of God in Luke-Acts," 29.

${ }^{861}$ Donald Gelpi comments that the twentieth century has seen as "turn to experience in contemporary theology." Gelpi, The Turn to Experience in Contemporary Theology.

${ }^{862} \mathrm{Ma}$, "The Empowerment of the Spirit of God in Luke-Acts," 29.
} 
The social power of the revival in Los Angeles is still somewhat difficult to measure by its very scope. Its social implications, in light of the Acts 2 proclamation of the Spirit falling in the "last days," were gargantuan to say the least. William Seymour sought to create a venue and culture of worship for the disenfranchised in these last days. William Seymour's vision, alongside his team of ministers, was to see a place of worship where "the blood cleansed the color line" and all people of any color could worship God together. ${ }^{863}$ It was true that in this Pentecostal Spirit, "the Spirit made us one." ${ }^{864}$ The earliest Pentecostal understanding of community under the leadership of Seymour was one where color played little into the ability one had either to worship God or be embodied in Christian community. Most likely politics played a role in the split of "black" and "white" Pentecostalisms in the first twenty years of American denominational Pentecostalism. But the sociological power of blacks and whites worshipping together was both enigmatic and groundbreaking. And this could happen because, well, these were "the last days."

The social implications of a Pentecostal eschatological pneumatology have been freshly unpacked in recent years. For instance, Peter Althouse has conversed with Jürgen Moltmann's “transformationist theology” culminating Althouse's The Spirit of the Last Days. ${ }^{865}$ Furthermore, Althouse has examined the eschatological nature of the earliest Pentecostals in an in-depth dialogue with Steven Land, Frank Macchia, Miroslav Volf,

\footnotetext{
${ }^{863}$ Frank Bartleman and Vinson Synan, Azusa Street: An Eyewitness Account (Alachua: Bridge-Logos, 2006), 54.

${ }^{864}$ Ma, "The Empowerment of the Spirit of God in Luke-Acts," 32.

${ }^{865}$ Althouse, Spirit of the Last Days.
} 
and Eldin Villafañe. ${ }^{866}$ Althouse argues that while the earliest Pentecostals deeply expected the coming of Jesus, they have quickly "settled into the world." ${ }^{1867}$ Sadly, this elongated expectation has not generally resulted in a social and justice revival, or as Volf calls it "Hope Eschatology, in Pentecostal practice. ${ }^{\prime 868}$ But what is clear is the nature of the Spirit in eschatological fervor as having powerful social implications.

The Spirit, for the earliest Pentecostals, in essence, became the social power construct. This served as a centerpiece for preparing the world's harvest for Christ's return. And of course this is no doubt possible given that Pentecostals are the "people of the prophetically promised "latter rain," which meant that they fully recovered not only the Apostolic faith but also the apostolic power, authority, and practice. ${ }^{\prime 869}$ Sadly, at the time, this did not reflect either in a view of creation or the broader culture. Parham, before Seymour, held an overly pessimistic view towards creation and culture at large. ${ }^{870}$ As a formational piece in Pentecostal eschatology, Parham's premillenial dispensationalist and antiestablishmentarian views may have had long-term effects on the movements view of the Spirit outside the church (especially in creation). ${ }^{871}$ Yet each Parham and Seymour made their pneumatological influence felt on early Pentecostalism: it was Parham's doctrine of tongues and Seymour's social and racial doctrine that left a

\footnotetext{
${ }^{866}$ Ibid. Moltmann gives the foreword to Althouse's work. For an overview of Althouse's examination of the usefulness of Moltmannian theology for a Pentecostal context, see ibid., 2-4.

${ }^{867}$ Ibid., 1.

${ }^{868}$ On the "Hope Eschatology" of Miroslav Volf, see his Miroslav Volf, "On Loving with HopeEschatology and Social Responsibility," TR 7.3 (1990), 28-31.

${ }^{869}$ Archer, A Pentecostal Hermeneutic for the Twenty-First Century, 124.

${ }^{870}$ Althouse suggests that, in regards to Niebuhr's classic Christ and Culture discussion, the Pentecostals have tended to side on the "Christ against Culture." Althouse, Spirit of the Last Days, 22. Parham believed the biblical text to be the only basis in informing theological practice and theory. On Parham's theological legacy, see David Jacobsen, Thinking in the Spirit: Theologies of the Early Pentecostal Movement (Bloomington: Indiana University Press, 2003).

${ }^{871}$ On the antiestablishment nature of Parham's ministry, see Althouse, Spirit of the Last Days, 28-32.
} 
pneumatological contribution for both. Althouse writes concerning this difference with special attention to the sociological dimensions of Seymour's legacy, "Seymour believed glossolalia was the sign that the Holy Spirit was breaking down racial, gender and national barriers. ${ }^{1872}$ In this examination, Althouse argues that what is needed is a revisionist Pentecostal theology. This shift will come in moving to a more realized eschatology that focuses on the "already but not yet" nature of the Kingdom. He writes, "The coming kingdom creates possibilities for the present which have transformative and revolutionary power."${ }^{973}$

Roger Stronstad's seminal work gives insight into Pentecostalism's emphasis on capturing a theology of the Spirit upon all believers for the preaching of the message of Christ in the eschatological Spirit. ${ }^{874}$ The Spirit is not monopolized by clerical priests but wantonly falls on all followers to be divine advocates of God's Kingdom on earth. Recapturing the Hebrew prophetic tradition found, among others, in the book of Judges, Stronstad advances the case that Jesus, his disciples, and the converts following in the narrative of the Acts of the Apostles is the continued tradition of the prophetic eschatological Spirit-filled Messiah centered in Jesus (Luke 1-24). The disciples and their converts carry on this Spirit to be prophets in the world from Jerusalem to the ends of the world. The community of faith is therefore a community of prophets who call the world

\footnotetext{
872 Ibid., 35. On tongues as a sign or sacrament, see Macchia, "Tongues as a Sign."

${ }^{873}$ Althouse, Spirit of the Last Days, 11. Earlier in the prescript, Althouse writes, "In short, Pentecostal eschatology that saw the already/not-yet of the kingdom as transformation offered a theological framework that strengthened the inclusion of history and creation in the eschatological kingdom." Ibid., xii.

${ }^{874}$ Stronstad, The Prophethood of All Believers.
} 
to salvation and repentance ${ }^{875}$ Stronstad defines prophethood as "Luke's all-embracing, pervasive category for the people of God. ${ }^{876}$ Ultimately, in the line of Pentecostal pneumatology supported by a Lukan analysis, the Pentecostal tradition is a renewal of this idea and should be a constant reminder among non-Charismatic and non-Pentecostal traditions, says Stronstad. ${ }^{877}$ Some have even suggested that "prophethood of all believers" could be a sixth element of the "full gospel" message of the earliest Pentecostals. ${ }^{878}$ And a strong case has been made that this has, in a century's time, become "blurred" as an ideal of Pentecostal identity. ${ }^{879}$

Similarly, James Shelton's classic study on Lukan pneumatology, written on the heels of Dunn's critique, offers a redaction-critical approach to Luke's pneumatology ${ }^{880}$ For Shelton, Luke's distinctive eschatological pneumatology focused much more on the anointing and empowering of the Spirit on the believer for mission must be preserved and highlighted as opposed to simply reading it through the lens of the Pauline corpus. The soteriological role of the Spirit is left up to Paul's theology, through which the Spirit is so often interpreted in theological academia, contends Shelton. ${ }^{881}$ He suggests these distinctive NT pneumatologies must remain distinct, for "a purely harmonistic approach

\footnotetext{
${ }^{875}$ I am thankful to Steve Overman for the term "the democratization of prophecy" whereby all people are given the prophetic anointing through the fulfillment of Joel's prophecy. This is no doubt similar to Max Turner's usage of the term "democratization of the Spirit." Turner, Power from on High, 443.

${ }^{876}$ Stronstad, The Prophethood of All Believers, 114.

${ }^{877}$ Ibid., 123-124.

${ }^{878}$ Such as suggested in Kärkkäinen and Yong, eds., Toward a Pneumatological Theology, 58-59.

${ }^{879}$ Lederle and Clark, What Is Distinctive About Pentecostal Theology?, 76.

${ }^{880}$ Shelton, Mighty in Word and Deed.

${ }^{881}$ Shelton writes, "The views of Luke on the Holy Spirit, for example, should not be indiscriminately interpreted in light of Paul's presentation of the Spirit (or vice versa), because often they are addressing different themes concerning the Holy Spirit." No doubt this approach is similar to NT studies that are often blamed for emphasizing the diversity of the NT writers. Here, Shelton sees this approach as useful for his own analysis. Shelton, Mighty in Word and Deed, ix.
} 
to the pneumatologies of the various NT writers puts the unity of the church at risk." 882 That is to say, the church must strive to remain as diverse as the NT theologies and gospels remain diverse. "The early church insisted on four gospels," Shelton reminds us. ${ }^{883}$ This approach, unique in its ecclesiological implications, may seem problematic to many trained in the hermeneutical method intent on developing a singular "biblical theology," if you will.

Not mentioned above, yet very pertinent both to charismatic community and eschatological mission empowerment, is the prophetic tradition emphasized by Pentecostal spirituality. There continues a sense that the eschatological Spirit is awakening the church to newness, truth, and understanding; a prophetic Spirit often neglected, especially within Evangelicalism. Robert Menzies forceful and influential text, Empowered for Witness, offers a pneumatology of the prophetic tradition based on Luke's pneumatology that highlights this tradition. ${ }^{884}$ Writing largely as a collegial polemic in response to James Dunn's Baptism of the Holy Spirit, Menzies contends Luke's comprehension of the Spirit continues on the tradition both of the Hebrews and the intertestimental time period. Although his reading of the intertestimental period tends to be too broad for comfort, his defense of Pentecostal subsequent Holy Spirit baptism has made its mark and gone far to show Lukan pneumatology for being the unique account that it is. Menzies demonstrates that Jesus's ministry was both Spirit-led and prophetic. It is this same Spirit which lives in the believer at Pentecost and should continue subsequently in the Pentecostal movement today. Maybe the most important

\footnotetext{
882 Ibid., 3.

883 Ibid.

${ }^{884}$ Menzies, Empowered for Witness.
} 
element of Menzies prolific study is his reminder to Pentecostalism of the nature of prophetic activity both within pneumatology and within Pentecostalism.

\subsection{Summary}

In this chapter we have highlighted four themes of Pentecostal pneumatology: Spirit baptism, the charismatic Spirit, the holistic Spirit, and the Spirit of eschatological mission. As we saw in the three ecopneumatological constructions examined in chapter 4, we will now find that we have the building blocks for a Pentecostal ecopneumatology to complete a similar task. In identifying these themes, we can see that contemporary Pentecostalism has emerged into something new and something familiar. It has become more open to the world and taken on the colors, smells, and looks of the larger body of Christ. Yet there remains a strong distinctive flavor of historical Pentecostalism that shines through today, especially in its pneumatology. In many ways, modern Pentecostalism perceives itself as a reconstitution of a form of spirituality within the Christian tradition. And, clearly, this unique perspective has made it one of the most influential and successful forms of Christian life and practice in the twentieth and twentyfirst centuries. It is on these four themes that we will now be able to construct a view of creation that will eventually lead to a theology of praxis in regards to the earth. Now we will be able to more clearly define and articulate a Pentecostal pneumatological view of the earth and its subsequent implications. 


\section{Chapter 6 \\ TONGUES AND TREES-TOWARDS A GREEN PENTECOSTAL PNEUMATOLOGY}

"Where are the charismata of the 'charismatics' in the everyday life of the world, in politics, in the peace movement, and in concern for ecology?" 885 - Jürgen Moltmann

"No, it simply will not do, to dismiss the world in which we live, God's world, as if it held little significance for the Creator." ${ }^{886}$ - William and Robert Menzies

\subsection{Introduction}

As a final and constructive chapter we will flesh out the thesis with which we began. We will do this by developing a Pentecostal ecopneumatology in dialogue with the previous chapters. The force of this thesis will be advanced based on the accumulative forces of the previous chapters. After our introductory chapter 1, chapter 2, and chapter 3 undertook an examination of ecumenical Christian ecotheologies (RC, Protestant, Orthodox, and Ecofeminist) and PC ecotheology, respectively. Chapter 4 forwarded an engagement of three ecopneumatologists (Denis Edwards, Mark Wallace, and Sallie McFague) so as to better comprehend the nature of ecopneumatology and how it is being constructed in contemporary ecotheology for particular consideration within a Pentecostal context. Then, to identify a framework within which a Pentecostal

\footnotetext{
${ }^{885}$ Moltmann, Spirit of Life, 62, (italics mine).

${ }^{886}$ Menzies and Menzies, Spirit and Power, 166.
} 
ecopneumatology might be constructed, chapter 5 identified four themes of Pentecostal pneumatology: Spirit baptism, the Spirit of charismatic community, the holistic Spirit, and the Spirit of eschatological mission. After isolating these pneumatological themes, it is my contention that Pentecostal pneumatology proffers a helpful set of traditions, theologies, and constructions which promise a thoughtful assist in developing a Pentecostal ecotheology and praxis. Based on this, this thesis chapter will represent an attempt at Pentecostal ecopneumatology for the twenty-first century within the framework of our four identified themes of Pentecostal pneumatology.

As of yet, we have not been able to fully answer with integrity Moltmann's question presented at the beginning of this chapter. Where are the charismata in the PC practices regarding the various issues of ecology? At this point, the answer has begun to show itself more clearly. To put it in Moltmann's own language, we have "emerged as [we] walked it.. ${ }^{887}$ Now, after five chapters of requisite research, we are able to begin walking out a Pentecostal ecotheological tradition in a distinctively Pentecostal way. I contend this ecopneumatological development presented here will be part and parcel of a broader shift in Pentecostal theology that seeks to understand the breadth, depth, and influence of a Lukan-centered construction prominent in historical Pentecostalism. I will argue that this move in the direction of ecopneumatology will help to alleviate the sense of what I have called pneumatological myopia in chapter 5 . That is, it will redirect Pentecostal theology from an undeniable overemphasis on the process of the Spirit's role in individual salvation, regeneration, and empowerment to the neglect of ecological, social, and political soteriology. In this chapter I will suggest four essential elements of a

${ }^{887}$ Moltmann, Experiences in Theology, xv. 
twenty-first century Pentecostal ecopneumatology: (1) the Spirit baptized creation, (2) the charismatic creational community, (3) the holistic ecological Spirit, (4) and the eschatological Spirit of ecological mission. Along the way, I will utilize a biblical hermeneutical framework that will give a broader canonical understanding to the element discussed.

\subsection{Spirit Baptized Creation}

To begin we turn our attention to a central element of a Pentecostal ecopneumatology as a contextual and timely use of the Spirit baptism motif for a twentyfirst century ecological ethic. Here we will offer a theological/practical avenue for Spirit baptized communities to exhibit a more just and righteous relationship to the Spirit baptized earth. This will be constructed in conversation with the biblical text with particular attention to a Pauline commentary on the Pentecost Psalm (Ps. 68) in Ephesians 4:7-11. As French Arrington has rightly commented, "[T]he starting point and very foundation for Pentecostal faith and practice is the biblical text." ${ }^{988}$ Therefore, as with each correlative section, I will overview a biblical approach central to comprehending the particular theological strand and offer a Pentecostal construction. As such, in this section, I will begin by outlining the theology on the Spirit in the OT and NT.

God's Spirit is an essential character to the interplay of the Bible's narrative. There are two important aspects of the OT theology of God's Spirit that I would like to highlight: the OT creational and charismatic Spirit. We will look here at the creational

\footnotetext{
${ }^{888}$ French Arrington, “The Use of the Bible by Pentecostals," PNEUMA 16.1 (1994), 101-107 (101).
} 
Spirit and the charismatic Spirit in the next section. In the OT, rûach ("Spirit") is utilized on 377 particular occasions translated as "breath," "wind," "air," or "soul." 889 The term "Holy Spirit" is found only twice in the OT canon (Ps. 51:11-13; Isa. 63:10-11). One such reference is David's plea to God, "Do not cast me from your presence or take your Holy Spirit from me" (Ps. 51:13). God's Spirit and immediate presence within his people and creation are repeatedly portrayed as being unalterably interconnected ${ }^{890}$ From the establishment of the creation narrative, rûach "hovers" over a chaotic creation (Gen. 1:2). This same Spirit breathes new life into Adam's nostrils (Gen. 2:7). Both creation and humanity are portrayed as being imbued with the life-sustaining power of ruach. The Spirit soon takes on a new role in the story, blowing the floodwaters away from the deluge so Noah's boat could rest on dry land (Gen. 8:1). Thus, from the very onset, the image of wind/Spirit is portrayed as giving life, taking life, and saving life. Perhaps most importantly in this context is that God's rûach is immersing God's creation, giving it life. King David reflects, "Where can I go from your Spirit? Where can I flee from your presence?" (Ps. 139:7). He ponders again, "When you take away their breath, they die and return to the dust. When you send your Spirit (rûach), they are created, and you renew the face of the earth" (Ps. 104:4, 27-30). Donald Gelpi has reflected on these omnipresent pneumatological images, referring to the Spirit as a "scrutinizing omniscience. ${ }^{\prime 891}$ Moving towards the poetic literatures, the lines between humanity and nonhuman creation are increasingly blurred by means of this rûach force. For instance,

\footnotetext{
${ }^{889}$ Friedrich Baumgärtel, "Pneuma," in Theological Dictionary of the New Testament, eds. Gerhard Kittel and Gerhard Friedrich (Grand Rapids: Eerdmans, 1976), 332-368 (360).

${ }^{890}$ For a helpful overview of the OT's theology of the environment with respect to this interconnectivity, see Gene Tucker, "Rain on a Land Where No One Lives: The Hebrew Bible on the Environment," JBL 116.1 (1997), 3-17.

${ }^{891}$ Gelpi, The Divine Mother, 48.
} 
the author of Ecclesiastes writes, "Man's fate is like that of the animals; the same fate awaits them both: As one dies, so dies the other. All have the same breath (rûach); man has no advantage over the animal. Everything is meaningless. All go to the same place; all come from dust, and to dust all return. Who knows if the spirit (rûach) of man rises upward and if the spirit of the animal goes down into the earth?" (Eccles. 3:18). Denis Edwards speaks to this, writing, "All the wonderfully diverse things for the planet, all the entities that creep, crawl, run, hop, swim, and fly are brought to life by this Breath of God." ${ }^{892}$ Similarly, nonhuman beasts are portrayed as speaking on human terms such as the serpent in the garden and Balaam's ass (Gen. 3:1, 4; Num. 22-24).

The Spirit plays a similar yet different role in the narrative of the NT. The Septuagint (LXX), the Greek translation of the OT biblical text, translates the Hebrew rûach into the Greek pneuma. The NT writers perpetuated this, utilizing pneuma on nearly 250 occasions in speaking of God's Spirit. Of the 377 usages of rûach in the OT, 264 are ultimately translated as pneuma in the LXX. Pneuma takes on a number of meanings in the NT, in most cases being translated as "Spirit," and in another 49 cases as "wind." ${ }^{893}$ Joseph Fitzmyer helpfully points out that Mark has 6 references to the Spirit, Matthew 12, John 15, Luke 18, and Acts an overwhelming 57. ${ }^{894}$ These are important, for many of these references underscore the dynamic relationship of the pneuma to Christ. For instance, at Jesus's baptism, the Spirit descends on Jesus as a dove (Matt. 3:16; Mark 1:10; Luke 3:22). Eugene Rogers identifies this descending dove motif on the physical

\footnotetext{
892 Edwards, Breath of Life, 35.

893 E. Kamlah, "Spirit," in Dictionary of New Testament Theology, ed. Colin Brown (Grand Rapids: Zondervan, 1978), 690-692 (690).

${ }^{894}$ Fitzmyer, The Gospel According to Luke I-IX, 227.
} 
Jesus as the "paraphysical" Spirit hovering over the entirety of the natural order along with Christ. ${ }^{895}$ Similarly, Kilian McDonnell sees in this dove a cosmic element. For just as a dove brought good news of dry land to the floating ark in the flood, so the Spirit proclaims a baptized Jesus to a broken world ${ }^{896}$ But the pneumatology of the NT goes beyond a Spirit-Christology and includes broader cosmological dimensions. Perhaps the most remarkable aspects of NT pneumatology is Paul's connection of the pneuma to a suffering creation in Romans 8:22-28. In the context of the interceding Spirit, Paul writes, "For the creation was subjected to frustration, not by its own choice, but by the will of the one who subjected it, in hope that the creation itself will be liberated from its bondage to decay and brought into the glorious freedom of the children of God. We know that the whole creation has been groaning as in the pains of childbirth right up to the present time" (Rom. 8:20-22). Paul similarly expands a Christological approach to all of creation characterizing the cross as the overcoming of the death of the world "so that Christ may be all in all" (1 Cor. 15:22). John the apostle, will himself, while on the island of Patmos illustrate an eschatological vision where God tabernacles with creation in the new heaven and earth through the Spirit (Rev. 21:3).

As we discovered in the previous chapter, the apparent tensions between Lukan (charismatic and missional) and Pauline (soteriological and ecclesiological) pneumatologies have been a constant tension in Pentecostal theology. The Lukan narrative highlights a particular perspective. Within, John the Baptist marks the beginning of his own ministry by proclaiming to those he baptized that he did so with

\footnotetext{
${ }^{895}$ Rogers, After the Spirit.

${ }^{896}$ McDonnell, The Baptism of Jesus in the Jordan.
} 
water; but also one more powerful was coming who would baptize with fire and the Spirit of God (Luke 3:16). This baptism in the Spirit was a promised gift that Jesus was to bring to his disciples that the Baptist could not (Luke 24:49). This promise of a "gift" (Acts 10:45) is fulfilled at Pentecost where the disciples and those in the upper room are "filled with the Spirit" (Acts 1:5-2). Luke, Pentecostals claim, connects the Spirit's baptism to a "subsequent" experience called "Spirit baptism" (baptizein en pneumati). With a more predominately missiological bent, Luke reports that before his ascension Jesus commands his disciples to wait (paramenein) in Jerusalem for the coming Spirit to empower them in order to proclaim the gospel message to the ends of the earth (Luke 24:49). Acts 2 soon reports this powerful coming where those present would "receive power from on high" as earlier promised (Acts 1:2-8). As they are being filled with the Spirit, Peter addresses the onlookers out of Joel's prophecy (Joel 2). When asked what the onlookers should do, Peter tells them, "Repent, and be baptized every one of you in the name of Jesus Christ so that your sins may be forgiven; and you will receive the gift of the Holy Spirit" (Acts 2:38). Now, in the context of the coming of the Spirit, the anointed church, led by a preacher/fisherman, is empowered to preach the good news to the ends of the earth. Later readings from Acts point to a strengthened emphasis on a "subsequent" experience. For instance, Acts 8:15-17 appears to show a "subsequent" experience where new believers in Ephesus have believed and been baptized in water yet have not received the experience of Spirit baptism. Pointing to this, Pentecostals insist that a "subsequent" Spirit baptism experience is a necessary element of ordo salutis for the proclamation with power of the gospel. 
Paul, in contrast to Luke, appears to connect Spirit baptism to conversion, initiation, and water baptism. Paul writes, "The body is a unit, though it is made up of many parts; and though all its parts are many, they form one body. So it is with Christ. For we were all baptized by one Spirit into one body — whether Jews or Greeks, slave or free- and we were all given the one Spirit to drink" (1 Cor. 12:12-13). Paul further writes that there is "one baptism" in water and Spirit that every believer is privy to (Eph. 4:5). In his letter to the Romans, Paul writes that "hope does not disappoint us, because God has poured out his love into our hearts by the Holy Spirit, whom he has given us" (Rom. 5:5). Finally, in another letter, utilizing again the liquid metaphor, he writes, "Be very careful, then, how you live-Do not get drunk on wine, which leads to debauchery. Instead, be filled with the Spirit” (Eph. 5:15-18). Clearly, these pneumatological tensions must be addressed.

This is further complicated by the spectrum of OT and NT literature which suggests nuanced perspectives on the Spirit's purpose and presence both in the world and in the community of faith. While Spirit baptism is foreign (linguistically speaking) to the OT, it is surely conceived within it. But is there a connection in the NT between the Spirit and creation, such as the OT going beyond a pneumatology of ordo salutis and missiological empowerment described by Paul and Luke, respectively? As we have seen, the OT has a more developed creational theology in terms of the relationship between rûach and creation than does the NT. But does this mean there is no pneumatological creation language in the NT? Kirsteen Kim speaks rather drably about this in her most recent pneumatological work, writing, "Biblical scholars agree that there is no passage in 
the NT in which the Spirit of God appears as working in the entire creation. ${ }^{\prime 897}$ Others, such as Eduard Schweitzer, have pointed to a seemingly unrelenting difference between OT and NT pneumatology. Schweitzer argues, based on the language of the texts, that there is an irreconcilable chasm between the OT rûach in creation from the NT pneuma that came on believers at Pentecost. ${ }^{898}$ C.F.D. Moule similarly takes the view that Christos and Logos are cosmic in scope in the NT, but the Spirit is not. ${ }^{899}$

There is another side to this, nonetheless. Others, such as Moltmann, have keenly observed an important connection between the OT and NT Spirit narratives. Moltmann conceptualizes the continuity between the two testaments in speaking of the "spirit of life" which, at the same time, both gives live to creation and empowers the believer. ${ }^{900}$ This, for Moltmann, is the same Spirit doing two different works between the creational and charismatic. Denis Edwards, in examining Basil's pneumatology, has carefully shown the same continuity between the OT and the NT pneumatologies. ${ }^{901}$ So where might we discern a pneumatological approach to creation in the NT? Perhaps Clark Pinnock's words best describe the situation: "The role of the Spirit in creation, for example, is crucial theologically but not often or much discussed in the scriptures. Nevertheless, it is important to draw out the truth, even if lightly attested. The Bible may

\footnotetext{
${ }^{897}$ Kim, The Holy Spirit in the World, 20.

${ }^{898}$ Eduard Schweizer, "On Distinguishing between Spirits," ER 41.3 (1989), 406-415. Thanks to Kirsteen Kim on this point in her Kim, The Holy Spirit in the World, 20.

${ }^{899}$ Moule, The Holy Spirit, 19-21.

${ }^{900}$ Moltmann, The Spirit of Life.

${ }^{901}$ The overall theme of Edwards, Breath of Life.
} 
be like the fish that, when asked to describe its environment, neglected to say much about the water. ${ }^{902}$

I contend this pneumatological lacuna is filled in the "descent" of the Spirit in the Pauline writing of Eph. 4:7-11, a reading that will have clear implications for both a pneumatology of creation and a Pentecostal ecopneumatology. I claim, in light of the Ephesians text, a theological connection between pneuma (the image of Spirit baptism in Acts 2) and the broader creational setting based on Paul's rabbinic reflection of the Pentecost Psalm (86). This will not only bridge a gap between OT and NT Spirit narratives regarding creation but offers Pentecostal theology a way to discuss creation pneumatologically.

Ephesians 4:7-11 has solicited some rather contentious debates in recent years. Paul, discussing Christ's ascent and descent to and from the heavenlies, is readily believed to be a sort of rabbinical conversation with Psalm 86, a traditional Psalm of Pentecost. Recent scholarship on Ephesians has considered again the nature of what descent Paul speaks of, suggesting Paul is perhaps speaking of the descent of the Spirit at Pentecost described in Acts 2. There have been a number of interpretations of this descent. Some have suggested that this descent was Christ's incarnation in the flesh while others that it was his descent to hell after his death on the cross. ${ }^{903}$ Yet, in light of renewed Ephesians scholarship, a new school has suggested an alternative interpretation

\footnotetext{
${ }^{902}$ Pinnock, Flame of Love, 11, (italics mine).

903 One such is J. Clifford Hindley, "The Christ of Creation in New Testament Theology," IJT 15.3 (1966), 89-105.
} 
suggesting that this descent is the descent of the Spirit at Pentecost. ${ }^{904}$ The argument follows that Paul seeks to, in the Ephesians text, create a contrast between Moses's mountaintop experience in the OT Pentecostal narrative and the Pentecost event described in Acts 2 by using an OT Pentecostal Psalm. This view, supported by W. Harris, seeks to parallel Moses's ascent to the mountain to bring the words of God down in his descent to that of Christ ascending to heaven and descending in his Spirit at Pentecost. ${ }^{905}$ George Caird agrees with this thesis, further suggesting that Paul takes a traditionally Jewish Pentecostal Psalm relating to Moses and spins it as a Christian Pentecostal Psalm. Caird writes that in doing this Paul is "celebrating the ascension of Christ and his subsequent descent at Pentecost to bestow spiritual gifts upon the Church." ${ }^{906}$ Others have come to a similar conclusion, interpreting Christ's descent in Ephesians 4:7-11 as that of the descent of the Spirit at Pentecost. ${ }^{907}$

In this fresh interpretation, Ephesians 4:7-11 turns out to be a distinctively pneumatological text about creation. The passage quickly notes, in a classic Pauline parenthetical phrase, that in his final ascent to heaven, Christ, "fills the whole universe [pas_-'all things']" (Eph. 4:10). Schnackenburg suggests in regards to the "filling" (pleroun) in this context, Philo would often use this to describe God's omnipotence and

\footnotetext{
904 This latter view is no better articulated than in W. Hall Harris, The Descent of Christ: Ephesians 4:7-11 and Traditional Hebrew Imagery (Grand Rapids: Baker, 1996).

${ }^{905}$ W. Hall Harris, "The Ascent and Descent of Christ in Ephesians 4:9-10," BibS 151.602 (1994), 198214.

906 George Caird, “The Descent of Christ in Ephesians 4:7-11," SE 2 (1964), 535-45 (541).

907 Others have been T.K. Abbott, The Epistles to the Ephesians and the Colossians, International Critical Commentary (Edingburgh: Clark, 1897), 115-116; Andrew Lincoln, Ephesians, Word Biblical Commentary (Waco: Word, 1990), 242-248; H. von Soden, ed. Hand-Kommentar Zum Zeuen Testament: Die Briefe an Die Kolosser, Epheser, Philemon: Die Pastoralbriefe, vol. 3 (Freiburg: Mohr, 1893), 135136. The argument was first proposed by Soden, received by Abboth, and reconstituted by Caird.
} 
omnipresence. ${ }^{908}$ Therefore, if Paul is speaking of the Pentecost event as the new school is suggesting, we are offered a pneumatological connection to creation and "all things" (Eph. 4:10). In light of this, this descent Paul speaks of is a Pentecostal Spirit baptism of the church and the whole universe. Furthermore, in this setting, Paul implies both an ecclesiological and perhaps an ecological interpretation of Pentecost Psalm 86. For, on one hand, it is at Pentecost that Christ fills his church with charismatic gifts. Yet, in one fell swoop, the Spirit "fills the universe" with Christ's presence through his Spirit ecologically. Although there are undoubtedly some problematic exegetical issues with this interpretation, it still retains intriguing implications for a connection between the Pentecost event, pneumatology, and a creational theology. ${ }^{909}$ And if this fresh interpretation holds its weight, Paul appears intent to show the church's filling with the Spirit connected to the filling of the whole universe with Christ's power and authority. That is, in one move, the Spirit empowers the church and fills "the whole universe" with his presence and authority through his Spirit.

What can a Pentecostal reading of the Spirit baptized creation do for a construction of PC ecotheology? Our survey of twentieth and twenty-first century Pentecostal pneumatologies (chapter 5) through Macchia, Menzies, Yong, and others elucidated a thematic highlight of PC theology: Spirit baptism. This Spirit baptism motif - the crown jewel of Pentecostalism - has shown itself to be appropriated metaphorically for a wide range of experiences previous to and outside classic

\footnotetext{
908 Similarly, regarding exegetical options for the meaning of "filling the whole universe," see Rudolf Schnackenburg, Ephesians: A Commentary (Edinburgh: T\&T Clark, 1991), 179.

909 For an illustrative examination of the textual and hermeneutical issues, see Harold Hoehner, Ephesians: An Exegetical Commentary (Grand Rapids: Baker, 2002), 532-533.
} 
Pentecostalism. The diversity of these Spirit baptism experiences have been best discussed in McGee's Initial Evidence. ${ }^{910}$ An evaluative summary would suggest that, at best, Spirit baptism carries with it a theological tradition that has fostered meaningful Pentecostal spirituality. At its worse, its usage has unintentionally alienated many nonPentecostals from both the Pentecostal and the Charismatic movements by dividing the truly spiritual from the outsiders. But it is still a powerful tradition that holds great value for Pentecostal communities. Simon Chan, on the importance of this doctrine for Pentecostals, writes, "If Pentecostals today are to recover the full-orbed Pentecostal reality of the first ten years, they will need to enlarge their understanding of key concepts

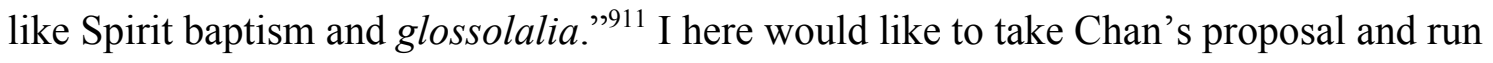
with it in an ecological dimension. In this Spirit baptized creation discussed in Ephesians 4:7-11, we find a reanimated metaphor to speak not only of the earth as the residence of the Spirit who "fills all things" (Eph. 4:10), but also of the Spirit's role in human empowerment to care for, protect, and defend the earth, fulfilling Christ's dream of creational Jubilee going beyond an ordo salutis overly focused on individualized salvation and exemplifies an earthen life entirely immersed in the Spirit in eschatological expectation.

The Spirit baptized creation thus draws on and emphasizes the hallowedness of all of God's creation. As we have observed, the biblical narrative of the creational imagery of the Spirit is almost entirely metaphorical (dove, wind, water). Spirit baptism is a similar metaphorical device. This is deeply important for our purposes on two levels.

\footnotetext{
910 McGee, ed. Initial Evidence.

911 Chan, Pentecostal Theology and the Christian Spiritual Tradition, 12.
} 
First, as Yong alluded, metaphors such as these (Spirit baptism) have the power to create something deeper within all of us. The image evokes a fresh awareness of that which was once unknown. Spirit baptism, as a picture, evokes an image of entire Spirit awareness in every recess of creation and the believer's life. Thus the Spirit baptized creation is one that is immersed in the waters of the Spirit's life. Analogically, it is arresting that the biblical narrative never utilizes technical language when referring to the personal God. It is always relational. God is the Father, our friend; a Mother caring for her young, a bird. Moreover, in terms of the Spirit, all of the available biblical metaphors (wind, fire, bird, breath) are all elements of the everyday human experience that they give little attention to. These metaphors are intended to point to something deeper in the everyday. As J. Rodman Williams reminds us, the emphasis on the Spirit baptism metaphor is that of complete and utter covering of being. ${ }^{912}$ Spirit baptized people are aware of a deeper presence in all entities. And it is only when humans are in touch with these metaphors that the omnipresence of God's Spirit can be grasped in its entirety. This metaphorical turn in the biblical witness draws attention to the different persons of the Trinity on a relational level: Father-God, Jesus-Brother, Spirit-Breath. It is through our relationship to the natural order that we can get a glimpse of the Spirit's being.

I would suggest that the relational language of the Trinitarian formula through the Spirit requires a new social dynamic between earthly creatures. The importance of this has been seen in the effect of pneumatology in the earliest stages of Pentecostal history. As is clear from a reading of early American Pentecostal history, the implications of Spirit baptism were sociologically groundbreaking. William Seymour, who envisioned

\footnotetext{
912 J. Rodman Williams, The Pentecostal Reality (Plainfield: Logos International, 1972), 12-13.
} 
Spirit baptism as a way of bringing peace between believers of all races, contended that the Spirit baptized practice could and should bring blacks and white together in worship. Ultimately, in contrast to a large portion of modern day Pentecostalism's emphasis on tongues as the initial sign of the Spirit baptism, Robeck reminds us that Seymour saw the primary gift of Spirit baptism as love. ${ }^{913}$ I would like to suggest this love-driven Spirit baptism can inform a Pentecostal ecological ethic based on Spirit baptized relationship. In this context the Spirit baptized believer loves and cares for the Spirit baptized creation based on the Spirit who indwells them both. Just as Seymour envisioned glossolalia as the breaking down of racial barrier walls between blacks and white, the Spirit baptized believer can make peace with the Spirit baptized creation. This breaks down the walls between human and nonhuman creation in a dynamic setting of the Spirit.

This similarly offers a theological motif that deconstructs inherent mores between men and women; the very critique ecofeminism has offered of Western patriarchal culture. In all of these contexts regarding creation, gender, and race, the Spirit baptized creation recaptures the call to a garden where the interconnected creation lives in harmony based on the Spirit's presence. In an Acts 2 paradigm where all flesh is filled with the Spirit and Christ is fully in "all and all" (1 Cor. 15:22), oppression and abuse of any kind is intolerable even while God insists on allowing these things to continue in giving humanity ability to have choice. But the Spirit yearns, it "groans" (Rom. 8:28), against these oppressive forces. In some cases, this breakdown of walls between human and nonhuman creation is exemplified in Pentecostal theology and practice. For instance,

\footnotetext{
${ }^{913}$ Cecil Robeck, "William J. Seymour and the 'Bible Evidence'," in Initial Evidence: Historical and Biblical Perspectives on the Pentecostal Doctrine of Spirit Baptism, ed. Gary B. McGee (Peabody: Hendrickson, 1991), 72-95 (81).
} 
snake handling, practiced in some Pentecostal communities, is a unique form of this broken wall of separation to which we are speaking. Creation can now, even the most dangerous of creation, exist alongside human creation in harmony and peace in the context of Christ's salvation (Mark 16). For a Pentecostal theology of snake handling is a redemption of the narrative of the garden where humanity was deceived by a serpent. Now, in light of a Pentecostal view of Spirit baptism, we are taken from being deceived by snakes to holding them and handling them.

This redemptive narrative of the reversal of the garden is clearly an important eschatological dynamic in this ecopneumatological construction. Frank Macchia has already connected Spirit baptism eschatologically to creation. He suggests, "Seen as an eschatological concept, Pentecost becomes a symbol, not only of the divine breath filling and charismatically empowering God's people, but also indwelling all of creation on the day....The kingdom thus centrally involves but also transcends the church." ${ }^{914}$ Macchia continues, "[T]he church is allowed to participate in, and bear central witness to, the final sanctification of creation." 915 Macchia seems to suggest that the Spirit empowers the church and "fills the universe" (Eph. 4:10) with power and authority in one movement at Pentecost. Here a eschatological "sanctification of creation" embodies what we might rightly call the transformatio Dei of creation. This transformation has a pneumatological basis. Jesus himself discussed how God's Kingdom was a sort of cleansing or sanctification: "If I drive out demons by the Spirit of God, then the Kingdom of God has come upon you" (Matt. 12:28). The Kingdom of God is adverse to all forms of evil:

\footnotetext{
914 Macchia, Baptized in the Spirit, 102-103, (italics mine).

915 Ibid., 86.
} 
spiritual, physical, and ecological. This same Kingdom further celebrates the year of the Lord that gives hope for wholeness, reconciliation, and peace to all (Luke 4:18). As Mittelstadt has shown, the time before the fulfillment of this hope, the Spirit would help Jesus's disciples suffer. ${ }^{916}$ This Spirit seeks to return just that Lukan emphasis of the Spirit and suffering to theology. In the same way, Christ's Spirit serves the same role in the suffering creation. Creation, before the culmination of all things, has the promise of God's Spirit to help it suffer during this period of ecological persecution. For truly a Spirit baptized creation is one where all creatures, both great and small, humans and dung beetles, have revitalized value and importance for God's created order even though they undergo suffering today.

A Spirit baptized creation forces a cosmological reinvention for Christian practice. For undeniably, in this context, based on the Spirit's life, humanity no longer can claim themselves as the central character in the story of creation. Rather, because of the Spirit's life in creation, humanity becomes a part of the broader creation story. God's Spirit becomes the life-giving power commonly to both humans and nonhumans. Clearly, care must be exhibited in stewarding the Spirit baptism motif appropriately. For Spirit baptism has been problematic in separating humans from nonhumans. Shane Clifton has suggested that Spirit baptism has largely been the force behind an ignorant ecological ethic. He writes, "[B]aptism in the Spirit facilitates the separation of the empowered believer from the world...[and] does little to encourage an earth affirming ecological ethos. ${ }^{917}$ Both points must be taken in their own light: Spirit baptism both has the power

\footnotetext{
916 Mittelstadt, Spirit and Suffering in Luke-Acts.

917 Clifton, "Preaching the 'Full Gospel' in the Context of the Global Environment Crises," 123.
} 
to separate the baptized from creation and has the potential to liberate believers into a new paradigm whereby the Spirit baptized church participates in the eschatological sunset of the new creation. In the same way Wallace spoke of the "Wounded Spirit," Pentecostals may speak of environmental disasters as "grieving the Spirit." In going back to the developmental stages of Larry Christenson's A Charismatic Approach to Social Action, social justice must be imagined as a fresh work of the Spirit. ${ }^{918}$ Thus, the environmental efforts to clean water sources and changing laws to protect forests can be given a context of the Spirit's larger efforts to author sustainability.

Finally, a Spirit baptized creation can contribute to the overarching efforts of Pentecostals (i.e. Amos Yong and Paul Elbert) to substantively enter into the science/theology dialogue. Spirit baptism implies that everything, even science, can be a work of the Spirit. As we saw in Denis Edwards's theology, the Spirit's role in creating space for creation to emerge or evolve is a distinct possibility. We see pneumatological approaches to this such as Yong's exegesis and usage of Philip Clayton's emergence theory. ${ }^{919}$ Edwards has also rightly shown that ecotheology at every stage of every generation has been deeply shaped by the knowledge of that generation. It is important to note Pentecostal theology was entirely formed and framed by the modernist dispute, which was driven almost entirely by the desire of the fundamentalists to defeat evolution in the public sphere. Historically, Pentecostals have for nearly a century been on the opposing side of the evolution/creationism debate, often locking arm-in-arm with fundamentalism on the issue of scientism and evolution. Being a "Johnny-come-lately" in

\footnotetext{
918 Christenson, A Charismatic Approach to Social Action.

919 Yong, "The Spirit and Creation."; Yong, The Spirit Poured out on All Flesh; Yong, "Rûach, the Primordial Chaos, and the Breath of Life."
} 
the creation/evolution dialogue, Pentecostalism, birthed nearly fifty years after Darwin's The Origin of Species (1859), have always struggled with the idea of evolutionary thought. ${ }^{920}$ No doubt a Pentecostal partnership with the NAE has done little to quell that commitment. And while the author cannot deal directly with the issue of evolution in this project (nor is his mind made up on the issue), an ecopneumatological pursuit very well may open doors for a more humble and appropriating response to evolutionary theory, creating space for greater comprehension on both sides.

\subsection{The Charismatic Community of Creation}

The second element of a Pentecostal ecopneumatology that I will develop here is that of the charismatic community of creation through a reading of both the OT and the NT. As there is a creational theme to the Spirit in the OT that we have discussed, there is also an important charismatic element. God's Spirit is introduced very early in the narrative of OT scripture and the life of Israel. Donald Gelpi, in illustrating the importance of the Spirit to the life of Israel, has gone so far as to suggest that rûach parallels Israel's "dawning of religious consciousness." ${ }^{.921}$ At the emergence of humanity, this Spirit is breathed into the nostrils of Adam (Gen. 2:7b). ${ }^{922}$ Later, in the Exodus account, the "burning bush" speaks to Moses as an image of God's Spirit with God's people (Exod. 3:2). God, in bringing his people out of bondage, will eventually Israel by his Spirit in a "cloud by day and fire by night" (Exod. 31:21-22). This image of cloud and fire,

\footnotetext{
${ }^{920}$ See the very helpful Norris, "Creation Revealed."

${ }^{921}$ Gelpi, The Divine Mother, 47.

${ }^{922}$ It has been suggested that this is a parallel to Christ's own breathing of the Spirit onto his own disciples in the passion narrative of John 20:22.
} 
representing God's presence with his people in the desert wanderings, continues throughout the Exodus narrative. As Israel develops their own communal identity, God's Spirit more clearly becomes the source of charismatic communal life. The Spirit inspires the creativity of Bezalel for the building of the sanctuary (Exod. 36:1). In the book of Numbers, God pours out his Spirit on the seventy elders to lead Israel in its time of need (Num. 11:16-17). A later story recalls how the same Spirit that had resided in Moses was transferred to Joshua (Num. 27:18). In the era of the judges, it is the Spirit that "came upon" Othniel, Gideon, and Jephthah as Israel's leaders (Judg. 3:10; 6:34; 11:29). Later, leaders such as Saul, David, and Elijah will be anointed and filled with God's Spirit for the purposes of leadership and prophetic utterance. In the Isaianic literature, it is the anointed coming Messiah (moshiach) who will come as a Spirit-anointed leader to bring peace to the earth (Isa. 42:1-5). This leader, in the words of Gary Babcock, is portrayed as the "agent of ethical renewal. ${ }^{"}{ }^{23}$ In other prophetic literature, with clear eschatological and political undertones, the Spirit serves as a renewer of the community of Israel from their spiritual death in the story of the valley of the dry bones (Ezek. 37:2-10). The communal nature of God's Spirit continues throughout other parts of the OT (see also Ezek. 37; Isa. 44:3; Joel 2:28). The OT biblical narrative thus fosters a double picture of the life of the Spirit as being the vivifying force of creation and the charismatic force of the people of God.

This OT theology of the Spirit, in nonsystematic style, is described by Kärkkäinen as that which "teaches about the Spirit through symbols and stories, and the accent is on

\footnotetext{
${ }^{923}$ Gary Babcock, Light of Truty \& Fire of Love: A Theology of the Holy Spirit (Grand Rapids: Eerdmans, 1997), 15.
} 
the work of the Spirit, in other words, spirituality." 924 This is the Spirit that brings life physically and spiritually to the people of God. Yves Congar has pointed to a tangible sense of the Spirit in the OT narrative. He writes, "It is a subtle corporeality rather than an incorporeal substance. The rûach/breath of the Old Testament (OT) is not disincarnate. It is rather what animates the body. ${ }^{, 925}$ But others, such as Moltmann, will see Pentecost as the culminating even of both the creative and charismatic pneumatological vision of the OT. Moltmann will point to the ultimate reality of Pentecost, the highest point in the church calendar and the history of salvation: Christmas - Good Friday_Easter-Ascension Day—Pentecost. ${ }^{926}$ Thus, a Pentecostal theology sees itself as the culminating event of God's inflowing Kingdom that is found in the OT. It is that Pentecost experience that is the basis for NT communal charismatic life. Reflecting on this, Donald Guthrie has rightly stated that these OT narratives "have significance for a consideration of the gifts of the Spirit in the NT church."927 Others, such as Pentecostal Ralph Martin, have drawn even further parallels in this regard. Martin has called Judges "the Acts of the New Testament" because of its emphatic portrayal of the Spirit empowering believers. ${ }^{928}$

Similarly, in the NT, the Spirit inspires, connects, and empowers the community of God in Christ's disciples. ${ }^{929}$ Eduard Schweitzer writes, "If we try to sum up what is central in the NT despite all the differences, we see that in it there is no doctrine on the

\footnotetext{
924 Kärkkäinen, Pneumatology, 23.

925 Congar, I Believe in the Holy Spirit, vol. 1 (3).

926 Ibid., 15.

927 Donald Guthrie, New Testament Theology (Downer's Grove: IVP, 1981), 511.

928 Roy Martin, The Unheard Voice of God: A Pentecostal Hearing of the Book of Judges (Blandford Forum: Deo, 2008), 4.

${ }^{929}$ Pneuma is used nearly 250 times in the NT narrative.
} 
Spirit, but rather that the Spirit is narrated as an event — as happening." "930 That is, the Spirit "happens" through the charismatic community in the NT. This "happening" is best illustrated in the Spirit-Christology of the NT. In his first writing, Luke expands a strong Spirit-Christology where Jesus is born in the power of the Holy Spirit by a mother, Mary, who is "overshadowed" by the Holy Spirit (Luke 1:35). ${ }^{931}$ Luke narrates that "the child grew and became strong in spirit" (Luke 1:80), was led into desert by Spirit (Luke 4:1-2), was led into Galilee "in the power of the Spirit" (Luke 4:14), confirmed as Son of God (Luke 3:22), and at death "gives up his spirit" (Luke 23:46). Truly, for Luke, Jesus is the continuation of the Spirit's work of God's mission in the world. ${ }^{932}$ In his second narrative, the book of Acts, the same Spirit who empowered and led Jesus empowers his disciples (Acts 1:8; cf. Luke 24:49) and the church to go "to the ends of the earth" (Acts 2:4-5). These disciples are portrayed as "full of the Spirit" as was Jesus (Acts 4:8; 6:3-5; $7: 55 ; 8: 29,39 ; 11: 24 ; 13: 9)$. Jesus lovingly pours out his Spirit from the Father upon the church (Acts 2:33). Here, "all flesh" is filled with God's Spirit who is the one who will guide the church (Acts $6: 10 ; 8: 29 ; 10: 19 ; 11: 12 ; 13: 2,4 ; 15: 1-21 ; 16: 6-7 ; 19: 21 ; 20: 22$ ). The first council illustrates the Spirit's continuing guidance as the Gentiles are included into the church (Acts 15). And finally, for Luke, it is the Spirit who pours out on Gentiles, such as the Samarian converts (Acts 8:14-17), Cornelius and the Gentiles (Acts 10:44-47; 11:17; 15:8), as well as some Ephesians (Acts 19:6). As with the OT, the Spirit also judges and can bring death as in the case of Ananias and Sapphira (Acts 5:3, 9).

\footnotetext{
930 Schweizer, "On Distinguishing between Spirits," 413.

931 The LXX translates Exod. 40:35 as episkiazo referring to the tent of meeting being "overshadowed" by the Spirit. The same word is used here and elsewhere in the Greek NT.

932 Kim, The Holy Spirit in the World, 16.
} 
This charismatic Spirit plays an important and illuminating role in the destruction of sociological walls in Luke's history of the church. God's Spirit redemptively breaks down false walls of separation for the purposes of reconciliation in Acts. For instance in the narrative of Pentecost in Acts 2, Luke tells us the Spirit brought together enemies, both "Arabs and Cretans" (Acts 2:11), to hear the proclaimed gospel of Christ during the feast of Pentecost. Another instance of this is Peter's rooftop soteriological vision which leads him to preach the kerygmatic message of grace to a humble God-fearing Gentile family (Acts 10). This illustrates a clear and new salvific in-breaking for not only the economy of salvation for the Jewish peoples, but more importantly for the Gentile world. Peter's vision of a "four-fold" sheet reflects the cosmologically centered nature of God's soteriological vision beyond the Jewish nation. This fulfils something important for the OT prophets. For the authors of the NT, Christ's Kingdom becomes the fulfillment of the anointed Messiah who, in Isaiah 11, creates a setting where "wolf will live with the lamb, the leopard will lie down with the goat" (Isa. 11:6). Thus, the coming of the Pentecost Spirit allows a place of peacemaking to be a new possibility.

Pauline pneumatology similarly addresses this charismatic community. For Paul, new believers are "new creations in Christ" (2 Cor. 5:17; "of the Spirit" in Titus 3:5). Eschatologically, Paul further envisions the Spirit as a down payment (arrabon) of what is to come (Rom. 8:23; 2 Cor. 1:22; 5:5; Eph. 1:13-14; see also Heb. 6:4). The Spirit is also a foretaste (2 Cor. 1:22; 5:22) of the incoming Kingdom. Ultimately, for Paul, it is the Spirit that creates community (Rom. 8:9) and marks it (Gal. 3:3). It is also the Spirit that makes intimacy of relationship possible (Rom. 8:15; Gal. 4:6; Eph. 2:17-18). In the context of dysfunctional church life, Paul more than once attempts to establish a sense of 
unity between the churches by utilizing the idea of the "gift of the Spirit" (Rom. 1:11;1 Cor. 1:7) as, in the words of Dunn, "common ground." ${ }^{933}$ Community is thus the new temple of the Spirit that has replaced the temple of brick and mortar (1 Cor. 3:16; 6:19). The Spirit gives the highest gift in love (Rom. 5:5; 15:30; 1 Cor. 13; 15:30; Phil. 2:1). Because of this, space must be made for the other in Christian community. Schweitzer comments on this: "Where the community is destroyed because it is thought that there is no room for the more conservative Peter alongside the more radical Paul and the more charismatic Apollos (1 Cor. 3:4, 17, 22), there God's Spirit is no longer present." "934 Thus, we see, in Paul's pneumatology, it is the Spirit that embodies the new temple, Jesus's body, the church.

To expand an ecological theology of the charismatic community of creation, let us return for a moment to the Greek notion of the oikos that we discussed in chapter 1. Interestingly, ecclesiology and ecology both find their meaning (conceptually and linguistically) in the Greek idea of the oikos, or "household." In regards to ecology, Ernst Haeckel conceptualized the natural world as a "household." Similarly in regards to ecclesiology, a number of NT writers utilized the notion of oikos to speak of the "household" of the church (1 Tim. 3:5, 15; Heb. 3:6). But after a study of the OT, we will speak here of creation and the church as the "households" of the Spirit. Just as the OT emphatically continues a theological tradition of the relationship of ruach to God's creation, the NT emphasizes a Spirit that has been poured out on all "flesh" (Acts 2:17).

\footnotetext{
933 James Dunn, Jesus and the Spirit: A Story of the Religious and Charismatic Experience of Jesus and the First Christians as Reflected in the New Testament (London: SCM, 1975), 419-425.

934 Eduard Schweizer, "What Is the Holy Spirit?: A Study in Biblical Theology," in Conflicts About the Holy Spirit, eds. Hans Küng and Jürgen Moltmann (New York: Seabury, 1979), xiii.
} 
While Pentecostal communities embody an ecclesiological model of Spirit-empowered witness whereupon each participatory member practices service within Christ's body (soma) on behalf of the world (cosmos), it is a broader connection of the charismatic church to ecological issues that needs to be made. To follow Luke's narrative in Acts, the church becomes by God's Spirit the living and fleshly second coming of Christ at Pentecost, perpetuating Christ's ministry on and towards earth. This ecclesiological second coming, the Spirit baptized community, continues to await the third coming of the returning Christ.

I suggest that this theology of a charismatic community can be extended as a bridge to envisioning ecological stewardship with the Spirit who is embodied in creation. That is to say, based on a holistic pneumatology of the church and creation, the wall of separation between human and nonhuman creation is in some way lessened by means of the Spirit who has empowered the church, and the Spirit who has "filled the universe" (Eph. 4:10). The charismatic community can, in this view, open their fellowship to the larger creation, ultimately creating a setting for a fully ecumenical fellowship. It was the French mystic Simon Weil who could not understand how the church could see itself as universal if creation was not included in its view of salvation. ${ }^{935}$ Yet, in a pneumatological context, this universality of God's fellowship is possible. For the church, as a Spirit baptized entity, is best understood as an appetizer, or preview of the Kingdom of God where peace and harmony are experienced and practiced by all (Isa.

\footnotetext{
935 "We have to be catholic, that is to say, not bound by so much as a thread to any created thing, unless it be to creation in its totality." Quoted in Weil, Waiting for God, 98. Thanks to Sallie McFague for this quote in her McFague, A New Climate for Theology, 33.
} 
11:6-9). As such, it will greatly remedy inadequate soteriologies that fail to grasp the Spirit's salvific role in healing the earth.

A theology such as this has been called on for some time. Hollenweger had called on Pentecostalism for a "theology of the whole" world, which he attempted to develop himself in regards to the whole created order. ${ }^{936}$ Amos Yong has likewise examined the creational implications of this theology of the charismatic community. Reflecting on the importance of Pentecostal pneumatology, Yong writes, "The theological gift of Pentecostalism to the church catholic, I suggest, is to contribute to the recent renaissance in pneumatology more specifically and in pneumatological theology in general." ${ }^{\prime 937}$ That is, for Yong, Pentecostalism offers back to the ecumenical community a revitalized pneumatology with a core theme of Jesus as the anointed one who brings peace, ending barriers of affliction prominent in this creational order. He continues on this: "Indeed, the arrival of the day of the Lord is a thoroughly pneumatological event that transforms all creation (Isa. 32:15-16) and affects even relationships between the wolf and the lamb, the leopard and the kid, the calf and the lion (cf. 11:6-9; 65:25). ${ }^{, 938}$ That is, Christ's Spirit anointing on the church and creation creates a context of peace-making. As we have discussed regarding early Pentecostalism, the basis of blacks and whites worshipping together at the Azusa Street revival was a pneumatological one. I would like to extend this peacemaking motif to a broader setting of creation. Just as the Spirit does not pour out only on those of a particular skin color or nationality, we have also seen that the Spirit

\footnotetext{
${ }^{936}$ Hollenweger, "All Creatures Great and Small."

${ }^{937}$ Yong, The Spirit Poured out on All Flesh, 25-28.

${ }^{938}$ Ibid., 95-96.
} 
pours out not just on a particular species (Acts 2:17b). ${ }^{939}$ The Spirit, pneumatologically speaking, is not a respecter of species. That is, the Spirit is not anthropocentric in any sense of the word; it is not human-centered. For this is a Spirit that comes to us as a dove, sometimes as water, and other times as wind. Obviously, it must be reminded that a clear difference in the role and giftings remain as to how the Spirit lives among human and nonhuman creation. Nevertheless, biblically speaking, in their own Spirit-filled way, each creature (human or not) plays its part in glorifying God. Have we forgotten that "the whole earth is filled with his glory" (Ps. 72:19)? And as creation and the church are open to the Spirit's life, peaceful transformation can break in. A charismatic creation theology allows a new context of peace to take place.

How does this bring new light to Pentecostal theology? To begin, it is a challenge to systematic approaches to the Spirit. This charismatic creational theology effectively makes lines of delineation more challenging in how we understand the relationship between the Spirit and creation. This does not go without saying that there should (and must) remain a fine distinction between the Spirit's role in humans and in nonhuman creation. For the presence of such a difference and delineation should not be questioned. Humans have a special assignment in the created order - by the power of the Spirit proclaiming the freedom through the gospel Jesus came to pronounce. But the Spirit in nonhuman creation makes this delineation a bit more messy than we might have hoped, for nonhuman entities are imbued with the same Spirit as creation. Some have caricatured

\footnotetext{
${ }^{939}$ Yong points to the Brazilian church as an example of the Spirit coming down on people of all color. "God is no respecter of persons and the Holy Spirit is seen to be given to all persons regardless of the color of their skin." Ibid., 38.
} 
this relationship, often defining it in terms of vitalism, pantheism, or panentheism. ${ }^{940}$ These categories require such strict lines of delineation that oftentimes even a scholar cannot discern the difference. But a pneumatological theology of creation makes these categories antiquated. Similarly, it reminds us that these lines of delineation are found nowhere in the texts of the scripture. That is to say, the biblical witness portrays a more messy approach to the Spirit's life in creation than a systematic theology can handle. The biblical world is one where animals speak in the Spirit (asses), the Spirit is portrayed as a natural being (dove, wind, fire), and even God's enemies (Pharaoh) have God's breath. The theological problem with breath is its messiness. It is an uncontrollable breath that is indiscernible at times. Thus, the very visceral nature of God incarnate makes it easier to extrapolate a theology of Christ than does a pneumatology. But despite its quietness, the scriptures portray a creation imbued from the day before day one with a Spirit that hovers over creation (Gen. 1) and redeems it from such destruction (Gen. 8), ultimately bringing fulfillment (Acts 2). God is on, in, and above the creation. In the same way a baptized catechumen emerges from the water, so the earth soaks with the Spirit.

As well, a theology of the charismatic creation could greatly reduce the gaping divide between oppressive humanity and oppressed creation. Ecofeminist approaches, such as that exemplified in Sallie McFague, have attempted to undercut the dualism between God and his created world. The creative attempt of McFague suggests the motif of the "Body of God" as a way to envision the relationship between God, God's creatures, and creaturely relationship. Similarly, our ecopneumatologists have shown that

\footnotetext{
${ }^{940}$ As does Travis Ables, "A Ladder Leading toward God: Pneumatology and the Environmental Crisis" in Conference of Society for Pentecostal Studies (Raleigh, NC: 2008), 5, (unpublished article).
} 
one of the reasons behind any oppressive force goes to the idea that "we" are different or "above" the nonhuman created order leading to a sort of creational slavery. But the charismatic creation — where Spirit enlivens humans and nonhumans alike — transcends the "mass mind" that imagines humanity as independent of the remainder of creation; but rather by the same Spirit humans are an essential part of the creation because both creation and believer's are baptized in the same Spirit. ${ }^{941}$ In fact, it is a central role of Acts 2 to offer a fulfillment of Joel 2 is the ongoing work of reconciling once relegated parties from one another. This same Acts 2 paradigm can generate a gender reconciliation where "both sons and daughters would prophesy" (Acts 2:17-18). If the ecofeminists believe the oppression of woman and land go hand in hand, then a Pentecostal approach found in the earliest Seymour model offers such a potential. For women in the Pentecostal movement are (or should be) given more prominence by this pneumatological outpouring. This should make ecofeminists proud as both women and creation are given new voice in a Pentecostal approach.

An ecofeminist critique of theological language is that it perpetuates violence against women and creation. But a Pentecostal charismatic pneumatology speaks to the freedom of both. Pentecostals already practice a rich ecclesiology based on the Spirit's descent appropriated in Acts 2 and given a foundation in the OT prophetic tradition. It is a tradition where women such as Aimee Semple McPherson can be front-page evangelists, the lame are seen as prophets, and a child of a black slave such as William

\footnotetext{
${ }^{941}$ Regarding this “mass mind," I allude to Carl Jung's classic Carl Jung, Undiscovered Self (Boston: Little Brown, 1958). Within, Jung contends that modern individualism is the result of the human person being subsumed into the cult of the corporate ultimately leading to a homogeneous existence.
} 
Seymour can be the "nominal leader" and apostle of a new movement. ${ }^{942}$ All part of a movement where, in 1906, as Hollenweger said, "white professors and black laundry women were equals!' ${ }^{943}$ Pentecostalism makes room for socio-economically nominal people to do profound ministry and lines of separation are broken down.

Pentecostal theology offers a model of the upside down kingdom where all persons are mutual, or as Mittelstadt and Hittenberger have called the "mutuality of body ministry." ${ }^{.944}$ Although this is not always practiced, as they contend that, "Pentecostal ministry often focuses on the strong and sensational body parts to the neglect of the weak and necessary sustaining parts of the body." ${ }^{945}$ But this is not a truly Pentecostal understanding of the Spirit. All believers under Pentecost are rightly to be understood in their egalitarian roles seen in Joel 2, and all Spirit-filled believers are prophets of the living God. This ecclesiological image has an important ecological implication. The charismatic gifting provided through the Spirit to the church is a beautiful reminder of the diversity the church can and should exude. It is this diversity which allows the church to be one of unity. I would contend that a more robust Pentecostal ecopneumatology would push this understanding of the church to the greater cosmic community, which should be understood both in terms of the church and the broader Oikomene, the entire known world which includes creation. That is, in the same way God breathes gifts into the church to edify the church, God gives gifts to humanity for the benefit of the entire creation. These ecocharismatic gifts are those humans alone retain. For beetles or pine

\footnotetext{
942 I borrow the phrase "nominal leader" from Larry Christenson referring to the egalitarian nature of the Azusa Street revival. Christenson, "Pentecostalism's Forgotten Forerunner," 29.

${ }^{943}$ Hollenweger, "Pentecostals and the Charismatic Movement," 551.

${ }^{944}$ Hittenberger and Mittelstadt, 142.

${ }^{945}$ Ibid.
} 
trees will never be to blame for nuclear waste. Nor can they solve a Western addiction to oil. Only humans have the ability to do this. Humans have the charismatic gift and ability to both steward and destroy creation. Similarly, a Pentecostal charismatic theology of creation is a critique of the modern "autonomous" self we have examined. Humans, in that setting, rely on the creational gifts God has bestowed upon them. Humanity relies on the gifts of air, food, water, and warmth from the sun to live. In the same way that Paul spoke of the body needing every part, Pentecostals can contribute to ecotheology a sense in which all of creation can be understood as a charismatic community in the same way Pentecostalism reemphasized gifts in the church. In this sense, the destruction of the earth can be understood in terms of the humanity forgetting that it is God-given gifting to care for and love creation, treating an essential part of the body as lesser.

This interconnected creation is an image that can and should shape the church's understanding of itself as an interconnected entity in reliance on the other parts to be sustained. ${ }^{946}$ For surely it offers Christians a beautiful model of interconnected and empowered ecclesial life based on shared mutuality as empowered by the Holy Spirit. That is, as creation lives in harmony, so should the church. But even further, Pentecostals offer ecotheology a beautiful model of ecclesial charismata with a rich history of seeing the prophethood of all believers. In a sense, Pentecostals can and should begin to speak of the "prophethood of all creation," understanding Joel 2 to include God's inner workings not just in "sons and daughters," but in the "billowing smoke" and the "blood red" sun. God's Spirit has truly been poured out everywhere and can communicate God's attributes

\footnotetext{
946 I am reminded here of George MacDonald's notion of the divine life, including that of the life of the church, as being "the divine organism." In George MacDonald, Creation in Christ (Wheaton: H. Shaw Publishers, 1976), 22.
} 
and purposes to the world. Again, the scriptures portray a story where animals speak, a serpent is used by Satan, and a donkey is used by God. These images are clearly part of the biblical story. Enmity between the two was substantiated in the first three chapters of the biblical narrative where the evil one (portrayed as a snake) deceives humanity into disobeying God. Yet one of the notes included in the extended ending of Mark's gospel comments that those who are filled with the Spirit will pick up snakes and not be harmed. This Spirit-filled paradigm therefore becomes the reversal of the enmity of Genesis 3. Because of the Spirit, harmony is once again possible.

Would this Pentecostal ecopneumatology have an ecumenical bent? Broadly, Pentecostals are not only in fellowship and dialogue with Evangelicals and RCs, but are even talking to more liberal Pietistic folk in the words of William Faupel. ${ }^{947}$ Matthias Wenk has rightfully illustrated the potential transformative value of pneumatology as it has been in Western Europe. ${ }^{948}$ Pointing to manifestations of the Spirit's sociological implications within Pentecostalism in and around the Azusa Street revival was much more powerful than earlier understood with outspreading work in Korea, South Africa, and beyond. He writes, "[W]hen it comes to questions...concern for the environment, Pentecostals in Western Europe are mostly speechless, and only a few will perceive an explicit relation between a pneumatological spirituality and these social/economic problems of our time." ${ }^{949}$ But he continues, in terms of socioeconomic, racial, ecclesial, and communal systemic issues, pneumatology has been deeply transformative. Wenk

\footnotetext{
947 Faupel, "Whither Pentecostalism."

948 Matthias Wenk, "The Holy Spirit as Transforming Power within a Society: Pneumatological Spirituality and Its Political/Social Relevance for Western Europe," JPT 11.1 (2002), 130-142.

949 Ibid., 131.
} 
rightly observes a problem: Pentecostal pneumatology has had a selective usage in particular parts of the church. Perhaps we could imagine ecological care as a form of ecumenism. Clearly, the Pentecostal movements have had both an "ecumenical and exclusivist" bent, and in many ways these have harmed Pentecostal theology. ${ }^{950}$ Many things have hampered this.

Gerald Sheppard's work has shown that the Pentecostal acceptance of dispensationalism have caused them to unintentionally mishandle and ultimately harm the truly distinctive Pentecostal theological tradition on a number of levels. ${ }^{951}$ This is perhaps no more the case than on an ecumenical level. But it must be understood that ecumenical work of bridging gaps in the body of Christ, and ecological work of bridging the gaps between humanity and nonhuman creation, are linked tasks. Both ecology and ecumenism seek to bridge broken relationships. And ultimately, at its ecumenical core, I would agree with Matt Tallman that Pentecostals are inherently ecologists; but they don't even know it! ${ }^{952}$ Based on the Spirit of God, we agree with Michael Welker and Jürgen Moltmann: "All things are called into being out of God's living breath, and that breath 'holds them together' in a community of creation which furthers life. If they cut themselves off from that community, they lose the living Spirit. If they destroy the community they destroy themselves.... The Spirit of life means especially the connections and cohesions of everything created....All things are mutually dependent; they live with each other and for each other, and often enough symbiotically within each other. Life is

\footnotetext{
950 On these "ecumenical and exclusivist tendencies," see Christenson, "Pentecostalism's Forgotten Forerunner," 31-32.

951 Gerald Sheppard, "Pentecostalism and the Hermeneutics and Dispensationalism: The Anatomy of an Uneasy Relationshiop," PNEUMA 6.2 (1984), 5-34.

952 Mel Robeck famously commented, "We Pentecostals are ecumenists, we just don't know it!" Robeck, "Taking Stock of Pentecostalism," 39.
} 
community, and community is the communication of life. ${ }^{953}$ A charismatic theology of creation seeks to heal broken relationships between humans and between human/nonhuman creation.

In terms of this ecumenical dialogue, we may see fruitful conversation between Pentecostals and Orthodoxy based on this charismatic creation. Pentecostal and Eastern theologies often tend towards a more similar mystical pneumatology, as Edmund Rybarczyk has shown in his Beyond Salvation ${ }^{954}$-although the progeny of both has come to a vastly different resting place. Hollenweger has illustrated the many ongoing struggles between Pentecostal theology and Eastern/Orthodox theologies. But perhaps a charismatic theology of creation could bring a more open willingness to crack the doors of dialogue. With these mystical similarities, a Pentecostal/Orthodox conversation on the Spirit's role in creation might perhaps be fruitful for both partners. Simon Chan's comment on the "charismatic dimension" of life "that is open to surprises from God" sounds very much as though he could be talking either about Pentecostal or Orthodox theology. ${ }^{955}$ The Orthodox have always had a visceral love for God's Spirit. Therein God's Spirit is a sort of incense wafting through the universe. Historically speaking, Pentecostals might be humbled to realize they largely owe their theological foundation of the Trinity to the Cappadocian fathers who would not allow the Spirit to lose its place in early Eastern theology. While there are similarities between the two, the outcomes of both will tend to be vastly different. But I will suggest that a Pentecostal theology of

\footnotetext{
${ }^{953}$ Moltmann, The Source of Life, 24.

954 Rybarczyk, Beyond Salvation.

${ }^{955}$ Chan, Spiritual Theology, 9.
} 
creation will open doors of conversation with Orthodoxy based on this mystical theology of God's Spirit. This will have the potential to lead to other areas of fruitful dialogue.

To be able to apply this charismatic creational theology appropriately, Mark Wallace's portrayal of the Spirit continues to be important. He reminds us that the language of the Spirit is subtle in scripture. The Spirit is not communicated in sacerdotal, religious, dogmatic language. It is in a simple yet straightforward word pictures that the Spirit's story is told. These Spirit-images of wind, of fire, of breath, and of a dove are telling on a theological level. Ultimately, he points out that God's Spirit can only be referred to in its biblical language in reference to something else. ${ }^{956}$ This is to say that conversation of the Spirit as other entities (e.g. dove, wind, water) implies a relationship to such things. Yes, these things are reminders and are not the Spirit herself, but the Spirit cannot be spoken of outside the context of such living, organic metaphors. With the proliferation of the extinction of many species, perhaps one species being lost an hour, ${ }^{957}$ would the possibility ever emerge where we had to reinvent a metaphor for the Spirit? What if all doves went extinct? What if no fresh running water was left on earth? The Spirit as dove would make little to no sense to someone reading the Bible if they were no longer present. In order to do theology on the terms of the Bible, we are unalterably required to do it in the arena of the world where we might see entities like doves, water, and wind. Pneumatology requires one to have been in the outdoor world to have seen

\footnotetext{
${ }^{956}$ I am reminded of William McClendon's overarching theme of "this is that" in his three-part systematic theology. That is "this," what we see now, "is that," what we remember and read about in the biblical text. James McClendon, Systematic Theology: Ethics, vol. 1 (Nashville: Abingdon, 2002); James McClendon, Systematic Theology: Doctrine, vol. 2 (Nashville: Abingdon, 1994); James McClendon, Systematic Theology: Witness, vol. 3 (Nashville: Abingdon, 2000).

${ }^{957}$ Lorna Green, Earth Age: A New Vision of God, the Human, and the Earth (New York: Paulist, 1994), 17.
} 
these sorts of things. Theology in the Christian sense is entirely dependent on a world of wonder in order for it to make sense to the human community. Thomas Berry reflects on this, and it is for this reason he suggests when we kill off another species, "we silence a divine voice forever." ${ }^{958}$ Creation, with all of its kinematic/animate parts, is a living sacrament of God's grace. Yet, humanity's wanton willingness to destroy such sacraments, to trash such metaphors, to trade quid pro quo the well-being of the signs of God's grace living and alive in the world is a sign of the breakdown of a theological heritage. As Wallace says, "In the same way the bread and wine are God, so is creation." 959

Finally, to envision the Spirit interconnecting all of God's creatures is to travel back to the garden and revisit the story of the city called Eden ("delight"). In Delight, six days were enough time for God to create what he had for eternity noetically known in his mind and heart. The original creatures were not malevolent to one other. They lived together and no fear existed between them. The head creature, Adam, named the other creatures; not as a postmodern power-play but as an act of responsibility, love, and authority. They lived in blessing because of the gifts they were to each other. Being a charism to one another, the garden was incomplete without humanity, the animals, the plants, the sun, and its God. To "imagine the world as the scripture imagines it," in the words of Timothy Luke Johnson, is to put the beauty of God's omniscient Spirit back into the garden where it was. ${ }^{960}$ The creation was a charism to humanity. It was a gift. Yet

\footnotetext{
958 Berry, The Dream of the Earth, 46.

959 Wallace, "The Wild Bird Who Heals."

960 This is borrowed from the title of Luke Timothy Johnson, "Imagining the World Scripture Imagines," MT 14.2 (1998), 165-180.
} 
humanity was as well a charism to the rest of creation. No other animal was commanded to "tend the garden" as was humanity. This was not the tree's responsibility, or the moons, or the butterflies. Nor was sin their fault. It was humanity's. Sin entering at the garden, in this sense, truly was a "crisis in culture." ${ }^{.961}$ Their gift of responsibility was to care for the garden and make it fruitful and keep it delightful. To help creation then, today, is to be filled with God's Spirit and continue the assignment left to Adam.

William Brown suggests a powerful word of caution in this regard. He proposes a post-White response of Christian theology will miss the point if it seeks to "heal creation" yet is unwilling to "heal the community." 962 That is to say, humans cannot heal all of creation without being healed themselves because it is still creation - a part of the garden. Brown's daunting task in Ethos of the Cosmos seeks to reconnect again, as it powerfully existed in the earliest cultures that imagined the cosmos, a direct link between the community that imagines and the community of creation. And if our imagination does not put ourselves in the garden, our efforts to fix it will be as a contractor from the outside, not a coworker on the inside. A charismatic community of creation respects the need to be the garden where God is king and humans are helpers. Perhaps L.S. Mudge was right when he wrote, "When we ask how our world takes shape, we are at the same time asking how the self takes shape." ${ }^{\prime 93}$

\footnotetext{
${ }^{961}$ Brown, The Ethos of the Cosmos, 25-27. Brown does not minimize the ecological crisis; rather he situates it in the larger context of the breakdown of human community. Therefore, the ecological crisis is a direct extension of a community in crisis.

962 Ibid., 3.

${ }^{963}$ L.S. Mudge, "Paul Ricoeur on Biblical Interpretation," in Essays on Biblical Interpretation, ed. Paul Ricoeur (Philadelphia: Fortress, 1980), 10.
} 


\subsection{The Holistic Spirit of Creation}

Now that we have looked at the Spirit baptized creation and the charismatic community of creation, we turn to the holistic Spirit of creation. As we have discovered, the biblical tradition portrays God's Spirit as it takes on flesh, fire, and form. Likewise, the Spirit falls on Jesus and his church. Now we are going to sketch another element of Pentecostal ecotheology: the holistic Spirit of creation. To begin, I would like to illustrate how the Spirit embodies creation, Jesus, and his church throughout the biblical narrative. Then I will construct a reflecting Pentecostal theology.

In the tradition of scripture, humans are dirt which are given breath. In this narrative, humans alone are portrayed as receiving a special anointing of breath (rûach) that other elements of creation do not receive. As a central feature of the larger creation narrative, humans are created out of the earth on the sixth day. The following day, Sabbath, is a commanded day of rest for creation and God. As we move towards the NT, creation is increasingly portrayed more as a Trinitarian event. In the beginning the Father creates the universe and all that exists bringing it to its created form (Ps. 19:1; 1 Cor. 7:6; Acts 17:28; Rev. 4:11). Christologically speaking, it is the Son who keeps it all together (John 1:3, 14; Col. 1:16; John 5:26). And finally, on a pneumatological front, it is the Spirit who continues giving creation vivifying life (Gen. 1:2, 6:17, 7:22; Ps. 104:30; Job 26:13). In sum total, the creation story is a story mediated through the stories of the Trinity; a story which must include the centrality of each of the members of the Trinity. Scripture unveils a Spirit that embodies all of creation giving it the breath of life (Gen. 2:7). Life depends on this breath, for when God takes away this breath, life ends. The 
psalmist reflects, "When you take away their breath, they die and return to the dust. When you send your Spirit, they are created, and you renew the face of the earth" (Ps. 104:4, 27-30).

Humans are not the only creational agents dependent on this Spirit for life. The entire gamut of the animal and human kingdoms intrinsically have a life dependent on the Spirit. This Spirit is the wind of life. Eduard Schweitzer writes, "The experience of the Spirit of God by the devout in the Old Testament is of something as real as the stormy wind rattling at their cottages and bending the trees, as real too as the breath of life that pervades them through and through and gives them life." ${ }^{964}$ We see this dynamic reality throughout the account of the Bible. Moses's experience had led Elijah to expect a particular revelation by God's Spirit to be that of a strong wind, earthquake, or fire. However, in Elijah's case God spoke in less than remarkable fashion, in "sheer silence" (1 Kings 19:11-12). The fleshiness of the Spirit is illustrated in Joel, where the Spirit of the last days will come with "blood, fire, and columns of smoke" (Joel 2:28-30). God's presence in his Spirit is powerful and wrathful. Lloyd Neve has shown us, especially in Isaiah, that God's Spirit is to be connected with God's wrath and his righteous judgment. ${ }^{965}$ Interestingly, in the NT, evil can be embodied with creation. We see that in the gospel of Mark where a herd of pigs are possessed with a legion of demons after Jesus casts them out (Mark 5:1-13). The Spirit and the spirits can embody physical entities.

\footnotetext{
${ }^{964}$ Schweizer, "On Distinguishing between Spirits," 406.

${ }^{965}$ Lloyd Neve, Spirit of God in the Old Testament (Minneapolis: Augsburg, 1972), 45-51.
} 
Jesus is likewise filled with the Spirit as the expected coming Messiah. He is conceived by the Spirit in the womb and is portrayed as the anointed anointer in the gospel accounts (Matt. 1:18-20). This Spirit, initiated in dove form, inspires the prophetic ministry of Jesus (Matt. 12:18) and gives him power to drive out evil forces (Matt. 12:28) and preach the Kingdom of God. Ultimately, we discover that the same Spirit who embodies Jesus will eventually anoint his disciples with the Spirit at Pentecost. Jesus's Spirit-anointing takes place at his baptism on the river Jordan where a dove descends on him as the representation of the Spirit. Aside from being a sign of the anointing of his ministry, some have suggested there are cosmological implications to this depiction of the Spirit as a dove. Birds would be seen as an intermediary with the heavens as they would go up to heaven and come down again. Similarly, birds have often played a role as an image of a deity in the Ancient Near East. Kirsteen Kim comments, "Birds make the air currents visible, and the hovering of the Spirit over the waters at creation implies a bird (Gen. 1:2)." ${ }^{966}$ We observe that it was a dove which brought good news of redeemed creation to the ark; similarly the Spirit proclaims Jesus to a broken world $9{ }^{967}$ Kilian McDonnell has suggested this dove gives a cosmic element to the Spirit. ${ }^{968}$ Holl continues, "The Holy Spirit is portrayed most often in animal form, in the shape of a dove, which places him beyond any human resemblance, in contrast to the Father and the Son and their familiar facial features. ${ }^{" 969}$ As does Jesus, the disciples will embody the Spirit of God. The Spirit takes on flesh, body, and personhood. It is the holistic Spirit.

\footnotetext{
966 Kim, The Holy spirit in the World, 12.

${ }^{967}$ McDonnell, The Baptism of Jesus in the Jordan.

968 Ibid.

${ }^{969}$ Holl, The Left Hand of God, $\mathrm{x}$.
} 
Jesus's disciples are portrayed as new humans who breathe God's Spirit poured out by Christ at the cross. Jesus intentionally furthers this idea of a "breathing creation" to the spiritual life his disciples would perpetuate when he speaks to them at the cross, "receive the Holy Spirit," exuding obvious undertones to the creation narrative (John 20:22). Just as God created Jesus's disciples, God's Spirit gives them new life as an essential element of discipleship. Truly, to participate in discipleship is to become a new creation to be breathed into once again as in the beginning. This idea of the "breath of life," connected to the dynamic infilling of the Holy Spirit, is seen at other points in the NT (Luke 8:55; Acts 17:25; Rev. 11:1; 13:15). ${ }^{970}$ Some, such as Mark's gospel, seem to have a more dualistic sense such as when Jesus commented that "the Spirit is indeed willing, but the flesh is weak" (Mark 14:38). Similarly, other references are quick to point out that the opposite of flesh is God (1 Cor. 1:26; 2 Cor. 1:12; 10:4; 11:17ff; see Rom. 9:8; Gal. 4:23).

And finally, the Pauline literature portrays a Spirit that embodies the human personhood in dynamic ways (1 Cor. 3:16-17; Gal. 5:22-23). It is Paul himself who suggests the human personhood consists, like the Trinity, of body, soul, and spirit (1 Cor. 16:18; 2 Cor. 7:1; 1 Thess. 5:23). The holistic Spirit of the church continues with Paul's theology of the new temple. With the emergence of the Christian tradition, these new Christian communities reinterpreted the meaning of the temple of God as being the Christian community. In Hebrew cosmology, the temple was considered the closest location on earth to heaven and a direct reflection of heaven. This, and its geographic locale, is why journeyers are always going "up to heaven" (2 Sam. 19:34; 1 Kings 12:28;

${ }^{970}$ Edwards, Breath of Life. 
Ezra 1:3). It is at the temple where God dwells with the people by his glory (shekina) in the holy of holies (Ps. 26:8). This is often a synonym of shekina ("glory"), from the root of shekn ("to dwell"), referring to God resting with his people in the temple and tabernacle. This, more than rûach, became the representation of the Spirit in the intertestimental period. As we see in Daniel, Shekina and Spirit are synonyms (Dan. 5:20). Paul, the apostle, later expands this theme ecclesiologically. In the earliest Christian communities, Paul taught that the body was the temple — our physical entityand that through the body is the believer's spiritual act of worship (1 Cor. 3:16-17; 2 Cor. 6:16). Eventually, Paul would contend that the church itself was a "holy temple in the Lord" (Eph. 2:21). And it is now that the believer and church manifest God's glory (2 Cor. 4:17).

So what might a theology of the holistic Spirit do for Pentecostal ecotheology? As we have seen, in the scriptural narrative, there is an intimate relationship between the Spirit and created beings. We have argued that the Spirit is embodied in creation. That is, the Spirit often takes on flesh. Building on both his earlier work on Trinitarian sexual theology and subsequent pneumatology, Eugene Rogers's sexual/liturgical body theology presents a thoughtful assist in understanding this holistic pneumatological body theology in the framework of a Trinitarian pneumatological spirituality in conversation with nonWestern sources. ${ }^{971}$ Although entirely forgetful of non-Western Pentecostalism and Charismatic movements in the South, Rogers rightly attempts a pneumatology not entirely informed by the West and describes a Spirit that fully incarnates the physical realm. Rogers speaks of a (para)physically Spirit empowerment coming from the life of

\footnotetext{
${ }^{971}$ Eugene Rogers, Sexuality and the Christian Body (Oxford: Blackwell, 1999); Rogers, After the Spirit.
} 
the Son. Rogers writes, "In the New Testament, the Spirit leads, follows, or accompanies the Son into the most intimate places: not, instructively, in the his 'mind' or 'heart,' but into much messier places, paradigms of the physical: the womb, the wilderness, the garden, the grace." 972 Here, the Spirit befriends matter and sanctifies all it touches from believer, to anointing oil, to churches. ${ }^{973}$ In the construct of Rogers's paradigm, we come face to face with a sort of deified or theosised creation welcomed into the divine Trinity by the embrace of the Spirit.

As Pentecostal theology has often been intertwined with Western philosophy, as Hollenweger argued, this more holistic pneumatological approach gives a more "spiritcentered" understanding to creation, Christian worship, and living in general. ${ }^{974}$ But nonWestern Pentecostalism, especially in the South, offers an important corrective to dualistic Western Pentecostalism which often forgets this messy relationship between the Spirit and matter. While this is more in line with Eastern understandings of nature, it is a much-needed correction to the atomization of creation so prevalent in Baconian utilitarianism pregnant in much of Western thought. How much more is this true in Pentecostal understandings of healing which will tend to focus on humanity's physical, mental, emotional, and spiritual healing?

In this context of the (para)physically present Spirit, healing can take place. This is on a number of levels: healing of the physical creation, healing of the interdynamic relationships of creation, and healing of the human psyche in its view of earth. Volf's

\footnotetext{
972 Rogers, After the Spirit, 54, (italics mine).

973 Ibid., 55. Rogers writes, "Since it is the Spirit whom Christians call down to sanctify people and things: deacons, priests, believers, water, wine, oil, incense, churches, houses, and anything that can be blessed...in many and various ways the matter of the world becomes the element of a sacrament."

974 Hollenweger, "All Creatures Great and Small."
} 
connection between liberation and Pentecostal theologies, based on healing, rightly showed that within Pentecostal theology there is an inherent belief and practice of sociological, political, physical, and bodily healing based on pneumatology. Developing this even further, Volf's important soteriological masterpiece of Exclusion and Embrace reminds us that reconciliation within the Kingdom of God seeks to heal both victims (nonhuman creation) and the victimizer (humanity) who have perpetrated them. ${ }^{975}$ Thus the holistic Spirit, which embodies humans and nonhumans, seeks to bring healing not just to the victimized but the victimizer. The victim of creation is therefore given a pneumatological format for new affinity with the perpetrator, humanity. Here, ecofeminist discourse, domestic abuse, pneumatology, and social justice coalesce to reimagine the ecological crisis as a victim/victimizer relationship whereby humanity is guilty of domestic abuse of creation. How fascinating that could be for ecotheology, an understanding of the ecological crisis in terms of domestic violence. In order for this to take place, a greater discussion on the dualism in much of Pentecostalism will be necessary. Nevertheless, I would contend, there is ingrained in much PC theology a dualism of gospel: the gospel of salvation for soul and soil. That is to say, Pentecostals have soteriologically viewed salvation almost entirely in terms of the far and off. As we have seen, this no doubt arose from a number of sources such as eschatology, its upbringing, and its revivalist tendencies. And this emphasis is not a negative thing — quite the opposite. Pentecostals have brought to the broader global ecumenical community a much-needed revival in preaching, evangelism, and power-ministry. But Pentecostals,

\footnotetext{
${ }^{975}$ For both of Volf's works on the topic, see Volf, Exclusion and Embrace; Miroslav Volf, "The Final Reconciliation: Reflections on a Social Dimension of the Eschatological Transition," MT 60.1 (2000), 91113. To some degree as well, see his Trinitarian ecclesiology. Miroslav Volf, After Our Likeness: The Church as the Image of the Trinity (Grand Rapids: Eerdmans, 1998).
} 
with their view of the immanent Spirit, have forgotten how necessary it is to be healed of oppressive forms of living towards creation.

This holistic Spirit greatly helps us conceptualize both the role of the individual in the church and the role of every partner in creation as part of the broader cosmological picture. The holistic Spirit therefore helps us see again the church and creation as holistic bodies that are interdependent and interdynamic. Neither creation nor church are simply a collection of different parts. Rather, they are parts that are reliant and dependent on one another. A greater ecclesiological understanding of the charismata emphasized by PC spirituality was the central basis for the earliest Pentecostal ecotheology writing in Jean Jacque-Suurmond. He argued that Pauline ecclesiology of the body of Christ is a model for our understanding of creation, and likewise, ecology/creation should form and inform our ecclesiological understanding of the church. The church is as dependent on its gifted parts and its head Christ in the same way the creation is interdependent on its gifted parts and its Creator God. For Pentecostals, the body can be a holy thing. As theologian Daniel Albrecht has so eloquently observed, Pentecostals worship God with their whole bodies. ${ }^{976}$ They raise their hands, they dance, and they sing wildly. This is evidenced by PC church gatherings with worshippers on their knees, raising their hands, an often speaking in tongues. This whole body experience establishes an aptitude for spiritually understanding God in a holistic sense. For Pentecostals, the body is a medium of worship. The earliest ethos of Pentecostals emphasized caring for one's body (no smoking, no premarital sex) as an act of worship because the body is the temple of the Lord. The body can be good. This oddly juxtaposes much of Western religion which continues to see the

${ }^{976}$ Albrecht, Rites in the Spirit. 
body as evil and spirit as good. As the entire human body, soul, and spirit encounters God in worship, all of God's creation (or God's body to use McFague's wording) is created to worship God. An ecopneumatological understanding of the creation would help to put creation into context for Pentecostals, the setting being the life of the Spirit. Sadly, this holism has been extended dualistically in church services but not the broader context of life.

Body and soul are both created good in the creation account of scripture. Clearly, early Pentecostal reflection tended to exude a very pessimistic perspective towards the system of this world. Participating in such activities as going to the fair, chewing gum, drinking alcohol, and buying insurance out of lack of faith in God were viewed by many as sinful. ${ }^{977}$ This was coupled by a view that the world was the stage of Spirit-inspired ministry. This parallels much of the Free Church's understanding of the presence of Christ. For a view of the Spirit of the whole takes the "unmediated presence of Christ to each believer through the Spirit" and grows it to the greater creation. ${ }^{978}$ As we have seen from an examination of recent pneumatological swings in Pentecostalism, Pentecostals tend to differentiate between the soteriological and empowerment motifs of the Spirit both in scripture and in experience. This line is often seen in Pentecostal discussions with non-Pentecostals such as Dunn and Bruner. Often Paul and Luke are pitted up against each other: Paul, the soteriological pneumatologist, concerned with the former, and Luke the historian/theologian, the latter. But a Pentecostal ecopneumatology would help to quiet that bifurcation. And a holistic understanding of the Spirit within creation will lead

\footnotetext{
${ }^{977}$ Synan, The Holiness-Pentecostal Tradition, 18.

${ }^{978}$ Quoted in Yong, The Spirit Poured out on All Flesh, 126.
} 
to a blurred line between the two. That is, human salvation and creation restoration become similar effort because the Spirit is already up to both. ${ }^{979}$ In other words, ecopneumatology, if viewed holistically, sees the Spirit in every element of healing, wherever it may be. It conceptualizes the Spirit of God not only in creation but also in restoration. In this context, the Spirit filled church participates in this healing. That is, the very ones that are created have Spirit-empowered witness to make efforts to keep the creation from destruction. To not care for creation, therefore, is in a sense a way to "grieve the Holy Spirit" (Eph. 4:3).

Worship in the Spirit becomes the force that draws Spirit-embodied believers together in praise. When we worship together in the Spirit's presence, there is continually a sense that the Spirit is in some way reconciling human-human relationships. We confess, forgive, and heal broken relationships. How one views the Spirit in all entities will adjudicate one's relationship to all things. John Taylor reminded us of this relational imagination of the Holy Spirit as the Go-Between God who creates and restores all human relationships. ${ }^{980}$ But on a broader level, the Spirit is the interdynamic presence between all creatures: between humans, between creatures, and between humans and creatures. That is to say, the Spirit is the God between all creatures attempting to reconcile and bring together. This touches slightly on Andrew Gabriel's concept of the relationship of the Spirit to technology, and technologies effect on the larger natural scene. ${ }^{981}$ The Spirit is seen not as simply a force or entity, but a drawing force bringing

\footnotetext{
${ }^{979}$ Again, for a helpful summation of the "subsequence" theology in Pentecostalism, see the earlier chapters of Macchia, Baptized in the Spirit; Mittelstadt, Spirit and Suffering in Luke-Acts.

980 Taylor, The Go-between God.

${ }^{981}$ Gabriel, "Pneumatological Perspectives for a Theology of Nature."
} 
all creatures together, the "beckoning reality" as it were, that "so compels it (reality) to relate to others in a particular way. $" 982$ Humans must therefore return to relationality with creation by the laying on of hands. On a broader scale, the Holy Spirit is the God who goes between humans and nonhumans in the same way the Spirit brings together believers in worship. He is the God that beckons each in relationship towards one another. In that way the Spirit between us all is a "flame of love," 983 giving us love for animals, love for plants, love for stars, and love for the earth. Pentecostals are ready to admit this in terms of ecclesiological terms: between Spirit-filled believers. But can this not be understood as well in terms of Spirit-filled creatures?

What can be said regarding a theology of healing for creation? This motif of love for creation is central in Harold Hunter's original ecotheological sketch focusing on the “Healing of God’s sick Creation." ${ }^{984}$ For Hunter, earthen healing such as creation care and ecojustice can and should rightly fall under the rubric of spiritual healing, not simply physical healing. Clearly, for Pentecostals, healing is not an uncommon practice or belief; it is for many within the PC movement's spiritual praxis and a way of life. Yet I would contend there is a latent Pentecostal spirituality of an immediate understanding of healing. And this understanding is only half of the picture. This immediate form of healing is often understood as the "miraculous" sense of healing. This is seen in someone healed from cancer by prayer or someone healed from blindness by the laying on of hands. These are rightly considered miracles. But the larger construct of "miracleworker" or "miracle" has to do with that which is unexplainable, an important element of

\footnotetext{
982 Taylor, The Go-between God, 31.

983 I refer here to Pinnock, Flame of Love.

984 Hunter, "Pentecostal Healing for God's Sick Creation?."
} 
what "miracle" means. But I would contend that the category of "immediate healing" is too limiting, especially in regards to the salvation of creation. What will be necessary, therefore, for a PC theology of healing regarding the earth will be a more processoriented understanding of healing where laying of hands is equally as important. ${ }^{985}$ As we lovingly lay our hands on the soil, the tree, and the animal to care, healing is possible. And creation can, through God's Spirit, heal creation over years, decades, and generations.

\subsection{The Eschatological Spirit of Ecological Mission}

Finally, as a concluding element of our PC ecopneumatological establishment, I would like to suggest that Pentecostal ecotheology and practice has an eschatological dynamic. Without question, many before us have imagined the social power of the eschatological Spirit. Broadly, nevertheless, the earliest Pentecostals interpreted the eschatological nature of Christ's return as a call to preach the gospel to every nation. Yet, in the earliest Pentecostal movements, social justice and practice was "blurred" in the wave of eschatological fervor in favor of more evangelistic enterprises. ${ }^{986}$ Witness was interpreted largely in terms of evangelism. For this reason, Hendrikus Berkhof has noted that Pentecostalism offers a furthering of the Spirit for justification and sanctification to the

\footnotetext{
${ }^{985}$ Shane Clifton alludes to this in his article. He writes, "[T]he tendency of Pentecostals to thereby be oriented to 'the miraculous,' and away from 'the natural,' may be seen to have contributed to the failure to appropriate the various theologies of nature that have generally grounded ecotheological developments in ecumenical contexts." Clifton, "Preaching the 'Full Gospel' in the Context of the Global Environment Crises," 123.

${ }^{986}$ Kärkkäinen and Yong, eds., Toward a Pneumatological Theology, 181.
} 
"third element," empowerment for witness into the world. ${ }^{987}$ But could the coming of this eschatological Spirit perhaps have broader implications to areas of social justice, political change, and ecological repentance? In light of the ecological injustices of creation, I would here like to suggest that it can and does construct a Pentecostal theology of eschatological ecological mission.

The OT connects the coming of the Spirit with the age of the coming Messiah who would redeem Israel and the world from its many oppressive forces. A number of the Hebrew prophets, especially Isaiah, expectantly anticipated the coming day when Yahweh's glory would be disclosed upon all flesh and available to all of humanity (Isa. 40:5). Joel similarly prophetically discerns the Spirit's coming on "all flesh" in the context of these strong eschatological undertones (Isa. 47:3; 59:21; Joel 2:28-32; Ezek. 39:10). Isaiah points out that it is in this in-breaking Messianic age where peace (shalom) was possible, children would lay down with asps and adders (Isa. 11:8-9) in clear reversal of the original curse (Gen. 3:15). Referencing to the Year of Jubilee (Yobel), Isaiah imagines the proclamation of the Year of the Lord's favor in connection to a future anointed leader (Isa. 61:1-3). In the NT, Luke goes out of his way to connect Isaiah's eschatological expectancy with the person, work, and ministry of Jesus. In Luke's gospel narrative, Jesus reads from Isaiah's prophecy, envisioning himself as the bearer of the Spirit to bring justice to all (Luke 4:18-19). All eyes were "fixed" on Jesus from this moment on. Jesus's ministry was to be a purging fire that brings judgment on the world (Luke 12:29). This judgment would follow a new age.

${ }^{987}$ Berkhof, The Doctrine of the Holy Spirit, 90. 
Throughout the NT, Jesus and the Spirit he gives are envisioned as an eschatological sign of a coming new age (Matt. 12:28; Eph. 1:13-14; Heb. 6:5). It is in this context that the earliest Christian community interpreted Jesus's life, ministry, and death as the fulfillment of OT prophecy (Matt. 12:28; Eph. 1:13-14; Heb. 6:5), God's victory over the evil powers of this age (Mark 3:23-27; Luke 10:17-18; 11:19-20). The same Spirit that empowered Jesus empowers the believers at Pentecost in fulfillment of Joel's prophecy. Spirit baptism as exemplified in Acts 2 is an eschatological sign of the end-days, preparing God's people for acts of witness to usher in this new age. The falling Spirit like "tongues" on those in the upper room marks this. The eschatological nature of Spirit baptism through Jesus's death and resurrection, and ultimately on those in the upper room, is the cornerstone of Pentecostal spirituality, as pointed out by Lyle Dabney. ${ }^{988}$ Luke Timothy Johnson has likewise identified the eschatological nature of the gift of the Spirit at Pentecost. ${ }^{989}$

The Pentecostal movements have struggled to live up to the eschatological vision of its pioneers and visionaries which emphasized this Pentecostal theology. Perhaps it was for this reason, the unfulfilled vision of Pentecost, that it is often said that William Seymour "died of a broken heart." "990 The second generation Pentecostals watched as the quickly expanded movement's Seymour sought to initiate in Los Angeles, what in the early-twentieth century quickly became institutionalized as the power structures of denominationalism took the once potentially powerful movement of believers who were

\footnotetext{
988 Lyle Dabney, "Justification of the the Spirit," in Starting with the Spirit, eds. Gordon Preece and Stephen Pickard (London: SCM, 2001).

989 Luke Timothy Johnson, Gospel of Luke (Collegeville: Liturgical Press, 1991), 209.

990 Hollenweger, "Pentecostals and the Charismatic Movement," 551.
} 
all prophets, where race, power, and authority all played little to no role. These movements, in the setting of eschatological fervor, began as a community of Spiritempowered wanderers who sought for God's justice, the spread of the gospel, healing of the sick and the blind, and the raising of the dead. Pentecostals were a unique people for a unique time. They were deeply ecumenical, evangelistic, countercultural, culturally minded, and resistant to worldly powers. Hocken and Faupel's analysis theologically and historically demonstrates this important strain. ${ }^{991}$ William Faupel has even gone so far as to argue that the earliest Pentecostals did not see their implicit role in converting the world of pagans around them; rather, their main role was to speed up the parousia. ${ }^{992} \mathrm{He}$ later goes on to argue that the loss in soteriological zeal was replaced by what Faupel calls the "pneumatological center." 993 Thus, the largest stress lied not in converting the world to Christ but ecclesiological and personal holiness and sanctification for the return of Christ. This remained, for some time, free from the powers of fundamentalist legalism while continuing as a revivalist phenomenon. ${ }^{994}$

But modern-day Pentecostalism has moved away from many of these roots. Perhaps this is why a Spirit-Christology understanding of the ministry of Jesus is paramount in this ecological age. ${ }^{995}$ For Jesus is still the Spirit-empowered Messiah with

\footnotetext{
991 See both Faupel, The Everlasting Gospel; Hocken, "Baptized in Spirit—an Eschatological Concept."

992 Faupel, The Everlasting Gospel, 21.

993 Ibid., 79.

994 Such a perspective is laid out in Robby Waddell, "Revelation and the (New) Creation: A Prolegomenon on the Apocalypse, Science, and Creation," in The Spirit Renews the Face of the Earth, ed. Amos Yong (Eugene: Pickwick, 2009), 30-50 (35-36). Waddell cites articles in Apostolic Faith dealing with racial and social barriers of the earliest Pentecostals. As an aside, he notes that tongues, as a sign, were a part of God's larger eschatological purposes.

995 Again, see Menzies, Empowered for Witness; Menzies and Menzies, Spirit and Power; Stronstad, The Charismatic Theology of St. Luke; Stronstad, The Prophethood of All Believers. For a more strictly
} 
the power both to save the world and usher in the new Kingdom of God, anointing a generation of eschatological workers who prepare the world for his return. Jesus's echoing of the prophet Isaiah are as powerful today as they ever were: "The Spirit of the Lord is upon me, because he has anointed me to bring good news to the poor. He has sent me to proclaim release to the captives and recovery of sight to the blind, to let the oppressed go free, to proclaim the year of the Lord's favor" (Luke 4:18-19). The Spirit is still upon him and upon his followers. Jesus is still releasing the oppressed and breaking chains. He is a missional Christ calling his missional followers to break the bonds he came to destroy. While Macchia sought to show that one of the main reasons Pentecostal theology has slipped from Spirit baptism has been that of a shift towards eschatology, but we must reengage the notion that the two are inherently connected biblically, theologically, and practically. To be Spirit baptized is to be an eschatologically expectant being. And as we have discovered, eschatology can truly shift our social and ecological mindset, as evidenced by both Peter Althouse and Nazarene Truesdale. ${ }^{996}$ But the reality is that eschatological witness in the twenty-first century goes beyond simple door-to-door evangelism or helping people speak in tongues. In an ecological age such as this, ecological justice and ethics are part and parcel of the Spirit baptized life. It is an eschatological activity of ushering in God's Kingdom of justice and righteousness where all bonds are broken, all oppressions are ceased, and all chains are thrown off.

Protestant approach to Spirit Christology, see Jürgen Moltmann, The Way of Jesus Christ: Christology in Messianic Dimensions, trans., Margaret Kohl (New York: Harper SanFrancisco, 1990).

996 Peter Althouse, "In Appreciation of Jürgen Moltmann: A Discussion of His Transformational Eschatology," PNEUMA 28.1 (2006), 21-32; Albert Truesdale, "Last Things First: The Impact of Eschatology on Ecology," PSCF 46.2 (1994), 116-122. See also Douglas Moo, "Nature in the New Creation: New Testament Eschatology and the Environment," JETS 49.3 (2006), 449-488. 
The Spirit gives power to believers to stand up against injustice and unrighteousness in the same way as Jesus's Spirit-empowered role was deeply based on the justice of healing the blind, freeing the oppressed, and inaugurating God's justice in the world. This view of Spirit baptized empowerment now has the context to be extended to ecological issues. As we have observed, the earliest Pentecostals were a rag-tag group of nobodies with an unbelievably indeterminate amount of patience to fight the racial injustice of the time. They sought to destroy the barrier lines of black and white, women and men, slave and free. These were Spirit-filled believers who rightly saw their social role in the world as bringing the eschatological expectation to fruition-all because they were a group of Spirit-empowered people. Now, as illustrated in the charismatic approach to the social justice of Larry Christenson, Spirit baptism can be viewed paradigmatic of the socially just lifestyle. ${ }^{997}$ In this way, Christ brings freedom to live a new kind of life. But sadly, as evidenced by Murray Dempster's idea of the "social quietism" of Pentecostalism, many Pentecostals have equated the coming Christ with unjust and unsustainable living. Can this Pentecostal way of life be ecologically just? For Pentecostals would not actually believe that a righteous response to Christ's freedom is really oppression of creation with no regards to the created order. Now, in our current context, we must speak of an eschatologically-driven social justice where caring for creation is a Spirit-inspired task. Can Pentecostals continue to rightly prepare for the return of Christ with expectance, realizing that putting on some gloves and cleaning up the river is part of preparing room for the bridegroom of his church?

\footnotetext{
${ }^{997}$ Christenson, A Charismatic Approach to Social Action.
} 
Many ingrained aspects of PC theology will make this a challenge. First, premillenial eschatology, which has long played a central role in Pentecostal theology, must be reimagined for ecological purposes. Dwight Wilson writes, "[S]ince the end is near, [classical] Pentecostals are indifferent to social change and have rejected the reformist methods of the optimistic postmillennialists and have concentrated on 'snatching brands from the fires' and letting social reforms result from humankind being born again. ${ }^{.998}$ But the ecological situation demands more from Pentecostal eschatology than this. Many Pentecostals have long held that Christ would rapture his church before the millennial reign which is followed by an apocalyptic cataclysmic event (Rev. 20:1-6). This leads to Christ's reign on earth for one thousand years. Before this will take place, it is believed a seven-year tribulation, called the Great Tribulation, will bring destruction to earth. ${ }^{999}$ These tribulations are to be a sign that the rapture is soon coming. Many signs evidenced the coming parousia, as Faupel has shown. ${ }^{1000}$ Political, social, and ecological disasters will come with fires, earthquakes, and famines, which are all signs to Pentecostals that the world is nearly coming to an abrupt end. Sadly, in this eschatological paradigm, ecological catastrophe is viewed as a sign that we are on the right track to the fulfillment of all things. It is for this reason that Tony Campolo has commented that for some (even Pentecostals), this ecological holocaust is a kind of good news. ${ }^{1001}$

\footnotetext{
998 S.M. Burgess and M. van der Maas, eds., NIDPCM, 601-605 (605).

${ }^{999}$ Based on Matt. 24:21; Rev. 2:22, 7:14. See also Mark 13:19; Luke 21:23; Rev. 3:10.

${ }^{1000}$ Faupel, The Everlasting Gospel.

${ }^{1001}$ Campolo, How to Rescue Earth without Worshipping Nature.
} 
Another equally difficult challenge Pentecostal eschatological social justice will have to overcome is that of the "health and wealth gospel." Eschatological social justice rightly envisions resources as avenues to bring justice to the world. The Pentecostal connection of the gospel to financial health and wealth does so to the disparity of the creational health and wealth. It offers a theological paradigm for consumerism, greed, and unjust and unsustainable living, all in the name of the gospel. How does it communicate the gospel when more Pentecostals are focused on the "health and wealth" gospel of their bank accounts, yet fail to realize their unwillingness to care for the "health and wealth" of the earth? What kind of gospel is so acute it only concerns itself with human life? As I have said, premillenial theology is not to be defeated. Rather, premillenialism that empowers unjust living in light of the parousia or celebrates ecological devastation as the possibility of the coming Christ must be defeated. Premillenial eschatological living should rightly view the task at hand of preparing the world for Christ's return rather than destroying it to prepare it. Likewise, an ecological lifestyle is a form of the "health and wealth" gospel in that it brings to the table the idea that if we all live under the narrative of Christ, the "health" and "wealth" of all creation must be ascertained: not just humanity's.

With important exegetical work on John's Revelation, Robby Waddell brings two important elements to the table regarding these challenges. ${ }^{1002}$ First, he offers a critical yet faithful stance towards fundamentalist dispensationalism that is too often a Pentecostal staple. That is, Waddell offers a model via media between Pentecostal faithfulness to premillenialism and new and engaging eschatology with more promising

\footnotetext{
1002 Waddell, "Revelation and the (New) Creation."
} 
social dimensions. Secondly, Waddell provides a reinvigorated eschatology more in line with restorative elements of the Kingdom of God. His engagement with Moltmann and "already/not yet" Kingdom theology is a helpful corrective to eschatologies that too often write off present needs of the earth.

Pentecostals, in eschatological community, must understand that if Jesus was about freeing the oppressed, then so must his church. This is highlighed with their understanding that the Spirit filled church is the presence of Christ on earth. As we have seen, PC theology emphasizes Luke's account that connects the ministry of Jesus and the ongoing ministry of the Holy Spirit through the church in his two-part Luke-Acts account. This connection between Jesus's ministry and the Church's is, in Macchia's estimation, "without question." ${ }^{1003}$ In this way, the church is the second coming of Christ. They are the embodiment of Jesus on earth awaiting Christ's third coming. A major element of this Spirit-filled mission of Christ's church is empowerment of the renewal of love for creation. Pinnock argued that the pneumatological vision is that of the "flame of love." 1004 That is, creation is a love-imbued realm for the Spirit not only to help create (creatio ex nihilo) but continue in the creative process (creatio continua). Creativity, as a part of God's character through his Spirit, is a necessary part of human life and the larger creativity imbued in creation. To see two bear cubs play is to see the omnipresent Spirit inspire play. Creative mission, seeking and finding new ways to evangelize, that develops church and theology all within the confines of balance are Spirit-inspired activities built into the fabric of the cosmos. Love is therefore fleshed out in practicing ecological care.

\footnotetext{
1003 Macchia, "Pinnock's Pneumatology," 171.

1004 Pinnock, Flame of Love
} 
As it has been written, "Salvation is not an escape from creational life... it is the restoration of God's rule over creation.",1005

There is undoubtedly an important missional element to ecological equity and care. The hour has come for Pentecostals to come to grips with this. While preaching a "full gospel” message with a "half gospel” action may seem acceptable, Spirit-directed praxis and theory should, and must, include the wholeness of life. There remains a sort of dialectical approach to Pentecostal spirituality that seems to be missing, the endless dance of theory and praxis. Both are imperative and are left dancing alone if missing their partner. And in North American culture in particular, where mission is needed more than ever, this dialectical theory/praxis dance is essential. We must quickly understand that the "full gospel" message cannot be preached in power unless it is amplified by its practice in power. To put it more succinctly, our mission must "be authenticated by a ministry of social action that puts into practice what it preaches."1006

While historically, some have argued, American Pentecostals have been deemed "doers" rather than "reflective thinkers,"1007 a somewhat corrective balance has been welcomed by many — that is to say it has been welcomed by some and feared by others. ${ }^{1008}$ No doubt the entrance of PC studies into mainstream academia with PNEUMA in the 1970s and JPT in 1992 has done much to pave rigorous academic roadways for Pentecostals and non-Pentecostals alike to discuss theological discourse in a much more

\footnotetext{
1005 Craig Bartholomew and Michael Goheen, The Drama of Scripture: Finding Our Place in the Biblical Story (Grand Rapids: Baker Academic, 2004), 199, (italics mine).

1006 Arrington, "The Use of the Bible by Pentecostals," 129.

1007 Dempster, Klaus, and Petersen, Called \& Empowered, 3.

1008 The fragile relationship between Pentecostal and Evangelicals within the academy has been widely documented. For a good treatment of many of the reasons for this split, see Hofstadter, Anti-Intellectualism in American Life.
} 
open and constructive environment. With a resurgence, some would say a beginning, of discourse on theological, ethical, and philosophical topics (just to name a few), Pentecostals are slowly encountering the thinking and writing of many ecologies, ecotheologies, and ecopneumatologies. And once again, to quote William Dempster, "If this 'coming of age' is to have staying power, then social programs will need to find support from solid theological foundations." ${ }^{1009}$ No doubt the missionary sense of the church must continue to live in its three-fold element of social change: kerygmatic (the preaching and proclamation), community (the living fellowship of believers), and diakoniac (the service of the world). ${ }^{1010}$

With Sallie McFague's contribution of the Spirit's role as the one who empowers people for earth care, we can see the importance of the Spirit in empowering all believers for social care. But could the category of the prophethood of all believers be too limiting? That is, a view of the Spirit working through any source possible could envision a pneumatological understanding of the ecojustice movement in general. In this sense, the voice of the Lord in leading even nonbelievers to seek the restoration of the earth in their own understanding would make sense in this paradigm. NT Pentecostal scholar Robby Waddell exegetes John's theology of the ushering in of the new heaven and new earth found in the book of Revelation, an important theme for ecotheology which can radically change one's stance towards the earth. Waddell reminds us that John "does not say God is making new things but is making all things new." ${ }^{1011}$ Rightly critical of Pentecostal culture's addiction to "far-off" eschatology, he observes that most North American

\footnotetext{
1009 Dempster, Klaus, and Petersen, Called \& Empowered, 22.

1010 Cox, The Secular City, 108-129.

1011 Citing Rev. 21:5, see Waddell, "Revelation and the (New) Creation," 31.
} 
Pentecostals "talk about heaven, the conversation often begins with either a longing to see a loved one who has died, hope for a physical healing that seems overdue, or simply a desire to see Jesus. ${ }^{" 1012}$ Drawing on Moltmann, Waddell agrees, this conceptual model of heaven is detrimental to such endeavors as creation care. ${ }^{1013}$ This fundamentalist dispensationalism encourages a "passive resignation towards the present affairs of this world rather than a hopeful anticipation of a renewed and transformed creation." ${ }^{.1014}$ What is needed is a renewed social vision which can arise when Pentecostals grasp the "already/not yet" Kingdom as opposed to the apocalyptic one with which Pentecostalism has been married. ${ }^{1015}$ Social science examination of Pentecostalism, though few and far between, has been strengthened by the work of such scholars as David Martin and Margaret Poloma. While Martin points out that Pentecostals see "the world their parish," many are calling for Pentecostals to see "the earth their parish." What Martin calls "Pneumatic Lay empowerment" 1016 is essential to charismatic community life and action. The Spirit in the whole church, each individual, not institutional centered, but Spirit centered, is a church energized for social justice. Martin does point out the challenges of Pentecostal acceptance in the broader church catholic as well as its potential cultural and

1012 Ibid.

${ }^{1013}$ Waddell speaks here of the restitutio in integrum, or the "return to the beginning." Ibid., 44. Later, using Moltmann's phrasing, "In the End - the Beginning." For Moltmann's vision of a return to the beginning at the eschatological fulfillment, see his Jürgen Moltmann, In the End -- the Beginning: The Life of Hope, trans., Margaret Kohl (Minneapolis: Fortress, 2004).

1014 Waddell, "Revelation and the (New) Creation," 35.

1015 Ibid., 36. Waddell, earlier in his text, made the point that there are three traditional views of eschatology: the apocalyptic eschatology which emphasizes the coming destruction of creation, a realized eschatology which sees the Kingdom of God fully present in the words, life, and being of Jesus, and "already/not yet" or inaugurated eschatology. He argues throughout his text that Pentecostals have historically clung to the first of the three. See footnote at ibid., 32 .

${ }^{1016}$ Martin, Pentecostalism, 14. 
societal influence, the overall message seems to be clear. Pentecostals are making their mark. $^{1017}$

As Peter Wenz suggested in "Environmentalism and Human Oppression," there are striking connections between how humans treat creation and treated slaves. ${ }^{1018}$ The creation is here envisioned as a slave, while the Spirit brings freedom. The Spirit is therefore seen as bringing freedom to people to live lives bringing freedom to other slaves. "Where the Spirit of the Lord, there is freedom." (2 Cor. 3:17) It takes free people to free creation. It takes oppressed people to oppress it. In the same way Luke focuses on a Spirit-Christology, Acts on a Spirit Soteriology, the end times today need a Spirit Eschatology. That is, the Spirit's preparation for both the incoming presence of Christ and the return of his being to earth. This Spirit eschatology makes great space for a Spirit ecology, an understanding of creation in both pneumatological and eschatological terms. This eschatological feature is both realized and future. ${ }^{1019}$ This focus on eschatology must be carefully differentiated from what Dermawan Augustinus called "otherworldliness." ${ }^{1020}$ That is to say, a focus on heaven should never take us away from the social responsibilities of continuing to care for the earth. While many of the earliest theological convictions of the Pentecostal movement were of pacifist and peacemaking persuasion, there was often a classic anthropocentric sense to Pentecostal ethics. For instance, in one of the earliest pacifist texts published in a charismatic Spirit argued that

\footnotetext{
1017 Ibid.

1018 Peter Wenz, "Environmentalism and Human Oppression," in The Ecological Community, ed. Roger Gottlieb (New York: Routledge, 1997), 3-21.

${ }^{1019}$ Yong, The Spirit Poured out on All Flesh, 90.

${ }^{1020}$ Dermawan, "The Spirit in Creation and Environmental Stewardship," 210.
} 
all ethics, "as in all questions of right or wrong, everything comes finally to a point, and that point is life-human life."1021

Finally, Volf reminded us that Pentecostals tend to focus on the anihilatio mundi while liberation theologians the transformatio mundi. ${ }^{1022}$ But a Pentecostal ecopneumatology plays no favorites in terms of eschatology. That is, social justice and eschatology can never be mutually exclusive. Eschatology will always shape social justice and one's willingness to care for the created world will ultimately shape one's eschatology. To concern oneself with what God cares for on earth will largely prepare one for the coming. The Spirit, therefore, plays the middle ground of "from above" theology (Pentecostals) and "from below" theology (liberationists) because the Spirit is here and now pulling us towards the greater Kingdom Christ is establishing. The Spirit allows us and calls us to a tension of expectation and experience. This is where Peter Althouse's work will serve as a deeply important stepping stone for Pentecostal social justice in this new ecopneumatological development. As Althouse has established in his engagement with Pentecostal history and such theologians as Moltmann, Pentecostal theology must come to terms with a greater understanding of Kingdom theology and eschatology, especially through its conversations with those outside (Jürgen Moltmann, e.g.). ${ }^{1023}$ That is to say, Pentecostals are both coming to terms with an eschatology that has not yet been realized and an eschatology that must become more transformative in the present. Therefore, eschatological understanding is beginning to turn to a broader

\footnotetext{
1021 Arthur Booth-Clibborn, Blood against Blood (New York: Doran, 1914), (italics mine).

1022 Volf, "Materiality of Salvation."

1023 On this shift, see Althouse, Spirit of the Last Days; Althouse, "In Appreciation of Jürgen Moltmann.”; Althouse, "Implications of the Kenosis of the Spirit for a Creational Eschatology."
} 
Kingdom theology, which views the coming of the Kingdom in terms of God's justice. This can be extended to ecojustice. To quote Althouse, "The coming kingdom creates possibilities for the present which have transformative and revolutionary power." ${ }^{1024}$ His search for a Pentecostal eschatology responsible for the issues of the age finds a muchneeded conversation source in Jürgen Moltmann, particularly his Theology of Hope. ${ }^{1025}$ In particular, his retrieval of the Latter Rain movement is now important for Pentecostals as it offers an eschatology focused more presently for personal and societal transformation. This move shifts the soteriological focus to the here and now as opposed to the far and off.

\subsection{Summary}

In this constructive chapter I have argued for four novel advances in Pentecostal pneumatology towards ecotheology: the Spirit baptized creation, the Spirit of the charismatic creation, the holistic creational Spirit, and the eschatological Spirit of ecological mission. As it stands, what have been some hurdles we have overcome regarding a fully developed PC ecotheology? Clearly, for PC theology, this burgeoning area of theology represents a kind of maturation, one that has required some amount of struggle. Just as every ecclesial movement or tradition has been forced to struggle to answer the questions regarding creational stewardship and ecological care, PCs have had to do the same. As we have seen, the ecological approaches have varied widely both within and without the PC community. Each ecotheological attempt, similarly, offers a

\footnotetext{
1024 Althouse, Spirit of the Last Days, 111.

1025 Moltmann, Theology of Hope.
} 
unique approach to the biblical narrative. As one recent study has suggested, hermeneutical approaches to ecotheology have often been of one or the other nature: readings that focus on a recovery of the biblical message or readings that resist certain or all elements of the biblical narrative. ${ }^{1026}$ This presents a theological and hermeneutical conundrum for anyone attempting to synthesize a biblical theology to ecological issues. Community contextualization to these issues, as well, presents an entirely separate set of problems and questions. It is without question as to why religious communities have struggled to contextualize themselves in the ecological crisis, as Laura Yordy has pointed out. $^{1027}$

But why have Pentecostals, specifically, struggled with contextualizing ecologically? What has been the challenge to such a theology? From our study, before continuing, I would like to mention three roadblocks which Pentecostal theology appears challenged to transcend. First, I find Simon Chan's thoughtful analysis and critique of Pentecostal tradition helpful here (what he calls "traditioning"). ${ }^{1028}$ Chan's work mirrors my own in a sense; for we are here in essence developing a tradition within Pentecostalism that has little to no ecological tradition; that is, at least not earlier than 1989. Broadly speaking, Chan has recommended that there has been a breakdown in the "traditioning" of the Pentecostal movements—or the methods by which Pentecostal spirituality are passed to the next generation. Chan's words resonate ecologically as they

\footnotetext{
${ }^{1026}$ This is discussed at length in a most helpful recent work that examines a Pauline reading of creation within the broader context of ecotheology, Horrell, Hunt, and Southgate, Greening Paul.

${ }^{1027}$ Yordy suggests four main reasons why the larger church has had a difficult time addressing the ecological crisis: the ineffectiveness of education, the difficulty of implementing real change at the practical level, the relative powerlessness of church officials, and the common vision of a church as a collection of individuals rather than a body. Yordy, Green Witness, 11-12.

${ }^{1028}$ Chan, Pentecostal Theology and the Christian Spiritual Tradition.
} 
do pedagogically. A major roadblock to passing on an ecological tradition is the simple lack of it. Before this "traditioning" can take place, Pentecostals must have something to "tradition" to younger generations, something to pass on. Sadly, on one hand, what ecological traditioning has passed on has been a sense of fear regarding the topic showing itself to struggle with ecological dialogue because it is a part of the so-called "liberal" agenda. ${ }^{1029}$ This has not assisted Pentecostal ecotheology in the slightest. For fear, with all its arrows, never leads to sanctified practice. Yet on a more positive note, perhaps there are benefits to a lack of ecological tradition allowing Pentecostals freedom to be entirely original and fresh in ways perhaps more "traditioned" traditions lack. For sure, an empty journal has more space to write in than a published dictionary. Thus, the Spirit's voice has an empty slate with which to create.

A second roadblock which Pentecostal theology must overcome is that of engaging non-Pentecostal ecological sources, to which we have alluded. As we have illustrated openly and confidently, by definition, Pentecostal ecotheology is willingly open to the Spirit's expression outside Pentecostalism. For the Pentecostal Spirit is one that envisions God's Spirit as being "poured out on all flesh," fulfilling Joel's prophecy. We have attempted to model this in our conversation with three non-Pentecostals and a swath of Christian and non-Christian ecological expressions. We do this convinced that even "liberals" can fall under the category of "all flesh." And if so, it would make sense that Pentecostals have something to learn from anyone (liberal or not), have they something Spirit-illuminated to say in this contemporary situation. That remains the strength of Pentecostal community: to openly accept with wonder the Spirit's voice

${ }^{1029}$ Clifton, "Preaching the 'Full Gospel' in the Context of the Global Environment Crises," 127. 
whether it come from a liberal, conservative, or a donkey owned by Balaam (Num. 22). The Spirit baptized mind, therefore, allows God's Spirit to speak on her own terms through whomever she chooses. This work is offered with sober-mindedness that the future of this area of theology both has a massive need of continued research, but that it will not solve the problems at hand. Rather it will serve as a stimulation point for Pentecostals to begin to find their Spirit-empowered role in the global context of the church and the world. Again, this is by no means intended to take away from seminal Pentecostal efforts in ecotheology. It is rather built on the conviction of God's Spirit in the church and the world. That is, in order to be Pentecostal, Pentecostal theology must be in conversation with non-Pentecostals and the "all flesh" of creation. Otherwise it is not Pentecostal. And God's Spirit is not coredeeming with Christ the creation the Father invented.

Thirdly, a final roadblock Pentecostal ecotheology must and will face is that of a renewed eschatology, or as I call a sustainable eschatology. The historical roots of a near and breaking in eschaton within Pentecostal spirituality have been amply portrayed in a number of seminal publications. ${ }^{1030}$ It was this eschatological view of the coming Christ that fueled a powerful thrust of evangelism, revivalism, and repentance among believers. The Kingdom of God was manifest in unimaginable ways. Yet, the downside of such an eschatology was and is a particular ignorance - in our case ecological. For sadly, holy ecological living has been one of the greatest victims of Pentecostal eschatology. With that said, a Pentecostal ecotheology will ultimately be a critique of such an eschatology on the basis that it lacks a level of long-term sustainability. Unbeknownst to William

${ }^{1030}$ Faupel, The Everlasting Gospel. 
Seymour or Charles Parham, Christ has yet to return in the twenty-first century. What does that say about Pentecostal eschatology? This is by no means to suggest we must abandon a view of the coming Christ in order to care for creation. Nothing could be further from the truth. Rather, the Pentecostal heritage of the coming Christ must be taken more seriously and be placed more centrally in the preaching and practice of Pentecostal theology. Christ is soon to come. It is for that reason we are called to action; and all the more reason to start cleaning up God's green earth. In an age of sustainability, Pentecostal eschatology must be ecologically updated to give Spirit-filled believers an imaginative ability to live righteously, with justice, and ecologically respectful in view of the soon coming Christ. This move towards a more sustainable eschatology must make room for all eschatological visions. For eschatology should be adjudicated not on its predictions of Christ's return but our living in light of Christ's return. Too long has when one predicts the coming Christ to be of importance, overshadowing how one lives in light of it. Pentecostal ecotheology challenges this and suggests the right eschatology has one mark: repentant lifestyles. 


\section{Chapter 7}

\section{CONCLUSION}

We began with an important question in mind: what might a Pentecostal ecotheology actually look like? In answering this research question I have advanced a thesis suggesting a novel approach to Pentecostal ecotheology based on four themes of its pneumatology. This approach gives the Pentecostal community, scholarship, and theological tradition a creative and fresh means to imagine and care for the earth in the twenty-first century context of the ecological crisis. Now that we have arrived at the conclusion of the thesis, it is important to review the overall flow of argument and reflect on how we have arrived at this conclusion. After this overview, I will seek to determine and address major challenges that arise as a result of the project, examine the future possibilities of a Pentecostal ecotheology, offer some practical and ecclesiological implications, and finally close with some brief conclusive remarks.

\subsection{Summary and Significance of the Research Project}

How did we arrive at our conclusion? Chapter 1 outlined the overall intention of the thesis with comment regarding the nature and flow of argument, as well as the methodology. Most importantly, it highlighted a major problem in Pentecostal theology: a perennial struggle to engage societal and justice issues such as the twentieth and twenty-first century ecological crisis. Murray Dempster called this struggle a "social 
quietism." 1031 We examined a number of reasons as to why this "social quietism" has continued to exist in Pentecostal theology regarding the ecological crisis.

For instance, we looked at cultural fear, apocalyptic eschatology, and a Pentecostal connection to Western frameworks as possible reasons behind this quietism. In moving forward, chapter 2 engaged the broader ecumenical context of the ecotheologies of Roman Catholicism, Orthodoxy, Protestantism, and Ecofeminism. Here, we highlighted major themes and theologies that have arisen in these traditions. For instance, we engaged the RC creation theology of Thomas Berry, the mystical Eucharistic theology of the Orthodox tradition, the process-centered theology of Protestant John Cobb, and the linguistic ecological critiques of Ecofeminism. This important task provided a larger context for a more substantive in-depth look at PC ecotheology. Chapter 3 made a significant contribution to the field by examining and critiquing the central PC voices that have shaped Pentecostal ecotheology in the twentyfirst century through their theology of social justice, Spirit/creation theology, and Pentecostal ecotheology. Once we had established the specific field of Pentecostal ecotheology, we identified and examined three dialogue partners who would serve as our representative ecopneumatologies in chapter 4 . Here, we examined and critiqued Denis Edwards's “Biocentric Spirit," Sallie McFague's "Hopeful Spirit," and Mark Wallace's "Wounded Spirit." At the end of chapter 4 we offered a substantive critique from a Pentecostal perspective of each dialogue partner. As we continued into chapter 5, we isolated and examined four themes of a Pentecostal pneumatological framework with which a truly distinctive Pentecostal ecopneumatology could be constructed. These four

${ }^{1031}$ Dempster, "Christian Social Concern in Pentecostal Perspective," 52. 
themes were Spirit baptism, the Spirit of charismatic community, the holistic Spirit, and finally the Spirit of eschatological mission. Then, in chapter 6, we developed a final constructive chapter to build a Pentecostal theology of creation in a pneumatological way.

Broadly, this thesis advances a version of what Amos Yong has called the Pentecostal "pneumatological imagination." 1032 It does so by addressing an agenda for an area not yet fully developed: ecology and the ecological crisis. Of significance, the project offers the first fully developed attempt at a Pentecostal ecotheology from a pneumatological perspective. Similarly, it gives a theological sketch of the ecotheological material developed from a PC perspective for further research. At the onset of the project, I claimed there were two central ways in which I believed this thesis would assist Pentecostalism in the twenty-first century. First, as a preliminary ecological study within PC theology, it will, in hope, create space for further research and study in the area. I have suggested that a Pentecostal ideal of the Spirit-filled life should include involvement in every avenue of the human community: politics, society, science, education, and theology. As Pentecostal communities continue to expand and have influence in every avenue of the human polis, it would be my hope that Pentecostals could more adequately be prepared to serve the created order in which God's Spirit is embodied. My second contention is that this thesis would offer the wider ecumenical community a look at what a Pentecostal ecotheology might actually look like from the outside in. Christian theology, we observed, has since the mid-1960s attempted to construct a valuable theological tradition of earth care and justice. Much of this construction is due to a set of

1032 Yong, Spirit Poured out on all Flesh. 
critiques leveled by Lynn White Jr. and Arnold Toynbee. Now, nearly fifty years later, Pentecostalism is being forced to offer a substantive response. As PC communities continue to be one of the fastest growing Christian communities on a global scale, this thesis will serve to more readily make a Pentecostal expression heard in the global conversation.

\subsection{Challenges to the Thesis}

There are undoubtedly many potential challenges to the thesis I have forwarded. It will be important, therefore, to address such concerns. Four of which I am prepared to discuss here. Firstly, this ecopneumatological advance may appear to suggest to some degree a reductionistic approach to the dynamic relationship of the Spirit to creation. That is, it may appear on the surface to place too closely the Spirit to the life and suffering of the created order. May it be noted that a similar critique was leveled in this thesis regarding Mark Wallace's ecopneumatology in chapter 4. This is the ongoing challenge of any ecotheological model. While we have sought to bring together the Spirit and matter into a more intimate relationship, it is important to make a clear distinction that these two must not be equaled. While the Spirit may embody and vivify creation, we must give heed to the theological notion that God is both transcendent and immanent, above and within the created order. That is, at the moment the Spirit is reduced to simply being in creation as a part of it, it minimizes the cosmological and spiritual scope of omnipresence. God is God and not a created being (Rom. 1:18-25). Likewise, when the Spirit is reduced to a transcendent position, God lives in almost ignorance to the happenings of this world in an Deist-like sense. To alleviate this difficulty we showed that God's Spirit in the Pauline 
usage of a Pentecostal Psalm has "filled the universe" (Eph. 4:10). Yet in the same passage Christ reigns from heaven. The danger thus created in such a venture as this is to equate God's Spirit to the universe it fills. But this will ultimately erroneously forward a cosmological model where God is dangerously dependent on the created world. I would suggest that ultimately, the biblical narrative gives ample space to the notion that God will always be both present in and transcendent above creation. This tension is paramount to understanding God's Spirit within the created order.

Secondly, one might challenge the linguistic choice of "Spirit baptized creation" on the basis that the NT narrative connects Spirit baptism to ecclesial purposes, and not creational purposes. This is a valid critique in many regards. Surely, as best as we can discern, Spirit baptism in Christian experience is a unique work of the Spirit that nonhuman agents in creation do not experience. Nevertheless, again, I believe an accurate reading of Ephesians 4 will correct this bifurcated view and offer a theology of the Spirit filling all creation with her presence and life-giving power in a similar way it does the believer. The reading of Ephesians 4 points at one and the same time the "filling of the universe" and the giving of gifts in the church. In regards to the metaphor of Spirit baptism: to be baptized is simply to be immersed. In our rendering of Pentecostal pneumatology, this Spirit baptism metaphor has profound implications for the community of faith whereby the believer experiences a powerful encounter with the living God. Spirit baptism in the Pentecostal understanding speaks not only to its enlivening and vivifying power, but also the power of witness, healing, and eschatological preparation. When we speak of a Spirit baptized creation, this is not to imply that the Spirit fills the created order in the same way God fills the church for both eschatological and 
kerygmatic witness. But from the creational narratives of Genesis 1 through 3 we are offered a picture of God's Spirit giving life and taking life in every element of the created realm. In this way, we speak of the creation being Spirit baptized. As a word picture utilized by the NT authors, Spirit baptism offers a timely approach to imagining the Spirit for Pentecostal communities.

Thirdly, another may ask why we have not approached this ecotheology topic from a Christological perspective rather than a pneumatological? In chapter 3 we saw Walter Brueggemann speak of the "governing questions of [a] discipline." ${ }^{1033}$ That is, each spiritual tradition will approach any particular subject (such as ecotheology) within the context of their own assumptions, beliefs, and methodological convictions. Pentecostals are no different. They will speak of theology, the church, evangelism, mission, and ecotheology in their own particular Pentecostal way. Thus it appears rather convincing from our assessment of Pentecostal pneumatology that the most helpful approach for a Pentecostal ecotheology would be of a pneumatological nature. As well, in terms of the value of this Pentecostal ecotheology to the ecumenical community, Pentecostals must still bring the pneumatological relish to the conversation: even an ecological conversation. ${ }^{1034}$ Perhaps Pentecostals would respond to those who approach ecotheology from a Christological perspective: why have non-Pentecostals chosen Christology over pneumatology? I would further contend, based on a reading of Luke's charismatic theology outlined so excellently by Roger Stronstad, it is undeniably fair to

\footnotetext{
${ }^{1033}$ Brueggemann, Theology of the Old Testament, 1.

1034 Terry Cross has suggested that in the context of ecumenical dialogue, Pentecostals must not reserve themselves just to bring pneumatology to the theological conversation. In the metaphor of a meal, Pentecostals are urged to bring more than simply a side of relish. Cross, "The Rich Feast of Theology: Can Pentecostals Bring the Main Course or Only the Relish?" JPT 16 (2000), 27-47.
} 
say that any pneumatological theology, especially in a Trinitarian framework, will be inherently a Christological theology. ${ }^{1035}$ For the Spirit in Luke's narrative is Christ's Spirit. Thus a pneumatological Trinitarian approach such as this must claim to be Christological at the same time.

Fourth, and finally, an eschatological challenge may very well be advanced suggesting that an apocalyptic understanding of Christ's return will render any such effort as ecological care as useless. Without reservation, a Pentecostal ecopneumatology will contend that justice, righteousness, and stewardship are never dependent on one's own theology of eschatology. For some in the Pentecostal community, an apocalyptic reading of Christ's return simply is not changeable. Room is made for that in this framework. For it would be nearly impossible to expect an entire eschatological tradition to change or adapt in order to get someone to recycle. With humility we must agree that apocalyptic theologies have as many proof texts as does this project. For them, as the Bible appears to proclaim, it may all very well burn up before the ecological crisis can be fully dealt with. The response of this thesis would be that, nonetheless, the issues of loving our neighbors, feeding the poor, and caring for creation must never be neglected in light of Christ's return. Poor ethics can never be excused because of an eschatological choice. As William Brown showed us, ecological ethics flow out of a healthy cosmological theology. ${ }^{1036}$ Thus, the nearness of Christ's return should usher in a new season of preparation and ethical uprightness. Moltmann rightly reminded us that our eschatological theology

\footnotetext{
1035 Stronstad, The Charismatic Theology of St. Luke.

${ }^{1036}$ Brown, The Ethos of the Cosmos.
} 
should in every way shape our ethical stance of today. ${ }^{1037}$ Simply put, eschatology cannot not shape our ethics. How much more in an ecological setting such as ours?

\subsection{Future Possibilities of a Pentecostal Ecotheology}

John McKay has written, “America's future will abide in a reformed Catholicism and a mature Pentecostalism." ${ }^{1038}$ Clearly, we are seeing in many regards a maturing of the Pentecostal movement in the twenty-first century. Lamar Vest has gone so far as to argue that a development of Pentecostal ecotheology such as this will be a fulfillment of what he believes are eight qualifications of a mature Pentecostalism. ${ }^{1039}$ While what defines a “mature" Pentecostalism remains unclear, undeniably a theological venture into ecology and the ecological crisis may be considered one of them alongside other theological developments. As Pentecostal scholarship and communities continue to examine what a distinctively Pentecostal theology looks like, they will find it in a growing conversation with new worlds of understanding and new areas of research and exploration. So what might the future look like for Pentecostal ecotheology?

Most notably, Pentecostal ecotheology will open new doors of conversation with science. In particular, it will serve as a continuation of an ongoing Pentecostal conversation with scientific communities and their rendering of the interconnected nature of the world described by ecology. We earlier considered the question as to whether we

\footnotetext{
${ }^{1037}$ Moltmann, The Coming of God.

${ }^{1038}$ Quoted in Russell Chandler, Racing toward 2001: The Forces Shaping America's Religious Future (Grand Rapids: Zondervan, 1992), 312. Kärkkäinen writes, "It is fair to say that Pentecostal theology as a systematic enterprise is finally coming of age." Kärkkäinen and Yong, eds., Toward a Pneumatological Theology, xiii.

${ }^{1039}$ Lamar Vest, Spiritual Balance: Reclaiming the Promise (Cleveland: Pathway, 1994).
} 
were to believe that Christian (or Pentecostal) theology might actually have something significant to offer a scientific understanding of natural studies, ecology, or an empirical study of the cosmos in general. ${ }^{1040}$ Again, the answer must remain yes if there is mutual dialogue and humility. ${ }^{1041}$ Yet the answer will always be $n o$ if humility is lacking. Pentecostal ecotheology humbly acknowledges the findings of the ecological community. To their credit, while Pentecostal engagement with ecotheology has not been entirely satisfactory up to now, the scene seems to be changing. ${ }^{1042}$ New and creative theological voices are rising in conversation with science and the social sciences showing renewed humility in these regards. As a Pentecostal pneumatology of creation continues to be developed, it could potentially prove to show similar understandings of the nature of the web of creation with God's Spirit connecting and enlivening life. Now that religious communities and institutions need to situate themselves in relation to science, environmentalism, and other related empirical sciences since the genesis of the American environmental movement in the mid-nineteenth century, a potential return to the science/theology dialogue seems more and more a possibility. ${ }^{1043}$ Thus, a Pentecostal ecopneumatology will continue a strengthened conversation between Pentecostals and science.

\footnotetext{
1040 This is the overall question and eventual discussion in Amos Yong, The Spirit Renews the Face of the Earth: Pentecostal Forays in Science and Theology of Creation, ed. Amos Yong (Eugene: Pickwick, 2009).

${ }^{1041}$ For a significant contribution to the cross-cultural ecotheological discussion we are speaking of, with special attention given to the discussion between the North and the South, see David Hallman, Ecotheology: Voices from South and North (Maryknoll: Orbis, 1994).

${ }^{1042}$ Many evident signs within PC movements point to this. To mention just one, the 2008 joint meeting of the Society for Pentecostal Studies (SPS) and the Wesleyan Theological Society (WTS) emphasized "Sighs, Signs, and Significance," giving attention to many scientific issues being raised today in global, Christian, and Pentecostal discussions.

1043 Carson, Silent Spring. For a helpful primer on Christian understanding of the theology/science dialogue, see Niels Gregersen and Wetzel van Huyssteen, eds., Rethinking Theology and Science: Six Models for Current Dialogue (Grand Rapids: Eerdmans, 1998).
} 
This thesis opens up new avenues of imagination in regards to the life of the Spirit both inside and outside boundaries of the Pentecostal community. This is an important point. For it is somewhat of a return to classic early-twentieth century Pentecostalism that envisioned the Spirit as a transdenominational force. Ecumenism was the brilliance of early Pentecostalism. Honest and open ecumenism, the bridging of Christian communities on the basis of Spirit baptism, was a fresh opening of the understanding of the role of the Spirit in the church. The same might be said of a Pentecostal ecotheology. For in the context of the ecological crisis, a Pentecostal ecopneumatology is a furthered type of ecumenism: what I would call ecological ecumenism. By respecting and caring for the Spirit in creation, we ultimately create a new paradigm of peace where lamb can lie with wolf and child can play with serpent. For in the same way the Spirit could bring together blacks and whites in worship at the Azusa Street revival, the Spirit can bring together human and nonhuman creation to be at peace and shine God's glory in harmony within this new context. Future efforts in Pentecostal ecotheology will continue to give a greater accounting to the developing of human relationship to the created world and foster these life-giving relationships.

In hope, Pentecostal ecotheology will spur on other imaginative theological approaches to broader societal issues that Pentecostalism is facing in the contemporary world. For instance, what could a pneumatological approach be to the issue of human trafficking? Or how might a Pentecostal understanding of the Spirit help heal the Western capitalistic spirit? Or what might Spirit baptism say regarding racial reconciliation? The striking benefit of a Pentecostal pneumatology of the issues that might be raised such as these is how much space there is to create. The horizons are wide open. This allows 
Pentecostalism to expand novel and fresh approaches in ways other traditions may struggle. For sure, up to now, Pentecostal academic ecotheology has been one of the most carbon-friendly ventures in the ecumenical world. And in many ways this may very well have led to an ignorance of important issues the global community is facing. But the benefit remains that so much work continues to be done in Pentecostal theology it gives researchers plenty to do for years.

Many new questions must be raised in the area of Pentecostal ecotheology and a pneumatological reading of creation. What could be some further questions considered in future research?

1. What are the ecological implications of Pentecostal "revivals" such as those in Florida or Toronto? What is the carbon footprint of the travels that are incurred to visit these "revivals"?

2. What is a pneumatological rendering of contemporary ecological models being forwarded in the ecological science of today (e.g. Gaia theory)?

3. How might pneumatology help cosmologists and ecologists understand the interdynamic and interconnected nature of the universe?

4. What are practical ways Pentecostal ecotheology might help foster ecclesial ethics that lead to sustainable practices in local contexts?

5. What are the challenges to developing a Pentecostal ecotheology within the context of its noncentralized ecclesial structure? What are the benefits and pitfalls of this? 
6. What eschatological models in PC theology might be developed that would make more space for social justice issues? What eschatological models hinder these?

7. How has Pentecostal denominationalism affected the overall approach of Pentecostalism in dealing with the ecological crisis?

8. What are the political relationships between PC communities and the ecological movements? What are potential openings or downsides to these relationships?

\subsection{Practical and Ecclesiological Implications of the Research Project}

As we observed in our earlier study, there was an outgrowth of creational writings that came in the wake of Vatican II in RC theology. We very well might similarly see a future of promising avenues to come for Pentecostal theology with its contemporary emphasis on pneumatology. I would contend that when the Holy Spirit is given space in our theological imagination, it will naturally, over time, cause us to look into our relationship to the world around us; especially if we view the Spirit as living within the creation schemata. Nestor Medina, commenting on the lack of Pentecostal creation care, writes, "No doubt part of their [Pentecostals] neglect of environmental issues relates closely with their own eschatology and expectations of the age to come. It is my opinion, however, that iffor Pentecostals all of life is the province of the world of the Spirit, it follows that eschatology does not deny the liability of believers as stewards of creation." ${ }^{1044}$ Medina has illustrated the importance of envisioning the life of the Spirit as the vivifying life of

${ }^{1044}$ Nestor Medina, “Jürgen Moltmann and Pentecostalism(S), 107. 
both creation and the entire world. What are the implications of both this thesis and a pneumatology of the world for Pentecostal practice and ecclesiology?

One very central means to continuing a developed theology of the earth is to rehash the pneumatological heritage that continues to live powerfully in PC history, theology, and practice. But beyond simply having a theology of the Spirit, there must be practical ways in which it can be incarnated. One of the greatest challenges to effective ecological practice is what I call the tyranny of the global. When we face the tyranny of the global, when faced with the daunting responsibility of feeling as though the individual needs to fix the world, many individuals tend to shut down in overwhelming exasperation with the problem at hand. How is one individual Pentecostal going to feel as though they can fix the ecological crisis? Ultimately, the pneumatological approach laid out here will contend that no individual human can fix the created order on their own. Rather, the Spirit of Christ's resurrection power has the ontological ability to sustain and enable such healing. The Spirit heals. And it is through the laying on of hands that this healing is incarnated in the life of creation. A practical implication of the Spirit's healing of creation is that it must happen through the laying on of human hands, in renewed relationship between the stewards of creation and creation itself. And as the relationship between the two is renewed, God's Spirit heals in gracious power.

Many in ecclesial contexts are attempting to renew this relationship. In this way, this thesis will give a theological backing to ecclesial works already in progress. For instance, Tri Robinson, a pastor in the Charismatic Vineyard tradition, has attempted a unique approach to ecotheological practice at his congregation in Boise, Idaho. His Saving God's Green Earth has suggested positive, practical means to ecological justice 
from a Charismatic perspective. ${ }^{1045}$ Robinson's and others works may benefit greatly from a supporting theological approach. Ecclesiologically, developing programs for creation care are difficult for a pastor to initiate who already has a weekly sermon to prepare, pastoral counseling to attend to, and budget meetings to attend. But a Pentecostal charismatic theology will rely on the Spirit-led more than the positional leader. For the one or two individuals in a Pentecostal community who sense a leading to begin a recycling program, ecological justice seminar, or bus-riding program, this theological work will offer a conversation piece in beginning their project.

Similarly, what are the implications for a Pentecostal ecotheology in the preaching ministry of Pentecostal communities? No doubt, the preaching of the gospel message of the death and resurrection of Christ will be the central kerygmatic thrust of the Pentecostal church — and rightly so. Nevertheless, a pneumatology of creation should rightly lead us to preach an ecological message that is greater than simply the admonition to recycle or ride the bus. Pentecostal preaching should more emphatically proclaim the beauty and hallowness of all life. That all life — trees, fish, and unborn children — are all inherently valued by God in his own way. Although challenging on a text-critical level, Mark 16:15 records Jesus telling his disciples to "go into all the world and preach the gospel to all creation." Many, such as St. Francis of Assisi took this assignment very seriously. And so should Pentecostals. As J.T. Snell noted, Pentecostals have been very quick to proof-text Mark 16 in every regard other than the command to preach Christ to

\footnotetext{
1045 Tri Robinson and Jason Chatraw, Saving God's Green Earth: Rediscovering the Church's Responsibility to Environmental Stewardship (Norcross: Ampelon Publishing, 2006).
} 
the creation. ${ }^{1046}$ Thus the command to preach the gospel must rightly be extended not only to the human community but the creational one as well.

Pentecostal education will be an important element of developing an ecological conscience in the twenty-first century. Perhaps a way forward would be for PC Bible Colleges to offer seminars or classes on ecology that deal with the ecological crisis or in a class on contextual theology. The challenge will be to retain a strong-held sense of being distinctively Pentecostal. David Martin, in speaking of the dangers of losing its Pentecostal identity, writes, "Put crudely, Pentecostalism in the developing world is likely to follow a trajectory of incline and decline, until its devotees as too successfully better themselves, relax their vigor, and 'go to school."'1047 Martin alludes to a challenge in Pentecostal education: becoming more ecologically conversant without losing its sense of dynamic identity.

Finally, a Pentecostal ecopneumatology will challenge Pentecostal discipleship efforts that solely focus on baptism in the Spirit for the purposes of speaking in tongues. It will contend that glossolalia is but one element of the Christian conversion process. And that Spirit baptism is the beginning of the process of Christian development. It is the Spirit's work after this in the life of the believer that shapes and molds the kingdom of this world when the Spirit is given space to work, heal, and create.

Pentecostal academia will have profound marks on the global Pentecostal ecological ethic. While a very helpful breakout session is offered on Pentecostal Ethics at the yearly SPS meeting, perhaps a greater level of availability could be given to

\footnotetext{
1046 Snell, "Beyond the Individual and Into the World."

1047 Martin, Pentecostalism, 2.
} 
ecological expressions. As well, it would be a thoughtful contribution if the next revised edition of NIDPCM had an article on Pentecostal ecotheology and ecological ethics.

\subsection{Conclusion}

We have arrived at the end. Reflecting on this project, I must confess that I have found being a Pentecostal scholar an intrepid and often dangerous affair. I have often commented that when we are found out, most Pentecostals and lay-people judge us as heretics for having PhDs and most non-Pentecostal academics think you are brainless for continuing to advocate Spirit baptism. It is a tough place to be. To lessen the worries of my Pentecostal friends, I would like to make it clear that this thesis in no way argues that the initial sign of the baptism of the Holy Spirit is recycling. But it does offer something else. It offers a new awareness of the Spirit in the world-in all of creation that seeks to free it from bondage and decay. It does contend that the Spirit baptized life will always lead to an emphasis of personal piety and righteousness and social piety and righteousness. For the Spirit continues to do its work through those in whom she lives. God's land is a gift. It must be stewarded. Likewise, God's Spirit is a gift. Its gifts must be stewarded - gifts of prophesy, of love, of dreams, and of tongues. But all of God's gifts must be stewarded. Whether these gifts be tongues or trees. 


\section{BIBLIOGRAPHY}

Abbott, T. K. 1897. The Epistles to the Ephesians and the Colossians. International Critical Commentary. Edingburgh: T\&T Clark.

Ables, T. 2008. A ladder leading toward God: Pneumatology and the environmental crisis. A paper presented at the $37^{\text {th }}$ conference of Society for Pentecostal Studies. Raleigh-Durham, North Carolina (March).

Abraham, K. C. 1994. A theological response to the ecological crisis. In Ecotheology: Voices from south and north, ed. Hallman, D., 65-78. Maryknoll: Orbis.

Acosta, M. 2009. Power pentecostalisms: The 'non-catholic' Latin American church is going full steam ahead--but are we on the right track? CT 53.8: 40-42.

Adams, C. 1990. The sexual politics of meat: A feminist-vegetarian critical theory. New York: Continuum.

-----. 2007. Ecofeminism and the sacred. New York: Continuum.

Albrecht, D. 1999. Rites in the Spirit: A ritual approach to pentecostal/charismatic spirituality. JPTSup, vol. 17. Sheffield: Sheffield Academic Press.

Allen, D. 2008. Is the sky falling?: A brief introduction to climate change science. In Christians, the care of creation, and global climate change, ed. Scott, L., 6-23. Eugene: Pickwick.

Allen, D. M. 2000. The unfailing stream: Charismatic movement through the ages. London: Sovereign World Ltd.

Allen, R. J. 2000. Thinking theologically: The preacher as theologian. Minneapolis: Fortress.

Althouse, P. 2003. Spirit of the last days: Pentecostal eschatology in conversation with Jürgen Moltmann. JPTSup, vol. 25. London: T\&T Clark.

------. 2006. In appreciation of Jürgen Moltmann: A discussion of his transformational eschatology. PNEUMA 28.1:21-32

-----. 2009. Implications of the kenosis of the Spirit for a creational eschatology. In The Spirit Renews the Face of the Earth, ed. Amos Yong, 155-172. Eugene: Pickwick.

Anderson, A. 2004. An introduction to Pentecostalism: Global charismatic Christianity. Cambridge: Cambridge University Press.

------. 2005. The dubious legacy of Charles Parham: racism and cultural insensitivities among pentecostals. PNEUMA 27.1: 51-64.

-----. 2006. The hazards of writing a book on global pentecostalism. PNEUMA 28.2: 283-288.

-----. 2007. When is a pentecostal not a pentecostal? When she's a charismatic!

Responding to Irvin, Lopez, Rodriguez and Waldrop. JPT 16.1: 58-63.

Anderson, R. M. 2006. Vision of the disinherited: The making of American pentecostalism. Eugene: Wipf \& Stock.

Archer, K. J. 2004. Pentecostal story: The hermeneutical filter for the making of meaning. PNEUMA 26.1: 36-59.

------. 2004. A pentecostal hermeneutic for the twenty-first century: Spirit, scripture, and community. New York: Continuum.

Arnett, W. 1979. The role of the Holy Spirit in entire sanctification in the writings of John Wesley. WTJ 14: 15-30. 
Arrington, F. 1992. Christian doctrine: A pentecostal perspective. Cleveland: Pathway Publishers.

-----. 1994. The use of the Bible by pentecostals. PNEUMA 16.1: 101-107.

-----. 2003. Encountering the Holy Spirit: Paths of Christian growth and service. Cleveland: Pathway Press.

Asamoah-Gyadu, J. K. 2009. God's law of productivity: Creation in African pentecostal hermeneutics. In The Spirit renews the face of the earth, ed. Amos Yong, 175190. Eugene: Pickwick.

Babcock, G. 1997. Light of truth \& fire of love: A theology of the Holy Spirit. Grand Rapids: Eerdmans.

Bakke, R. 1997. A Theology as big as the city. Downer's Grove: IVP.

Barbour, I. 1974. Myths, models, and paradigms: A comparative study in science and religion. New York: Harper \& Row.

-----. 2002. Nature, human nature, and God. Minneapolis: Fortress.

Barrett, C. K. 1947. The Holy Spirit and the gospel tradition. London: SCM.

Barth, K. 1938. The Holy Spirit in the Christian life: The theological basis of ethics. Trans. Hoyle, R. B. London: F. Mueller.

-----. 1963. Evangelical theology: An introduction. Trans. Foley, G. Grand Rapids: Eerdmans.

Bartholomew, C., and Goheen, M. 2004. The drama of Scripture: Finding our place in the biblical story. Grand Rapids: Baker Academic.

------., and Chryssavgis, J. 2003. Cosmic grace + humble prayer: The ecological vision of the green Patriarch Bartholomew I. Grand Rapids: Eerdmans.

Bartleman, F., and Synan, V. 2006. Azusa street: An eyewitness account. Alachua: Bridge-Logos.

Batstone, D., Mendieta, E., Lorentzen, L., and Hopkins, D. 1997. Liberation theologies, postmodernity, and the Americas. New York: Routledge.

Battley, D. 1986. Charismatic renewal: A view from inside. ER 38.1: 48-56.

Baumert, N. 2004. 'Charism' and 'Spirit-baptism': Presentation of an analysis. JPT 12.2: 147-179.

Baumgärtel, F. 1976. Pneuma. In Theological dictionary of the New Testament, eds. Kittel, G., and Friedrich, G., 332-368. Grand Rapids: Eerdmans.

Bellah, R. et. al. 2008. Habits of the heart: Individualism and commitment in American life. Berkeley: University of California Press.

Bennett, J. 1977. On responding to Lynn White: Ecology and Christianity. OJRS 5.1: 7177.

Berdyaev, N. 1946. Spirit and reality. Trans. Reavey, G. London: Bles.

Berkhof, H. 1964. The doctrine of the Holy Spirit. Richmond: John Knox Press.

Bernstein, E. 2000. Ecology \& the Jewish Spirit: Where nature and the sacred meet. Woodstock: Jewish Lights Publishers.

Berry, R. 2000. The care of creation: Focusing concern and action. Leicester: IVP.

Berry, T. 2006. The dream of the earth. San Francisco: Sierra Club Books.

------., and Tucker M. E. 2006. Evening thoughts: Reflecting on earth as sacred community. San Francisco: Sierra Club Books.

------., Clarke, T., Dunn, S., and Lonergan, A. 1991. Befriending the earth: A theology of reconciliation between humans and the earth. Mystic: Twenty-Third Publications. 
------., Lonergan, A., Richards, C., and Baum, G. 1987. Thomas Berry and the new cosmology. Mystic: Twenty-Third Publications.

Berry, W. 2001. Life is a miracle: An essay against modern superstition. Washington D.C.: Counterpoint.

Bevans, S. 2002. Models of contextual theology. Maryknoll: Orbis.

Bloch-Hoell, N. 1964. The pentecostal movement: Its origin, development, and distinctive character. London: Allen and Unwin.

Bloom, H. 1992. The American religion. New York: Simon and Shuster.

Blumhardt, J. 1978. Ansprachen, Predigten, Andacten, Und Schriften, ed. Harder, J., vol. 1. Neukirchen-Vluyn: Neukirchener Verlag.

Blumhofer, E. W. 1993. Aimee Semple Mcpherson: Everybody's sister. Grand Rapids: Eerdmans.

Boff, L. 1986. Way of the cross: Way of justice. Maryknoll: Orbis.

------., and Boff, C. 1984. Salvation and liberation. Maryknoll: Orbis.

------., and Cumming, J. 1995. Ecology and liberation: A new paradigm. Maryknoll: Orbis.

------., and Elizondo, V. 1995. Ecology and poverty: Cry of the earth, cry of the poor. Maryknoll: Orbis.

Boone, J. 2009. Created for shalom: Human agency and responsibilty in the world. In The Spirit renews the face of the earth, ed. Amos Yong, 17-29. Eugene: Pickwick.

Booth-Clibborn, A. 1914. Blood against blood. New York: Doran.

Botkin, D. 2001. No man's garden: Thoreau and a new vision for civilization and nature. Washington D.C.: Island Press for Shearwater Books.

Bouma-Prediger, S. 1995. The greening of theology: The ecological models of Rosemary Radford Ruether, Joseph Sittler, and Jürgen Moltmann. Atlanta: Scholars Press.

------. 2001. For the beauty of the earth: A Christian vision for creation care. Grand Rapids: Baker Academic.

------., and Vroblesky, V. 1997. Assessing the ark: A Christian perspective on non-human creatures and the endangered species Act. Wynnewood: Crossroads.

Bratton, S. P. 1988. The original desert solitaire: Early Christian monasticism and wilderness. EE 10: 31-53.

Brown, S. C. 2005. Can physics contribute to theology? ZY 40.2: 495-501.

Brown, W. P. 1999. The ethos of the cosmos: The genesis of moral imagination in the Bible. Grand Rapids: Eerdmans.

Bruce, F. F. 1963. The epistle of Paul to the romans: An introduction and commentary. Grand Rapids: Eerdmans.

Brueggemann, W. 1997. Theology of the Old Testament: Testimony, dispute, advocacy. Minneapolis: Fortress.

Brumback, C. 1947. What meaneth this? Springfield: Gospel Publishing House.

------. 1961. Suddenly... from heaven. Springfield: Gospel Publishing House.

Bruner, E. 1953. The misunderstanding of the church. Philadelphia: Westminster.

-----. 1988. Das missverstandnis der kirche. Zurich: Theologischer Verlag Zurich.

Bruner, F. 1970. A theology of the Holy Spirit: The pentecostal experience and the New Testament witness. Grand Rapids: Eerdmans.

Buber, M. 1958. I and Thou. New York: Scribner. 
Burgess, S. M., and M. van der Maas, E. 1988. Dictionary of pentecostal and charismatic movements. Grand Rapids: Zondervan.

-----. 1989. The Holy Spirit. 3 vols. Peabody: Hendrickson.

------, and M. van der Maas, E. 2002. The new international dictionary of pentecostal and charismatic movements. Rev and expanded ed. Grand Rapids: Zondervan.

Burr, L. 1987. Mennonites and the ecological crisis. Elkhart: L. M. Burr.

Caird, G. 1964. The descent of Christ in ephesians 4:7-11. SE 2: 535-45.

Campenhausen, H. F. 1997. Ecclesiastical authority and spiritual power in the church of the first three centuries. Peabody: Hendrickson.

Cannon, K., Isasi-Diaz, A., Piu-lan, K. and Russell, L. 1988. Inheriting our mothers' gardens: Feminist theology in third world perspective. Philadelphia: Westminster.

Capra, F. 2002. The hidden connections: A science for sustainable living. New York: Anchor.

Carmody, J. 1983. Ecology and religion: Toward a new Christian theology of nature. New York: Paulist.

Carrol, J., and LaChance, A. 1994. Embracing earth: Catholic approaches to ecology. Maryknoll: Orbis.

Carson, R. 2002. Silent Spring. New York: Mariner.

Cartledge, M. J. 2001. Charismatic glossolalia: An empirical-theological study. Aldershot: Ashgate.

------. 2006. Encountering the Spirit: The charismatic tradition. London: Darton Longman \& Todd.

Chan, S. 1998. Spiritual theology: A systematic study of the Christian life. Downer's Grove: IVP.

------. 2000. Mother church: Toward a pentecostal ecclesiology. PNEUMA 22.2: 177-208.

------. 2000. Pentecostal theology and the Christian spiritual tradition. JPTSup, vol. 21. Sheffield: Sheffield Academic Press.

Chandler, R. 1992. Racing toward 2001: The forces shaping America's religious future. Grand Rapids: Zondervan.

Chant, B. 1982. The promise of the charismatic movement. In The shape of belief: Christianity in Australia today. Eds. Harris, D., Hynd, D., and Millikan, D., 109122. Homebush West: Lancer.

Chapple, C. 2000. Hinduism and ecology: The intersection of earth, sky, and water. Cambridge: Harvard University Press.

Charette, B. 2000. Restoring presence: The Spirit in matthew's gospel. JPTSup, vol. 18. Sheffield: Sheffield Academic Press.

Cheek, D. 1992. Thinking constructively about science, technology, and society education. Albany: State University of New York Press.

Christenson, L. 1968. Speaking in tongues. Minneapolis: Dimension Books.

-----. 1974. A charismatic approach to social action. Minneapolis: Bethany Fellowship.

------. 1975. Pentecostalism's forgotten forerunner. In Aspects of pentecostal-charismatic origins, ed. Synan, V., 15-37. Plainfield: Logos International.

-----. 1976. Social action Jesus style. Minneapolis: Bethany Fellowship.

Clayton, P. 2004. Mind \& emergence: From quantum to consciousness. Oxford: Oxford University Press. 
Cleary, E., and Sepulveda, J. 1997. Chilean pentecostalism: Coming of age. In Power, politics, and pentecostals in Latin America. Eds. Cleary, E., and Gambino, S., 97121. Boulder: Westview.

Clifton, S. 2007. The Spirit and doctrinal development: A functional analysis of the traditional pentecostal doctrine of the baptism in the Holy Spirit. PNEUMA 29.1: $5-23$.

-----. 2009. Preaching the 'full gospel' in the context of the global environment crisis. In The Spirit renews the face of the earth, ed. Amos Yong, 117-134. Eugene: Pickwick.

Clines, D. J. 1989. Job 1-20. Word Biblical Commentary, vol. 17. Waco: Word.

Coakley, S. 1988. 'Femininity' and the Holy Spirit. In Mirror to the church, ed. Furlong, M., 124-135. London: SPCK.

Coalition on the Environment and Jewish Life. 1995. To till and to tend: A guide to Jewish environmental study and action. New York: Coalition on the Environment and Jewish Life.

Cobb, J. 1965. A Christian natural theology: Based on the thought of Alfred North Whitehead. Philadelphia: Westminster.

-----. 1975. Christ in a pluralistic age. Philadelphia: Westminster.

-----. 1994. Sustaining the common good: A Christian perspective on the global economy. Cleveland: Pilgrim.

-----. 1996. Is it too late?: A theology of ecology. Denton: Environmental Ethics Books.

-----. 1998. God and the world. Eugene: Wipf and Stock.

Coffey, D. 2001. The Spirit of Christ as entelechy. PTH 13.2: 363-398.

Cohen, A. 1988. Thinking the tremendum: Some theological implications of the deathcamps. New York: Crossroad.

Collier, M, and Webb, R. 2002. Floods, droughts, and climate change. Tucson: University of Arizona Press.

Comblin, J, and Berryman, P. 1998. Called for freedom: The changing context of liberation theology. Maryknoll: Orbis.

-----. 1989. The Holy Spirit and liberation. Maryknoll: Orbis.

Congar, Y. 2001. I believe in the Holy Spirit. 3 vols. New York: Crossroad Publishing.

Conradie, E. 2005. Towards an agenda for ecological theology: An intercontinental dialogue. ECO 10.3: 281-343.

Conzelmann, H. 1960. Die mitte der zeit: Studien zur theologie des Lukas. Tubingen: J.C.B. Mohr.

Corten, A., and Ruth M. 2001. Between babel and pentecost: Transnational pentecostalism in Africa and Latin America. Bloomington: Indiana University Press.

Covington, D. 1995. Salvation on sand mountain: Snake handling and redemption in Southern Appalachia. New York: Penguin.

Cox, H. G. 1965. The secular city: Secularization and urbanization in theological perspective. New York: Macmillan.

-----. 1995. Fire from heaven: The rise of pentecostal spirituality and the reshaping of religion in the twenty-first century. Reading: Addison-Wesley.

Cross, F., and Livingstone, E. 1985. The oxford dictionary of the Christian church. Oxford: Oxford University Press. 
Cross, T. 2000. The divine-human encounter towards a pentecostal theology of experience. PNEUMA 31.1: 3-34.

------. 2000. The rich feast of theology: Can pentecostals bring the main course or only the relish? JPT 16: 27-47.

-----. 2006. A response to Clark Pinnock's 'a church in the power of the Spirit'. JPT 14.2: $175-182$.

Cummings, C. 1991. Eco-spirituality: Toward a reverent life. Mahwah: Paulist.

Curry, P. 2006. Ecological ethics: An introduction. Cambridge: Polity.

Dabney, L. 1996. Otherwise engaged in the Spirit: A first theology for a twenty-first century. In Future of theology, ed. Volf, M., Krieg, C., and Kucharz, T., 154-163. Grand Rapids: Eerdmans.

------. 2001. Naming the Spirit: Towards a pneumatology of the cross. In Starting with the Spirit, eds. Pickard, S., and Preece, G., 28-59. Hindmarsh.

-----. 2001. Saul's armor: The problem and the promise of pentecostal theology today. PNEUMA 23.1: 115-146.

------. 2006. The nature of the Spirit: Creation as a premonition of God. In Work of the Spirit, ed. Welker, M., 71-86. Grand Rapids: Eerdmans.

-----. 1990. Ecofeminism, reverence for life, and feminist theological ethics. In Liberating Life, eds. Birch, C., Eakin, W., and McDaniel, J., 88-108. Maryknoll: Orbis.

Daneel, M. L. 1987. Quest for belonging: Introduction to a study of African independent churches. Mambo Occasional Papers, Vol. 17. Gweru: Mambo Press.

-----. 2000. Earth-keeping churches at the African grass roots. In Christianity and ecology, eds. Hessel, D., Ruether, R., 531-552. Cambridge: Harvard University Press.

------. 2003. Liberative ecumenism at the African grassroots. In Full of life for all: Challenges for mission in the 21st century, eds. Daneel, M. L., Van Engren, C., and Vroom, H., 295-327. New York: Rodopi.

------ 1991. Towards a sacramental theology of the environment in African independent churches. TE 24: 2-26.

Dayton, D. 1987. Theological roots of pentecostalism. Peabody: Hendrickson.

De Walle, V. 2009. Cautious co-belligerence?: The late nineteenth-century American divine healing movement and the promise of medical science. In The Spirit renews the face of the earth, ed. Amos Yong, 53-73. Eugene: Pickwick.

Deane-Drummond, C. 2006. Pierre Teilhard de Chardin on people and planet. London: Equinox.

Dempster, M. 1987. Pentecostal social concern and the biblical mandate of social justice. PNEUMA 9.2: 129-153.

-----. 1991. Evangelism, social concern, and the kingdom of God. In Called \& empowered: Global mission in pentecostal perspective, eds. Dempster, W., Klaus, B., Peterson, D., 22-43. Peabody: Hendrickson.

-----. 1993. Christian social concern in pentecostal perspective: Reformulating pentecostal eschatology. JPT 2: 51-64.

------. 1994. Church mission and social concern: The changing global face of classical pentecostalism. TR 11: 1-32.

------. 1999. A pentecostal approach to evangelization and social concern. TR 16: 41-66. 
-----. 1999. social concern in the context of Jesus's kingdom, mission, and ministry. $T R$ 16: 43-53.

-----. 2001. Pacifism in pentecostalism: The case of the assemblies of God. In Fragmentation of the church and its unity in peacemaking, eds. Gros, J. and Rempel, J., 137-165. Grand Rapids: Eerdmans.

------., Klaus, B., and Petersen, D. 1991. Called \& empowered: Global mission in pentecostal perspective. Peabody: Hendrickson.

------., Klaus, B., and Petersen, D. 1999. The globalization of pentecostalism: A religion made to travel. Oxford: Regnum Books.

Dermawan, A. 2003. The Spirit in creation and environmental stewardship: A preliminary pentecostal response toward ecological theology. AJPS 6.2: 199-217.

DeWitt, C. B. 1991. The environment and the Christian: What does the New Testament say about the environment? Grand Rapids: Baker.

------., Baer, R., Derr, T., Ehlers, V., Skillen, J., and Lugo, L. 1998. Caring for creation: Responsible stewardship of God's handiwork. Grand Rapids: Baker.

Di Gregorio, M. A. 2005. From here to eternity: Ernst Haeckel and scientific faith. Theologie Und Naturwissenschaft, Vol. 3. Gottingen: Vandenhoeck \& Ruprecht.

Djupe, P. A., and Hunt, P. K. 2009. Beyond the Lynn White thesis: Congregational effects on environmental concern. JSSR 48.4: 670-686.

Duchrow, U., and Liedke, G. 1989. Shalom: Biblical perspectives on creation, justice and peace. Geneva: WCC Publications.

Duffield, G. P., and Van Cleave, N. M. 1983. Foundations of pentecostal theology. Los Angeles: L.I.F.E. Bible College.

Dunn, J. 1970. Baptism in the Holy Spirit: A re-examination of the New Testament teaching on the gift of the Spirit. Philadelphia: Fortress.

-----. 1975. Jesus and the Spirit: A story of the religious and charismatic experience of Jesus and the first Christians as reflected in the New Testament. London: SCM.

-----. 1993. Baptism in the Holy Spirit: A response to pentecostal scholarship on LukeActs. JPT 3: 3-27.

-----. 1998. The Christ and the Spirit: Collected essays of James D.G. Dunn: Pneumatology. Vol. 2. Grand Rapids: Eerdmans.

Eaton, H. 2005. Introducing ecofeminist theologies. Introductions in Feminist Theology, vol. 12. New York: T\&T Clark.

Edwards, D. 1983. Human experience of God. New York: Paulist.

-----. 1991. Jesus and the cosmos. Mahwah: Paulist.

-----. 1992. Made from stardust: Exploring the place of human beings within creation. North Blackburn.: Collins Dove.

-----. 1995. Jesus the wisdom of God: An ecological theology. Maryknoll: Orbis.

-----. 1999. The ecological significance of God-language. TS 60.4: 708-722.

-----. 1999. The God of evolution: A trinitarian theology. New York: Paulist.

-----. 2004. A relational and evolving universe unfolding within the dynamism of the divine communion. In In whom we live and move and have our being, eds. Clayton, P., and Peacocke, A. Grand Rapids: Eerdmans.

-----. 2004. 2007. Breath of life: A theology of the creator Spirit. Maryknoll: Orbis.

-----. 2006. Every sparrow that falls to the ground: The cost of evolution and the Christevent. ECO 11.1: 103-123. 
-----. 2006. Resurrection and the costs of evolution: A dialogue with Rahner on noninterventionist theology. TS 67.4: 816-833.

-----. 2007. Ecology at the heart of faith: The change of heart that leads to a new way of living on earth. Maryknoll: Orbis.

-----. 2008. Eucharist and ecology: Keeping memorial of creation. WSH 82.3: 192-213.

Efthimiou, M. B. 1994. Orthodoxy and the ecological crisis. In Ecotheology: Voices from the south and north, ed. Hallman, D., 92-95. Maryknoll: Orbis.

Ehrenfeld, D. 1978. The arrogance of humanism. Oxford: Oxford University Press.

Elderly, H. 1988. Treasures new and old: Interpretations of 'spirit-Baptism' in the charismatic renewal movement. Peabody: Hendrickson.

Ellul, J. 1973. Technological society. New York: Alfred A. Knopf.

Engel, D. E. 1970. Elements in a theology of environment. ZY 5.3: 216-228.

Ervin, H. M. 1985. Conversion-initiation and the baptism in the Holy Spirit. Peabody: Hendrickson.

-----. 1985. Hermeneutics: a pentecostal option. In Essays on apostolic themes: studies in honour of Howard M. Ervin, ed. Elbert, P., 23-35. Peabody: Hendrickson.

-----. 1987. Spirit baptism: A biblical investigation. Peabody: Hendrickson.

Faupel, D. W. 1993. Whither pentecostalism. PNEUMA 15.1: 9-27.

-----. 1996. The everlasting gospel: The significance of eschatology in the development of pentecostal thought. JPTSup, vol. 10. Sheffield: Sheffield Academic Press.

Fee, G. D. 1976. Hermeneutics and historical precedent - a major problem in pentecostal hermeneutics. In Perspectives on the new pentecostalism, ed. Spittler, R., 118-32. Grand Rapids: Baker.

-----. 1985. 1976. Baptism in the Holy Spirit: The issue of seperability and subsequence. PNEUMA 7.2: 87-100.

-----. 1994. God's empowering presence: The Holy Spirit in the letters of Paul. Peabody: Hendrickson.

Fergeson, S. B. 1996. The Holy Spirit. Downer's Grove: IVP.

Fettke, S. 2008. The Spirit of God hovered over the waters: creation, the local church, and the mentally and physically challenged, a call to Spirit-led ministry. In 37th Annual Meeting of the Society for Pentecostal Studies. Duke University, RaleighDurham, NC (March).

Feynman, R. 1999. The pleasure of finding things out: The best short works of Richard P. Feynman. Cambridge: Perseus.

Fitch, D. E. 2005. The great giveaway: Reclaiming the mission of the church. Grand Rapids: Baker.

Fitzmyer, J. A. 1981. The gospel according to Luke I-IX. New York: Doubleday.

-----. 1993. Romans: A new translation with introduction and commentary. New York: Doubleday.

Flannery, T. F. 2007. The eternal frontier: An ecological history of North America and its peoples. London: Penguin.

Foltz, R., Denny, F. M., and Haji, B. A. 2003. Islam and ecology: A bestowed trust. Cambridge: Center for the Study of World Religions Harvard Divinity School.

Fowler, R. B. 1995. The greening of protestant thought. Chapel Hill: University of North Carolina Press. 
Fox, M, and Sheldrake, R. 1996. Natural grace: Dialogues on creation, darkness, and the soul in spirituality and science. New York: Doubleday.

------. 1980. The coming of the cosmic Christ: The healing of mother earth and the birth of a global renaissance. San Francisco: Harper Collins.

-----. 2000. Original blessing: A primer in creation spirituality. New York: Putnam.

Franklin, E. 1975. Christ the Lord: A study of the purpose and theology of Luke-Acts Philadelphia: Westminster.

Fritsch, A. J. 1994. Appropriate technology and healing the earth. In Embracing earth: Catholic approaches to ecology, eds. LaChance, A., and Carrol, J., 96-114. Maryknoll: Orbis.

Gabriel, A. K. 2007. Pneumatological perspectives for a theology of nature: The Holy Spirit in relation to ecology and technology. JPT 15.2: 195-212.

------. 2008. Beyond the cross: Moltmann's crucified God, Rahner's rule, and pneumatological implications for a trinitarian doctrine of God. DA 19.1: 93-111.

Gallagher, R. L. 2006. The Holy Spirit in the world: In non-Christians, creation and other religions. AJPS 9.1: 17-33.

------., and Hertig, H., eds. 2004. Mission in Acts: ancient narratives in contemporary contexts. Maryknoll: Orbis.

Ganssle, G. E., and Woodruff, D. M., eds. 2002. God and time: Essays on the divine nature. New York: Oxford University Press.

Gasque, W. 1989. A history of the interpretation of the Acts of the apostles. Peabody: Hendrickson.

Gause, R. H. 2006. A pentecostal response to Pinnock's proposal. JPT 14.2: 183-188.

Gee, D. 1932. Pentecost. Springfield: Gospel Publishing House.

Gelpi, D. L. 1984. The divine mother: A trinitarian theology of the Holy Spirit. Lanham: University Press of America.

------. 1992. The theological challenge of charismatic spirituality. PNEUMA 20.2: 185197.

-----. 1994. The turn to experience in contemporary theology. New York: Paulist.

------. 2001. The gracing of human experience: Rethinking the relationship between nature and grace. Collegeville: Liturgical Press.

Gernert, M. O. 2000. Pentecost confronts abuse. JPT 17: 117-130.

Giddens, A. 2009. The politics of climate change. Malden: Polity.

Gillett, G, and Peacocke, A. 1987. Persons and personality: A contemporary enquiry. Oxford: Basil Blackwell.

Girard, R. 1977. Violence and the sacred. Baltimore: Johns Hopkins University Press.

Gottlieb, R. S. 1999. A Spirituality of resistance. New York: Crossroad.

-----. 2004. This sacred earth: Religion, nature, environment. New York: Routledge.

------. 2006. A greener faith: Religious environmentalism and our planet's future. Oxford: Oxford University Press.

Granberg-Michaelson, W. 1984. A worldly spirituality: The call to take care of the earth. San Francisco: Harper \& Row.

-----. 1987. Tending the garden: Essays on the gospel and the earth. Grand Rapids: Eerdmans.

------. 1988. Ecology and life: Accepting our environmental responsibility. Waco: Word Books. 
-----. 1990. Covenant and creation. In Liberating life, eds. Birch, C., Eakin, W., and McDaniels, J., 27-36. Maryknoll: Orbis.

Gray, E. 1981. Green paradise lost. Wellesley: Roundtable.

-----. 1979. Why the green nigger?: Re-mything Genesis. Wellesley: Roundtable Press.

Grazer, W. E. 2000. Strategy for environmental engagement: building a catholic constituency. In Christianity and ecology: Seeking the well-being of earth and humans, eds. Hessel, D., and Ruether, R., 578-587. Cambridge: Harvard University.

Green, L. 1994. Earth age: A new vision of God, the human, and the earth. New York: Paulist.

Gregersen, N. H. 2001. The cross of Christ in an evolutionary world. DIA 40.3: 192-207.

------., and van Huyssteen, W., eds. 1998. Rethinking theology and science: Six models for current dialogue. Grand Rapids: Eerdmans.

Gregorios, P. M. 1978. The human presence: An orthodox view of nature. Geneva: WCC Publications.

------. 1994. New Testament foundations for understanding the creation. In Liberating Life, eds. Birch, C., Eakin, W., and McDaniels, J., 83-92. Maryknoll: Orbis.

Griffin, S. 1978. Women and nature: The roaring inside her. New York: Harper \& Row.

Gros, J., and Rempel, J. D. 2001. The fragmentation of the church and its unity in peacemaking. Grand Rapids: Eerdmans.

Gunton, C. E. 1993. The one, the three, and the many: God, creation, and the culture of modernity. Cambridge: Cambridge University Press.

Guthrie, D. 1981. New Testament theology. Downer's Grove: IVP.

Gutierrez, G. 1973. A theology of liberation: History, politics, and salvation. New York: Orbis.

Habgood, J. 1990. A sacramental approach to environmental issues. In Liberating Life, ed. Birch, C., Eakin, W., McDaniels, J., 46-53. Maryknoll: Orbis.

Haeckel, E. 1876. The history of creation. Trans. Lankester, E. R. Vol. 2. New York: D. Appleton.

Hall, D. J. 1990. The steward: A biblical symbol come of age. Grand Rapids: Eerdmans.

Hallman, D. G. 1994. Ecotheology: Voices from south and north. Maryknoll: Orbis.

Harris, W. H. 1994. The ascent and descent of Christ in ephesians 4:9-10. BibS 151.602: 198-214.

------. 1996. The descent of Christ: Ephesians 4:7-11 and traditional Hebrew imagery. Grand Rapids: Baker.

Haught, J. F. 1993. The promise of nature: Ecology and cosmic purpose. Mahwah: Paulist.

-----. 2002. Religious and cosmic homelessness: Some environmental implications. In Liberating Life, eds. Birch, C., Eakin, W., McDaniels, J., 159-181. Maryknoll: Orbis.

Hawking, S. 1988. A Brief History of Time. New York: Bantam.

Hefner, P. J., Tabler, C., and Martin-Dent, M. 1993. Caring for creation: Vision, hope, and justice: Proposed social statement, division for church in society. $D G$ 32.3: 224-228.

Hegel, G. W. 1962. Lectures on the philosophy of religion. London: Routledge \& Paul. 
Her, J. 2002. A dynamic reading of the Holy Spirit in Luke-Acts. London: Sheffield Academic Press.

Heschel, A. J. 1993. God in search of man: A philosophy of Judaism. New York: Noonday.

Hessel, D. T., Ruether, R. R., eds. 2000. Christianity and ecology: Seeking the well-being of earth and humans. Cambridge: Harvard University Press.

Hick, J. 1966. Evil and the God of love. London: Macmillan.

Hiers, R. H. 1984. Ecology, biblical theology, and methodology: Biblical perspectives on the environment. $Z Y$ 19.1: 43-59.

Higgons, J. R., Dusing, M. L., and Tallman, F. D. 1994. An introduction to theology: A classical pentecostal perspective. Dubuque: Kendall/Hunt Publishing Co.

Himes, M. J., and Himes, K. R. 1995. The sacrament of creation: Toward an environmental theology. In Readings in ecology and feminist theology, 270-283. Kansas City: Sheed \& Ward.

Hindley, J. C. 1966. The Christ of creation in New Testament theology. IJT 15.3: 89-105.

Hinze, C. F. 1996. Catholic social teaching and ecological ethics. In And God saw that it was good, eds. Christiansen, D., and Grazer, W., 165-182. Washington, D.C.: United States Catholic Conference.

Hittenberger, J., and Mittelstadt, M. 2008. Power and powerlessness in pentecostal theology: A review essay on Amos Yong's Theology and down syndrome:

Reimagining disability in late modernity. PNEUMA 30: 137-145.

Hobgood-Oster, L. 2008. Holy dogs and asses: Animals in the Christian tradition. Urbana: University of Illinois.

Hocken, P. 1985. The meaning and purpose of 'baptism in the Spirit'. PNEUMA 7.2: 125-134.

-----. 2005. Baptized in Spirit - an eschatological concept: A response to Norbert Baumert and his interlocutors. JPT 13.2: 257-268.

Hodgson, P. C. 1994. Winds of the Spirit: A constructive Christian theology. Louisville: Westminster John Knox Press.

Hoehner, H. W. 2002. Ephesians: An exegetical commentary. Grand Rapids: Baker.

Hofstadter, R. 1974. Anti-Intellectualism in American life. New York: Knopf.

Holl, A. 1997. The left hand of God: A biography of the Holy Spirit. Trans. John Cullen. New York: Doubleday.

Hollenweger, W. J. 1977. The pentecostals. Minneapolis: Augsburg.

------ 1978. Creator Spiritus: The challenge of pentecostal experience to pentecostal theology. Th 81: 32-40.

------ 1981. Towards a church renewed and united in the Spirit. In Church is charismatic, ed. Bittlinger, A., 21-28. Geneva: WCC.

------. All creatures great and small: Towards a pneumatology of life. In Strange gifts?: A guide to charismatic renewal, eds. Martin, D., and Mullen, P., 41-53. Oxford: Blackwell.

-----. 1986. Pentecostals and the charismatic movement. In The study of spirituality, eds. Jones, C., Wainwright, G., and Yarnold, E., 449-454 New York: Oxford.

------. 1988. Geist und materie: Inerkulturelle theology. Vol. 3. Munich: Kaiser Verlag. 1992. The critical tradition of pentecostalism. JPT 1: 7-17. 
-----. 1997. Pentecostalism: Origins and developments worldwide. Peabody:

Hendrickson.

-----. 2001. Pentecostalism, past, present, and future. JEPTA 21: 41-48.

Hollingsworth, A. 2007. Spirit and voice: Toward a feminist pentecostal pneumatology. PNEUMA 29.2: 189-213.

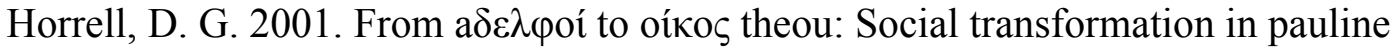
Christianity. JBL 120.2: 293-311.

-----. 2010. The Bible and the environment: Towards a critical ecological biblical theology. Oakville: Equinox.

Horrell, D. G., Hunt, C., and Southgate, C. 2010. Greening Paul: Rereading the apostle in a time of ecological crisis. Waco: Baylor University Press.

Horton, S. M. 1994. Systematic theology: A pentecostal perspective. Springfield: Logion Press.

Houghton, J. T. 2004. Global warming: The complete briefing. Cambridge: Cambridge University Press.

Hummel, C. E. 1978. Fire in the fireplace: Contemporary charismatic renewal. Downer's Grove: IVP.

Humphrey, E. 2006. Ecstacy and intimacy: When the Holy Spirit meets the human spirit. Grand Rapids: Eerdmans.

Hunter, H. D. 1983. Spirit-Baptism: A pentecostal alternative. Lanham: University Press of America.

-----. 2000. Pentecostal healing for God's sick creation? SC 2.2: 145-167.

-----.., and Hocken, H. 1993. All together in one place: Theological papers from the Brighton conference on world evangelization. Sheffield: Sheffield Academic Press.

Hurtado, L. 1991. Normal, but not the norm: 'Initial evidence' and the New Testament. In Initial evidence: Historical and biblical on the pentecostal doctrine of Spirit baptism, ed. McGee, G., 189-201. Peabody: Hendrickson.

International Panel on Climate Change. 2007. Climate change 2007: Impacts, adaptations, and vulnerability. Cambridge: Cambridge University Press.

Jacobsen, D. 1999. Knowing the doctrine of pentecostals: The scholastic theology of the assemblies of God: 1930-1955. In Pentecostal currents in American protestantism, ed. Blumhofer, E., Spittler, R., and Wacker, G., 90-107. Urbana: Univerisity of Illinois Press.

-----. 2003. Thinking in the Spirit: Theologies of the early pentecostal movement. Bloomington: Indiana University Press.

-----., and Trollinger, W. 1998. Re-Forming the center: American protestantism, 1900 to the present. Grand Rapids: Eerdmans.

Jegen, C. 1999. Review of the God of evolution: A trinitarian theology. RE 94.4: 464465.

Jenkins, P. 2002. The next christendom: The coming of global Christianity. Oxford: Oxford University Press.

-----. 2006. The new faces of Christianity: Believing the Bible in the global South. Oxford: Oxford University Press.

John Paul, Pope II. 1986. The Holy Spirit in the life of the church. Boston: St. Paul.

-----. 1988. Sollicitudo rei scialis: On Social Concerns. Homebush: St. Paul Productions. 
Johns, C. B. 1993. Pentecostal formation: A pedagogy among the oppressed. JPTSup, vol. 2. Sheffield: Sheffield Academic Press.

------. 1995. The adolescence of pentecostalism: In search of a legitimate sectarian identity. PNEUMA 17.1:3-17.

-----. 1999. Partners in scandal: Wesleyan and pentecostal scholarship. PNEUMA 21: 183-197.

Johnson, E. A. 1993. Women, earth, and creator Spirit. New York: Paulist.

-----. 1997. She who is: The mystery of God in feminist theological discourse. New York: Crossroad.

------. 2000. Losing and finding faith in the Christian tradition. In Christianity and ecology: Seeking the well-being of earth and humans, eds. Hessel, D., and Ruether, R., 3-21. Cambridge: Harvard University Press.

Johnson, L. T. 1991. Gospel of Luke. Collegeville: Liturgical Press.

-----. 1998. Imagining the world scripture imagines. MT 14.2: 165-180.

Jones, C., Wainwright, G., and Yarnold, E., eds. 1986. The study of spirituality. New York: Oxford.

Jung, C. G. 1958. Undiscovered self. Boston: Little Brown.

Kamlah, E. 1978. Spirit. In Dictionary of New Testament theology, ed. Brown, C., vol. 3, 690-92. Grand Rapids: Zondervan.

Kammer, F. 1991. Doing faithjustice: An introduction to catholic social thought. New York: Paulist.

Kant, I. 1960. Religion within the limits of reason alone. New York: Harper.

Kärkkäinen, V., and Yong, A., eds. 2002. Toward a pneumatological theology. Lanham: University of America Press.

-----. 2002. Introduction to ecclesiology: Ecumenical, historical \& global perspectives. Downer's Grove: IVP.

------. 2002. Pneumatology: The Holy Spirit in ecumenical, international and contextual perspective. Grand Rapids: Baker Academic.

------ 2004. The working of the Spirit of God in creation and in the people of God: The pneumatology of Wolfhart Pannenberg. PNEUMA 26.1: 17-35.

------. 2006. How to speak of the Spirit among religions: Trinitarian prolegomena for a pneumatological theology of religions. In Work of the Spirit, ed. Welker, M., 4770. Grand Rapids: Eerdmans.

Kaufman, G. D. 1985. Theology for a nuclear Age. Louisville: Westminster.

Kearns, L. 2004. The context of eco-theology. In The Blackwell companion to modern theology, ed. Jones, G., 465-484. New York: Blackwell.

Keller, C. 1993. Talk about the weather: The greening of eschatology. In Ecofeminism and the sacred, ed. Adams, C., 30-49. New York: Continuum.

Kelsey, M. 1987. Encounter with God: A theology of Christian experience. New York: Paulist.

Kerr, D. A. 1991. 'Come Holy Spirit--renew the whole creation': The Canberra assembly and issues of mission. IBMR 15.3: 98-103.

Khalid, F. M., and O'Brien, J. 1992. Islam and ecology. New York: Cassell.

Kim, K. 2007. The Holy Spirit in the world: A global conversation. Maryknoll: Orbis.

Kirkpatrick, M. 2007. For God so loved the world: An incarnational ecology. ATR 91.2: 191-212. 
Kolbert, E. 2006. Field notes from a catastrophe: Man, nature, and climate change. New York: Bloomsbury Press.

Krueger, F. W., and Pope John Paul II. 2003. The ecological crisis is a moral crisis: A summary of pope John Paul II on environmental responsibility, Including his spiritual directions on creation care to the faithful and all society. Santa Rosa: Religious Campaign for Forest Conservation.

Kuhn, T. S. 1996. The structure of scientific revolutions. Chicago: University of Chicago Press.

Kuma, A. 1981. Jesus of the deep forest. Accra: Asempa.

LaChance, A. J., and Carrol, J. E. 1994. Embracing earth: Catholic approaches to ecology. Maryknoll: Orbis.

LaCugna, C. M. 2006. God for us: The trinity and Christian life. New York: Harper.

Ladd, G. E. 1974. The presence of the future: The eschatology of biblical realism. Grand Rapids: Eerdmans.

-----. 1993. 1993. A theology of the New Testament. Grand Rapids: Eerdmans.

Land, S. J. 1994. Pentecostal spirituality: A passion for the kingdom. JPTSup, vol. 1. Sheffield: Sheffield Academic Press.

Leakey, R. E. 1994. The origin of humankind. New York: Basic Books.

Lederle, H, and Clark, M. 1989. What is distinctive about pentecostal theology? Pretoria: University of South Africa.

------. 1991. Initial evidence and the charismatic movement: An ecumenical appraisal. In Initial evidence: Historical and biblical perspectives on the pentecostal doctrine of Spirit baptism, ed. McGee, G., 131-141. Peabody: Hendrickson.

Leopold, A. 1970. A sand county almanac. New York: Ballentine.

Lerner, K. L., and Lerner, B. W. 2006. Environmental issues: Essential primary sources. Detroit: Thomson Gale.

Liderbach, D. 1989. The numinous universe. New York: Paulist.

Lincoln, A. T. 1990. Ephesians. Word Biblical Commentary. Waco: Word.

Lindbeck, G. A. 1984. The nature of doctrine: Religion and theology in a postliberal age. Philadelphia: Westminster.

Lindberg, D. C., and Numbers, R. L. 1986. God and nature: Historical essays on the encounter between Christianity and science. Berkeley: University of California Press.

Lindsey, H. 1970. The late great planet earth. Grand Rapids: Zondervan.

Linzey, A. 1998. Animal gospel: Christian faith as though animals mattered. London: Hodder \& Staughton.

Litonjua, M. D. 2000. Pentecostalism in Latin America: Scrutinizing a sign of the times. JHLT 7.4: 26-49.

Livingston, J. C., and Fiorenza, F. S., eds. 2000. Modern Christian thought. Vol. 2. Upper Saddle River: Prentice Hall.

Lodge, D., and Hamlin, C. 2006. Beyond Lynn White: Religion, the contexts of ecology, and the flux of nature. In Religion and the new ecology, eds. Lodge, D., and Hamlin, C., 1-25. Notre Dame: Notre Dame.

Lonergan, A., and Richards, C. 1987. Thomas Berry and the new cosmology. Mystic: Twenty-Third Publications.

Lossky, V. 2005. The mystical theology of the eastern church. London: James Clarke. 
Lovelock, J. 1982. Gaia: A new look at life on earth. Oxford: Oxford University Press. -----. 2000. The ages of gaia: A biography of our living earth. Oxford: Oxford University Press.

------. 2001. Homage to Gaia: The life of an independent scientist. London: Oxford University Press.

Lovett, L. 1975. Black origins of the pentecostal movement. In aspects of pentecostalcharismatic origins, ed. Synan, V., 123-141. Plainfield: Logos International.

-----. 1987. liberation: A dual-edged sword. PNEUMA 9.2: 155-171.

-----. 2004. Kingdom beyond color: Re-examining the phenomenon of racism. Orlando: Higher Standard Publishers.

Lowdermilk, E. 1999. No longer refugees: Overcoming the outcast mentality as an obstacle to reaching the masses. In Toward healing our divisions: Reflecting on pentecostal diversity and common witness, Ed. Macchia, F., Springfield: Society for Pentecostal Studies.

Luther, M. 1960. Three treatises: An open letter to the Christian nobility. Trans. Jacobs, C., Steinhauser, A., and Lambert, A. Philadelphia: Fortress.

Lytle, M. H. 2007. The gentle subversive: Rachel Carson, Silent Spring, and the rise of the environmental Movement. Oxford: Oxford University Press.

Ma, W. Until the Spirit comes: The Spirit of God in the book of Isaiah. JSOTSup, vol. 271. Sheffield: Sheffield Academic Press.

------. 2004. The empowerment of the Spirit of God in Luke-Acts: An Old Testament perspective. In The Spirit and spirituality: Essays in honour of Russell P. Spittler, eds. Ma, W., and Menzies, R., 24, 28-40. London: T\&T Clark.

-----. 2007. The Spirit of God in creation: Lessons for Christian mission. TR 24.3: 222230.

Macchia, F. 1993. Tongues as a sign: Toward a sacramental understanding of pentecostal experience. PNEUMA 15.1: 61-76.

-----. 1993. Spirituality and social liberation: The message of the Blumharts in the light of wuerttemberg pietism. Pietist and Wesleyan Studies, vol. 4. Metuchen:

Scarecrow Press.

------. 1998. Tradition and the novum of the Spirit: A review of Clark Pinnock's Flame of Love. JPT 13: 31-48.

------. 2006, Baptized in the Spirit: A global pentecostal theology. Grand Rapids: Zondervan.

------. 2006. Pinnock's pneumatology: A pentecostal appreciation. JPT 14.2: 167-173.

-----. 2006. The kingdom and the power: Spirit baptism in pentecostal and ecumenical perspective. In Work of the Spirit, ed. Welker, M., 109-125. Grand Rapids: Eerdmans.

------. 2008. Baptized in the Spirit: Towards a global pentecostal theology. In Defining issues in pentecostalism, ed. Studebaker, S., 13-28. Eugene: Pickwick.

------. 1998. Groans too deep for words: Towards a theology of tongues as initial evidence. AJPS 1.2: 149-173.

MacDonald, G. 1976. Creation in Christ. Wheaton: H. Shaw Publishers.

Maguire, D. 1993. The moral core of judaism and Christianity: Reclaiming the revolution. Philadelphia: Fortress. 
Mahan, B, and Richesin, L. 1981. The challenge of liberation theology: A first world response. Maryknoll: Orbis.

Maitland, S. 1996. A big-enough God: A feminist's search for a joyful theology. New York: Riverhead Books.

Marshall, I. H. 1989. Luke: Historian and theologian. Grand Rapids: Zondervan.

Martin, D, and Mullen, P., eds. 1984. Strange gifts?: A guide to charismatic renewal. Oxford: Blackwell.

------. 1989. Tongues of fire: The explosion of protestantism in Latin America. Oxford: Blackwell.

-----. 2002. Pentecostalism: The world their parish. Oxford: Blackwell.

Martin, R. 2008. The unheard voice of God: A pentecostal hearing of the book of judges. Blandford Forum: Deo.

McCarty, D. 1976. Teilhard de Chardin. Makers of the Modern Theological Mind. Waco: Word Books.

McClendon, J. W. 1994. Systematic theology: Doctrine. Vol. 2. Nashville: Abingdon.

-----. 2000. Systematic theology: Witness. Vol. 3. Nashville: Abingdon.

-----. 2002. Systematic theology: Ethics. Vol. 1. Nashville: Abingdon.

McDaniel, J. B. 1990. Earth, sky, gods \& mortals: Developing an ecological spirituality. Mystic: Twenty-Third Publications.

------. 1995. With roots and wings: Christianity in an age of ecology and dialogue. Maryknoll: Orbis.

McDonagh, S. 1990. The greening of the church. Maryknoll: Orbis.

-----. 1994. Passion for the earth. Maryknoll: Orbis.

McDonnell, K, and Montague, G. 1994. Christian initiation and baptism in the Holy Spirit: Evidence from the first eight centuries. Collegeville: Liturgical Press.

-----. 1975. The Holy Spirit and power: The catholic charismatic renewal. Garden City: Doubleday.

------. 1976, Charismatic renewal and the churches. New York: Seabury.

-----. 1980. Presence, power, praise: Documents on the charismatic renewal.

Collegeville: Liturgical Press.

------ 1985. A trinitarian theology of the Holy Spirit. TS 46.2: 191-227.

------ 1996. The baptism of Jesus in the Jordan: The trinitarian and cosmic order of salvation. Collegeville: Liturgical Press.

------. 2003. The other hand of God: The Holy Spirit as the universal touch and goal. Collegeville: Liturgical Press.

McFague, S. 1966. Literature and the Christian life. New Haven: Yale University Press.

-----. 1967. Theology and the arts. TT 24.1: 93-94.

-----. 1968. Belief and disbelief in American literature. TT 25.2: 257-258.

-----. 1968. Philosophy of law. SDS 51.4, 361-447.

------. 1969. Criticism as dialogue. $C U$ 7.3: 506-509.

-----. 1970. In praise of play. $R L$ 39.2: 318-319.

------. 1971. Women's liberation and the church: The new demand for freedom in the life of the Christian church. JAAR 39.3: 401.

-----. 1972. Family, communes and utopian societies. New York: Harper \& Row.

------ 1973. Rediscovery of ethnicity: Its implications for culture and politics in America. SDS 56.1: 1-138. 
----- 1974. Parable, metaphor, and theology. JAAR 42.4: 630-645.

-----. 1975. Experience of coming to belief. TT 32.2: 159-165.

-----. 1975. Intermediary theology: In service of the hearing of God's word. CC 92.23: 625-629.

-----. 1975. Speaking in parables: A study in metaphor and theology. Philadelphia: Fortress.

------. 1976. Dark interval: Towards a theology of story. Review of Books and Religion (Vermont) 5:1.

-----. 1976. Learning for the whole person: A model from the parables of Jesus. $R L$ 45.2: 161-173.

-----. 1982. Metaphorical theology: Models of God in religious language. Minneapolis:

Fortress.

-----. 1985. Jesus's parables and the war of myths: Essays on imagination in the scriptures. JR 65.2: 271-272.

-----. 1986. Models of God: Theology for an ecological, nuclear Age. Philadelphia: Fortress.

-----. 1988. Plurality and ambiguity: Hermeneutics, religion, hope. TT 44.4: 500-503.

-----. 1989. God as mother. In Weaving the visions, eds. Plasgow, J., and Christ, C., 139150. San Francisco: Harper \& Row.

-----. 1992. A Square in the quilt: One theologian's contribution to the planetary agenda. In Spirit and nature, eds. Rockefeller, S., and Elder, J., 39-58. Boston: Beacon Press.

-----. 1993. The body of God: An ecological theology. Minneapolis: Fortress.

------ 1994. Human beings, embodiment, and our home the earth. In Reconstructing Christian theology, eds. Chopp, R., and Taylor, M., 141-169. Minneapolis: Fortress.

-----. 1997. The loving eye vs the arrogant eye: Christian critique of the western gaze on nature and the third world. ER 49.2: 185-193.

-----. 1997. Super, natural Christians: How we should love nature. Minneapolis: Fortress.

-----. 2000. An ecological christology: Does Christianity have it? In Christianity and ecology, Hessel, D., and Ruether, R., 29-45. Cambridge: Harvard University Press.

-----. 2001. Life abundant: Rethinking theology and economy for a planet in peril. Minneapolis: Fortress.

-----. 2008. A new climate for theology: God, the world, and global warming. Minneapolis: Fortress.

McGee, G. B. 2003. 'More than evangelical': The challenge of the evolving theological identity of the assemblies of God. PNEUMA 25.2: 289-300.

------., ed. 1991. Initial evidence: Historical and biblical on the pentecostal doctrine of Spirit Baptism. Peabody: Hendrickson.

McHarg, I. L. 1969. Design with nature. Garden City: Natural History Press.

McIntosh, M. A. 1998. Mystical theology: The integrity of spirituality and theology. London: Blackwell.

McKnight, S. 2005. Embracing grace: A gospel for all of us. Brewster: Paraclete. 
McQueen, L. R. 1995. Joel and the Spirit: The cry of a prophetic hermeneutic. JPTSup, vol. 8. Sheffield: Sheffield Academic Press.

Medina, N. 2008. Jürgen Moltmann and pentecostalism(S): Toward a cultural theology of the Spirit. In Love and Freedom, ed. Khan, A., 101-113. Toronto: Toronto School of Theology.

Menzies, R. P. 1991. The development of early Christian pneumatology with special reference to Luke-Acts. JSNTSup, vol. 54. Sheffield: Sheffield Academic Press.

------. 1994. Empowered for witness: The Spirit in Luke-Acts. JPTSup, vol. 6. Sheffield: Sheffield Academic.

Menzies, W. W., and Horton, S. M. 1993. Bible doctrines: A pentecostal perspective. Springfield: Logion Press.

------., and Menzies, R. P. 2000. Spirit and power: Foundations of pentecostal experience. Grand Rapids: Zondervan.

Merchant, C. 2005. Radical ecology: The search for a livable world. New York: Routledge.

------. 1989. The death of nature: Women, ecology and the scientific revolution. New York: HarperCollins.

Midgley, M. 1978. 2007. Beast and man: The roots of human nature. Ithica: Cornell University Press.

-----. 1983. Animals and why they matter. Athens: University of Georgia Press.

Miller, D., and Yamamori, Y. 2007. Global pentecostalism: The new face of Christian social engagement. Berkeley: University of California Press.

Miller, G. T. 1992. Living in the environment. Belmont: Wadsworth.

Mittelstadt, M. 2004. The Spirit and suffering in Luke-Acts: Implications for a pentecostal pneumatology. JPTSup, vol. 26. London: Continuum.

Moltmann, J, and Meeks, M. D. 1978. The open church: Invitation to a messianic lifestyle. London: SCM.

------. 1990. The way of Jesus Christ: Christology in messianic dimensions. Trans. Kohl, M. New York: Harper SanFrancisco.

-----. 1992. The Spirit of life: A universal affirmation. Trans. Kohl, M. Minneapolis: Fortress.

------. 1993. God in creation: A new theology of creation and the Spirit of God. Trans. Kohl, M. Minneapolis: Fortress.

------. 1993. The coming of God: Christian eschatology. Trans. Kohl, M. Minneapolis: Fortress.

-----. 1994. A response to my pentecostal dialogue partners. JPT 4: 59-70.

-----. 1997. Spirit of life: A universal affirmation. Trans. Kohl, M. Minneapolis: Fortress.

-----. 1997. The source of life: The Holy Spirit and the theology of life. Trans. Kohl, M. London: SCM Press.

-----. 2000. Experiences in theology: Ways and forms of Christian theology. Trans. Kohl, M. Minneapolis: Fortress Press.

-----. 2004. In the end -- the beginning: The life of hope. Trans. Kohl, M. Minneapolis: Fortress.

-----. 1979. The future of creation: Collected essays. Philadelphia: Fortress.

Montague, G. T. 1979. The Holy Spirit: Growth of a biblical tradition. Peabody:

Hendrickson. 
Moo, D. J. 2006. Nature in the new creation: New Testament eschatology and the environment. JETS 49: 449-488.

Morris, C. 2006. Things shaken - Things unshaken: Reflections on faith and terror. Werrington: Epworth.

Moule, C. F. D. 1978. The Holy Spirit. Oxford: Mowbray.

Mouw, R. 1987. Life in the Spirit in an unjust world. PNEUMA 9.2: 109-128.

Mudge, L. S. 1980. Paul Ricoeur on biblical interpretation. In Essays on biblical interpretation, ed. Ricoeur, R., 1-40. Philadelphia: Fortress.

Murphy, C. M. 1989. At home on earth: Foundations for a catholic ethic of the environment. New York: Crossroad.

Nadar, S. 2009. 'The Bible says!' Feminism, hermeneutics and neo-pentecostal challenges. JTSA 134: 131-146.

Naess, A. 1973. The shallow and the deep, long-range ecology movement: A summary. INQ 16: 95-100.

Nash, J. A. 1996. Toward the ecological reformation of Christianity. INT 50.1: 5-15.

Nash, R. F. 1989. The rights of nature: A history of environmental ethics. Madison: University of Wisconsin Press.

Nelson, D. J. 1981. For such a time as this: The story of bishop William J. Seymour and the Azusa Street revival. PhD Dissertation, University of Birmingham, UK.

Neve, L. R. 1972. Spirit of God in the Old Testament. Minneapolis: Augsburg.

Neville, R. C. 2002. Religion in late modernity. Albany: State University of New York Press.

Newbigin, L. 1953. The household of God. New York: Friendship Press.

Newman, B. 1997. Sister of wisdom: St Hildegard's theology of the feminine. Berkeley: University of California Press.

Niebuhr, R. 2001. Christ and culture. New York: Harper.

Njoku, U. J. 2007. The influence of changes in socio-economic thinking on the development of post-vatican II catholic social teaching. PT 8.2: 235-248.

Noll, M. A. 1995. The scandal of the evangelical mind. Grand Rapids: Eerdmans.

Norris, D. S. 2009. Creation revealed. In The Spirit renews the face of the earth, ed. Yong, Y., 74-92. Eugene: Pickwick.

Nothwehr, D. 1998. Mutuality: A formal norm for Christian social ethics. San Francisco: Catholic Scholars Press.

O'Connor, E. D. 1975. The hidden roots of the charismatic renewal in the catholic church. In Aspects of pentecostal-charismatic origins, ed. Synan, V., 169-191. Plainfield: Logos International.

O'Donovan, L. J. 1980. A world of grace: An introduction to the themes and foundations of Karl Rahner's theology. New York: Seabury.

O’Murchu, D. 1997. Quantum theology. New York: Crossroad.

------. 1998. Reclaiming spirituality: A new spiritual framework for today's world. New York: Crossroad.

------. 2002. Evolutionary faith: Redisovering God in our great story. Maryknoll: Orbis.

-----. 2005. Teilhard: A mystical survivor! ECO 10.1: 99-108.

Oden, T. C. 1992. Life in the Spirit. Vol. 3. San Francisco: Harper San Francisco.

Oelschlaeger, M. 1991. The idea of wilderness: Prehistory to the age of ecology. New Haven: Yale University Press. 
------ 1994. Caring for creation: An ecumenical approach to the environmental crisis. New Haven: Yale University Press.

------. 1995. Postmodern environmental ethics. Albany: SUNY Press.

Oikonomou, D., and Belopopsky, A. 1996. Orthodoxy and ecology: Resource book. Bialystok: Syndesmos the World Fellowship of Orthodox Youth.

Olson, R. E. 1999. The story of Christian theology: 20 centuries of tradition and reform. Downer's Grove: IVP.

Oord, T. J., ed. 2009. Divine grace and emerging creation: Wesleyan forays in science and theology of creation. Eugene: Pickwick.

Packer, J. I. 1984. Keep in step with the Spirit. Leicester: IVP.

Page, R. 1985. Ambiguity and the presence of God. London: SCM.

-----. God and the web of creation. London: SCM.

Palmer, J. 2001. Fifty key thinkers on the environment. London: Routledge.

Panikkar, R., and Eastham, S. 1993. The cosmotheandric experience: Emerging religious consciousness. Maryknoll: Orbis.

------. 2006. The experience of God: Icons of the mystery. Minneapolis: Fortress.

Pannenberg, W. 2004. Systematic theology. 3 vols. New York: T\&T Clark.

Parham, S. E. 1930. The life of Charles F. Parham: Founder of the apostolic faith movement. Joplin: Hunter Publishing.

Parker, S. 1996. Led by the Spirit: Toward a practical theology of pentecostal discernment and decision making. JPTSup, vol. 7. Sheffield: Sheffield.

Passmore, J. 1972. Man's responsibility for nature: Ecological problems and western traditions. London: Duckworth Press.

Pedersen, K. P. 2001. Inclusion and exclusion: Reflections on moral community and salvation. In Earth habitat, eds. Hessel, D., and Rasmussen, R., 33-52, 220-223. Minneapolis: Fortress.

Penny, J. 1997. The missionary emphasis of Lukan pneumatology. Sheffield: Sheffield Academic Press.

Peterson, E. 1992. Under the unpredictable plant: An exploration in vocational holiness. Grand Rapids: Eerdmans.

Pinches, C. R., and McDaniel, J. B. 1993. Good news for animals?: Christian approaches to animal well-being. Maryknoll: Orbis.

Pink, D. H. 2006. A whole new mind: Why right-brainers will rule the future. New York: Riverhead Books.

Pinnock, C. H. 1996. Flame of love: A theology of the Holy Spirit. Downer's Grove: IVP.

-----. 2000. Divine relationality: A pentecostal contribution to the doctrine of God. JPT 16: 3-26.

-----. 2006. Church in the power of the Holy Spirit: The promise of pentecostal ecclesiology. JPT 14.2: 147-165.

Placher, W. 1994. Narratives of a vulnerable God: Christ, theology, and scripture. Louisville: Westminster.

Plumwood, V. 1993. Feminism and the mastery of sature. New York: Routledge.

Pluss, J. 1988. Review of Geist Und Materie. EPTA 7.2: 70-72.

-----. 1993. Azusa and other myths: The long and winding road from experience to stated belief and back again. PNEUMA 15.2: 189-201. 
Poewe, K. O. 1994. Charismatic Christianity as a global culture. Columbia: University of South Carolina Press.

Polanyi, K. 1944. The great transformation. New York: Farrar \& Rinehart.

Polanyi, M. 2000. Personal knowledge: Towards a post-critical philosophy. Chicago: University of Chicago Press.

Polkinghorne, J. 1986. One world: The interaction of science and theology. Princeton: Princeton University Press.

-----. 1988. Sciece and creation: The search for understanding. London: SPCK.

------ 2001. The work of love: Creation as kenosis. Grand Rapids: Eerdmans.

------. 2007. Quantum physics and theology: An unexpected kinship. New Haven: Yale University Press.

Poloma, M. M. 1989. The assemblies of God at the crossroads: Charisma and institutional dilemmas. Knoxville: University of Tennessee Press.

Pomerville, P. 1985. The third force in missions: A pentecostal contribution to contemporary mission theology. Peabody: Hendrickson.

Price, L. 2002. Theology out of place: A theological biography of Walter J. Hollenweger. JPTSup, vol. 23. London: Sheffield Academic Press.

Primavesi, A. 2003. Gaia's gift: Earth, ourselves, and God after Copernicus. New York: Routledge.

Prime, R. 1994. Hinduism and ecology: Seeds of truth. New Delhi: Motilal Banarsidass Publishers.

Pruitt, R. M. 1995. Fundamentals of the faith. Cleveland: White Wing Publishing House.

Putnam, R. D. 2001. Bowling alone: The collapse and revival of American community. London: Simon \& Schuster.

Quebedeaux, R. 1983. The new charismatics II. New York: Harper \& Row.

Rae, E. 1994. Women, the earth, the divine. Maryknoll: Orbis.

Rahner, K. 1966. Christology within an evolutionary view of the world. In Theological investigations, vol. 5, 157-92. London: Daron, Longman, and Todd.

------. 1975. Evolution: II. Theological. In Encyclopedia of theology: A concise sacramentum mundi, ed. Rahner, K., 478-88. London: Burns and Oats.

------. 1978. Foundations of Christian faith. New York: Seabury Press.

Randour, M. L. 2000. Animal grace: Entering a spiritual relationship with our fellow creatures. Novato: New World Library.

Rasmussen, L. L. 1996. Earth community earth ethics. Maryknoll: Orbis.

Rauschenbusch, W. 2007. Christianity and the social crisis in the 21st Century: The classic that woke up the church. San Francisco: HarperSanFrancisco.

Reader, J. 1994. Local theology: Church and community in dialogue. London: SPCK.

Redekop, C. W. 2000. Creation \& the environment: An anabaptist perspective on a sustainable world. Baltimore: Johns Hopkins University Press.

Richards, R. J. 2008. The tragic sense of life: Ernst Haeckel and the struggle over evolutionary thought. Chicago: University of Chicago.

Ricoeur, P, and Wallace, M. 1995. Figuring the sacred: Religion, narrative, and imagination. Minneapolis: Fortress.

Riggs, R. 1949. The Spirit himself. Springfield: Gospel Publishing House. 
Robeck, C. M. 1983. Name and glory: The ecumenical challenge. In pastoral pentecostal-charismatic movement, ed. Hunter, H. Cleveland: Society for Pentecostal Studies.

-----. 1987. Pentecostals and the apostolic faith: Implications for ecumenism. PNEUMA 9.1: 61-84.

-----. 1991. William J. Seymour and the 'Bible evidence'. In Initial evidence: Historical and biblical perspectives on the pentecostal doctrine of Spirit Baptism, ed. McGee, G., 72-95. Peabody: Hendrickson.

------. 1993. Taking stock of pentecostalism: The personal reflections of a retiring editor. PNEUMA 15.1: 35-60.

Robinson, T., and Chatraw, J. 2006. Saving God's green earth: Rediscovering the church's responsibility to environmental stewardship (Norcross: Ampelon Publishing.

Roebuck, D. 2005. Pentecostalism at the end of the twentieth century: From poverty, promise and passion to prosperity, power and place. In Religion in the contemporary South, changes, continuities, and contexts, ed. Norman, C., 53-73. Knoxville: University of Tennessee Press.

Rogers, E. F. 1999. Sexuality and the Christian body: Their way into the triune God. Oxford: Blackwell.

-----. 2005. After the Spirit: A constructive pneumatology from resources outside the modern West. Grand Rapids: Eerdmans.

Rogers, J. B. 1973. Ecological theology: The search for an appropriate theological model. In Septuagesimo Anno, 181-202. Kampen: Uitgeversmaatschappij.

Rolston, H. 1996. The Bible and ecology. INT 50: 16-26.

Roper, D. 2007. The earth as a garden for all creatures: Lynn White forty years on. STM 15.4: $12-20$.

Rossi, V. 1990. For the transfiguration of nature: Papers from the symposium on orthodoxy and ecology. EPI 10: 7-74.

Roszak, T, Gomes, M., Kanner, E., and López, L. 1995. Ecopsychology: Restoring the earth, healing the mind. San Francisco: Sierra Club.

-----. 1970. The making of a counter culture: Reflections on the technocratic society and its youthful opposition. London: Faber.

Royal, R. 1999. The virgin and the dynamo: Use and abuse of religion in environmental debates. Grand Rapids: Eerdmans.

Ruddiman, W. F. 2007. Plows, plagues, and petroleum: How humans took control of the climate. Princeton: Princeton University Press.

Ruether, R. R. 1975. New woman, new earth: Sexist ideologies and human liberation. New York: Seabury Press.

-----. 1983. Sexism and God-talk: Toward a feminist theology. Boston: Beacon Press.

-----. 1993. Gaia and God: An ecofeminist theology of earth Healing. London: SCM.

Russell, R. J. 2008. Cosmology: From alpha to omega. Minneapolis: Fortress.

Rybarczyk, E. J. 2004. Beyond salvation: Eastern orthodoxy and classical pentecostalism on becoming like Christ. Carlisle: Paternoster.

Sanders, C. J. 1996. Saints in exile: The holiness-pentecostal experience in African American religion and culture. New York: Oxford University Press. 
Santmire, H. P. 1985. The liberation of nature : Lynn White's challenge anew." CC 102.18: 530-533.

-----. 1985. The travail of nature: The ambiguous ecological promise of Christian theology. Minneapolis: Fortress.

Savary, L. M. 2007. Teilhard de Chardin, the divine milieu explained: A spirituality for the 21st Century. New York: Paulist.

Schaeffer, F. A. 1970. Pollution and the death of man. Wheaton: Crossway Books.

Schama, S. 1995. Landscape and memory. New York: Knopf.

Schleiermacher, F. 1928. The Christian faith. Trans. Mackintosh, H. R., and Stewart, J. S. New York: Charles Scribner's Sons.

Schnackenburg, R. 1991. Ephesians: A commentary. Edinburgh: T\&T Clark.

Schumacher, E. F. 1973. Small Is beautiful. New York: Harper \& Row.

Schut, M. 2009. Coming home: Economics and ecology. ATR 91.4: 581-588.

Schweitzer, A., and Bowden, J. 2001. The quest of the historical Jesus. Minneapolis: Fortress.

Schweizer, E. 1979. What is the Holy Spirit?: A study in biblical theology. In Conflicts about the Holy Spirit, ed. Küng, H. and Moltmann, J., ix-xvii. New York: Seabury.

-----. 1980. The Holy Spirit. London: SCM.

-----. 1989. On distinguishing between spirits. ER 41.3: 406-415.

Segundo, J. 1988. An evolutionary approach to Jesus of Nazareth. Maryknoll: Orbis.

Sepulveda, J. 1988. Pentecostal theology in the context of the struggle for life. In Faith born in the struggle for life: A rereading of protestant faith in Latin America today, ed. Kirkpatrick, D., 298-318. Grand Rapids: Eerdmans.

-----. 1993. Pentecostalism and liberation theology: Two manifestations of the work of the Holy Spirit for the renewal of the church. In All together in one place:

Theological papers from the Brighton conference on world evangelization, ed. Hunter, H., and Hocken, P., 51-64. Sheffield: Sheffield Academic Press.

-----. 1998. Future perspectives for Latin American pentecostalism. IRM 87.345: 189195.

Sessions, G. 1995. Deep ecology for the twenty-first century. Boston: Shambhala.

Sheldrake, R. 1994. The rebirth of nature: The greening of science and God. Rochester: Inner Traditions.

Shelton, J. B. 1991. Mighty in word and deed: The role of the Holy Spirit in Luke-Acts. Peabody: Hendrickson.

Sheppard, G. 1984. Pentecostalism and the hermeneutics and dispensationalism: The anatomy of an uneasy relationshiop. PNEUMA 6.2: 5-34.

Shults, F. L. 2007. The philosophy of time: The turn to futurity in late modern Philosophy. ST 61.1: 47-60.

-----. 2008. Spirit and spirituality: Philosophical trends in late modern pneumatology. PNEUMA 30.2: 271-287.

Simmons, E. L. 1999. Towards a kenotic pneumatology: Quantum field theory and the theology of the cross. CTNS 19.1: 11-16.

Sirks, G. J. 1957. The cinderella of theology: The doctrine of the Holy Spirit. HTR 50.2: 77-90.

Sjorup, L. 2002. Pentecostals: the power of the powerless. $D G$ 41.1: 16-25. 
Smith, J. K. A. 1997. Scandalizing theology: A pentecostal response to Noll's scandal. PNEUMA 19: 225-238.

-----. 2008. Thinking in tongues. FT April: 27-31.

Smith, J. Z. 1978. Map is not territory: Studies in the history of religion. Chicago: University of Chicago Press.

Smith, W. C. 1991. The meaning and end of religion. Minneapolis: Fortress.

Snell, J. T. 1992. Beyond the individual and into the world: A call to participation in the larger purposes of the Spirit on the basis of pentecostal theology. PNEUMA 14.1: 43-57.

Soelle, D. 1969. The truth is concrete. London: Burns \& Oates.

Solomon, S., et. al., eds. 2007. Climate change 2007: The physical science basis: Contributions of working group I to the fourth assessment report of the Intergovernmental Panel on Climate Change. Cambridge: Cambridge University Press.

Spittler, R. P. 1988. Spirituality, pentecostal and charismatic. In Dictionary of pentecostal and charismatic movements, eds. Burgess, S.M., M. van der Maas, E., 804-805. Grand Rapids: Zondervan.

------. 1999. Corinthian spirituality. In Pentecostal currents in American protestantism, ed. Blumhofer, E., Spittler, R., and Wacker, G., 3-19. Urbana: University of Illinois Press.

Staples, R. 1991. Reasonable enthusiast: John Wesley and the rise of methodism. AUSS 29.2: 183-185.

Stern, N. H. 2007. The economics of climate change: The Stern review. Cambridge: Cambridge University Press.

Stoll, D. 1990. Is Latin America turning protestant?: The politics of evangelical growth. Berkeley: University of California Press.

Stott, J. R. W. 1964. Baptism and fullness: The work of the Holy Spirit today. Downer's Grove: IVP.

Stout, J. 1988. Ethics after Babel. Boston: Beacon Press.

Stronstad, R. 1984. The charismatic theology of St. Luke. Peabody: Hendrickson.

-----. 1995. Spirit, scripture and theology: A pentecostal perspective. Baguio City: Asia Pacific Theological Seminary Press.

------. 1999. The prophethood of all believers: A study in Luke's charismatic theology. JPTSup, vol. 16. Sheffield: Sheffield Academic Press.

Studebaker, S. M. 2003. Pentecostal soteriology and pneumatology. JPT 11.2: 248-270.

------. 2006. Integrating pneumatology and Christology: A trinitarian modification of Clark H. Pinnock's Spirit Christology. PNEUMA 28.1: 5-20.

-----. 2008. The Spirit in creation: A unified theology of grace and creation care. $Z Y$ 43.4: $943-960$

-----. 2010. Creation care as 'keeping in step with the Spirit'. In A liberating Spirit: Pentecostals and social action in North America, eds. Studebaker, S., and Wilkenson, M., 248-263. Eugene: Pickwick.

Sullivan, F. A. 1974. Baptism in the Holy Spirit: A catholic interpretation of the pentecostal experience. Rome: Gregorian University Press.

Suurmond, J. 1988. Christ king: A charismatic appeal for an ecological lifestyle. PNEUMA 10.1: 26-35. 
-----. 1995. Word and Spirit at play: Towards a charismatic theology. Grand Rapids: Eerdmans.

Swimme, B. 1985. The universe is a green dragon: A cosmic creation story. Santa Fe: Bear Press.

Synan, V. 2000. The holiness-pentecostal tradition: Charismatic movements in the twentieth century. Grand Rapids: Eerdmans.

-----. 2002. Fundamentalism. In NIDPCM, eds. Burgess, S.M., M. van der Maas, E., 324-327. Grand Rapids: Zondervan.

------., ed. 1975. Aspects of pentecostal-charismatic origins. Plainfield: Logos International.

Tallman, M. 2009. Pentecostal ecology: A theological paradigm for pentecostal environmentalism. In The Spirit renews the face of the earth, ed. Yong, A., 135154. Eugene: Pickwick.

Taylor, J. 1972. The go-between God: The Holy Spirit and the Christian mission. London: SCM, 1972.

Taylor, S. 2007. Green sisters: A spiritual ecology. Cambridge: Harvard University Press.

Teilhard de Chardin, P. 1959. The phenomenon of man. New York: Harper.

-----. 1965. Hymn of the universe. New York: Harper \& Row.

-----. 1966. Man's place in nature. New York: Harper \& Row.

-----. 2004. The divine milieu. Portland: Sussex Academic.

Tickle, P. 1997. God-talk in America. New York: Crossroad.

Tillich, P., and Kimball, R. 1959. Theology of culture. New York: Oxford University Press.

Toynbee, A. 1974. The religious background of the present environmental crisis. In Ecology and religion in history, eds. Spring, D., and Spring, E., 137-149. New York: Harper and Row.

Tracy, D. W. 1981. The analogical imagination: Christian theology and the culture of pluralism. New York: Crossroad.

Trible, P. 1984. Texts of terror: Literary-feminist readings of biblical narratives. Overtures to Biblical Theology, vol. 13. Philadelphia: Fortress.

Troeltsch, E. 1960. The social teaching of the Christian churches. Trans. Wyon, O. 2 vols. New York: Harper and Row.

Truesdale, A. 1994. Last things first: The impact of eschatology on ecology. PSCF 46.2: 116-122.

Tucker, G. M. 1997. Rain on a land where no one lives: The hebrew Bible and the environment. JBL 116.1: 3-17.

Tucker, M., and Grim, J. 1994. Worldviews and ecology: Religion, philosophy, and the environment. Maryknoll: Orbis.

------., and Grim, J. 1997-2003. Religions of the world and ecology. 9 vols. Cambridge: Harvard University Center for the Study of World Religions.

Turekian, K. K. 1996. Global environmental change: Past, present, and future. Upper Saddle River: Prentice Hall.

Turner, M. 1996. Power from on high: The Spirit in Israel's restoration and witness in Luke-Acts. JPTSup, vol. 9. Sheffield: Sheffield Academic Press. 
Udall, S. L. 1991. The quiet crisis and the next generation. Layton: Gibbs M. Smith Publishers.

Valentin, B. 2006. New horizons in hispanic/latino theology. Cleveland: Pilgrim Press.

Vest, L. 1994. Spiritual balance: Reclaiming the promise. Cleveland: Pathway.

Villafañe, E. 1993. The liberating Spirit: Toward an hispanic American pentecostal social ethic. Grand Rapids: Eerdmans.

------. 1996. The politics of the Spirit: Reflections on a theology of social transformation for the twenty-first century. PNEUMA 18.2: 161-170.

Volf, M. 1987. Human work, divine Spirit, and new creation: Toward a pneumatological understanding of work. PNEUMA 9.2: 173-193.

------. 1989. Materiality of salvation: An investigation in the soteriologies of liberation and pentecostal theologies. JES 26.3: 447-467.

------. 1990. On loving with hope-eschatology and social responsibility. TR 7.3: 28-31.

-----. 1991. Work in the Spirit: Toward a theology of work. Eugene: Wipf and Stock.

-----. 1993. A rhythm of adoration and action. In All together in one place: Theological papers from the Brighton conference on world evangelization, ed. Hunter, H., and Hocken, P., 38-45. Sheffield: Sheffield Academic Press.

------. 1996. Exclusion and embrace: A theological exploration of identity, otherness, and reconciliation. Nashville: Abingdon.

------. 1998. After our likeness: The church as the image of the Trinity. Grand Rapids: Eerdmans.

------. 2000. The final reconciliation: Reflections on a social dimension of the eschatological transition. MT 60.1: 91-113.

------. 2005. God at work. $W W$ 25.4: 381-393.

Von Soden, H., ed. 1893. Hand-Kommentar zum zeuen testament: Die briefe an die kolosser, epheser, philemon: Die pastoralbriefe. Vol. 3. Freiburg: Mohr.

Wacker, G. 2003. Heaven below: Early pentecostals and American culture. Cambridge: Harvard University Press.

Waddell, R. 2009. Revelation and the (new) creation: A prolegomenon on the apocalypse, science, and creation. In The Spirit renews the face of the earth, ed. Yong, A., 30-50. Eugene: Pickwick.

Wall, A. 1995. Christianity in the non-western world: A study in the serial nature of Christian expansion. SWC 1.1: 1-25.

Wallace, M. I. 1990. The second naiveté: Barth, Ricoeur, and the new Yale theology. Macon: Mercer University Press.

-----. 1993. The wild bird who heals: recovering the Spirit in nature. TT 50.1: 13-28.

-----. 1996. Fragments of the Spirit: Nature, violence, and the renewal of creation. New York: Continuum.

------. 2000. From phenomenology to scripture? Paul Ricoeur's hermeneutical philosophy of religion. MT 16.3: 301-313.

------. 2000. The green face of God: Christianity in an age of ecocide. CRC 50.3: 310331.

-----. 2000. The wounded Spirit as the basis for hope in an age of radical ecology. In Christianity and ecology, ed. Hessel, D., and Ruether, R., 51-72. Cambridge: Harvard University Press. 
-----. 2005. Finding God in the singing river: Christianity, Spirit, nature. Philadelphia: Fortress.

------., and Smith, T., eds. 1994. Curing violence. Sonoma: Polebridge Press.

Walls, A. F. 2000. Of ivory towers and ashrams: Some reflections on theological scholarship in Africa. JACT 3.1: 1-4.

Wan, Y. T. 2007. The Spirit of your father: Suggestions for a fuller pentecostal pneumatology with accompanying pastoral implications. AJPS 10.2: 219-228.

Ward, P. D. 2008. Under a green sky: Global warming, the mass extinctions of the past, and what they can tell us about our future. New York: Smithsonian Books.

Warrington, K. 2005. Discovering the Holy Spirit in the New Testament. Peabody: Hendrickson.

-----. 2008. Pentecostal theology: A theology of encounter. New York: T\&T Clark.

Weaver, D. 1997. Keeping salvation ethical: Mennonite and amish atonement theology in the 19th Century. Scottdale: Herald Press.

Weber, M. 2002. The protestant work ethic and the Spirit of capitalism. New York: Penguin.

Weil, S. 1951. Waiting for God. New York: Putnam.

Weiss, J. 1970. Earliest Christianity: A history of the period A.D. 30-150. Gloucester: Peter Smith.

Welker, M. 1994. God the Spirit. Minneapolis: Fortress.

-----. 2006. The work of the Spirit: Pneumatology and pentecostalism. Grand Rapids: Eerdmans.

Wenk, M. 2002. The Holy Spirit as transforming power within a society: Pneumatological spirituality and its political/social relevance for Western Europe. JPT 11.1: 130-142.

Wenz, P. 1997. Environmentalism and human oppression. In The ecological community, ed. Gottlieb, R., 3-21. New York: Routledge.

Westerhoff, J. H. 1976. Will our children have faith? Minneapolis: Seabury.

White, L. 1967. The historical roots of our ecological crisis. Science 155: 1203-7.

Whitehead, A. N. 2004. The concept of nature. Amherst: Prometheus Books.

Wilber, K. 2001. A theory of everything: An integral vision for business, politics, science, and spirituality. Boston: Shambhala.

Wilder, A. N. 1976. Theopoetic. Philadelphia: Fortress.

Wilkenson, M., and Studebaker, S., eds. 2010. A liberating Spirit: Pentecostals and social action in North America, eds. Alexander, P., and Beaman, J., Pentecostals, Peacemaking, and Social Justice Series. Eugene: Pickwick.

Williams, J. R. 1972. The pentecostal reality. Plainfield: Logos International.

-----. 1996. Renewal theology: Systematic theology from a charismatic perspective. Grand Rapids: Zondervan.

Wink, W. 1984. Naming the powers: The language of power in the New Testament. Minneapolis: Fortress.

-----. 1986. Unmasking the powers: The invisible forces that determine human existence. Minneapolis: Fortress.

-----. 1992. Engaging the powers: Discernment and resistance in a world of domination. Minneapolis: Fortress. 
Wren, B. 1989. What language shall I borrow? God-talk in worship: A male response to feminist theology. London: SCM.

Wright, N. T. 1992. The New Testament and the people of God. Minneapolis: Fortress.

Yong, A. 1997. Oneness and the trinity: The theological and ecumenical implications of creatio ex nihilo for an intra-pentecostal dispute. PNEUMA 19.1: 81-107.

------. 1999. Whither systematic theology?: A systematician chimes in on a scandalous conversation. PNEUMA 21: 85-93.

-----. 2000. On divine presence and divine agency: Toward a foundational pneumatology. AJPS 3.2: 167-188.

------. 2000. Discerning the Spirit(S): A pentecostal-charismatic contribution to Christian theology of religions. JPTSup, vol. 20. Sheffield: Sheffield Academic Press.

------. 2002. Beyond the impasse: Toward a pneumatological theology of religions. Grand Rapids: Baker Academic.

-----. 2002. Spirit-Word-Community: Theological hermeneutics in trinitarian perspective. Burlington: Ashgate.

------. 2003. A theology of the third article?: Hegel and the contemporary enterprise in first philosophy and first Theology. In Semper reformandum: Studies in honour of Clark H. Pinnock, eds. Porter, S., and Cross, A., 208-31. Carlisle: Paternoster.

------. 2005. Academic glossalalia: Pentecostal scholarship, multi-disciplinarity, and the science-religion conversation. JPT 14.1: 61-80.

------. 2005. The Spirit and creation: Possibilities and challenges for a dialogue between pentecostal theology and the sciences. JEPTA 25: 82-110.

------. 2005. The Spirit poured out on all flesh: Pentecostalism and the possibility of global theology. Grand Rapids: Baker Academic.

------. 2006. Rûach, the primordial chaos, and the breath of life: Emergence theory and the creation narratives in pneumatological perspective. In The work of the Spirit: Pneumatology and pentecostalism, ed. Welker, M., 183-204. Grand Rapids: Eerdmans.

-----. 2007. Theology and down syndrome: Reimagining disability in late modernity. Waco: Baylor University Press.

------. 2009. The Spirit renews the face of the earth: Pentecostal forays in science and theology of creation, ed. Amos Yong. Eugene: Pickwick.

Yordy, L. R. 2008. Green witness: Ecology, ethics, and the kingdom of God. Eugene: Cascade Books.

Yun, K. D. 2003. Baptism in the Holy Spirit: An ecumenical theology of Spirit baptism. Lanham: University Press of America.

Zencey, E. 1996. The rootless professors. In Rooted in the land: Essays on community and place, eds. Jackson, W., and Vitek, W., 15-20. New Haven: Yale University Press.

Zizioulas, J. 1989. Preserving God's creation: Three lectures on theology and ecology. KTR 12: 1-5, 41-45.

-----. 2004. Being as communion: Studies in personhood and the church. London: Darton Longman \& Todd.

-----. 2006. Communion and otherness: Further studies in personhood and the church. London: T\&T Clark. 


\section{UNIVERSITYOF BIRMINGHAM}

\section{University of Birmingham Research Archive e-theses repository}

This unpublished thesis/dissertation is copyright of the author and/or third parties. The intellectual property rights of the author or third parties in respect of this work are as defined by The Copyright Designs and Patents Act 1988 or as modified by any successor legislation.

Any use made of information contained in this thesis/dissertation must be in accordance with that legislation and must be properly acknowledged. Further distribution or reproduction in any format is prohibited without the permission of the copyright holder. 